\title{
Ruthenium(II)-Catalyzed C-H Arylations of Arenes
}

\author{
Dissertation \\ zur Erlangung des mathematisch-naturwissenschaftlichen Doktorgrades \\ "Doctor rerum naturalium"
}

der Georg-August-Universität Göttingen

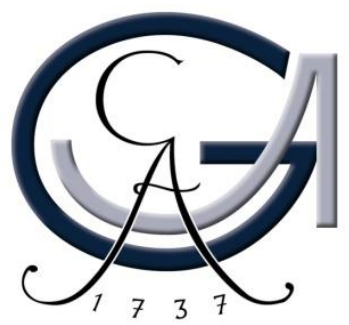

im Promotionsprogramm

der Georg-August University School of Science (GAUSS)

vorgelegt von

Jonathan Hubrich

aus

Bremen

Göttingen, 2016 



\section{Erklärung}

Ich versichere, dass ich die vorliegende Dissertation in der Zeit von November 2012 bis September 2016 am

Institut für Organische und Biomolekulare Chemie der Georg-August-Universität Göttingen

auf Anregung und unter Anleitung von

Herrn Prof. Dr. Lutz Ackermann

selbständig durchgeführt und keine anderen als die angegebenen Hilfsmittel und Quellen verwendet habe.

Göttingen, den 19.08.2016

Jonathan Hubrich

1. Gutachter: Prof. Dr. Lutz Ackermann

2. Gutachter: Dr. Alexander Breder

Tag der mündlichen Prüfung: 30.09.2016 



\section{Betreuungsausschuss:}

Prof. Dr. Lutz Ackermann, Institut für Organische und Biomolekulare Chemie

Dr. Alexander Breder, Institut für Organische und Biomolekulare Chemie

\section{Mitglieder der Prüfungskommission:}

Referent: Prof. Dr. Lutz Ackermann, Institut für Organische und Biomolekulare Chemie Korreferent: Dr. Alexander Breder, Institut für Organische und Biomolekulare Chemie

Weitere Mitglieder der Prüfungskommission:

Prof. Dr. Manuel Alcarazo, Institut für Organische und Biomolekulare Chemie

Prof. Dr. Dietmar Stalke, Institut für Anorganische Chemie

Dr. Shoubhik Das, Institut für Organische und Biomolekulare Chemie

Dr. Franziska Thomas, Institut für Organische und Biomolekulare Chemie 



\section{Contents}

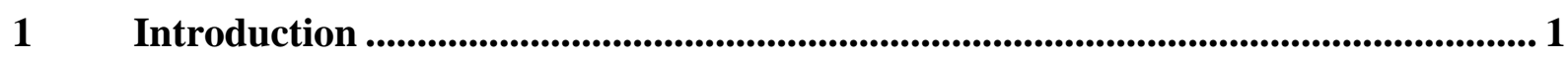

1.1 Transition metal-catalyzed $\mathrm{C}-\mathrm{H}$ activation/ $\mathrm{C}-\mathrm{C}$ formation ..................................... 1

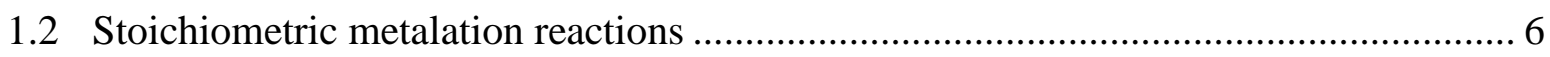

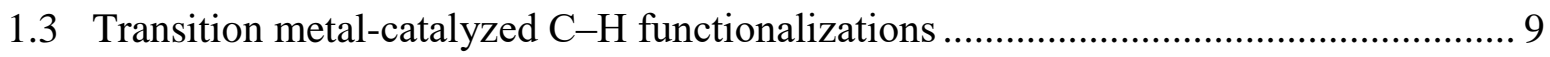

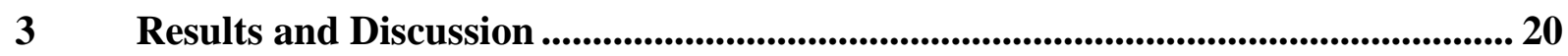

3.1 Ruthenium(II)-catalyzed C-H arylation of anilides with boronic acids,

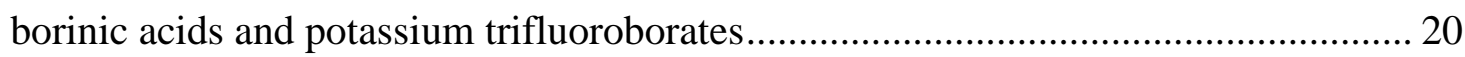

3.1.1 Optimization of $\mathrm{C}-\mathrm{H}$ arylation of acetanilide with phenylboronic acids ......... 20

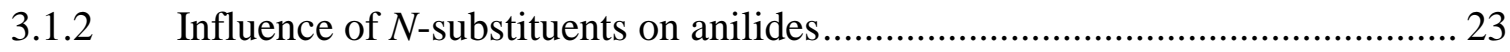

3.1.3 Scope of $\mathrm{C}-\mathrm{H}$ arylation of acetanilides with boron-based arylating reagents .. 24

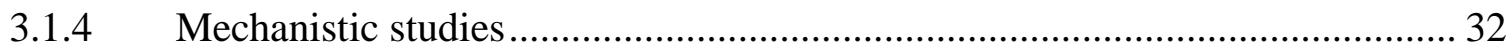

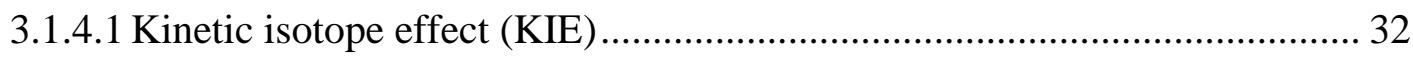

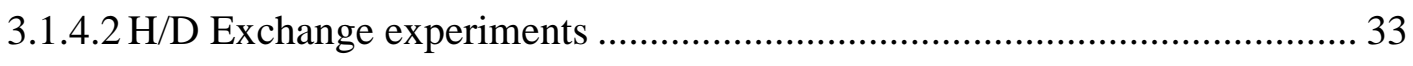

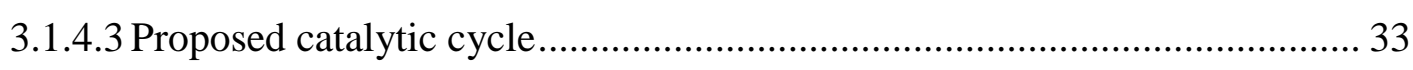

3.2 Ruthenium(II)-catalyzed C-H arylation of azoarenes by carboxylate assistance ........ 35

3.2.1 Optimization of $\mathrm{C}-\mathrm{H}$ arylation of azoarene 13a with aryl bromide 52a .......... 35

3.2.2 Scope of $\mathrm{C}-\mathrm{H}$ arylation of azoarenes with (hetero)aryl halides ....................... 38

3.2.3 One-pot synthesis for expedient access to ortho-arylated anilines ................... 46

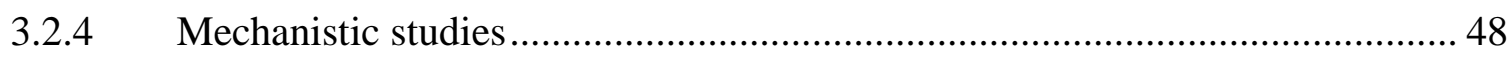

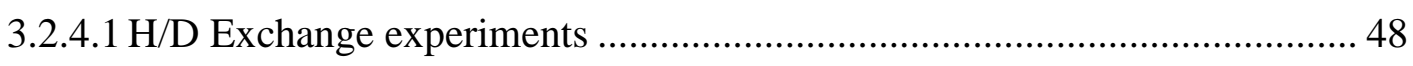

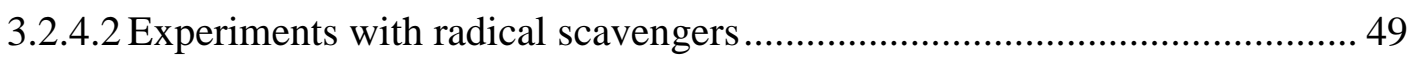

3.2.4.3 Hammett plot analysis.............................................................................. 50

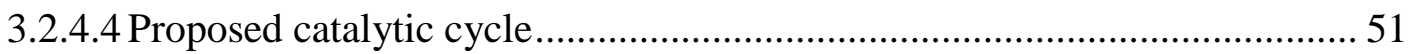

3.3 Ruthenium(II)-catalyzed $\mathrm{C}-\mathrm{H}$ arylation of 5-aryl- $1 \mathrm{H}$-tetrazoles ................................ 53

3.3.1 Optimization of $\mathrm{C}-\mathrm{H}$ arylation of $1 \mathrm{H}$-tetrazole $\mathbf{6 8 \mathbf { a }}$ with aryl chloride 59a $\ldots . .53$

3.3.2 Scope of C-H arylation of 5-aryl-1H-tetrazole with

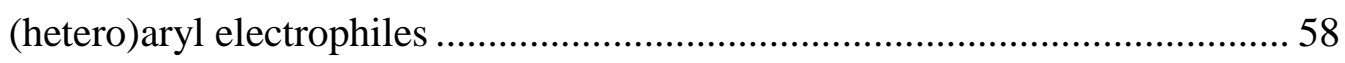

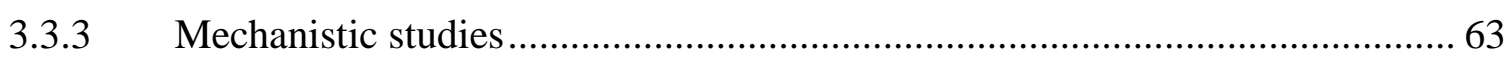

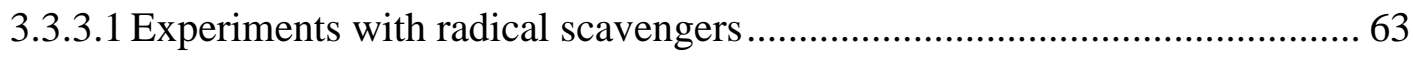




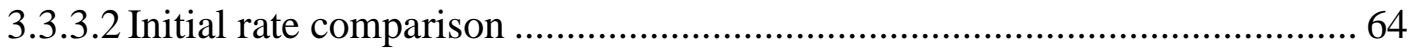

3.3.3.3 Comparison of the kinetic reaction profile …............................................ 65

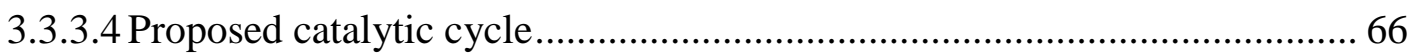

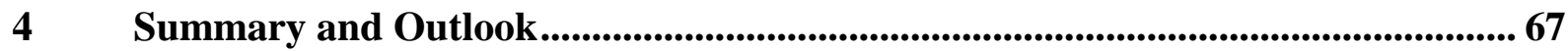

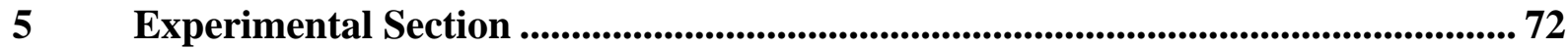

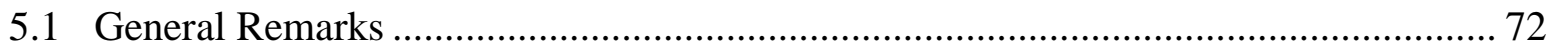

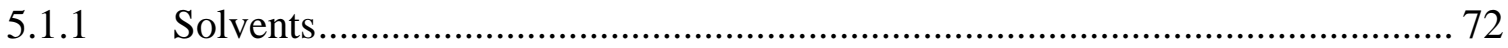

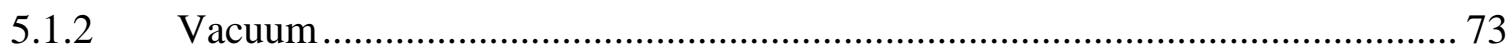

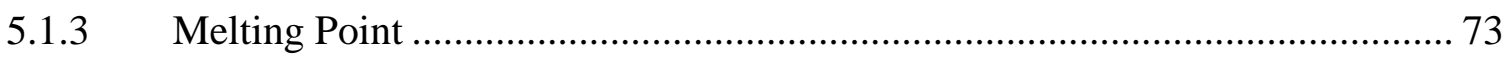

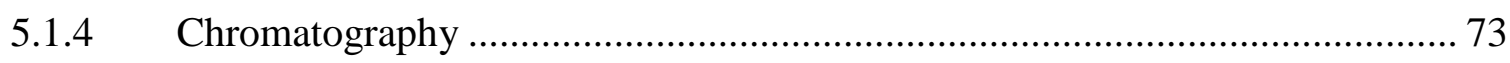

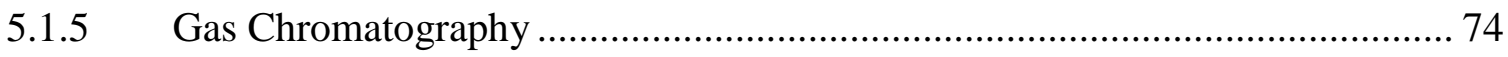

5.1.6 Nuclear Magnetic Resonance Spectroscopy ................................................ 74

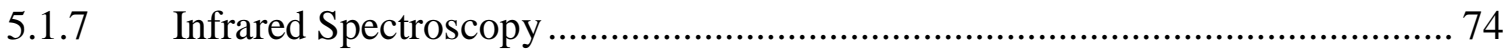

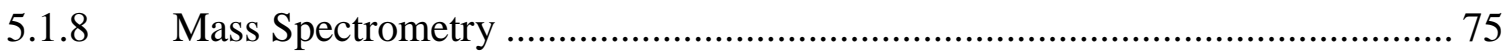

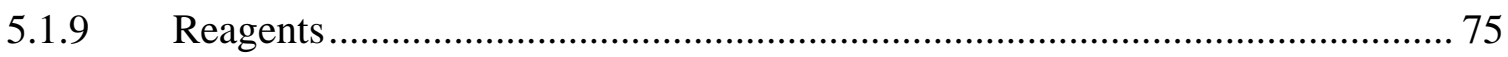

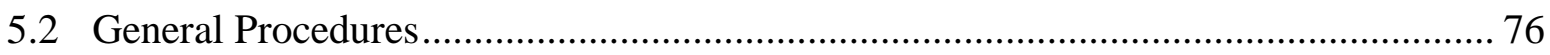

5.2.1 General Procedure A: Ruthenium(II)-catalyzed C-H-arylation of

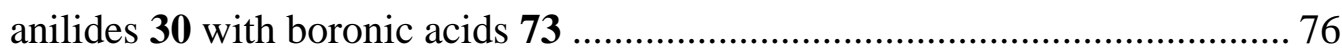

5.2.2 General Procedure B: Ruthenium(II)-catalyzed C-H-arylation of

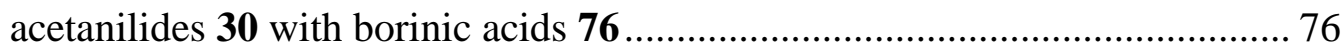

5.2.3 General Procedure C: Ruthenium(II)-catalyzed C-H-arylation of acetanilides $\mathbf{3 0}$ with potassium trifluoroborates $\mathbf{7 7}$...................................... 76

5.2.4 General Procedure D: Ruthenium(II)-catalyzed C-H-arylation of

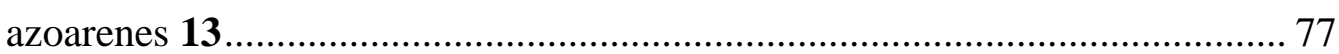

5.2.5 General Procedure E: One-pot synthesis of ortho-arylated anilines 34.......... 77

5.2.6 General Procedure F: Ruthenium(II)-catalyzed C-H arylation of

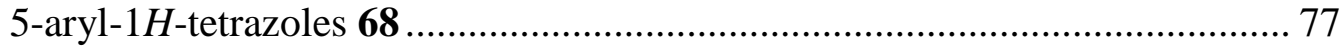

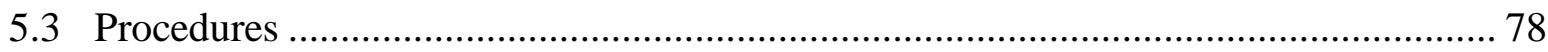

5.3.1 Procedure G: Kinetic isotope effect (KIE) study of acetanilide (30a)

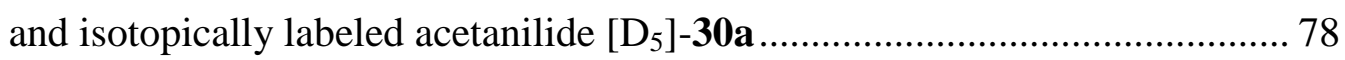

5.3.2 Procedure H: H/D-Exchange experiments of acetanilide 301......................... 80

5.3.3 Procedure I: H/D-Exchange experiments of azoarene 13 ............................. 80 
5.3.4 Procedure J: Experiments with radical scavengers for azoarene 13f. 81

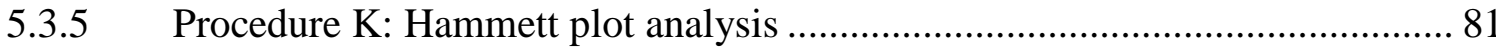

5.3.6 Procedure L: Experiments with radical scavengers for tetrazole 68a 82

5.3.7 Procedure M: Initial rate acceleration of formation of tetrazole 69aa

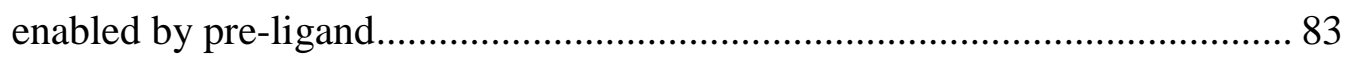

5.3.8 Procedure N: Kinetic reaction profile of formation of tetrazole 69aa.............. 84

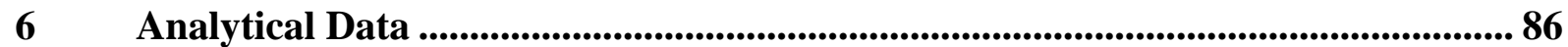

$7 \quad$ References 164 


\section{Abbreviations}

Ac

acetyl

Ad

adamantyl

Alk

alkyl

$\mathrm{Ar}$

aryl

ARB

Angiotension Receptor Blocker

ASTM

American Society for Testing and Materials

BHT

butylated hydroxytoluene

$\mathrm{Bn}$

benzyl

$n$-Bu

n-butyl

$t$ - $\mathrm{Bu}$

tert-butyl

calcd.

calculated

cat.

catalytic

CMD

concerted metalation-deprotonation

COSY correlated spectroscopy

d

doublet

$\delta$

chemical shift

DFT density function theory

DG directing group

Ed. editor

EI electron ionization

equiv equivalents

ESI electronspray ionization

Et ethyl

ET electron transfer

$\mathrm{eV} \quad$ electron volt

FT Fourier transform

g gram

GC gas chromatography

h hour

HASPO heteroatom substituted secondary phosphine oxide

HMBC heteronuclear multiple bond correlation

HRMS high resolution mass spectrometry 


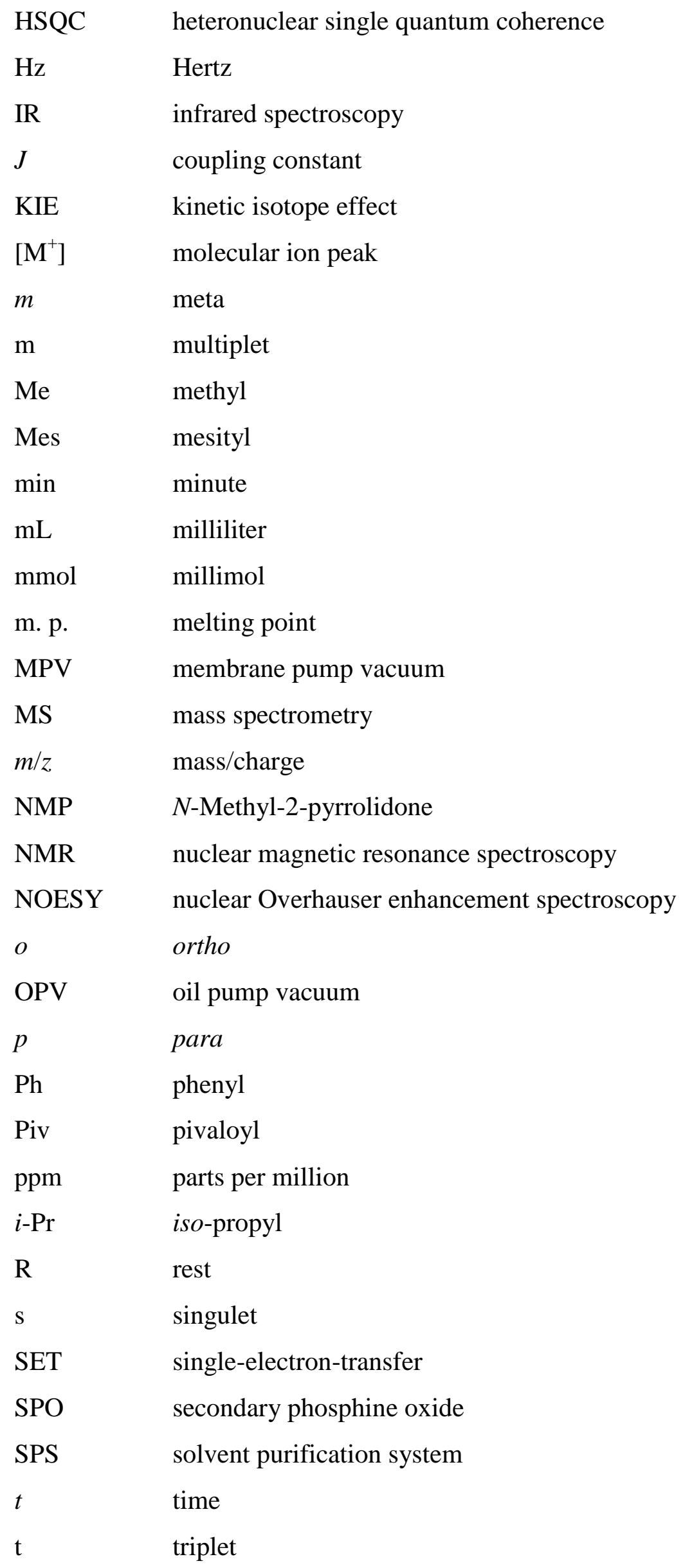


TEMPO 2,2,6,6-tetramethylpiperidine 1-oxyl

Tf triflyl

TLC thin layer chromatography

TM transition metal

UV ultraviolet 


\section{Introduction}

\subsection{Transition metal-catalyzed $\mathrm{C}-\mathrm{H}$ activation/C-C formation}

One of the fundamental demands in academic and industrial chemical research areas is to devise competitive solutions for expedient access to important compounds in material and life sciences. ${ }^{[1-4]}$ In this context, the design of novel strategies to construct $\mathrm{C}-\mathrm{C}$ bonds for the ideal synthesis of bi(hetero)aryls, which are a key molecular framework found in relevant bioactive compounds, has received considerable attention from the organic synthesis community. ${ }^{[5-14]}$ A representative set of economically valuable agrochemicals and pharmaceuticals containing bi(hetero)aryl units as core structures are illustrated in Figures 1 and 2. ${ }^{[6,15-19]}$

Classical methods for constructing bi(hetero)aryls involve reactions such as the Ullmann-type coupling, ${ }^{[20,21]}$ the Scholl reaction ${ }^{[22]}$ and the Gomberg-Bachmann reaction ${ }^{[23]}$ typically use harsh conditions, which are often not broadly applicable and can produce unsatisfactory yields.

For this reason, more efficient and selective transition metal-catalyzed cross-coupling reactions were developed. Palladium catalysis in particular has emerged as an indispensable tool for the synthesis of bi(hetero)aryl structures, becoming the method of choice for academic and industrial applications. ${ }^{[14]}$ The huge contribution of palladium-catalyzed crosscoupling reactions was highlighted by the award of the Nobel Prize in Chemistry in 2010 for Akira Suzuki, Ei-ichi Negishi and Richard F. Heck. ${ }^{[24]}$

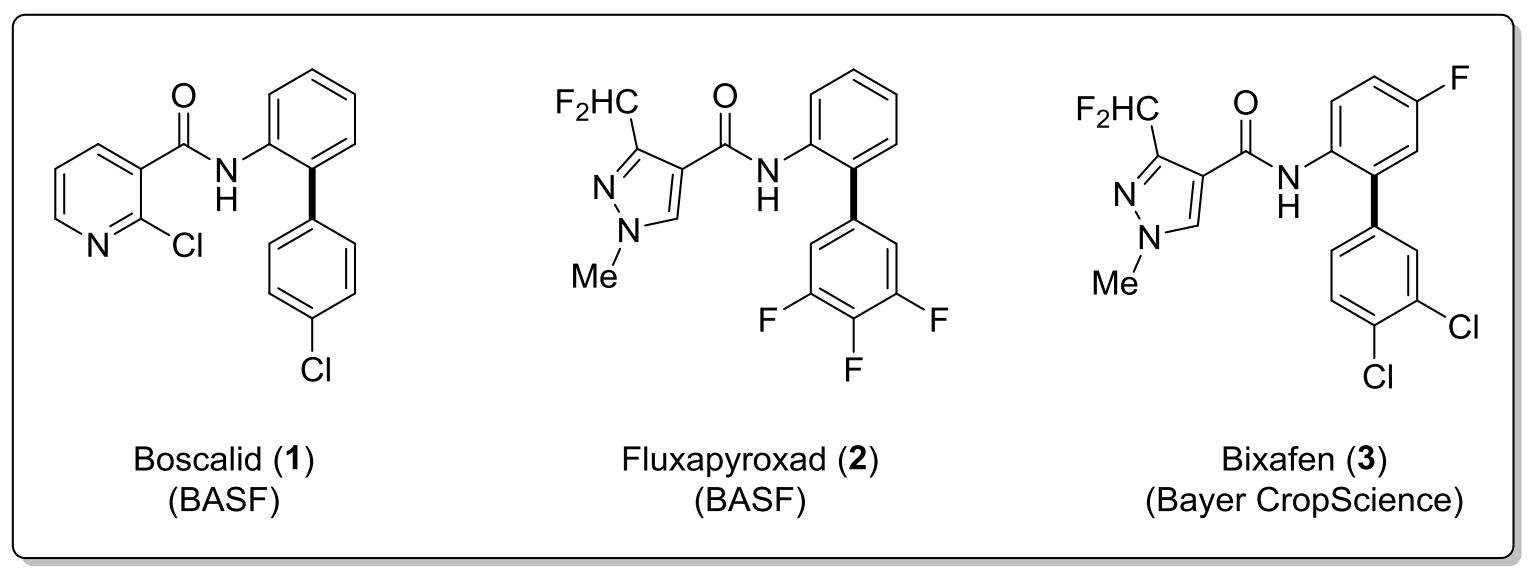

Figure 1: Selected bioactive bi(hetero)aryls present in top-selling agrochemicals. 


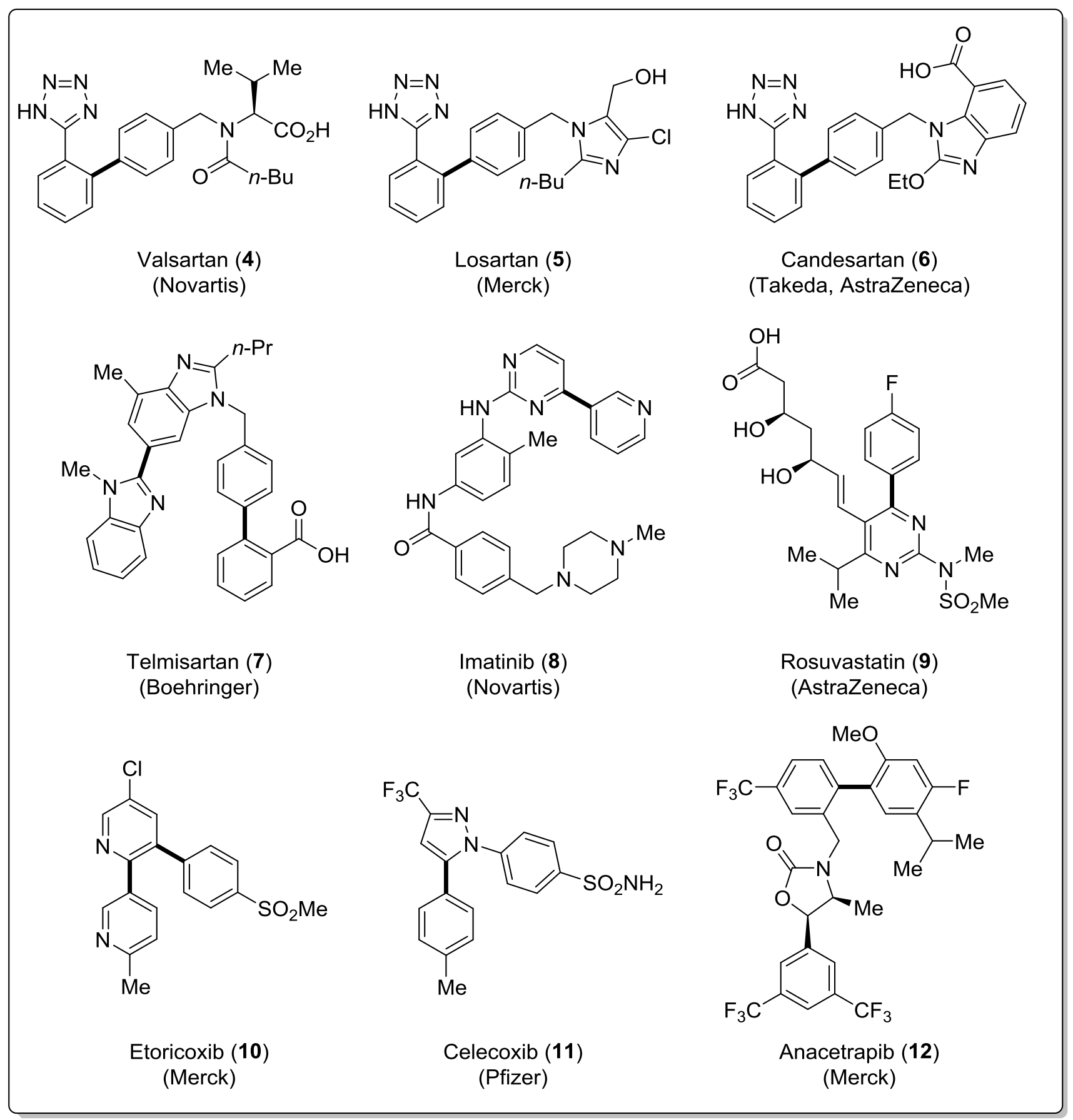

Figure 2: Selected bioactive bi(hetero)aryls present in top-selling pharmaceuticals.

Despite these advances, cross-coupling processes show a fundamental drawback as both coupling partners have to be prefunctionalized, typically from the corresponding simple arene. ${ }^{[6]}$ Generally, one partner is an unavailable or expensive organometallic compound as the aryl nucleophile, the other is an organic (pseudo)halide as the aryl electrophile $(\mathrm{C}-\mathrm{M} / \mathrm{C}-\mathrm{X}$ coupling, $\mathrm{M}=$ metal), which are found in the Kumada-Tamao-Corriu, Negishi, MigitaKosugi-Stille, Suzuki-Miyaura and Hiyama cross-coupling reactions (Scheme 1a). ${ }^{[9,14]}$ One solution to this problem is to directly modify $\mathrm{C}-\mathrm{H}$ bonds, the simplest and most common 
structural motifs in organic compounds. ${ }^{[6,15]}$ In this respect, a more attractive strategy uses an otherwise inert $\mathrm{C}-\mathrm{H}$ bond as a latent functional group to avoid substrate prefunctionalization, thus enhancing the step-economy and reducing the waste formation of a process, resulting in an advanced economical and environmentally friendly alternative. ${ }^{[6,15,16]}$ An improvement to decrease the number of preactivated starting materials was realized via oxidative direct arylations with organometallic reagents (Scheme 1b). ${ }^{[6,25-28]}$ Oxidative cross-dehydrogenative coupling (CDC) of two non-prefuntionalized arenes is the most attractive method (Scheme 1c), unfortunately, at this stage it remains difficult to control the chemo- and regioselectivity ${ }^{[6,29-33]}$ In addition, stoichiometric terminal oxidants are usually required in addition to metal salts and an overstoichiometric quantity of the arene is necessary. ${ }^{[6,7,15]}$ Therefore, a more synthetically useful approach is represented by direct $\mathrm{C}-\mathrm{H}$ bond transformation with aryl (pseudo)halides as coupling partner (Scheme 1d). ${ }^{[5-13,15-17,34]}$

(a) traditional cross-coupling

$$
\begin{aligned}
& \text { Ar } \\
& M=M g \quad(X) \quad \text { (Kumada-Tamao-Corriu) } \\
& \text { Zn (X) (Negishi) } \\
& \mathrm{Sn} \quad(\mathbf{X}) \text { (Migita-Kosugi-Stille) } \\
& \text { B (X) (Suzuki-Miyaura) } \\
& \mathrm{Si} \quad(\mathbf{X}) \text { (Hiyama) } \\
& X=(\text { pseudo)halides }
\end{aligned}
$$

(b) oxidative direct arylation

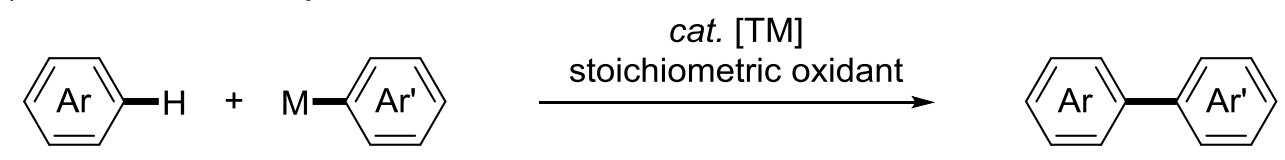

(c) oxidative cross-dehydrogenative arylation

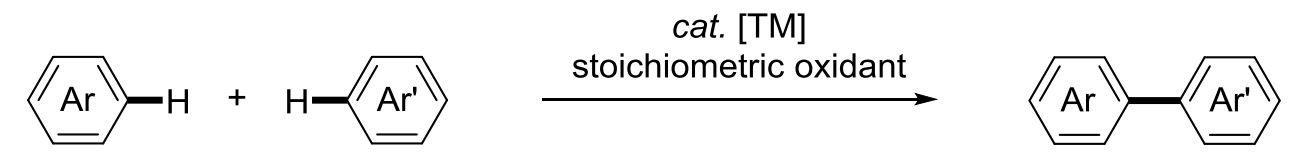

(d) C-H arylation with aryl (pseudo)halides

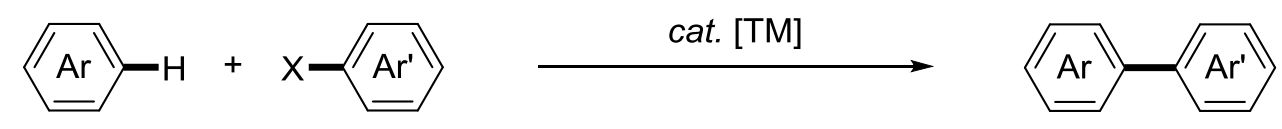

Scheme 1: Strategies for transition metal-catalyzed $\mathrm{C}\left(\mathrm{sp}^{2}\right)-\mathrm{C}\left(\mathrm{sp}^{2}\right)$ bond formation:

(a) traditional cross-coupling and (b-d) $\mathrm{C}-\mathrm{H}$ functionalization. 
Different modes of the mechanisms for the key $\mathrm{C}-\mathrm{H}$ metalation are summarized in Scheme 2: (a) Oxidative addition with electron-rich late transition metals, (b) $\sigma$-bond metathesis with early transition metals, (c) electrophilic substitution with electron-deficient late transition metals and (d) base-assisted metalation with, for instance, secondary phosphine oxides (SPOs) or carboxylates acting as an internal base. ${ }^{[7,13,35,36]}$ It should be mentioned that the exact mechanism for any given example depends on the nature of the transition metal and ligand, as well as the base and solvent. ${ }^{[13,35]}$

(a) oxidative addition

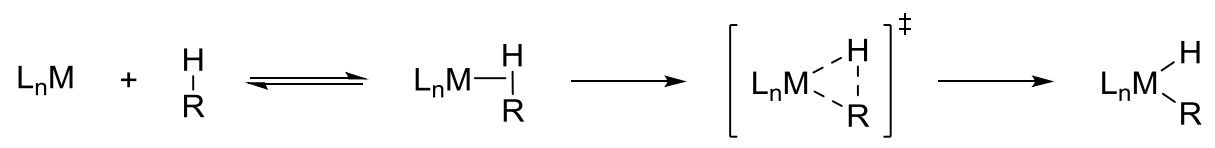

(b) $\sigma$-bond metathesis

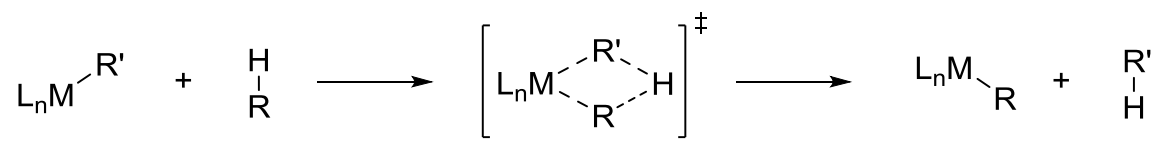

(c) electrophilic substitution

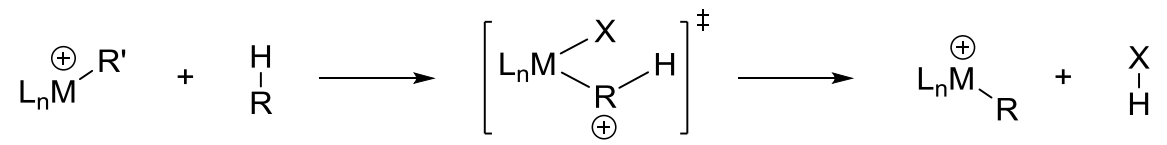

(d) base-assisted metalation

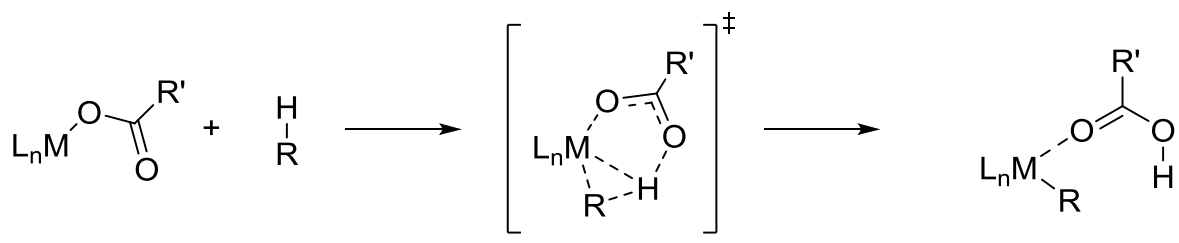

Scheme 2: Different mechanisms for $\mathrm{C}-\mathrm{H}$ metalation.

A key challenge in $\mathrm{C}-\mathrm{H}$ bond activation relates to achieving regioselective intra- or intermolecular direct arylation, due to the prevalence of $\mathrm{C}-\mathrm{H}$ bonds in organic molecules possessing comparable dissociation energies. ${ }^{[9,13,15]}$ Several strategies currently exist to control the site-selective functionalization of specific $\mathrm{C}-\mathrm{H}$ bonds (Scheme 3). ${ }^{[6,37,38]}$ Intramolecular direct arylations apply tethered reacting groups to decrease the number of potent $\mathrm{C}-\mathrm{H}$ bonds in a system to improve the site-selectivity (Scheme 3a). ${ }^{[6,13]}$ 
Another strategy for intermolecular direct arylations (Scheme 3b) based on compounds containing Lewis-basic directing groups, which coordinate to the transition metal to ensure the approximation to a specific $\mathrm{C}-\mathrm{H}$ bond, providing the cyclometalated species (Scheme 3i). ${ }^{[6,13,37,38]}$ Additionally, the steric properties of the substrate affect the $\mathrm{C}-\mathrm{H}$ functionalization, often causing the reaction to occur at the less-hindered $\mathrm{C}-\mathrm{H}$ bond. From a synthetic point of view, it is highly important to remove or convert the directing group after the desired transformation into other functionalities for further postsynthetic goals. ${ }^{[39-41]}$ An alternative concept for intermolecular direct arylations (Scheme 3b) is the influence of the electronic nature of the arene, wherein the differently electronically activated $\mathrm{C}-\mathrm{H}$ bonds rely on the inherent reactivity of the heteroarene (Scheme $3 i i) .{ }^{[6,37,38]}$

(a) Intramolecular direct arylation

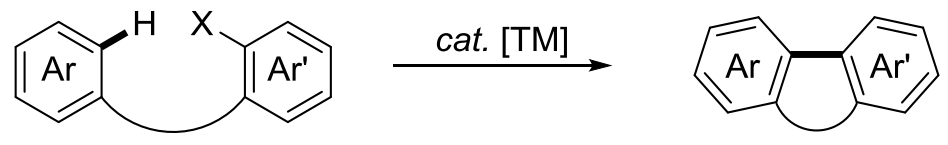

(b) intermolecular direct arylation

(i) Lewis-basic directing group

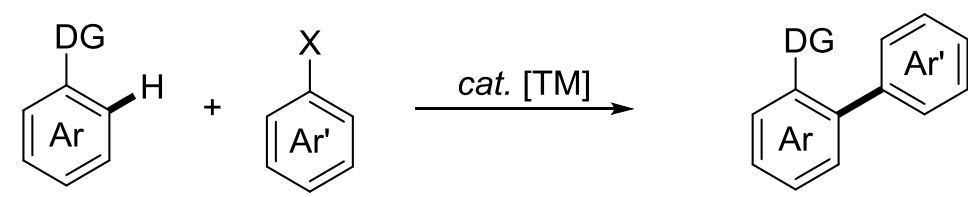

(ii) electronic nature of the substrate

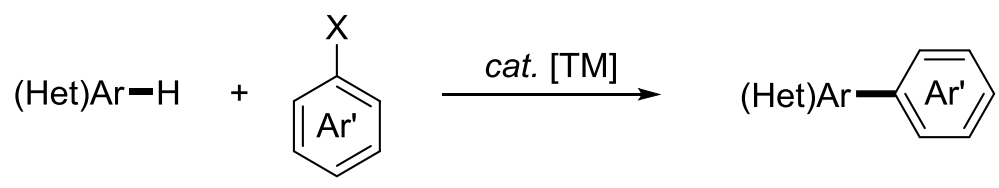

Scheme 3: Concepts to control the positional selectivity of the $\mathrm{C}-\mathrm{H}$ functionalization.

In the following sections relevant contributions for $\mathrm{C}-\mathrm{H}$ bond activation chemistry are represented, with the main focus on transition metal-catalyzed direct $\mathrm{C}-\mathrm{H}$ arylations, including significant mechanistic insights. 


\subsection{Stoichiometric metalation reactions}

Coordination chemistry is of primary mechanistic significance for insights into potential reactivities and selectivities, in order to explore novel chemical transformations. ${ }^{[6]} \mathrm{A}$ pioneering study for the stoichiometric metalation of specific $\mathrm{C}-\mathrm{H}$ bonds using a directing group to control the site-selectivity was revealed by Kleiman and Dubeck in 1963. The ortho$\mathrm{C}-\mathrm{H}$ bond cleavage in azobenzene $\mathbf{1 3 b}$ by dicyclopentadienylnickel $\mathbf{1 4}$ led to the cyclometalated complex 15 (Scheme 4). ${ }^{[42,43]}$
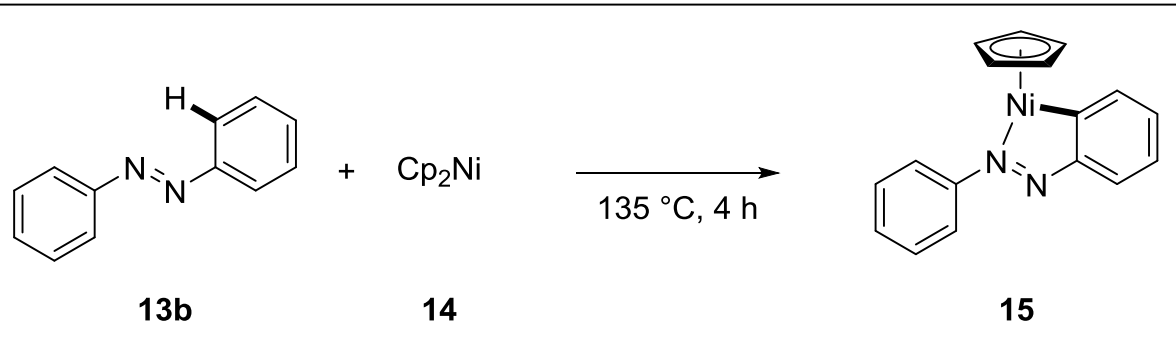

Scheme 4: Preparation of cyclonickelated complex 15 reported by Kleiman and Dubeck in 1963.

Subsequently, Cope disclosed the chelation-assisted direct palladation of azobenzene 13I at $25^{\circ} \mathrm{C}$ (Scheme 5). ${ }^{[44,45]}$ Additional examples of cyclometalation reactions by transition metal complexes were reported by Stone and Bruce. ${ }^{[46-48]}$

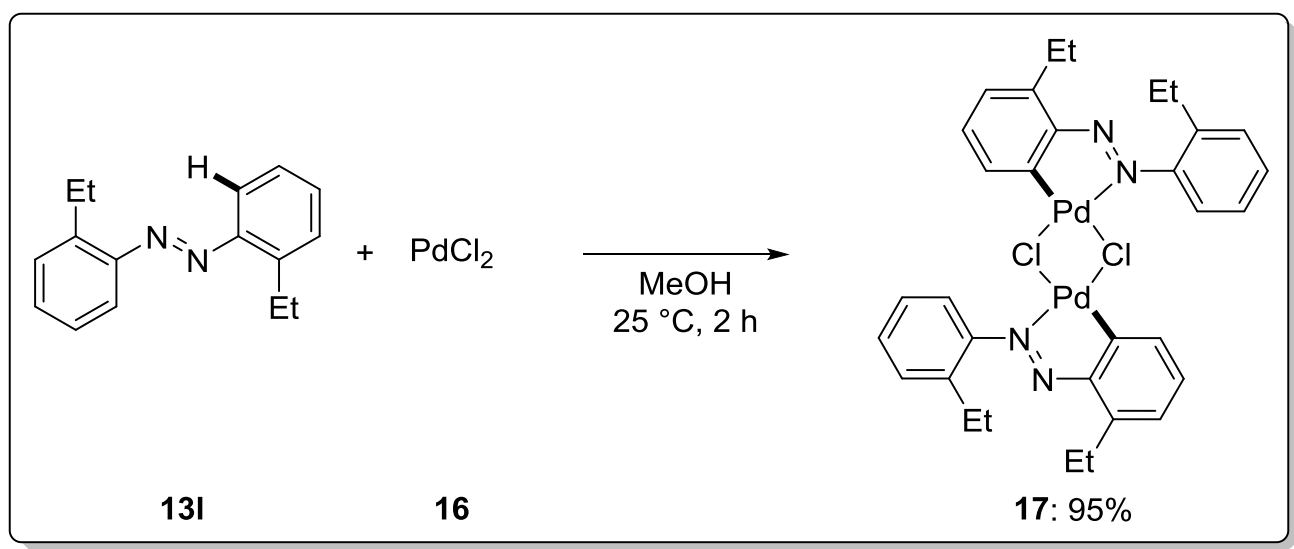

Scheme 5: Synthesis of cyclometalated complex 17 via $\mathrm{C}-\mathrm{H}$ bond activation.

In 1965, Chatt and Davidson illustrated an oxidative addition of a $\mathrm{C}\left(\mathrm{sp}^{2}\right)-\mathrm{H}$ bond from a $\pi$ coordinated naphthalene ruthenium complex 18 (Scheme 6). The ruthenium(0) complex is also active in a $\mathrm{C}\left(\mathrm{sp}^{3}\right)-\mathrm{H}$ bond functionalization of a methyl group in the dmpe [1,2-bis(dimethylphosphino)ethane] ligand. ${ }^{[43,49,50]}$ 


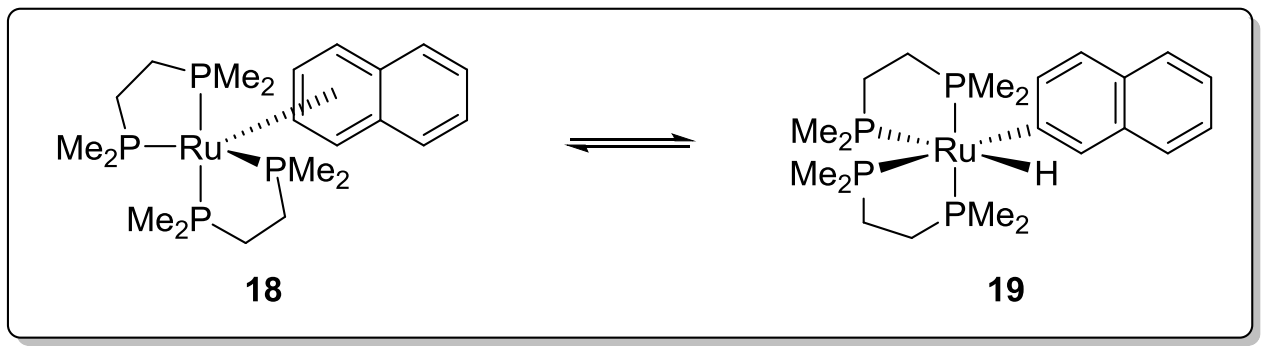

Scheme 6: Oxidative addition of a $\mathrm{C}-\mathrm{H}$ bond to yield $\mathrm{Ru}(\mathrm{H})(2$-naphthyl $)(\mathrm{dmpe})_{2}(\mathbf{1 9})$.

A noteworthy preparation of a cationic cycloruthenated complex $\mathbf{2 4}$ by direct intramolecular $\mathrm{C}-\mathrm{H}$ activation was reported by Pfeffer in 1999 (Scheme 7). ${ }^{[6,51,52]}$

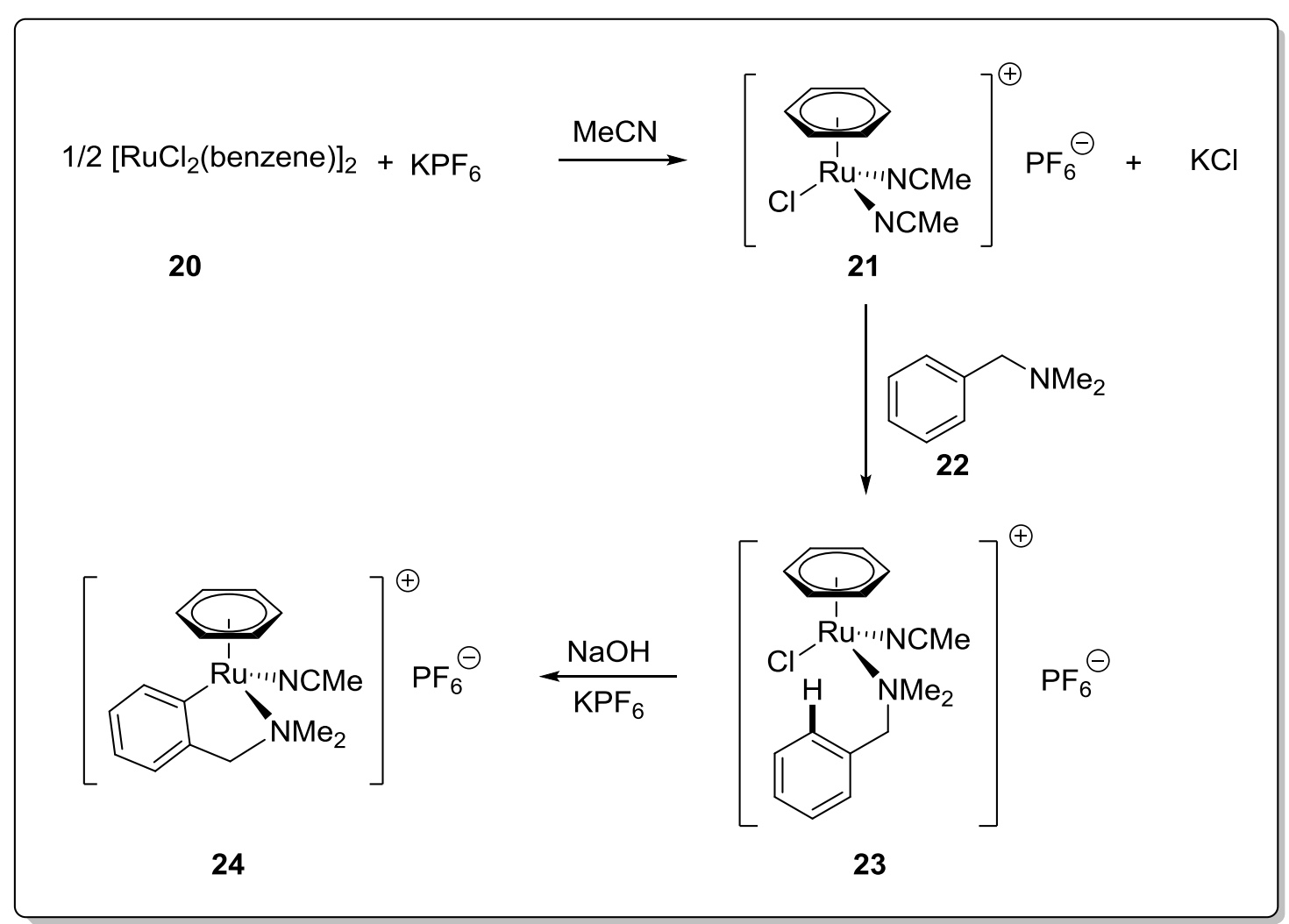

Scheme 7: Synthesis of cationic ruthena(II)cycle $\mathbf{2 4}$ by direct intramolecular C-H metalation.

Knoth and Schunn ${ }^{[53,54]}$ as well as Robinson ${ }^{[55,56]}$ independently revealed that ruthenium hydrido complex 25 in conjunction with triphenyl phosphite as ligand provided the cycloruthenated complex 26 (Scheme 8). ${ }^{[6]}$ 


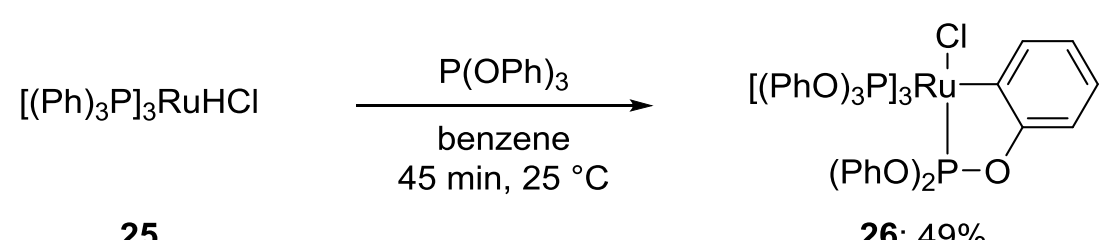

25

26: $49 \%$

Scheme 8: Synthesis of five-membered ruthena(II)cycle 26.

Notable base-assisted cyclometalations were reported for iridium, rhodium and ruthenium species. One representative example for direct ortho-C-H activation of $\mathrm{N}$-alkyl aldimine 27 by $\left[\mathrm{RuCl}_{2}(p \text {-cymene) }]_{2}(\mathbf{2 9})\right.$ is illustrated in Scheme $9 .{ }^{[7,57]}$

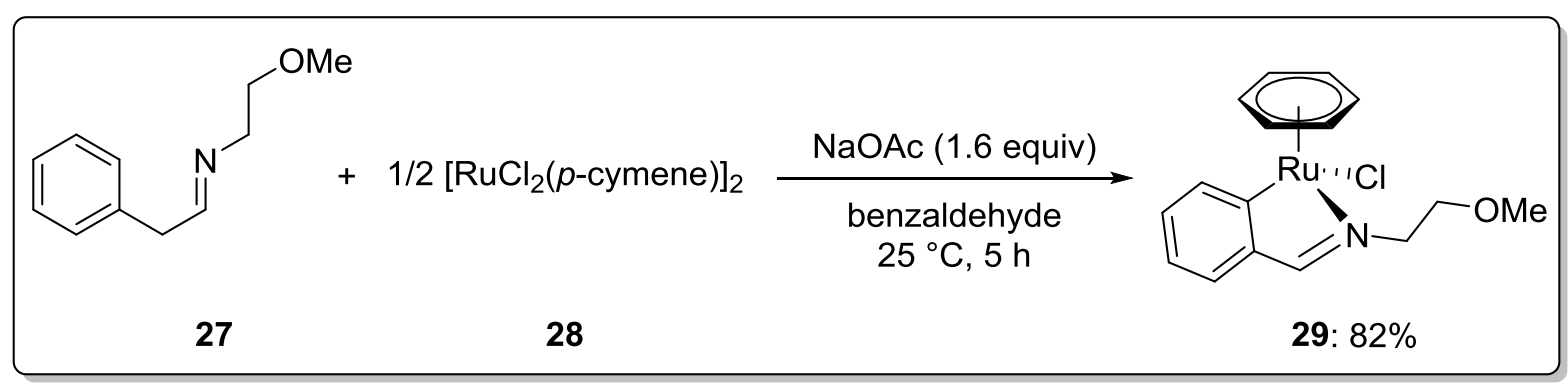

Scheme 9: Based-assisted formation of organometallic ruthenium(II) complex 29. 


\subsection{Transition metal-catalyzed $\mathrm{C}-\mathrm{H}$ functionalizations}

The stoichiometric metalation reactions previously highlighted brought substantial progress for direct functionalization approaches of otherwise inert $\mathrm{C}-\mathrm{H}$ bonds.

In 1984, Tremont presented a palladium-promoted ortho-C-H alkylation of acetanilides 30a employing alkyl iodides as the coupling partner. ${ }^{[58,59]}$ Inspired by this contribution, Daugulis published in 2005 a broadly applicable and efficient palladium-catalyzed $\mathrm{C}-\mathrm{H}$ arylation of anilides $\mathbf{3 0}$ using aryl iodides $\mathbf{3 1}$ as arylating reagents, and stoichiometric amounts of silver(I) salts. These additives were required for iodide removal from the palladium coordination sphere (Scheme 10a). ${ }^{[12,60,61]}$ Subsequently, the products 33 can be deprotected under basic hydrolysis conditions to generate valuable ortho-arylated anilines (Scheme 10b). ${ }^{[6]}$ Moreover, the use of iodonium salts as coupling partners was successfully applied to this transformation. ${ }^{[62]} \mathrm{Li}$ demonstrated another palladium-catalyzed $\mathrm{C}-\mathrm{H}$ arylation of aniline carbamate derivatives with diaryliodonium salts in good yields, including a straightforward removal of the carbamate directing group to provide the valuable 2-aminobiaryls. ${ }^{[41]}$ Unfortunately, the iodonium salts are either not commercially available or rather expensive and in this regard provide a less attractive option for a cost-effective synthesis. ${ }^{[60]}$

(a) $\mathrm{C}-\mathrm{H}$ arylation of anilides<smiles></smiles>

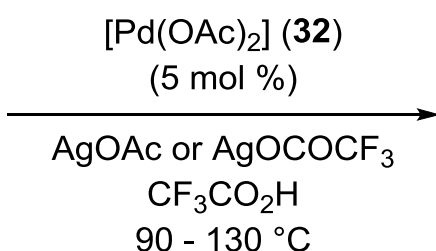

31

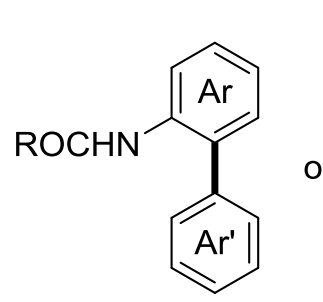

33

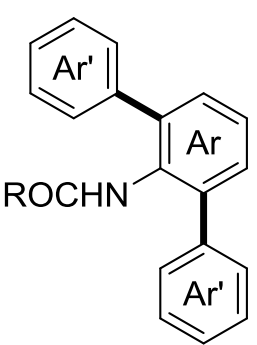

$33^{\prime}$

(b) Deprotection<smiles>COc1cccc(-c2cc(C)cc(C)c2)c1NC(C)=O</smiles>

33ub<smiles>COc1cccc(-c2cc(C)cc(C)c2)c1N</smiles>

34ub: $90 \%$

Scheme 10: Access to ortho-arylated anilines by palladium catalysis. 
A proposed catalytic cycle is initiated by cyclopalladation of the anilide $\mathbf{3 0}$ followed by oxidative addition of the organic electrophile $\mathbf{3 1}$ to provide the highly active palladium(IV) species 36. Afterwards, reductive elimination liberates product $\mathbf{3 3}$ and finally anion exchange regenerates the catalytically active palladium(II) complex $\mathbf{3 4}$ to complete the cycle (Scheme 11). ${ }^{[6,12]}$

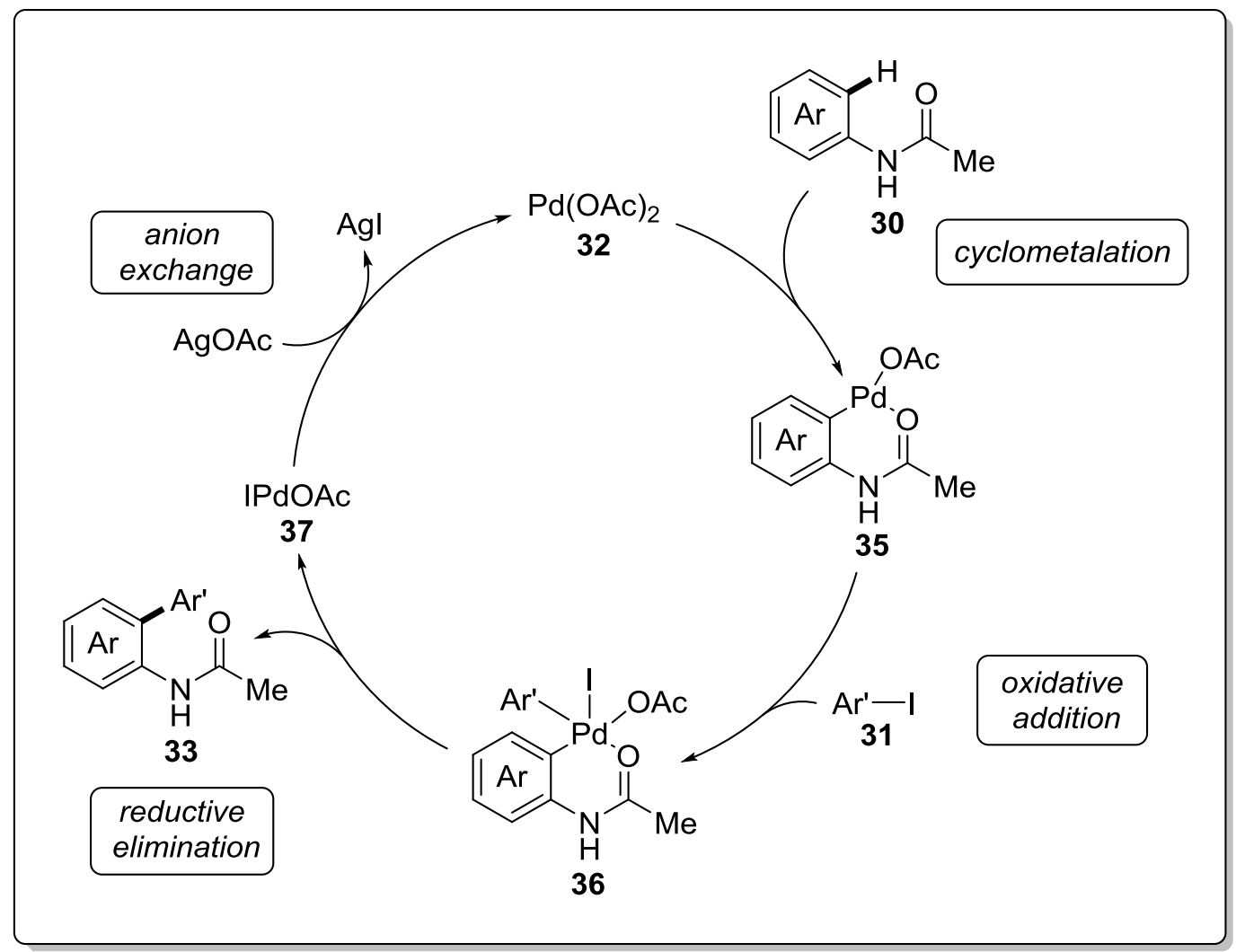

Scheme 11: Proposed catalytic cycle for palladium-catalyzed C-H arylation.

Several accounts have appeared on palladium-catalyzed ortho-C-H arylations of anilide derivatives. ${ }^{[6,12,27,28,62-64]}$ Shi described methods to construct $\mathrm{C}-\mathrm{C}$ bonds via $\mathrm{C}-\mathrm{H}$ activation. First, a Hiyama-type coupling between acetanilides $\mathbf{3 0}$ and trialkoxyarylsilanes. ${ }^{[27]}$ Second, a Suzuki-Miyaura Type coupling of $\mathrm{N}$-alkyl acetanilides 30 with aromatic boronic acids, another class of transmetalating reagents that can be employed for such direct arylation reactions. ${ }^{[28]}$ Nevertheless, in either instance silver(I) and copper(II) salts are used as terminal oxidants. Third, an oxidative cross-dehydrogenative arylation (CDA) was devised without the requirement for prefunctionalized acetanilides or the corresponding arenes, which are commercially readily available. ${ }^{[29]}$ Additionally, Buchwald developed an oxidative arylation of anilides by twofold $\mathrm{C}-\mathrm{H}$ activation to manufacture biaryls in the presence of oxygen as the terminal oxidant. ${ }^{[30]}$ Further recent reports of palladium-catalyzed CDAs among anilides and 
arenes were reported by Dong, ${ }^{[31]}$ Glorius ${ }^{[32]}$ and You. ${ }^{[33]}$ However, regioisomeric mixtures were often obtained, with the arenes as arylating reagents being used in overstoichiometric amounts.

Lipshutz described sophisticated $\mathrm{C}-\mathrm{H}$ arylations of urea derivatives with aryl iodides or arylboronic acids as coupling partners at $25{ }^{\circ} \mathrm{C}$, affording an alternative route to synthetically valuable ortho-arylated anilines, after deprotection of the dimethylurea moiety under basic reaction conditions. ${ }^{[63,64]}$

Recent accounts for transition metal-catalyzed ortho-arylations of anilides were published by Wang ${ }^{[65]}$ and Cheng. ${ }^{[66]}$

To date, palladium has been the most investigated transition metal in coupling chemistry, but from an economical point of view interest in utilizing the less expensive transition metal ruthenium are gaining importance as a feasible alternative. ${ }^{[15,44 a]}$ In this regard, the recently published ruthenium-catalyzed $\mathrm{C}-\mathrm{H}$ arylation by Lakshman demonstrated a superior performance against the palladium counterpart for 6-phenylpurine derivatives, which are of great importance in medicinal chemistry. ${ }^{[67,68]}$

In 1986, Lewis presented the first ruthenium(0)-catalyzed $\mathrm{C}-\mathrm{C}$ bond formation by chelation assistance. ${ }^{[69]}$ Kakiuchi, Chatani and Murai rendered crucial contributions for ruthenium(0)catalyzed transformations concerning hydroalkylation and hydroalkenylation, ${ }^{[70-72]}$ silylation, ${ }^{[73,74]}$ and arylation. ${ }^{[6,75,76]}$ An interesting work is the efficient ruthenium(0)catalyzed $\mathrm{C}-\mathrm{H}$ arylation of aryl ketones $\mathbf{3 8}$ using boronates $\mathbf{3 9}$ as arylating reagents with an ample scope and relevant mechanistic insights (Scheme 12).

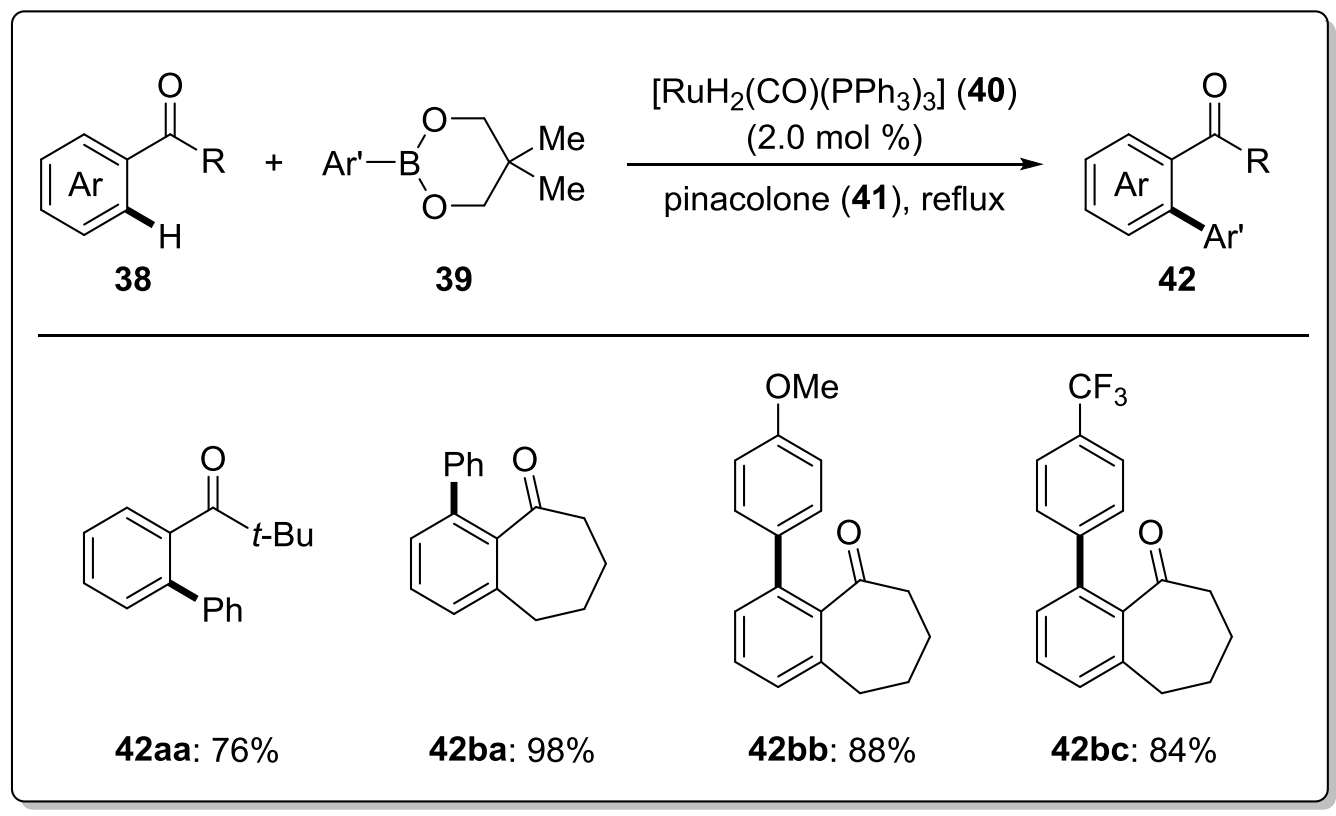

Scheme 12: Ruthenium(0)-catalyzed C-H arylation of aryl ketones $\mathbf{3 8}$ with boronates $\mathbf{3 9}$ in pinacolone. 
The aliphatic ketone pinacolone $\mathbf{4 1}$ has an essential function as acceptor for the hydrogen of the ortho- $\mathrm{C}-\mathrm{H}$ bond of aryl ketone 38 and the $\mathrm{B}(\mathrm{OR})_{2}$ moiety of the aryl boronate 39 . The use of pinacolone 41 suppressed the reduction of the aryl ketone 38 to achieve high yields. The kinetic isotope effects for the inter- and intramolecular competition experiments indicated that the oxygen of the ketone carbonyl group coordinates to the ruthenium-complex prior to $\mathrm{C}-\mathrm{H}$ bond cleavage. A proposed catalytic cycle is illustrated in Scheme 13. Initially the carbonyl oxygen of the ketone $\mathbf{3 8}$ coordinates to the ruthenium species $\mathbf{4 0}$. Thereafter, oxidative addition to provide the five-membered ruthenacycle $\mathbf{4 4}$ followed by insertion of pinacolone 41 into the $[\mathrm{Ru}]-\mathrm{H}$ bond to deliver the alkoxy ruthenium complex 45 . Transmetalation and subsequent reductive elimination leads to the desired product $\mathbf{4 2}$ and regenerates the active catalyst 40. ${ }^{[6,75,76]}$

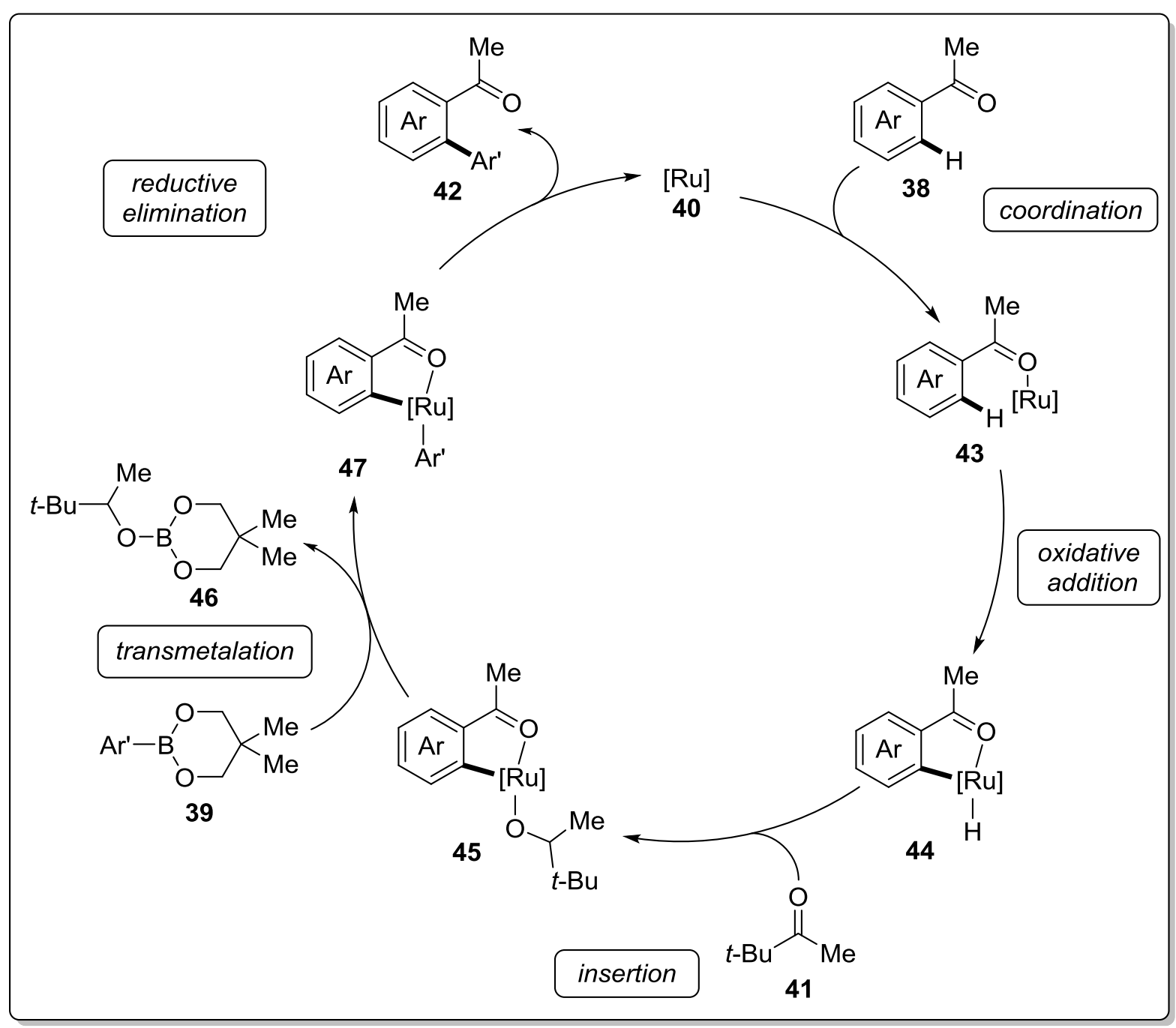

Scheme 13: Proposed catalytic cycle for ruthenium(0)-catalyzed C-H arylation.

Recent reports for ruthenium-catalyzed $\mathrm{C}-\mathrm{H}$ arylations using boron-based arylating reagents were published by Szostak, ${ }^{[77]}$ Ramana, ${ }^{[78]}$ Jeganmohan, ${ }^{[25]}$ and Wan. ${ }^{[26]}$ 
In 2008, Miura published the first transition metal-catalyzed direct arylation of azobenzene with arylboronic acids as coupling partners and a rhodium complex as catalyst, achieving unsatisfactory yields. ${ }^{[79]}$ Thereafter, Zeng reported a palladium-catalyzed ortho-arylation of azoarenes with aryl acylperoxides. ${ }^{[80]}$ Further progress was represented by rhodium- and palladium-catalyzed direct functionalizations of azoarenes. ${ }^{[81-98]}$ Despite these advances, at that time there existed no report for the transition metal-catalyzed $\mathrm{C}-\mathrm{H}$ arylation, using aryl halides as coupling partners for expedient access to ortho-arylated anilines, after a simple reduction of the azo group. In 2001, Oi and Inoue presented an overall isohypsic rutheniumcatalyzed direct arylation with readily available and ecologically benign aryl bromides $\mathbf{5 2}$ as coupling partner by chelation assistance of the pyridyl-substituted arenes $48{ }^{[99]}$ Thereafter, this catalytic system proved to be applicable to aryl imines 49, oxazolines $\mathbf{5 0}$ and imidazolines 51, which can be subsequently converted into other functionalities for further chemical transformations (Scheme 14). ${ }^{[6,100,101]}$

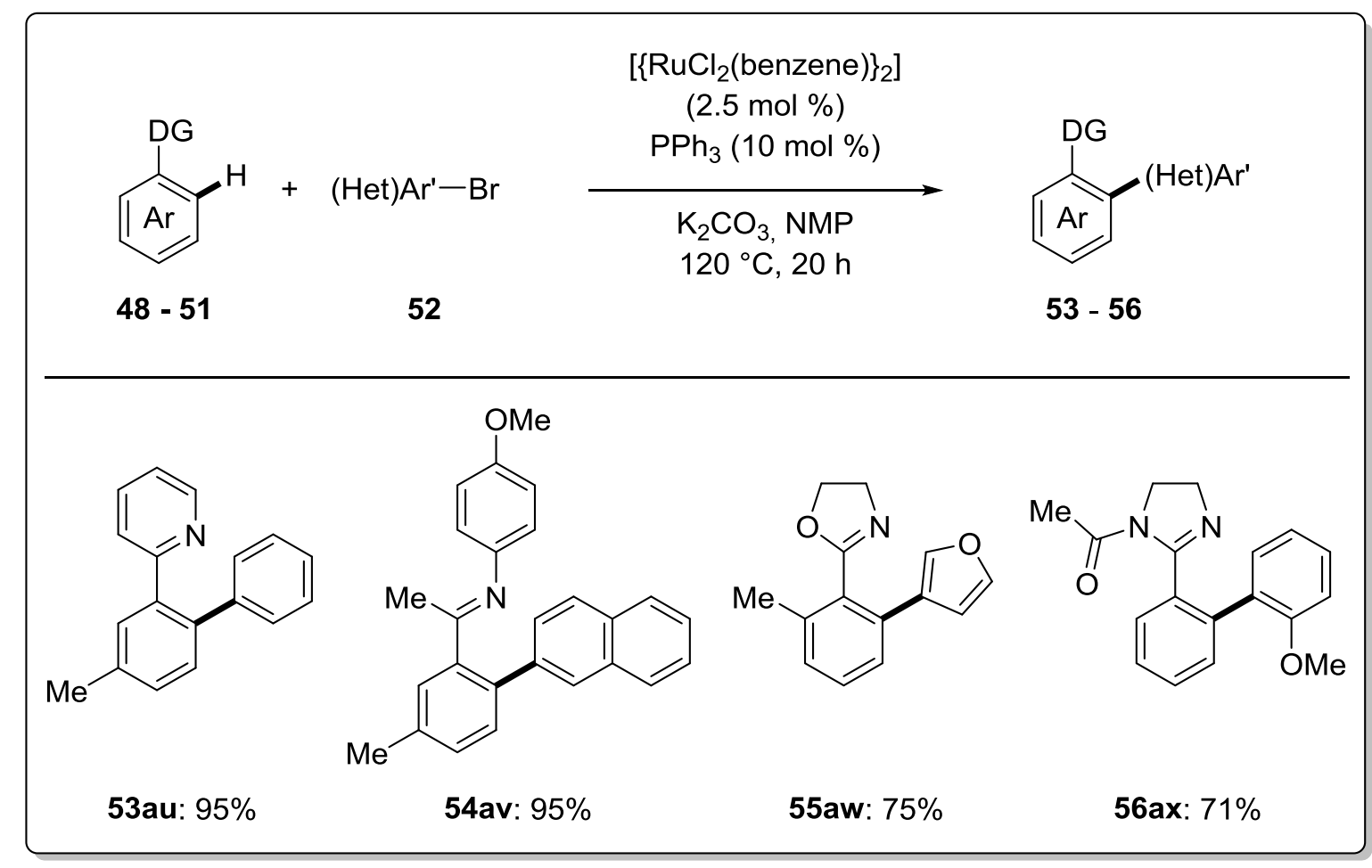

Scheme 14: Ruthenium(II)-catalyzed C-H arylation with (hetero)aryl bromides 52.

From the economical point of view the use of the inexpensive $\left[\mathrm{RuCl}_{3}\left(\mathrm{H}_{2} \mathrm{O}\right)_{n}\right]$ catalyst is desirable. In this context, Ackermann presented a $\left[\mathrm{RuCl}_{3}\left(\mathrm{H}_{2} \mathrm{O}\right)_{n}\right]$-catalyzed $\mathrm{C}-\mathrm{H}$ arylation of pyridine, oxazoline and pyrazole as pronucleophiles using aryl bromides, even the more challenging sterically hindered ortho-substituted, in the absence of an additional co-catalyst. ${ }^{[102]}$ The challenging but inexpensive and readily accessible chlorides as arylating reagents arouse interest in academia and beyond. Ackermann presented a highly efficient 
ruthenium(II) catalytic system based on the secondary phosphine oxide (SPO) (1-Ad) ${ }_{2} \mathrm{P}(\mathrm{O}) \mathrm{H}$ as pre-ligand for $\mathrm{C}-\mathrm{H}$ functionalization of pyridines and imines with aryl chlorides. ${ }^{[103]}$ The exchange of the pre-ligand $(1-\mathrm{Ad})_{2} \mathrm{P}(\mathrm{O}) \mathrm{H}$ through heteroatom substituted secondary phosphine oxide (HASPO) 57 enhanced the catalyst performance, realizing a direct arylation of pyridine 53, oxazoline 55 and pyrazole 58 derivatives with aryl chlorides 59 and even tosylates $\mathbf{6 0} .{ }^{[104]}$ Of note is the general trend for the mono- or diarylation, which is controlled by the selection of the appropriate electrophile. Thus, aryl chloride 59b provided mainly the diarylated product 61 ba', while the analogous aryl tosylate $60 \mathrm{a}$ furnished to monoarylated product $61 \mathrm{ba}$ (Scheme 15). ${ }^{[6,104]}$

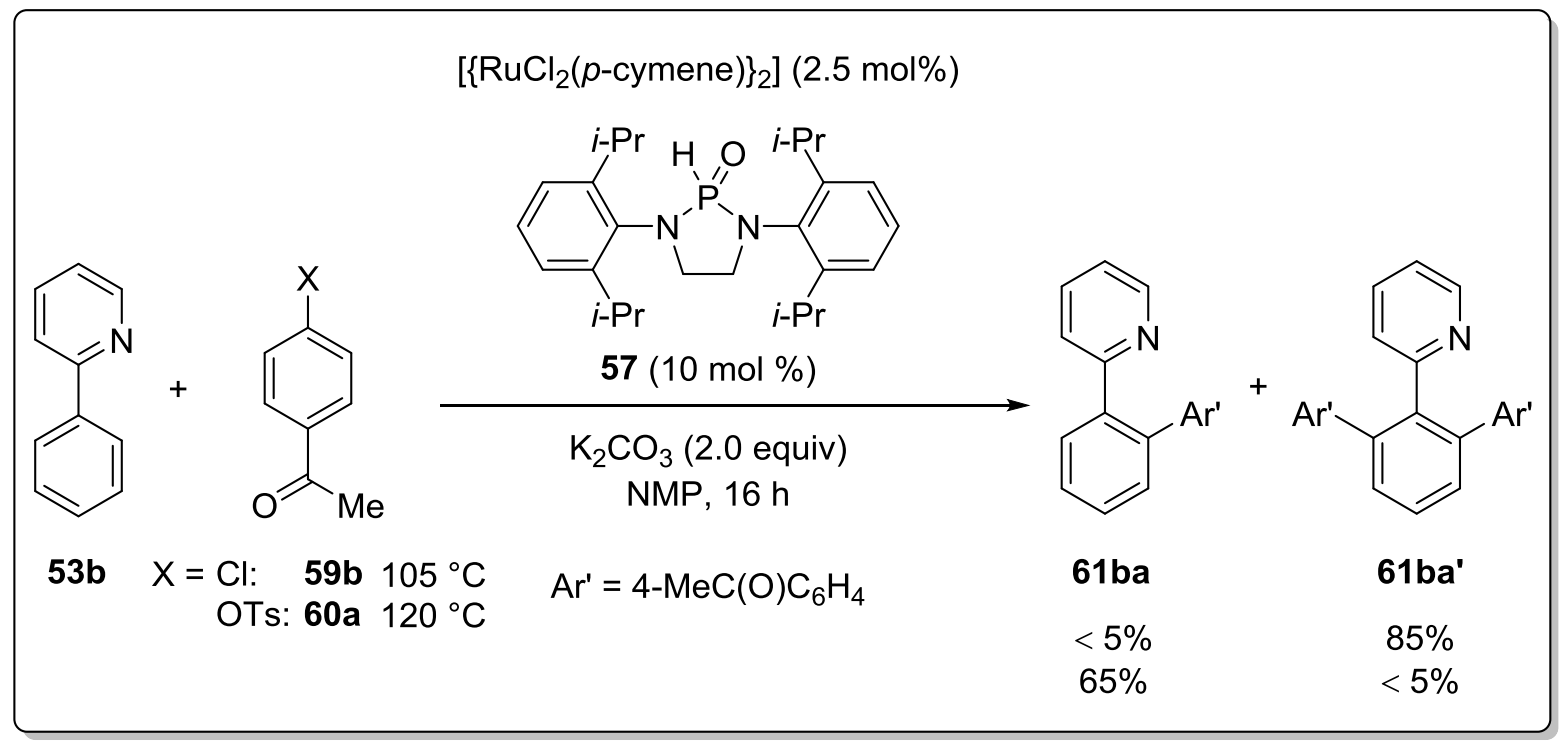

Scheme 15: Selective ruthenium(II)-catalyzed C-H arylation controlled by the choice of the electrophile.

The use of aryl pseudo-halides as surrogates for aryl halides is an attractive option, since they can be manufactured from cost-effective and easily accessible phenols. ${ }^{[105]}$ Referring to this, ruthenium(II)-catalyzed $\mathrm{C}-\mathrm{H}$ arylation of oxazolinyl-, pyrazolyl- and pyridyl- substituted arenes with phenols via $\mathrm{C}-\mathrm{H}$ and $\mathrm{C}-\mathrm{OH}$ bond functionalizations represented a further advance, regarding the step economy of such processes. ${ }^{[106,107]}$

The impact of the regio- and chemoselectivity by transition metal-catalyzed $\mathrm{C}-\mathrm{H}$ arylations was also demonstrated on 1,2,3-triazoles 62. The palladium- or copper-catalyzed direct functionalizations occurred selectively at the triazol moiety, whereas the ruthenium(II) catalysis was selectively achieved at the arene moiety (Scheme 16). ${ }^{[108-110]}$ 


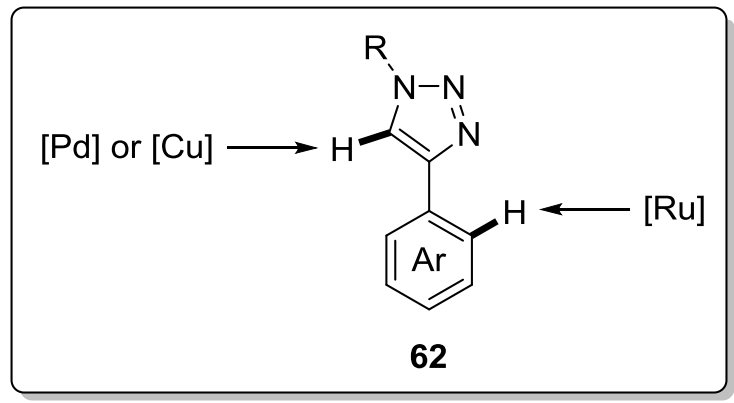

Scheme 16: Complementary regioselectivities in transition metal-catalyzed $\mathrm{C}-\mathrm{H}$ functionalizations of 1,2,3-triazoles $\mathbf{6 2}$.

The chemoselectivity for the carboxylate-assisted ruthenium(II)-catalyzed $\mathrm{C}-\mathrm{H}$ arylation of 1,2,3-triazol-4-yl-substituted arenes $\mathbf{6 2}$ with aryl halides $\mathbf{6 3}$ was discovered to depend on the substitution pattern of both substrates. The catalytic system exhibited a wide substrate scope for the direct arylation (Scheme 17a), but the use of electron-rich ortho-alkylated arenes $\mathbf{6 2}$ in conjunction with ortho-substituted aryl halides 63 preferentially led to the oxidative dehydrogenative homo-coupling product 65 (Scheme 17b). ${ }^{[108]}$

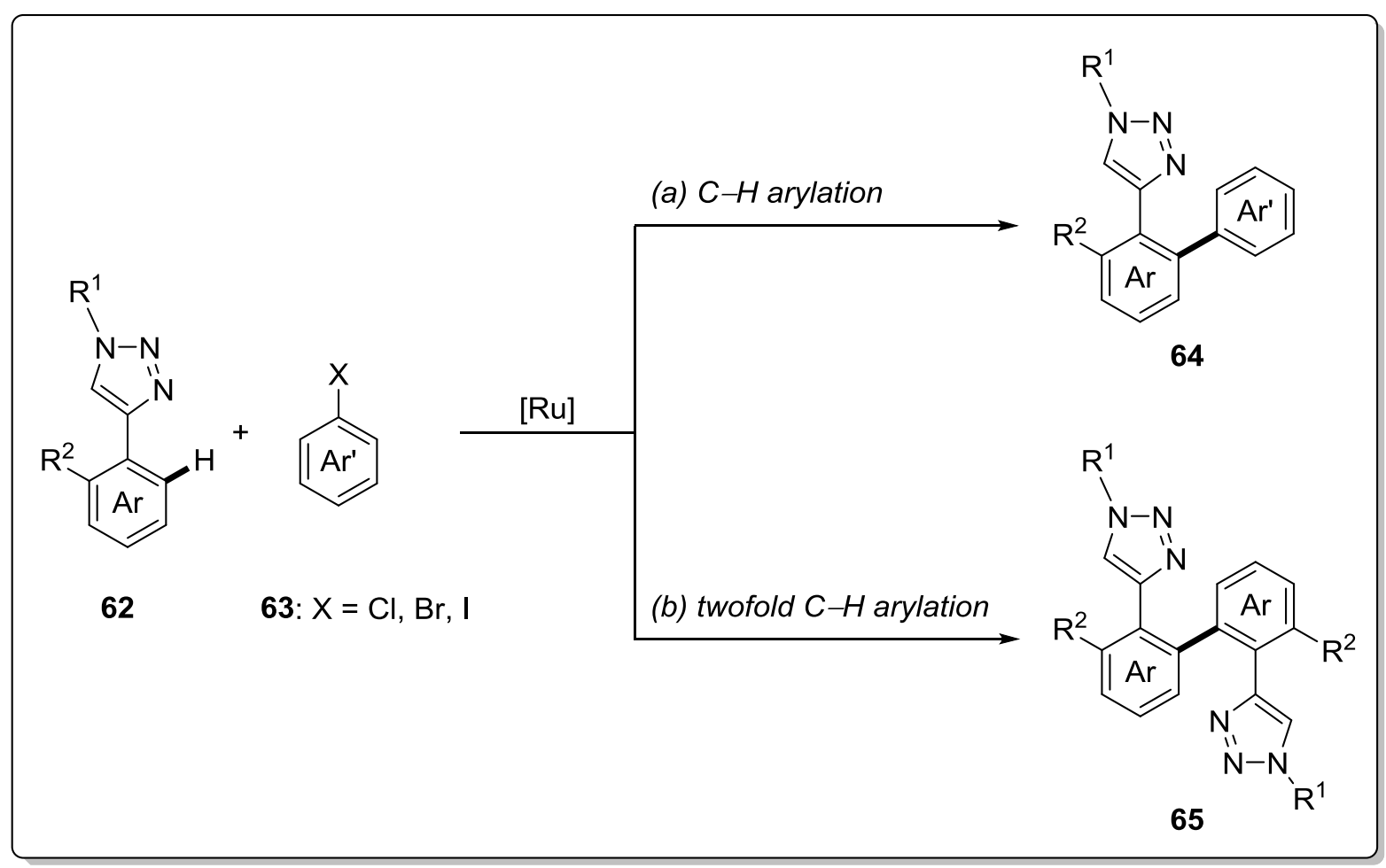

Scheme 17: Chemoselectivity of ruthenium(II)-catalyzed C-H functionalization: (a) direct arylation versus (b) oxidative dehydrogenative homo-coupling. 
Fundamental mechanistic studies on palladium-catalyzed $\mathrm{C}-\mathrm{H}$ bond activation ${ }^{[11]}$ and subsequent functionalization led to the assumption that the $\mathrm{C}-\mathrm{H}$ bond cleavage is assisted by basic pre-ligands such as carboxylates or carbonates in a concerted metalation-deprotonation (CMD) process. ${ }^{[6,7,112-116]}$ A concerted metalation-deprotonation (CMD) ${ }^{[110]}$ mechanism in the ruthenium-catalyzed $\mathrm{C}-\mathrm{H}$ arylations using the beneficial effect of pre-ligands to facilitate the elementary step of the $\mathrm{C}-\mathrm{H}$ ruthenation, proceeding via five- or six-membered transition state 66 or 67 , respectively (Scheme 18). ${ }^{[7]}$

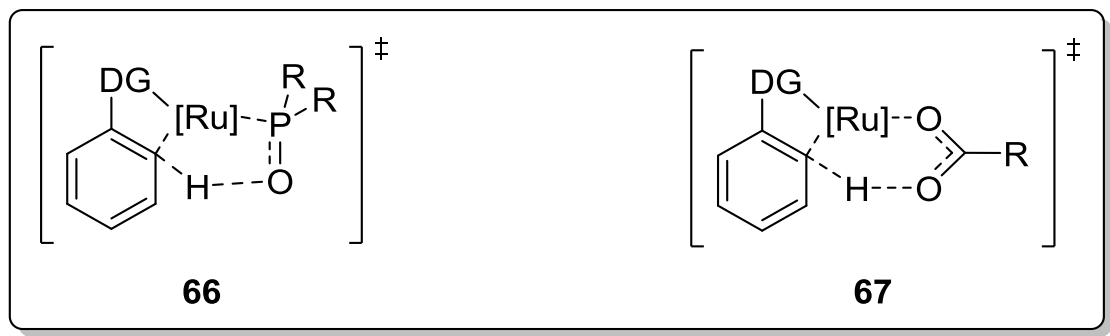

Scheme 18: Proposed transition states 66 and 67 for base-assisted intramolecular cycloruthenation.

The efficient and selective carboxylate-assisted ruthenium-catalyzed $\mathrm{C}-\mathrm{H}$ functionalizations proved to be robust and broadly applicable. ${ }^{[7,15,117]}$ The catalytic system represented an ecologically benign and economically attractive tool for the synthesis of important bioactive compounds. Concerning this matter, the practical importance of the ruthenium-catalyzed $\mathrm{C}-\mathrm{H}$ arylation strategy was demonstrated by the synthesis of 5-biaryl-1H-tetrazoles $69 \mathbf{k u}$, key structural motifs in a variety of nonpeptidic angiotensin II receptor blockers (ARBs) (Scheme 19). ${ }^{[15,17,118-122]}$ Previously, the biaryl tetrazoles were synthesized through palladiumcatalyzed cross-coupling reactions with the fundamental drawback on the synthesis and use of prefuntionalized starting materials, which is cost-ineffective and harmful to the environment. $^{[123-125]}$ 


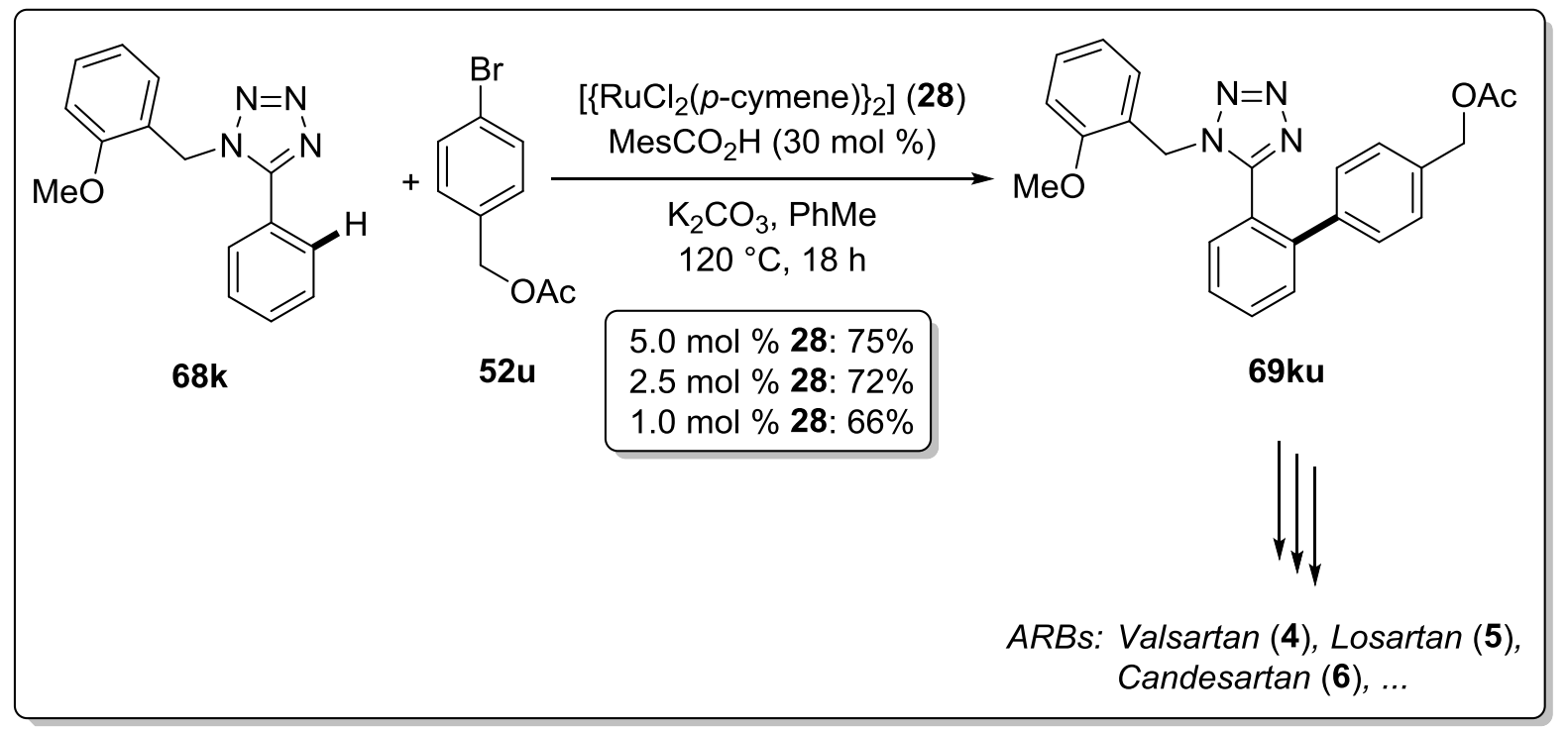

Scheme 19: Application of ruthenium(II)-catalyzed C-H arylation for the synthesis of 69ku, key intermediate of ARBs.

Recently, Ackermann reported a step-economical direct synthesis of protected Valsartan ${ }^{[126-130]}$ 69at via $\mathrm{C}-\mathrm{H}$ activation and set the stage for an atom-economical approach to blockbuster antihypertension drugs, which should prove instrumental for industrial applications (Scheme 20). ${ }^{[131]}$ Unfortunately, the ruthenium(II)-catalyzed $\mathrm{C}-\mathrm{H}$ arylations of 5-aryl-1H-tetrazoles were not compatible to the readily available and economically more attractive aryl chlorides at this stage.

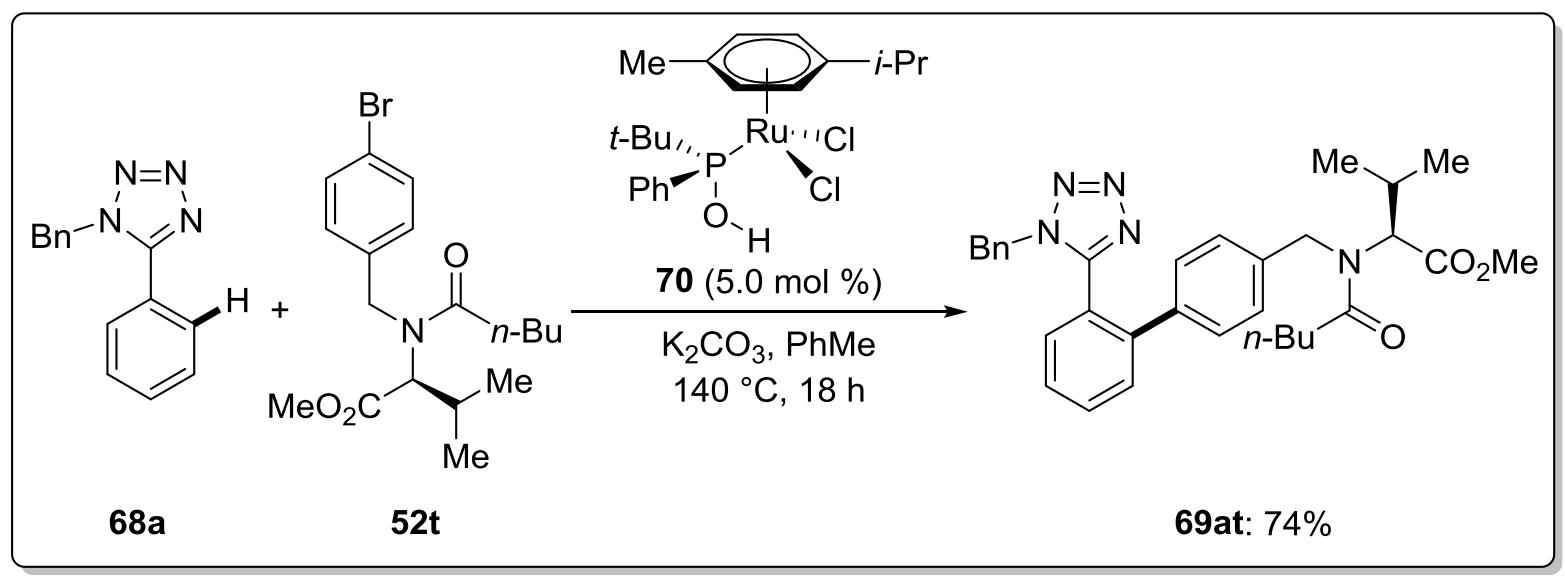

Scheme 20: Step-economical access to protected Valsartan 69at by ruthenium-catalyzed C-H arylation.

The development of innovative environmentally benign and economically attractive catalytic processes for $\mathrm{C}-\mathrm{H}$ arylation and its application to practical and scalable syntheses of valuable bi(hetero)aryls as key molecular frameworks in various bioactive compounds is an ongoing key interest in academia and industry. 


\section{Objectives}

The goal of this work was to devise environmentally friendly and cost-effective novel concepts for the efficient synthesis of biaryl units as core structure in biologically active compounds, which are of great importance to the agrochemical and pharmaceutical industries. ${ }^{[6,9,15,17]}$ To address this challenge, the direct $\mathrm{C}-\mathrm{H}$ bond arylation processes are in high demand. ${ }^{[5-13,15-17]}$ Particularly, robust and versatile ruthenium(II) complexes have emerged as powerful catalysts for selective $\mathrm{C}-\mathrm{H}$ transformations by chelation assistance. $^{[10,15,17,117,132,133]}$ Moreover, kinetic investigations should be carried out for the clarification of the reaction mechanism.

The mono-selective $\mathrm{C}-\mathrm{H}$ arylation of anilides received considerable attention, as 2-aminobiaryls are key structural frameworks in drug and crop protection agents. ${ }^{[6,12,27,28,60-64]}$ Recently, palladium-catalyzed ortho-C-H functionalizations of anilides had been developed by several research groups, contrary to ruthenium-catalyzed systems, which are rarely explored. ${ }^{[6,29-31,33,132,134-136]}$ In this context, it should take advantage of the less expensive ruthenium for the demanding direct arylation of anilides $\mathbf{3 0}$ in a broadly applicable and highly selective fashion (Scheme 21).

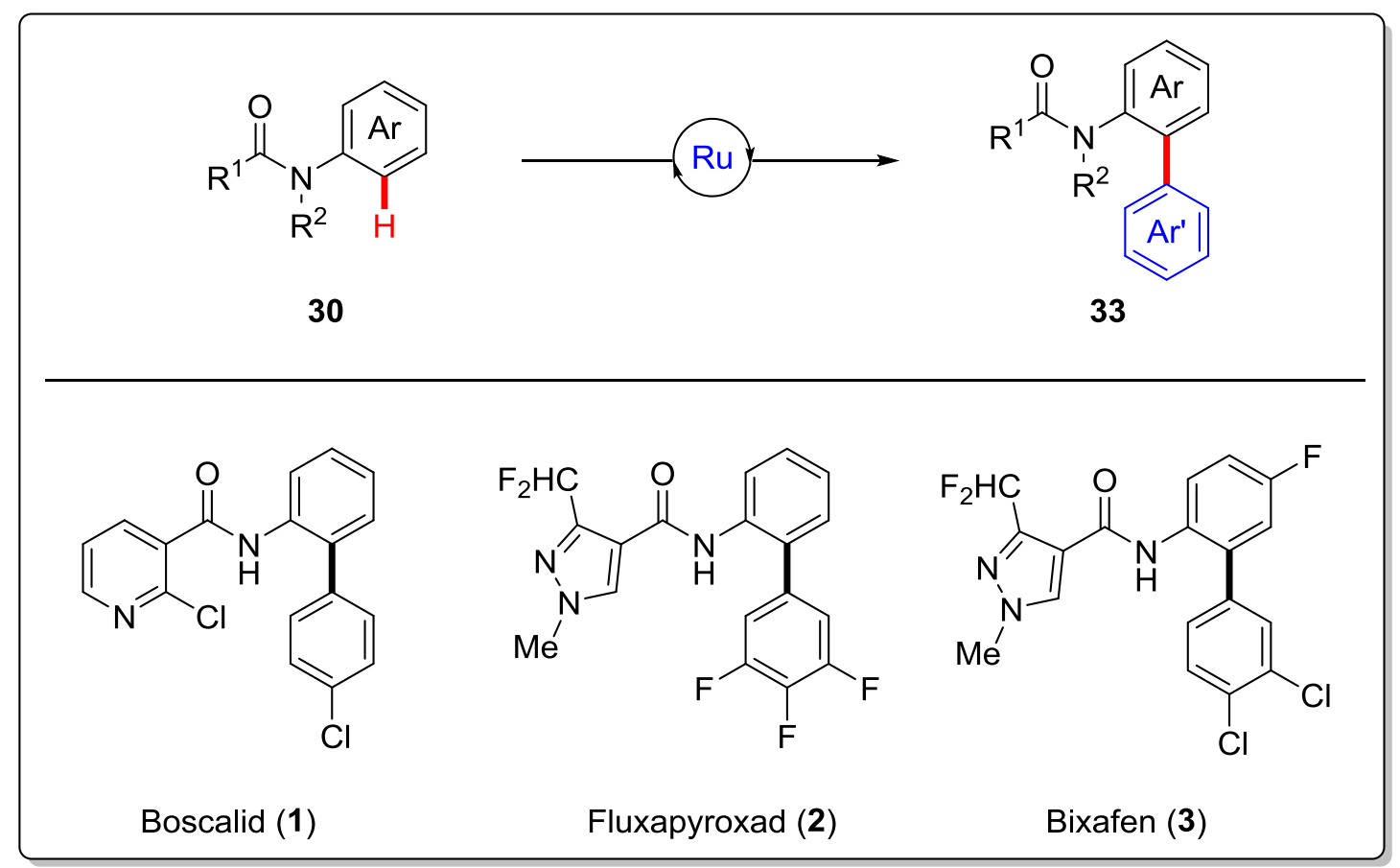

Scheme 21: Ruthenium(II)-catalyzed C-H arylation for syntheses of key intermediates $\mathbf{3 3}$ of relevance to fungicides. 
After a successful solution for the previously described issue via an oxidative ruthenium(II)catalyzed $\mathrm{C}-\mathrm{H}$ arylation of anilides 30 with boron-based arylating reagents, additional investigations were required for an overall redox-neutral variant to avoid stoichiometric metal salts as terminal oxidants using aryl halides $\mathbf{6 3}$ as coupling partners ${ }^{[7]}$ along with direct access to synthetically useful ortho-arylated anilines (Scheme 22).

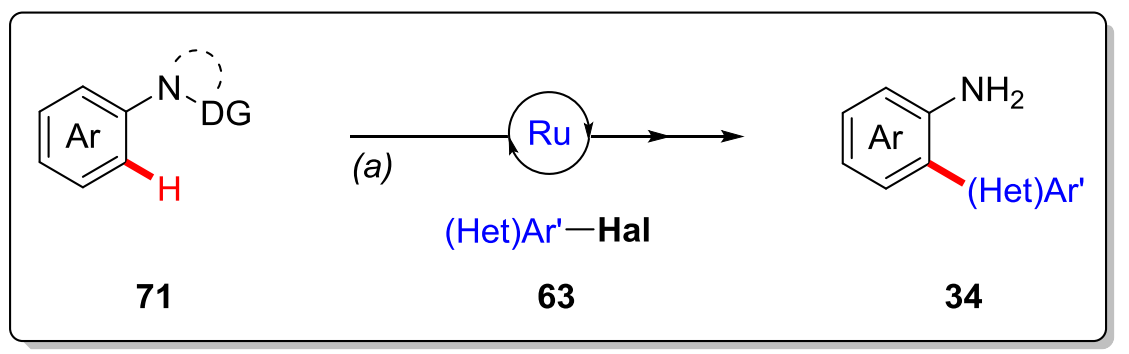

Scheme 22: A general concept for expedient access to ortho-arylated anilines $\mathbf{3 4}$ via $\mathrm{C}-\mathrm{H}$ activation strategy.

The outstanding performance of the ruthenium(II) complexes by chelation assistance was among others highlighted by prior findings and should be exploited in the drug development. ${ }^{[15,17,117]}$ In this respect, Ackermann recently reported the most step-economical access to the nonpeptidic angiotensin II receptor blocker (ARB) Valsartan (4). ${ }^{[131]}$ Further improvement should be done by employing challenging aryl chlorides concerning the cost efficiency, which would be a promising achievement for future industrial applications (Scheme 23).

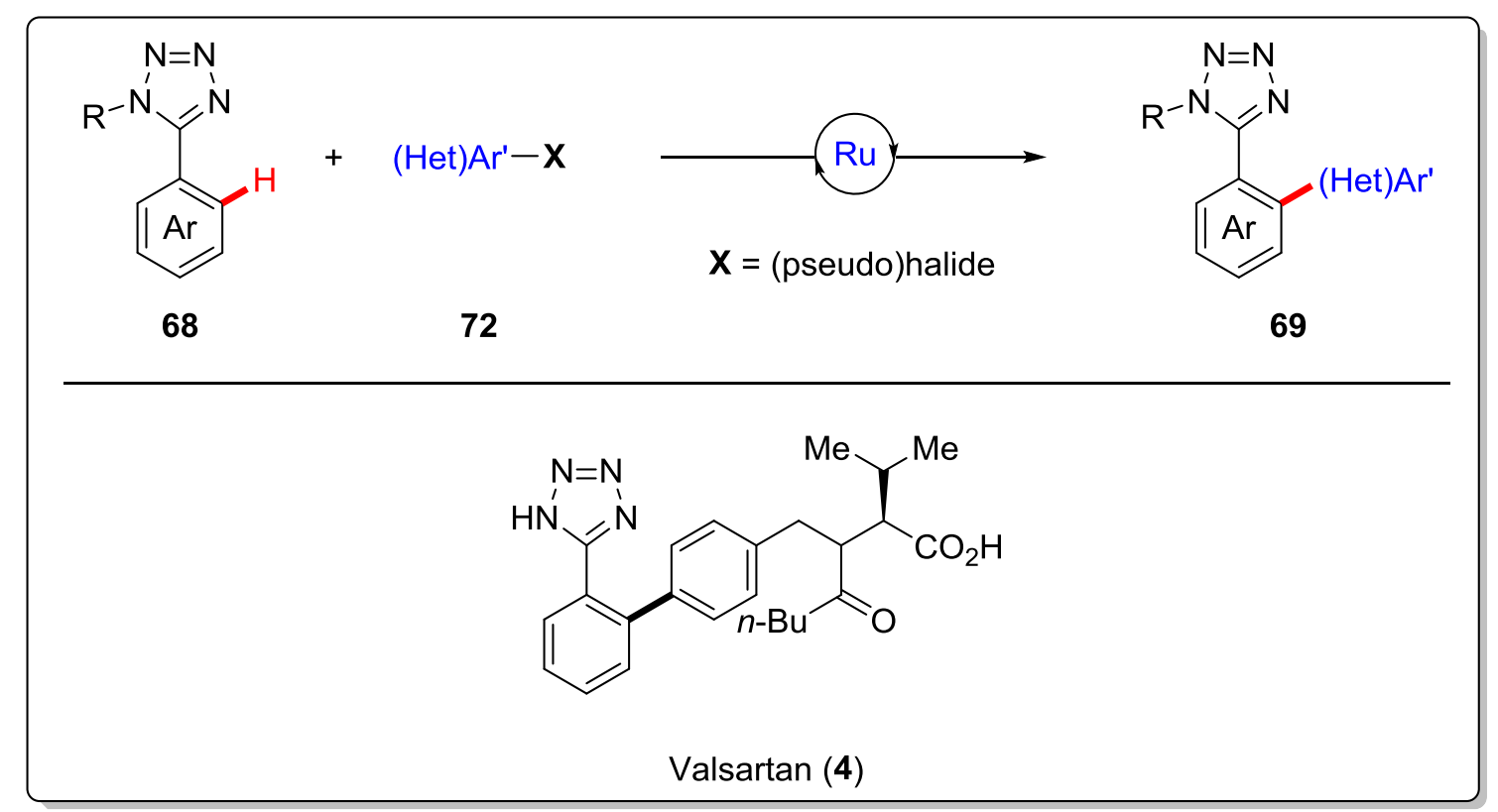

Scheme 23: Step-economical approach for blockbuster antihypertension drug Valsartan (4) by C-H arylation. 


\section{Results and Discussion}

\subsection{Ruthenium(II)-catalyzed $\mathrm{C}-\mathrm{H}$ arylation of anilides with boronic acids, borinic acids and potassium trifluoroborates}

\subsubsection{Optimization of $\mathrm{C}-\mathrm{H}$ arylation of acetanilide with phenylboronic acids}

During the comprehensive and systematic optimization studies, different additives, ruthenium catalysts, solvents and oxidants were tested to deliver the desired product 33aa (Tables 1-3). Initial reactions revealed that in the absence of the catalyst no product was formed (Table 1, entry 1). The combination of $\left[\left\{\mathrm{RuCl}_{2}(p \text {-cymene })\right\}_{2}\right]$ and $\mathrm{Cu}(\mathrm{OTf})_{2}$ provided the best result, whereas $\mathrm{AgSbF}_{6}$ accomplished an effective cationic ruthenium(II) species. Utilization of the less expensive $\mathrm{CuSO}_{4}$ and $\mathrm{CuO}$ additives was successful as well (entries 5-6). Other ruthenium catalysts or additives gave less satisfactory results. Afterwards, a catalyst loading of $5.0 \mathrm{~mol} \%$ was shown to be essential to obtain good yields of the ortho-arylated product 33aa (entry 15). Reducing the catalyst loading resulted in unsatisfactory yields of biaryl product 33aa (entry 16).

Table 1: Effect of additives and ruthenium catalysts. ${ }^{[a]}$

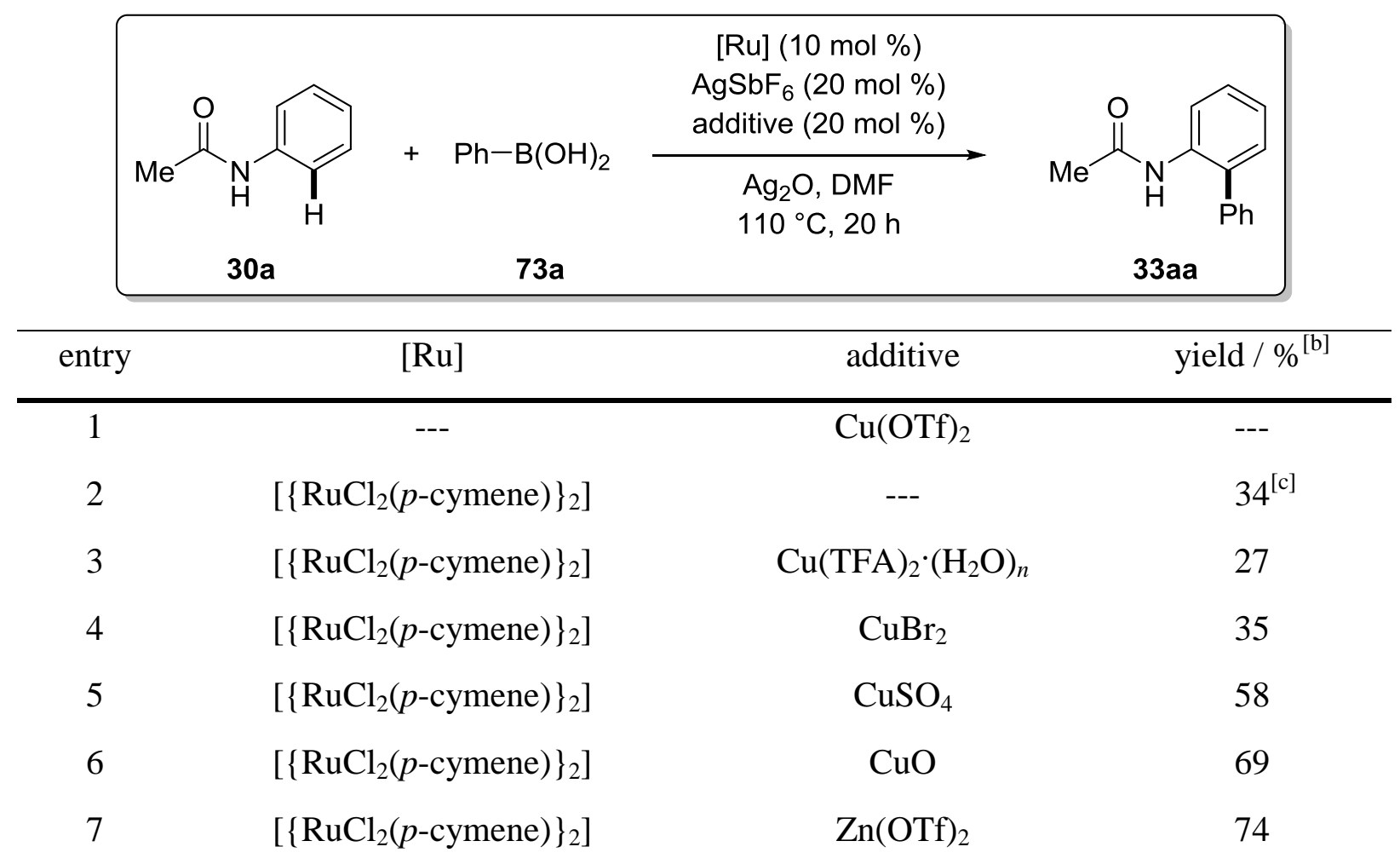




\begin{tabular}{cccc}
8 & {$\left[\left\{\mathrm{RuCl}_{2}(p \text {-cymene })\right\}_{2}\right]$} & $\mathrm{NaOTf}$ & 65 \\
9 & {$\left[\left\{\mathrm{RuCl}_{2}(p \text {-cymene })\right\}_{2}\right]$} & $\mathrm{AgOTf}$ & 59 \\
10 & {$\left[\left\{\mathrm{RuCl}_{2}(p \text {-cymene })\right\}_{2}\right]$} & $\mathrm{AgOTf}$ & $49^{[\mathrm{d}]}$ \\
11 & {$\left[\left\{\mathrm{RuCl}_{2}(p \text {-cymene })\right\}_{2}\right]$} & $\mathrm{TfOH}$ & 50 \\
12 & {$\left[\mathrm{RuCl}_{3}\left(\mathrm{H}_{2} \mathrm{O}\right)_{n}\right]$} & $\mathrm{Cu}(\mathrm{OTf})_{2}$ & --- \\
13 & {$\left[\mathrm{Cp}^{*} \mathrm{Ru}_{\left.\left(\mathrm{PPh}_{3}\right)_{2} \mathrm{Cl}\right]}\right.$} & $\mathrm{Cu}(\mathrm{OTf})_{2}$ & 21 \\
14 & {$\left[\left\{\mathrm{RuCl}_{2}(\text { benzene })\right\}_{2}\right]$} & $\mathrm{Cu}(\mathrm{OTf})_{2}$ & 22 \\
15 & {$\left[\left\{\mathrm{RuCl}_{2}(p \text {-cymene })\right\}_{2}\right]$} & $\mathrm{Cu}(\mathrm{OTf})_{2}$ & $77^{[\mathrm{c}]}$ \\
16 & {$\left[\left\{\mathrm{RuCl}_{2}(p \text {-cymene })\right\}_{2}\right]$} & $\mathrm{Cu}(\mathrm{OTf})_{2}$ & $48^{[\mathrm{b}, \mathrm{e}]}$ \\
\hline
\end{tabular}

${ }^{[a]}$ General reaction conditions: 30a $(1.0 \mathrm{mmol}), \mathbf{7 3 a}(1.5 \mathrm{mmol}),[\mathrm{Ru}](10 \mathrm{~mol} \%), \mathrm{AgSbF}_{6}(20 \mathrm{~mol} \%)$, additive (20 mol \%), $\mathrm{Ag}_{2} \mathrm{O}$ (1.0 equiv), DMF (3.0 mL), $110{ }^{\circ} \mathrm{C}, 20$ h. ${ }^{[\mathrm{b}]} \mathrm{By}{ }^{1} \mathrm{H}-\mathrm{NMR}$ using $\mathrm{CH}_{2} \mathrm{Br}_{2}$ as internal standard. ${ }^{[\mathrm{cc}]}$ Isolated yields. ${ }^{[\mathrm{d}]}$ In the absence of $\mathrm{AgSbF}_{6} \cdot{ }^{[\mathrm{e}]}\left[\left\{\mathrm{RuCl}_{2}(p \text {-cymene })\right\}_{2}\right](2.5 \mathrm{~mol} \%), \mathrm{AgSbF}_{6}(10 \mathrm{~mol} \%)$.

An extensive screening confirmed DMF as the solvent of choice, while other solvent systems gave inferior results under otherwise identical reaction conditions (Table 2).

Table 2: Effect of solvents. ${ }^{[a]}$

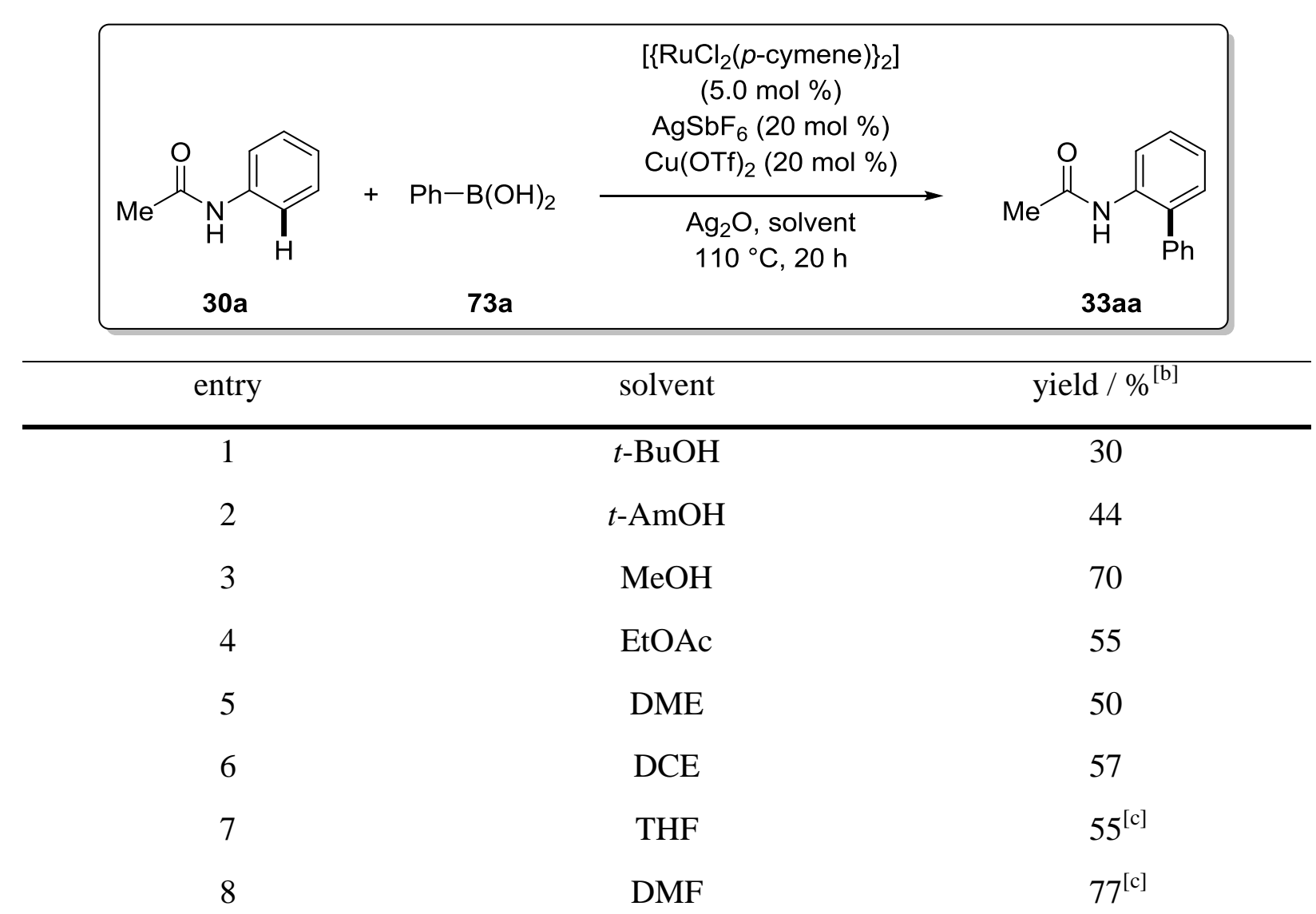




$\begin{array}{cc}9 & \mathrm{DMF} / \mathrm{MeOH} \\ 10 & 42^{[\mathrm{d}]} \\ \mathrm{DMF} / \mathrm{THF} & 65^{[\mathrm{d}]}\end{array}$

${ }^{\text {[a] }}$ General reaction conditions: $30 \mathbf{a}(1.0 \mathrm{mmol}), \mathbf{7 3 a}(1.5 \mathrm{mmol}),\left[\left\{\mathrm{RuCl}_{2}(p \text {-cymene })\right\}_{2}\right](5.0 \mathrm{~mol} \%), \mathrm{AgSbF}_{6}$ $(20 \mathrm{~mol} \%), \mathrm{Cu}(\mathrm{OTf})_{2}(20 \mathrm{~mol} \%), \mathrm{Ag}_{2} \mathrm{O}$ (1.0 equiv), solvent $(3.0 \mathrm{~mL}), 110{ }^{\circ} \mathrm{C}, 20 \mathrm{~h} .{ }^{[\mathrm{b}]} \mathrm{By}{ }^{1} \mathrm{H}-\mathrm{NMR}$ using $\mathrm{CH}_{2} \mathrm{Br}_{2}$ as internal standard. ${ }^{[\mathrm{c}]}$ Isolated yields. ${ }^{[\mathrm{d}]}$ Solvent mixture $(3.0 \mathrm{~mL}, 1: 1)$.

Extended testing of the terminal oxidants displayed $\mathrm{Ag}_{2} \mathrm{O}$ as most effective compared to other oxidants, which resulted in unsatisfactory yields of 33aa (Table 3).

Table 3: Effect of oxidants. ${ }^{[a]}$

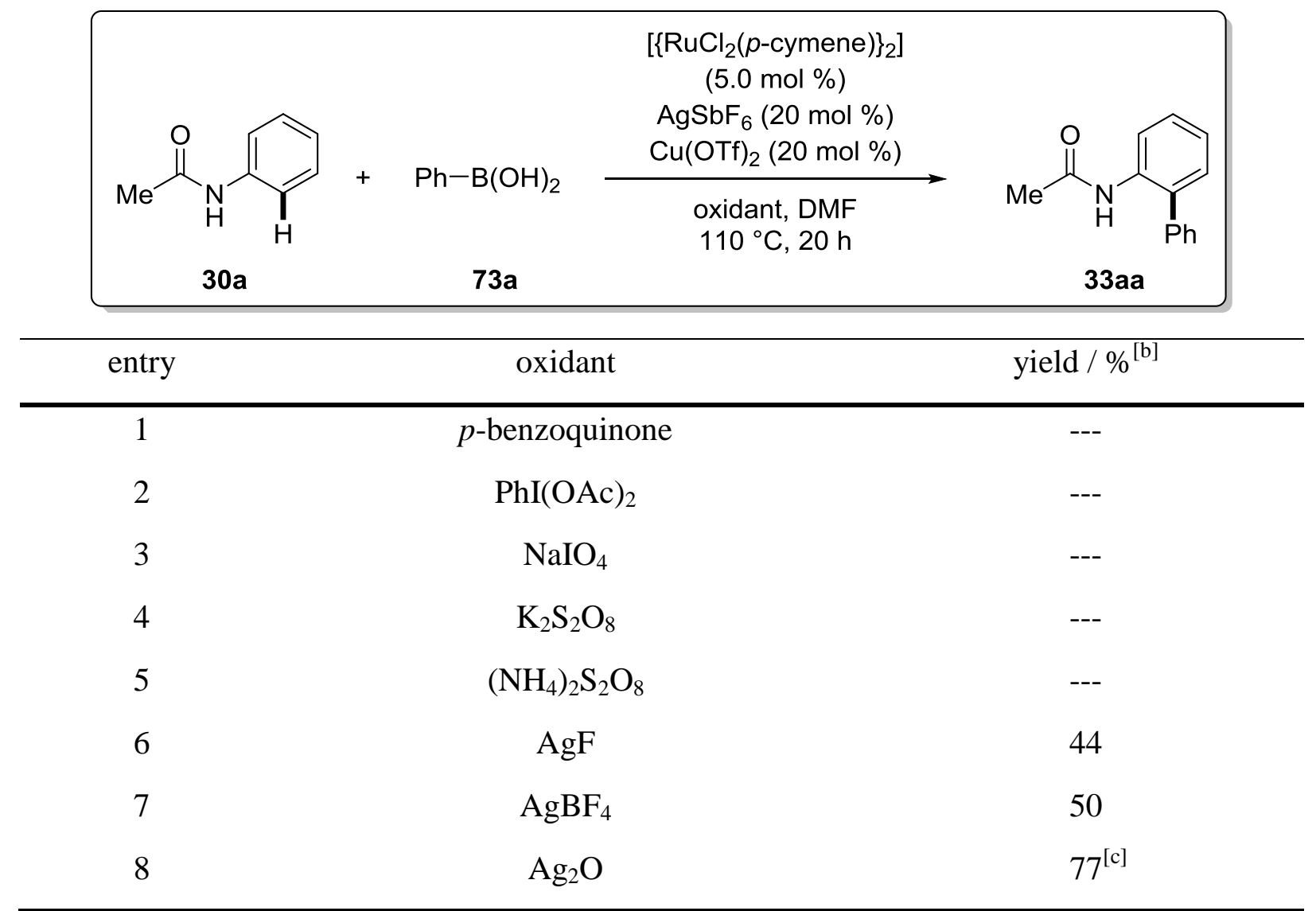

${ }^{\text {[a] }}$ General reaction conditions: 30a $(1.0 \mathrm{mmol}), \mathbf{7 3 a}(1.5 \mathrm{mmol}),\left[\left\{\mathrm{RuCl}_{2}(p \text {-cymene })\right\}_{2}\right](5.0 \mathrm{~mol} \%), \mathrm{AgSbF}_{6}$ $(20 \mathrm{~mol} \%), \mathrm{Cu}(\mathrm{OTf})_{2}(20 \mathrm{~mol} \%)$, oxidant (1.0 equiv), DMF $(3.0 \mathrm{~mL}), 110{ }^{\circ} \mathrm{C}, 20 \mathrm{~h} .{ }^{[\mathrm{b}]} \mathrm{By}{ }^{1} \mathrm{H}-\mathrm{NMR}$ using $\mathrm{CH}_{2} \mathrm{Br}_{2}$ as internal standard. ${ }^{[\mathrm{c}]}$ Isolated yields.

The most efficient mono-selective $\mathrm{C}-\mathrm{H}$ arylation on $\mathrm{N}$-phenylacetamide (30a) with phenylboronic acid (73a) as arylating reagent was achieved with $\left[\left\{\mathrm{RuCl}_{2}(p \text {-cymene) }\}_{2}\right]\right.$ as catalyst and $\mathrm{AgSbF}_{6}$, which generated in situ an active cationic ruthenium(II) precursor, $\mathrm{Cu}(\mathrm{OTf})_{2}$ as additive and $\mathrm{Ag}_{2} \mathrm{O}$ as terminal oxidant in DMF as solvent to afford the desired product 33aa in an excellent yield (Table 1, entry 15). 


\subsubsection{Influence of $N$-substituents on anilides}

Afterwards, the influence of different $N$-substituents on anilides $\mathbf{3 0}$ on the $\mathrm{C}-\mathrm{H}$ arylation was investigated (Table 4). The results showed that the acetyl group provided an unsurpassed result (entry 1). The sterically demanding $N$-substituted anilides 30b and 30c as well as the aryl substituted anilide 30d resulted in inferior outcomes (entries 2-4). Additionally, more electron-deficient anilides 30e and 30f were unsuccessfully subjected to the reaction conditions (entries 5 and 6). Furthermore, the tertiary anilide $\mathbf{3 0 g}$ was not effective, proving the necessity of the acidic $\mathrm{N}-\mathrm{H}$ moiety for the ortho- $\mathrm{C}-\mathrm{H}$ arylation (entry 7).

Table 4: Influence of $N$-substituents on anilides 30. ${ }^{\text {[a] }}$

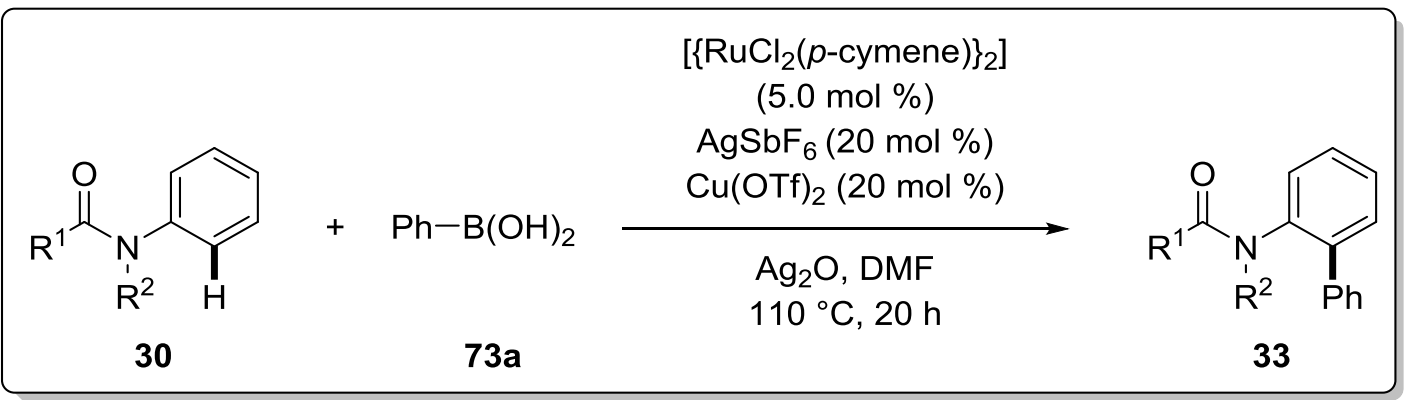

entry


6<smiles>CC(C)(C)OC(=O)Nc1ccccc1</smiles>

7<smiles>CC(=O)N(C)c1ccccc1</smiles>

$30 f$<smiles>CC(C)(C)OC(=O)Nc1ccccc1-c1ccccc1</smiles><smiles>[111In]</smiles>

$30 \mathrm{~g}$

33ga<smiles>CC(=O)N(C)c1ccccc1-c1ccccc1</smiles>

${ }^{[a]}$ General reaction conditions: $30(1.0 \mathrm{mmol}), \mathbf{7 3 a}(1.5 \mathrm{mmol}),\left[\left\{\mathrm{RuCl}_{2}(p \text {-cymene })\right\}_{2}\right](5.0 \mathrm{~mol} \%), \mathrm{AgSbF}_{6}$ $(20 \mathrm{~mol} \%), \mathrm{Cu}(\mathrm{OTf})_{2}(20 \mathrm{~mol} \%), \mathrm{Ag}_{2} \mathrm{O}\left(1.0\right.$ equiv), $\mathrm{DMF}(3.0 \mathrm{~mL}), 110{ }^{\circ} \mathrm{C}, 20 \mathrm{~h}$; isolated yields.

\subsubsection{Scope of $\mathrm{C}-\mathrm{H}$ arylation of acetanilides with boron-based arylating reagents}

With the optimized catalytic system in hand, the substrate scope of the site-selective $\mathrm{C}-\mathrm{H}$ arylation was successfully studied with the parent acetanilide 30a as well as the ortho-, metaand para-substituted anilides $\mathbf{3 0}$ bearing electron-donating or electron-withdrawing groups, respectively (Table 5). Thus, the electronic character of anilides $\mathbf{3 0}$ had no significant impact on the performance of the catalytic system. The desired products $\mathbf{3 3}$ were obtained in good yields with an excellent selective mono-arylation, even for para-substituted anilides $\mathbf{3 0}$. Intramolecular competition experiments with meta-substituted anilides 30i and 30m revealed a superb regioselectivity at the less sterically demanding C-6 position of the arene (entries 3 and 7).

Table 5: Scope of $\mathrm{C}-\mathrm{H}$ arylation of acetanilides $\mathbf{3 0}$ with phenylboronic acid (73a) ${ }^{[a]}$

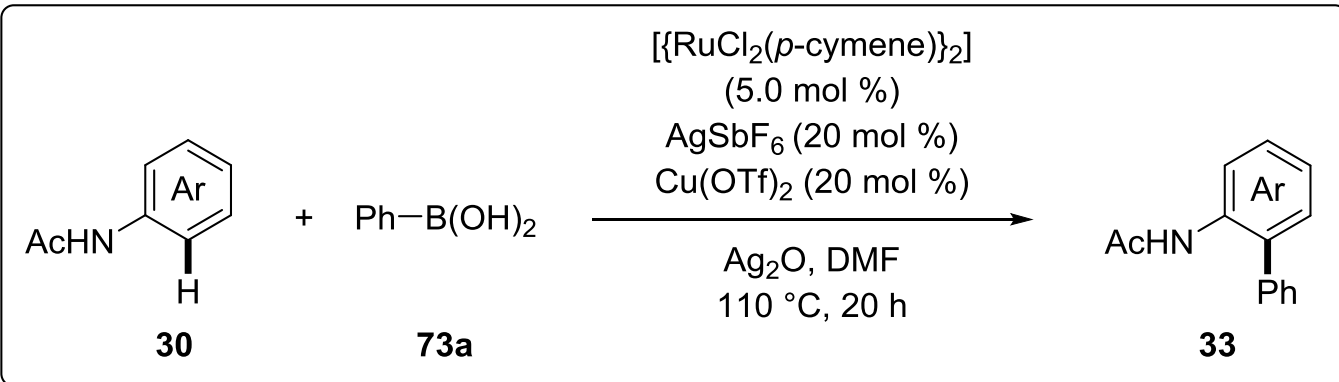

entry


3<smiles>Cc1cccc(N=CC(C)C)c1</smiles>

4<smiles>CCNc1ccc(C)cc1</smiles>

5<smiles>C=CNc1ccc(CC)cc1</smiles>

6<smiles>COc1ccc(NC(C)=O)cc1</smiles>

7<smiles>COc1cccc(N=C(C)C)c1</smiles>

8<smiles>ClC(Cl)=Nc1cccc2ccccc12</smiles>

9<smiles>CCNc1ccc(-c2ccccc2)cc1</smiles>

10<smiles>CC(C)Nc1ccc(O)cc1</smiles>

11<smiles>CCNc1ccc(F)cc1</smiles>

12<smiles>CCNc1ccc(Cl)cc1</smiles>

$30 \mathbf{i}$<smiles>Cc1ccc(-c2ccccc2)c(NC(C)C)c1</smiles>

33ia 78

30j<smiles>CCNc1ccc(C)cc1-c1ccccc1</smiles>

30k<smiles>CCc1ccc(N=CC(C)C)c(-c2ccccc2)c1</smiles>

33ka

301<smiles>CCNc1ccc(OC)cc1-c1ccccc1</smiles>

33la 76

30m<smiles>COc1ccc(-c2ccccc2)c(NC=C(C)Cl)c1</smiles>

33ma 72<smiles>CC(C)Nc1c(-c2ccccc2)ccc2ccccc12</smiles>

33na

29

30n

300<smiles>CCNc1ccc(-c2ccccc2)cc1-c1ccccc1</smiles>

33oa 54

30p<smiles>CC(C)Nc1ccc(O)cc1-c1ccccc1</smiles>

33pa

30q<smiles>Fc1ccc(N=CCl)c(-c2ccccc2)c1</smiles>

33qa 71

30r

33ra 
13<smiles>CCNc1ccc(Br)cc1</smiles>

14<smiles>C#CNc1ccc(C(=O)OC)cc1</smiles>

30s<smiles>ClC=CNc1ccc(Br)cc1-c1ccccc1</smiles>

33sa

$30 t$

33ta 58

${ }^{[\mathrm{a}]}$ General reaction conditions: $30(1.0 \mathrm{mmol}), \mathbf{7 3 a}(1.5 \mathrm{mmol}),\left[\left\{\mathrm{RuCl}_{2}(p \text {-cymene })\right\}_{2}\right](5.0 \mathrm{~mol} \%), \mathrm{AgSbF}_{6}$ $(20 \mathrm{~mol} \%), \mathrm{Cu}(\mathrm{OTf})_{2}(20 \mathrm{~mol} \%), \mathrm{Ag}_{2} \mathrm{O}\left(1.0\right.$ equiv), DMF $(3.0 \mathrm{~mL}), 110{ }^{\circ} \mathrm{C}, 20 \mathrm{~h}$; isolated yields

The ample scope demonstrated the high chemoselectivity by fully tolerating valuable electrophilic functional groups, including fluoro, chloro, bromo, hydroxyl, ether or ester substituents, indicating great potential for further postsynthetic transformations. The electronic nature of the arylboronic acids $\mathbf{7 3}$ did not play a crucial role (Table 6). Both electron-rich and electron-poor boronic acids $\mathbf{7 3}$ provided the desired products $\mathbf{3 3}$ in a siteselective manner in high yields.

Table 6: Scope of $\mathrm{C}-\mathrm{H}$ arylation of acetanilides $\mathbf{3 0}$ with arylboronic acids $\mathbf{7 3}$. $^{\text {[a] }}$

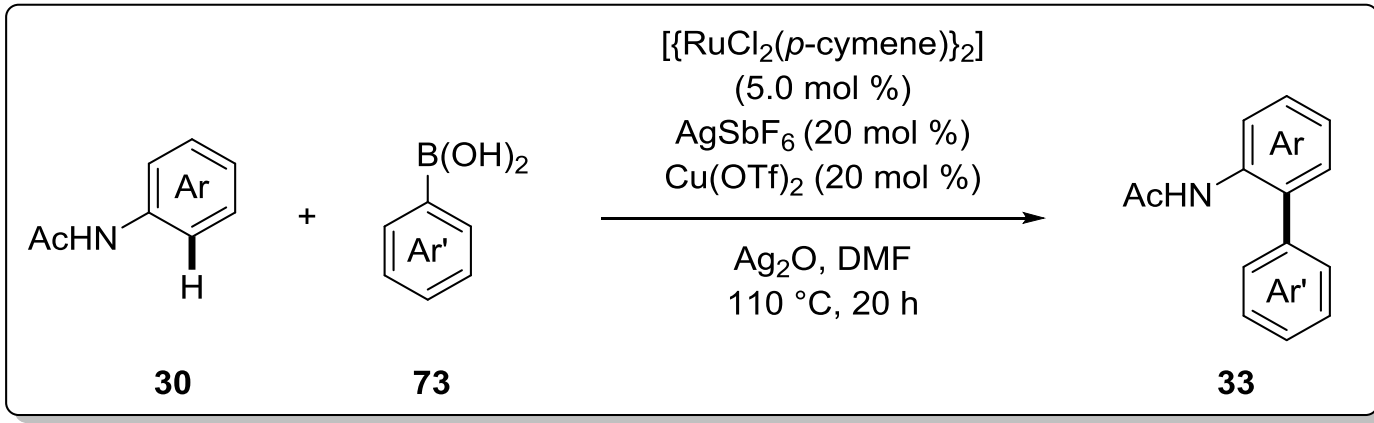

entry


3<smiles>CC=Cc1ccccc1</smiles>

30a<smiles>COc1ccc(Br)cc1</smiles>

73d

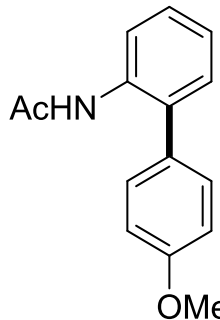

4<smiles>ClC=Cc1ccccc1</smiles>

30a<smiles>COc1ccc2c(c1)OCO2</smiles>

$73 e$

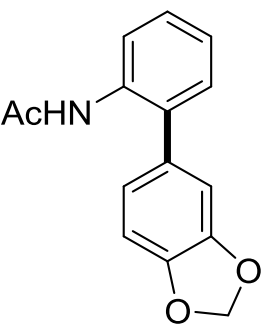

$73 f$<smiles>CC(C)Nc1ccccc1-c1ccc(Br)cc1</smiles>

$73 g$<smiles>CC(C)Nc1ccccc1-c1ccc(Cl)cc1</smiles>

33ag

70

73h<smiles>CC(C)Nc1ccccc1-c1cc(F)c(F)c(F)c1</smiles>

33ah $68,54^{[\mathrm{b}]}$
8<smiles>CC(C)=Nc1ccc(F)cc1</smiles>

$30 a$<smiles>Oc1cc(F)c(F)c(Br)c1</smiles>

30q<smiles>Oc1cc(Br)ccc1Cl</smiles>

33ad

33ae 68

33af 63

\section{3}

$$
0
$$

7<smiles>ClC=Nc1ccccc1</smiles><smiles>CC(C)Nc1ccc(F)cc1-c1ccc(Cl)c(Cl)c1</smiles>

\footnotetext{
${ }^{[a]}$ General reaction conditions: $30(1.0 \mathrm{mmol}), 73(1.5 \mathrm{mmol}),\left[\left\{\mathrm{RuCl}_{2}(p \text {-cymene })\right\}_{2}\right](5.0 \mathrm{~mol} \%), \mathrm{AgSbF}_{6}$
} $(20 \mathrm{~mol} \%), \mathrm{Cu}(\mathrm{OTf})_{2}(20 \mathrm{~mol} \%), \mathrm{Ag}_{2} \mathrm{O}$ (1.0 equiv), DMF $(3.0 \mathrm{~mL}), 110{ }^{\circ} \mathrm{C}, 20 \mathrm{~h}$; isolated yields. ${ }^{[\mathrm{b}]} \mathbf{3 0 a}$ $(8.0 \mathrm{mmol}), \mathbf{7 3 h}(12 \mathrm{mmol})$. 
Of particular note are the key intermediates 33ag, 33ah and 33qi (entries 6-8), used in the manufacture of Boscalid (1), Fluxapyroxad (2) and Bixafen (3) after removal of the acyl group (Scheme 24). ${ }^{[137-139]}$ In addition, a gram-scale synthesis was realised with this practical method for the valuable building block 33ah in a comparable yield (entry 7).

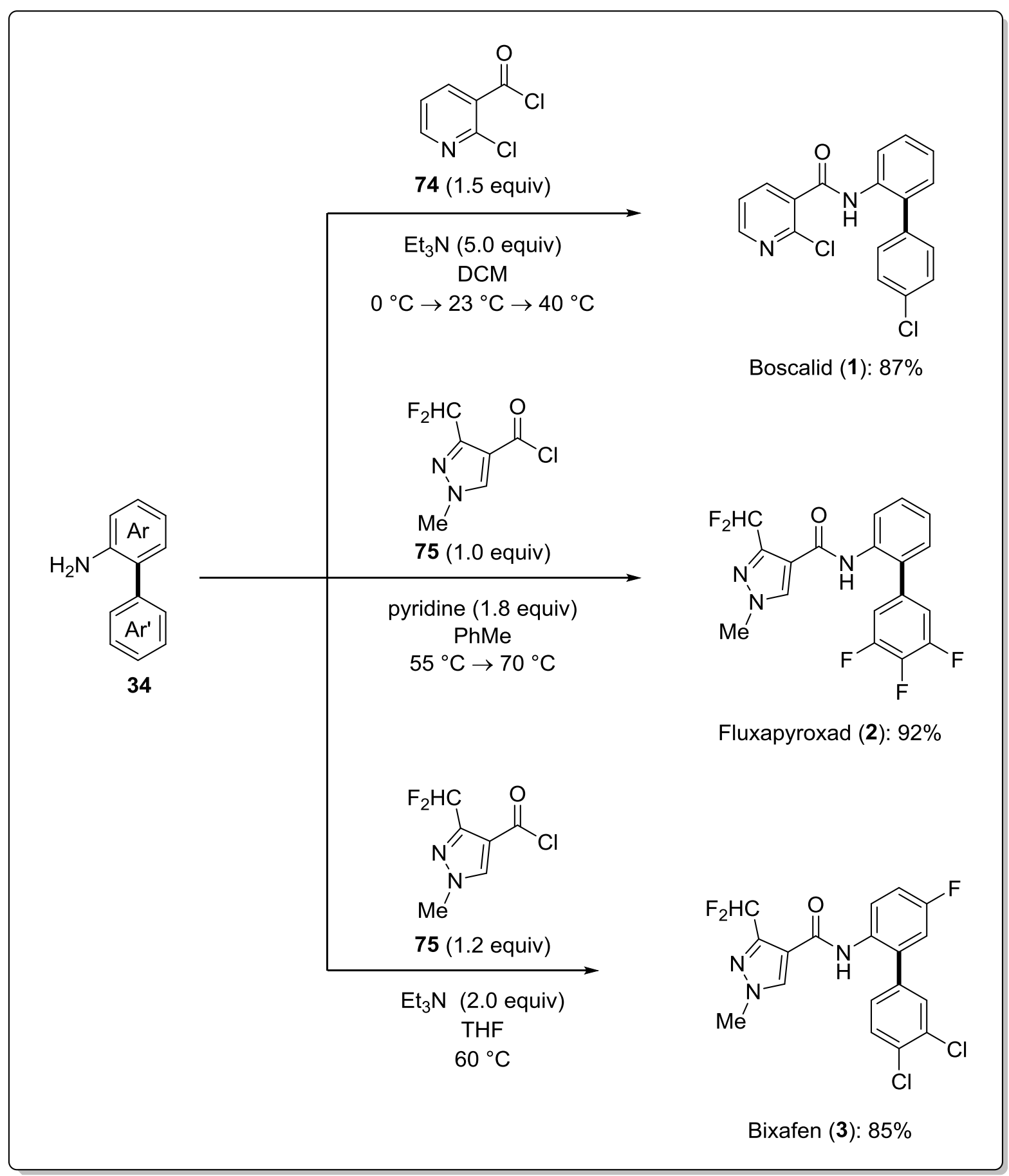

Scheme 24: Syntheses of important antifungal agrochemicals. 
The substrate scope was successfully completed with borinic acids $\mathbf{7 6}$ and potassium trifluoroborates $\mathbf{7 7}$ as arylating reagents. At this stage, conventional boron-based arylating reagents are limited to boronic acids $\mathbf{7 3}$ and boronates for ruthenium-catalyzed $\mathrm{C}-\mathrm{H}$ functionalization. ${ }^{[25,26,75,76,140,141]}$ For that reason, the use of borinic acids $\mathbf{7 6}$ reinforced the utility of this catalytic system (Table 7).

Table 7: Scope of C-H arylation of acetanilides $\mathbf{3 0}$ with arylborinic acids $\mathbf{7 6}$. $^{\text {[a] }}$

\begin{tabular}{|c|c|c|c|}
\hline & & $\begin{array}{c}{\left[\left\{\operatorname{RuCl}_{2}(p-\text { cymene })\right\}_{2}\right]} \\
(5.0 \mathrm{~mol} \%) \\
\mathrm{AgSbF}_{6}(20 \mathrm{~mol} \%) \\
\mathrm{Cu}(\mathrm{OTf})_{2}(20 \mathrm{~mol} \%)\end{array}$ & $\mathrm{AcHN}^{-}$ \\
\hline $\mathrm{AcHN}^{-}$ & $\left(\mathrm{Ar}_{2}^{\mathrm{BOH}}\right.$ & $\begin{array}{l}\mathrm{Ag}_{2} \mathrm{O}, \mathrm{DMF} \\
110^{\circ} \mathrm{C}, 20 \mathrm{~h}\end{array}$ & \\
\hline 30 & 76 & & 33 \\
\hline
\end{tabular}

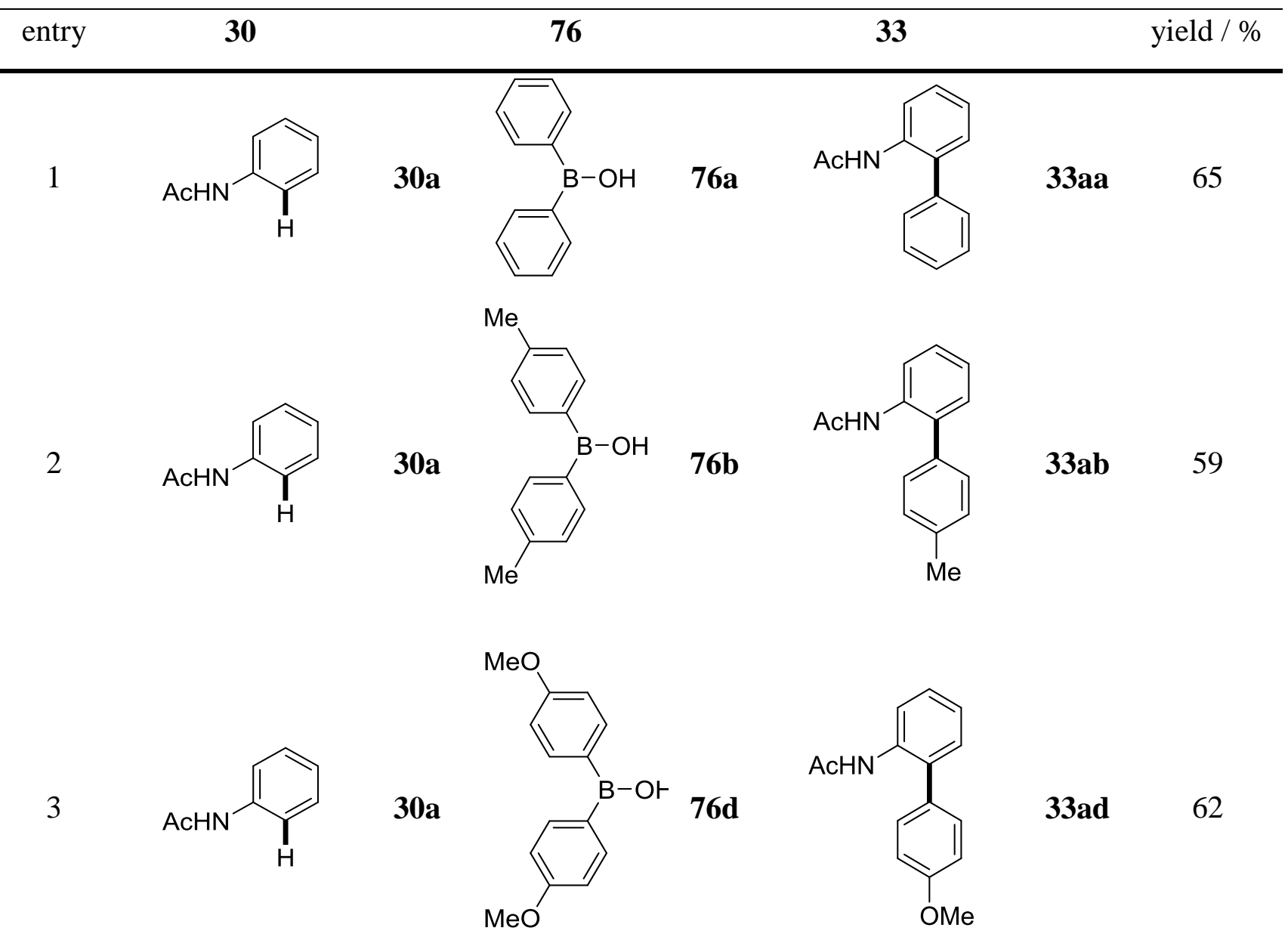


4<smiles>Cc1cccc(NC(C)C)c1</smiles>

30i<smiles>Cc1ccc(B(O)c2ccc(C)cc2)cc1</smiles>

30m<smiles>CCNc1ccccc1</smiles>

30h

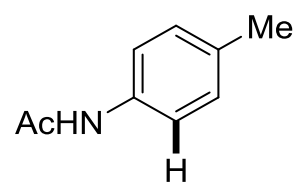

7<smiles>COc1ccc(NC(C)C)cc1</smiles><smiles>COc1ccc(B(O)c2ccc(C)cc2)cc1</smiles><smiles>COc1ccc(B(O)c2ccc(C)cc2)cc1</smiles>

$76 b$<smiles>CCNc1cc(C)ccc1-c1ccc(C)cc1</smiles>

33ib

61<smiles>CC=CNc1cc(OC)ccc1-c1ccc(C)cc1</smiles>

$33 m b$

64

$76 b$

$76 b$

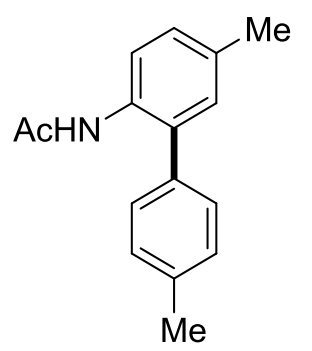

33hb<smiles>COc1ccc(NC=CC(C)C)c(-c2ccc(C)cc2)c1</smiles>

33lb

${ }^{[a]}$ General reaction conditions: $30(1.0 \mathrm{mmol}), \mathbf{7 6}(3.0 \mathrm{mmol}),\left[\left\{\mathrm{RuCl}_{2}(p \text {-cymene })\right\}_{2}\right](5.0 \mathrm{~mol} \%), \mathrm{AgSbF}_{6}$ (20 mol \%), $\mathrm{Cu}(\mathrm{OTf})_{2}(20 \mathrm{~mol} \%), \mathrm{Ag}_{2} \mathrm{O}$ (1.0 equiv), $\mathrm{DMF}(3.0 \mathrm{~mL}), 110{ }^{\circ} \mathrm{C}, 20 \mathrm{~h}$; isolated yields.

Potassium trifluoroborates $\mathbf{7 7}$ are effective surrogates to boronic acids $\mathbf{7 3}$ in metal-catalyzed cross-coupling reactions, ${ }^{[142-144]}$ which were also successfully subjected to this reaction conditions (Table 8). 
Table 8: Scope of $\mathrm{C}-\mathrm{H}$ arylation of acetanilides $\mathbf{3 0}$ with potassium aryltrifluoroborates $\mathbf{7 7}{ }^{\text {[a] }}$

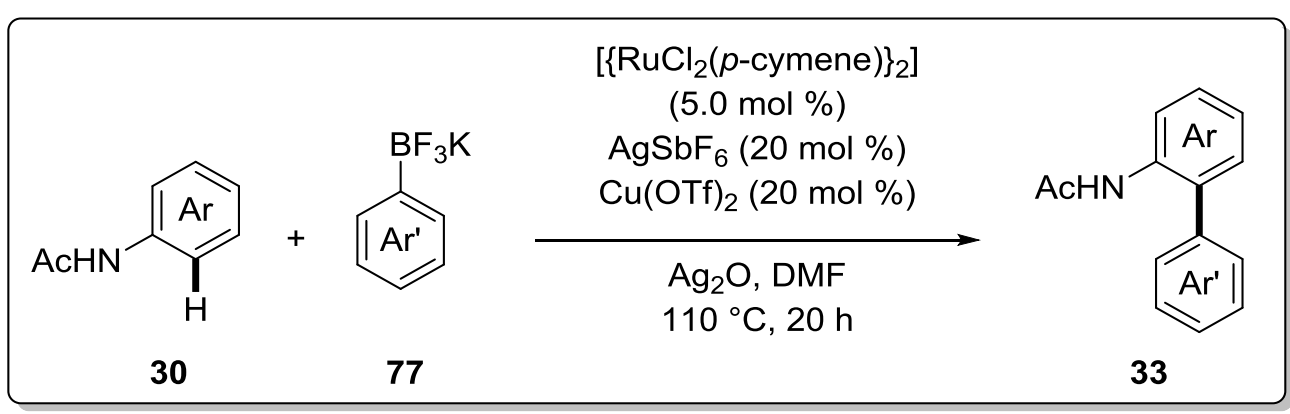

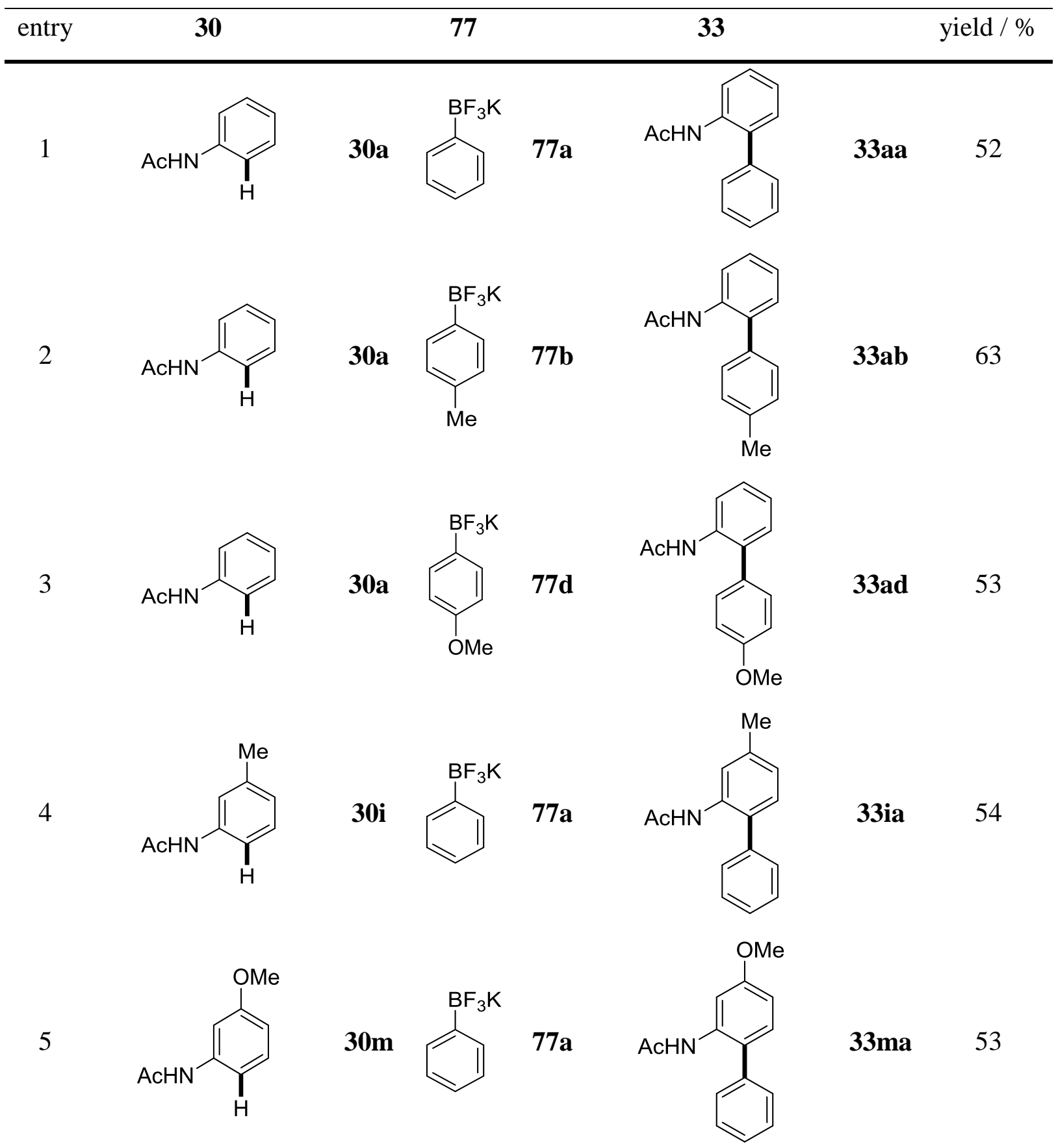


6

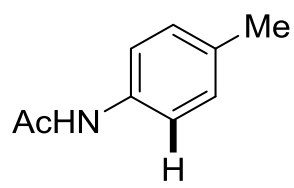

30h<smiles>Cc1ccc(C(F)(F)F)cc1</smiles>

$77 b$

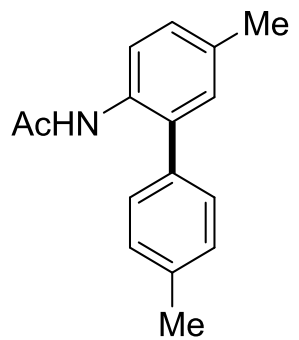

33hb

55

$77 b$<smiles>COc1ccc(NC(C)C)c(-c2ccc(C)cc2)c1</smiles>

33lb 56

${ }^{[\mathrm{a}]}$ General reaction conditions: 30 (1.0 mmol), 77 (3.0 mmol), [\{ $\mathrm{RuCl}_{2}(p$-cymene $\left.\left.)\right\}_{2}\right]\left(5.0 \mathrm{~mol}_{\%}\right), \mathrm{AgSbF}_{6}$ $(20 \mathrm{~mol} \%), \mathrm{Cu}(\mathrm{OTf})_{2}(20 \mathrm{~mol} \%), \mathrm{Ag}_{2} \mathrm{O}\left(1.0\right.$ equiv), $\mathrm{DMF}(3.0 \mathrm{~mL}), 110{ }^{\circ} \mathrm{C}, 20 \mathrm{~h}$; isolated yields

\subsubsection{Mechanistic studies}

\subsubsection{Kinetic isotope effect (KIE)}

Two independent ruthenium-catalyzed $\mathrm{C}-\mathrm{H}$ arylations with unlabelled substrate 30a and isotopically labelled substrate $\left[\mathrm{D}_{5}\right]-\mathbf{3 0 a}$ were conducted respectively to determine an intermolecular kinetic isotope effect $(\mathrm{KIE})$ of $k_{\mathrm{H}} / k_{\mathrm{D}} \approx 1.5$ by means of the initial rates, which indicates that the $\mathrm{C}-\mathrm{H}$ activation is not involved in the rate-determining step (Scheme 25).

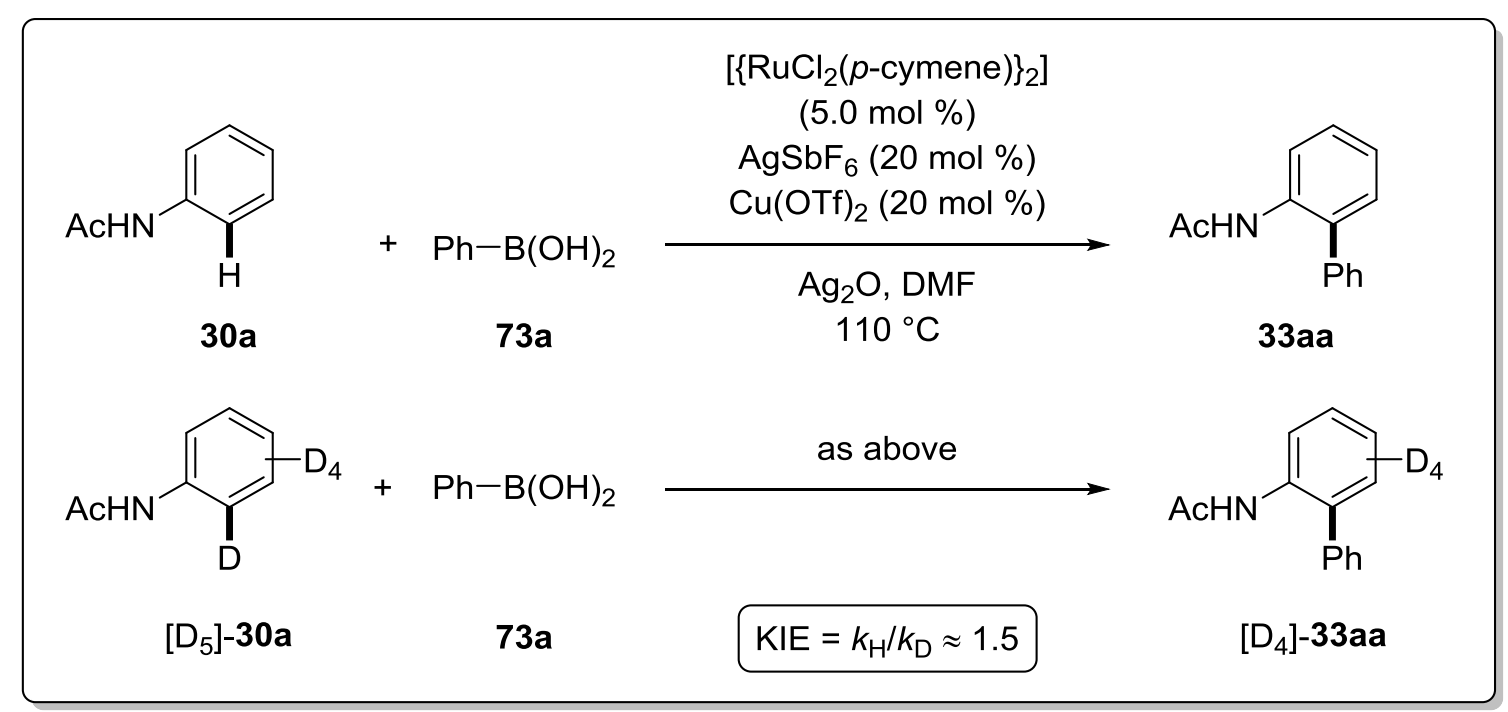

Scheme 25: Intermolecular kinetic isotope effect study by two independent reactions. 


\subsubsection{H/D Exchange experiments}

The reversible nature of the $\mathrm{C}-\mathrm{H}$ ruthenation step in this direct arylation was confirmed through two H/D exchange experiments in the presence of methanol- $\mathrm{d}_{4}$ as co-solvent. The first experiment was conducted in the absence of a boron-based arylating reagent and revealed a significant H/D scrambling, exclusively in the ortho-position of the reisolated acetanilide $\left[\mathrm{D}_{n}\right]$-30l (Scheme 26a). The second reaction was performed under the standard conditions. Once again, a notable amount of deuterium incorporation in the ortho-position of the recovered starting material $\left[\mathrm{D}_{n}\right]-\mathbf{3 0 l}$ and the product $\left[\mathrm{D}_{n}\right]$-33la was recognized (Scheme $26 \mathrm{~b}$ ).

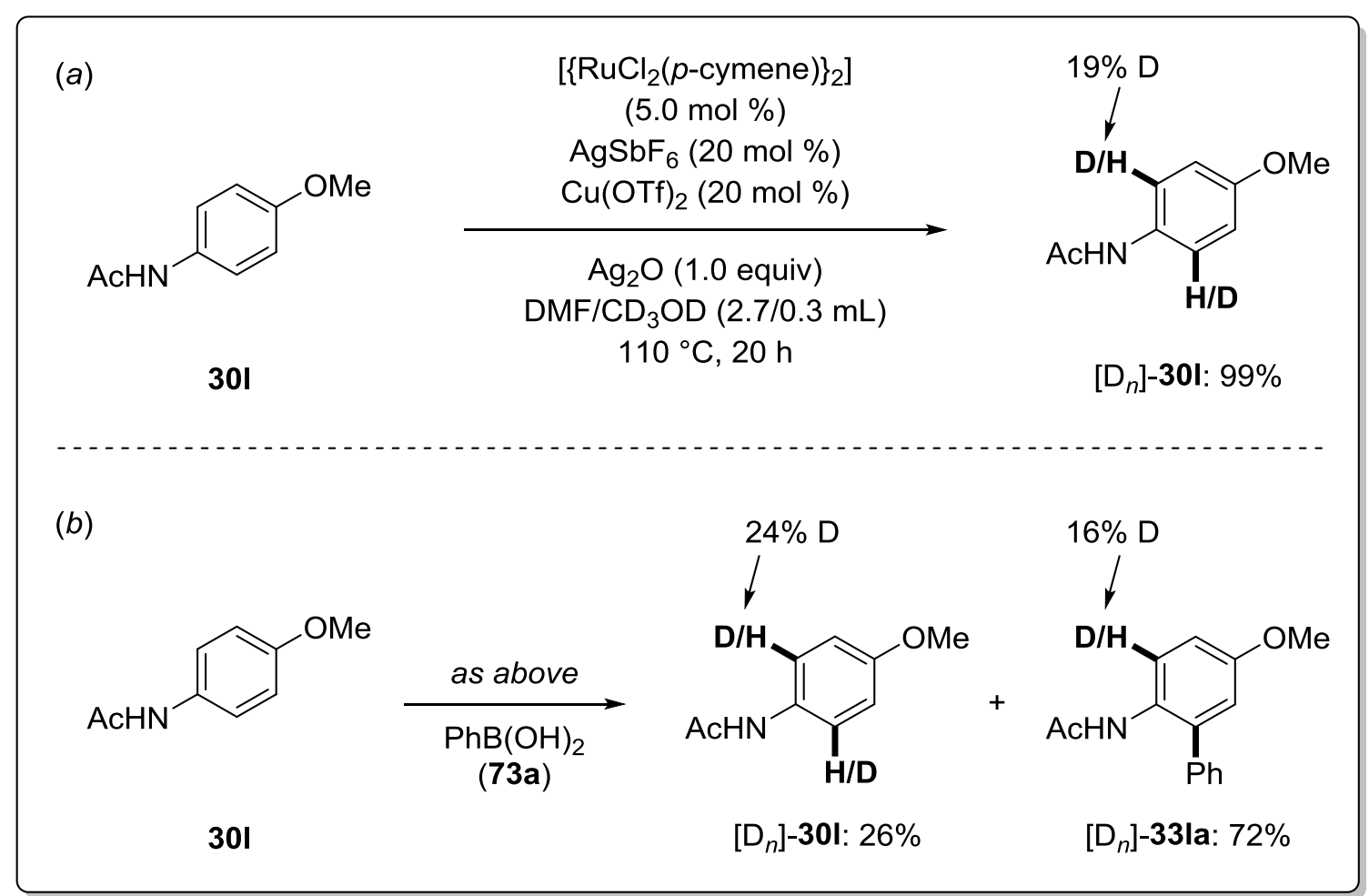

Scheme 26: H/D Exchange experiments with methanol- $\mathrm{d}_{4}$ as co-solvent.

\subsubsection{Proposed catalytic cycle}

A postulated catalytic cycle for the ruthenium(II)-catalyzed $\mathrm{C}-\mathrm{H}$ arylation of anilides $\mathbf{3 0}$ is outlined in Scheme 27. The first step is the in situ formation of the active cationic ruthenium(II) precursor 78. The carbonyl oxygen of the anilide $\mathbf{3 0}$ coordinates to the cationic ruthenium(II) species $\mathbf{7 8}$ to provide ruthenium complex 79. The reversible triflate-assisted ortho- $\mathrm{C}-\mathrm{H}$ bond ruthenation is facilitated via a six-membered inner-sphere concerted ruthenation-deprotonation transition state $\mathbf{8 0}$, delivering the six-membered ruthena(II)cycle $\mathbf{8 1}$ 
as a key intermediate. ${ }^{[7]}$ Subsequently, an irreversible transmetalation by the boron-based arylating reagent accelerated through $\mathrm{Ag}_{2} \mathrm{O}$ acting as base supplies ruthenium intermediate 82. The final step affords the desired ortho monoarylated product $\mathbf{3 3}$ by reductive elimination, while reoxidation of the ruthenium(0) intermediate in the presence of $\mathrm{Cu}(\mathrm{OTf})_{2}$ and $\mathrm{Ag}^{+}$ regenerates the active ruthenium(II) catalyst $\mathbf{7 8}$ to fulfill the catalytic cycle. ${ }^{[25]}$

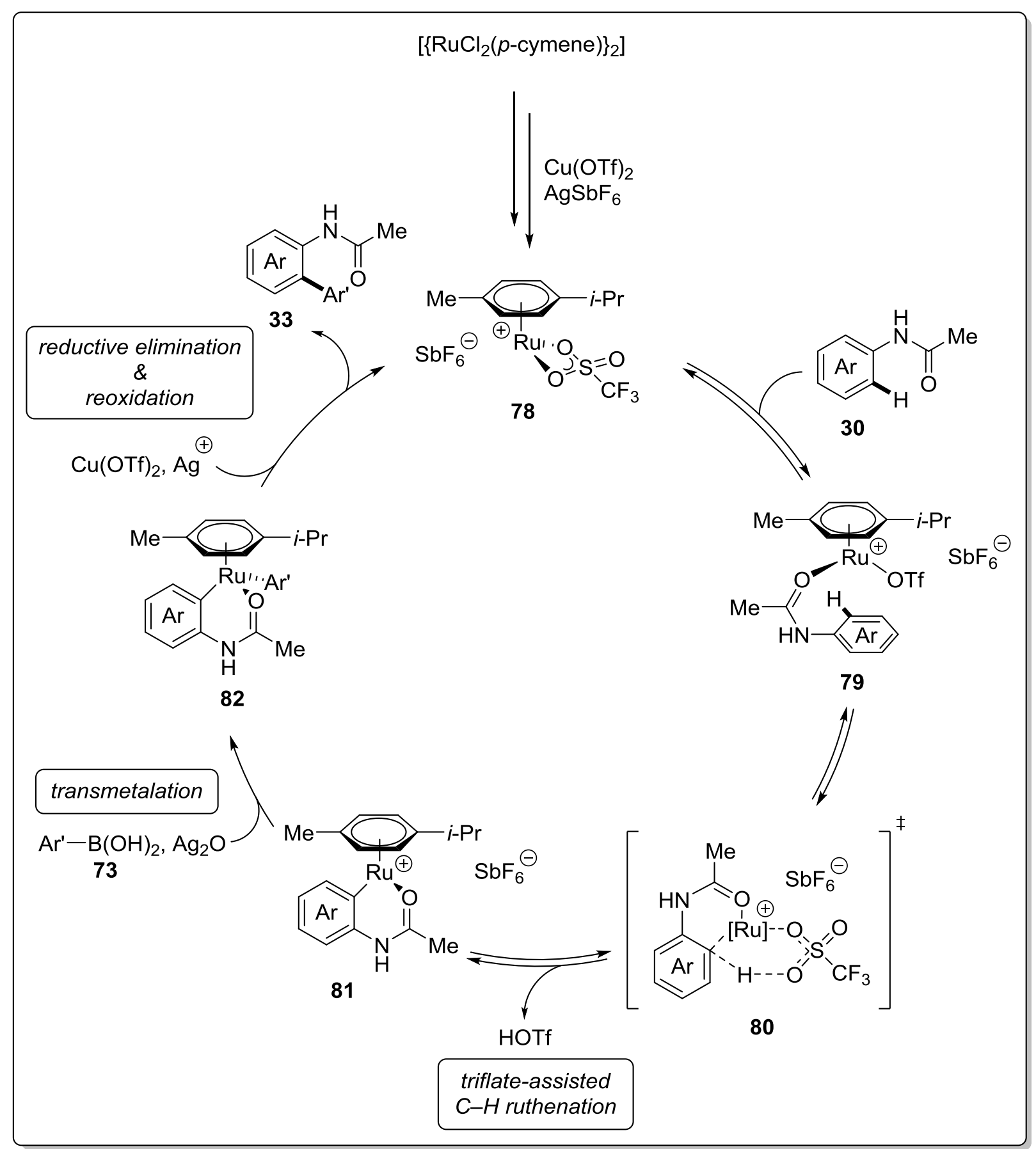

Scheme 27: Postulated catalytic cycle for ruthenium(II)-catalyzed C-H arylation of anilides 30. 


\subsection{Ruthenium(II)-catalyzed $\mathrm{C}-\mathrm{H}$ arylation of azoarenes by carboxylate assistance}

\subsubsection{Optimization of $\mathrm{C}-\mathrm{H}$ arylation of azoarene 13a with aryl bromide 52a}

The development of the catalytic reaction commenced with a thorough investigation of several reaction conditions on the azoarene 13a providing the desired $\mathrm{C}-\mathrm{H}$ arylated product 83aa (Tables 9-11). Initial studies revealed $\left[\left\{\mathrm{RuCl}_{2}(p \text {-cymene) }\}_{2}\right]\right.$ as the superior catalyst, whereas the $\mathrm{C}-\mathrm{H}$ functionalization did not proceed in the absence of a ruthenium source (Table 9, entry 1). The testing of various pre-ligands disclosed $\mathrm{MesCO}_{2} \mathrm{H}^{[7,15]}$ as the most suitable co-catalytic additive (entries 2-11). Performing the reaction with other carboxylic acids or different co-catalysts, such as phosphines, ${ }^{[7,120-122]}$ secondary phosphine oxides $(\mathrm{SPOs})^{[7,103,104]}$ or phosphoric acid diester $(\mathrm{PhO}){ }_{2} \mathrm{P}(\mathrm{O}) \mathrm{OH}^{[7,110]}$ provided inferior yields. The optimal loading of $\mathrm{MesCO}_{2} \mathrm{H}$ was found to be $30 \mathrm{~mol} \%$ but could also be reduced without a substantial decrease in reactivity (entries 11-12).

Table 9: Effect of additives. ${ }^{[\mathrm{a}]}$

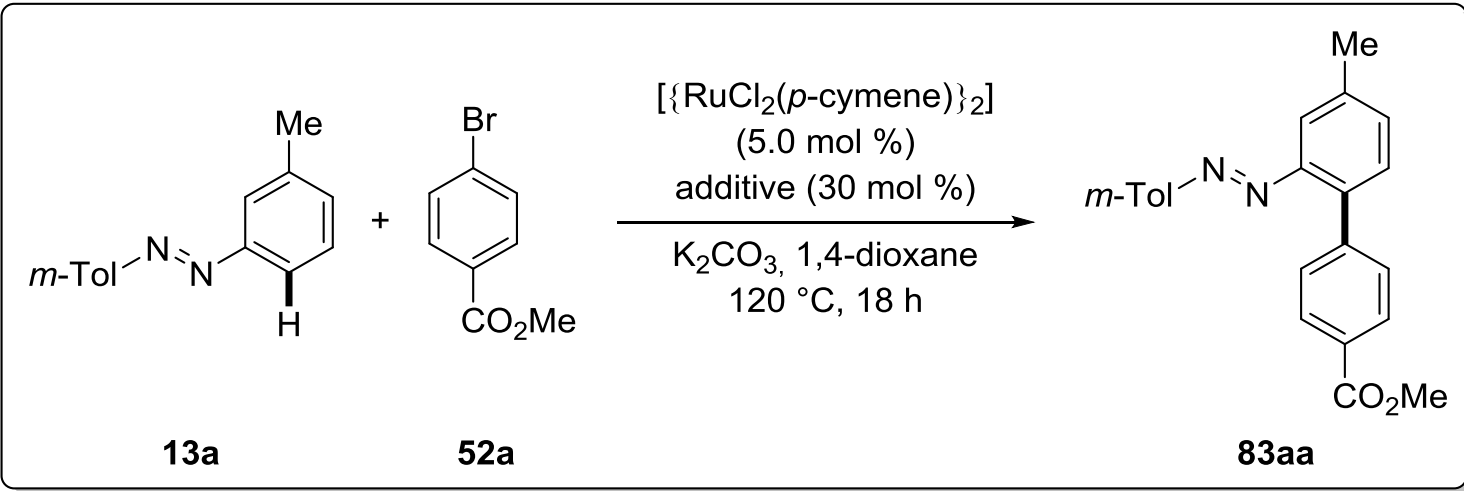

\begin{tabular}{ccc}
\hline entry & additive & yield / \% \\
\hline 1 & $\mathrm{MesCO}_{2} \mathrm{H}$ & - -- $^{[\mathrm{b}]}$ \\
2 & $\mathrm{PPh}_{3}$ & 44 \\
3 & $t$ - $\mathrm{BuPhP}(\mathrm{O}) \mathrm{H}$ & 43 \\
4 & $(\mathrm{PhO})_{2} \mathrm{P}(\mathrm{O}) \mathrm{OH}$ & 74 \\
5 & $\mathrm{KPF}_{6}$ & 75 \\
6 & acetamide & 64 \\
7 & $\mathrm{KOAc}$ & 79
\end{tabular}


8

9

10

11

12
$\mathrm{AcOH}$

$t-\mathrm{BuCO}_{2} \mathrm{H}$

1- $\mathrm{AdCO}_{2} \mathrm{H}$

$\mathrm{MesCO}_{2} \mathrm{H}$

$\mathrm{MesCO}_{2} \mathrm{H}$
37

76

45

87

$83^{[\mathrm{c}]}$

${ }^{[a]}$ General reaction conditions: $13 \mathbf{a}(1.0 \mathrm{mmol}), \mathbf{5 2 a}(0.50 \mathrm{mmol}),\left[\left\{\mathrm{RuCl}_{2}(p \text {-cymene })\right\}_{2}\right](5.0 \mathrm{~mol} \%)$, additive $(30 \mathrm{~mol} \%), \mathrm{K}_{2} \mathrm{CO}_{3}(1.0 \mathrm{mmol}), 1,4$-dioxane $(2.0 \mathrm{~mL}), 120{ }^{\circ} \mathrm{C}, 18 \mathrm{~h}$; isolated yields. ${ }^{[\mathrm{b}]}$ In the absence of $\left[\left\{\mathrm{RuCl}_{2}(p \text {-cymene })\right\}_{2}\right]$. ${ }^{[\mathrm{c}]} \mathrm{MesCO}_{2} \mathrm{H}(15 \mathrm{~mol} \%)$.

Among the solvents 1,4-dioxane emerged as the most effective, while the use of THF, MTBE, DME, $t$-AmOH, DCE, toluene or $o$-xylene delivered lower yields (Table 10).

Table 10: Effect of solvents. ${ }^{[a]}$

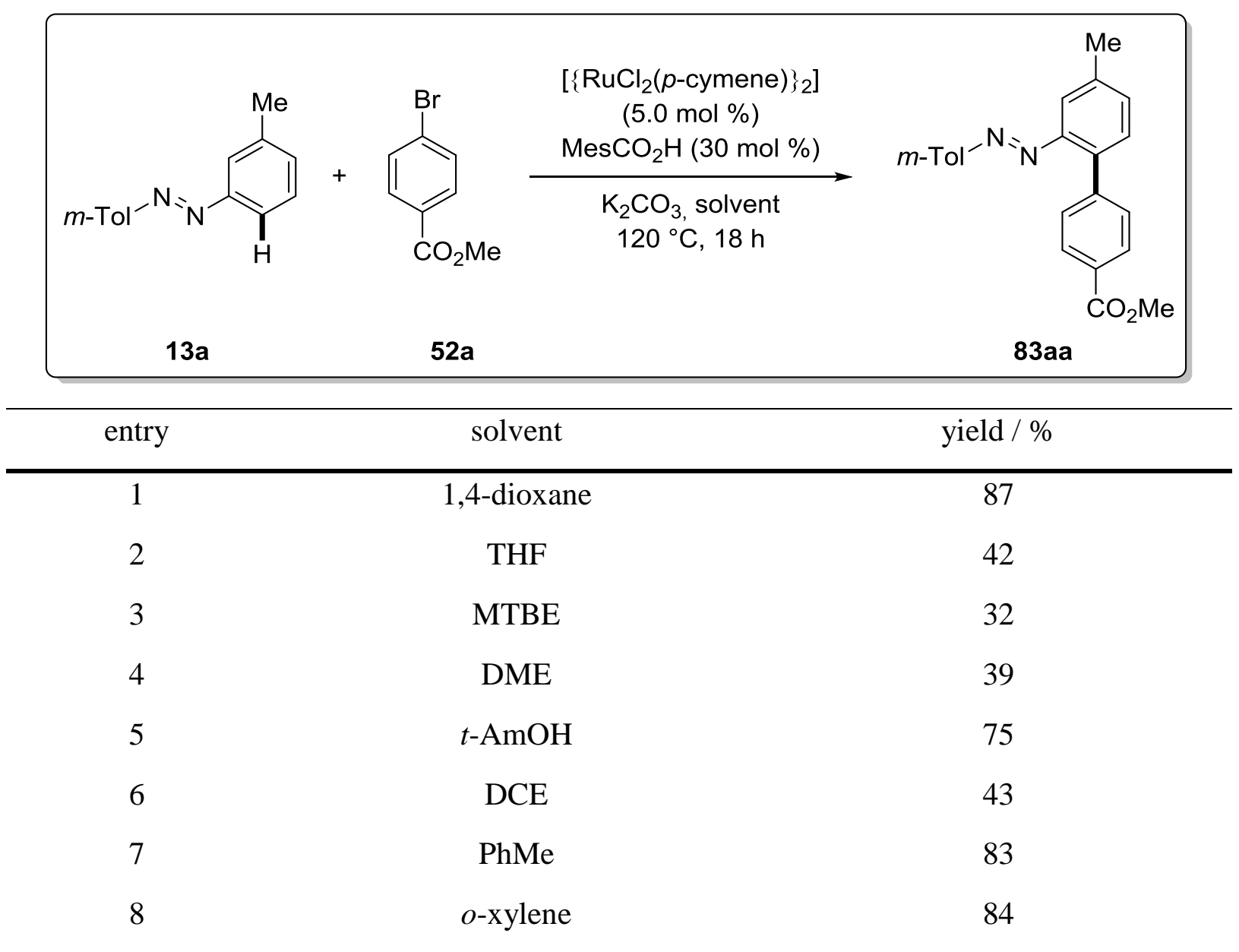

${ }^{\text {[a] }}$ General reaction conditions: $13 a(1.0 \mathrm{mmol}), \mathbf{5 2 a}(0.50 \mathrm{mmol}),\left[\left\{\mathrm{RuCl}_{2}(p \text {-cymene })\right\}_{2}\right](5.0 \mathrm{~mol} \%), \mathrm{MesCO}_{2} \mathrm{H}$ $(30 \mathrm{~mol} \%), \mathrm{K}_{2} \mathrm{CO}_{3}(1.0 \mathrm{mmol})$, solvent $(2.0 \mathrm{~mL}), 120^{\circ} \mathrm{C}, 18 \mathrm{~h}$; isolated yields. 
Several bases were probed and $\mathrm{K}_{2} \mathrm{CO}_{3}$ accomplished the best result (Table 11). The utilization of $\mathrm{Ag}_{2} \mathrm{CO}_{3}, \mathrm{Cs}_{2} \mathrm{CO}_{3}$ or $\left(\mathrm{NH}_{4}\right)_{2} \mathrm{CO}_{3}$ as bases failed to deliver the desired product 83aa under otherwise identical reaction conditions (entries 3-5). Furthermore, the application of KOAc and $\mathrm{K}_{3} \mathrm{PO}_{4}$ was not successfully implemented (entries 6 and 7), which revealed that the combination of the carbonate moiety and the potassium cation plays a crucial role for this $\mathrm{C}-\mathrm{H}$ transformation. ${ }^{[154]}$

Table 11: Effect of bases. ${ }^{[a]}$

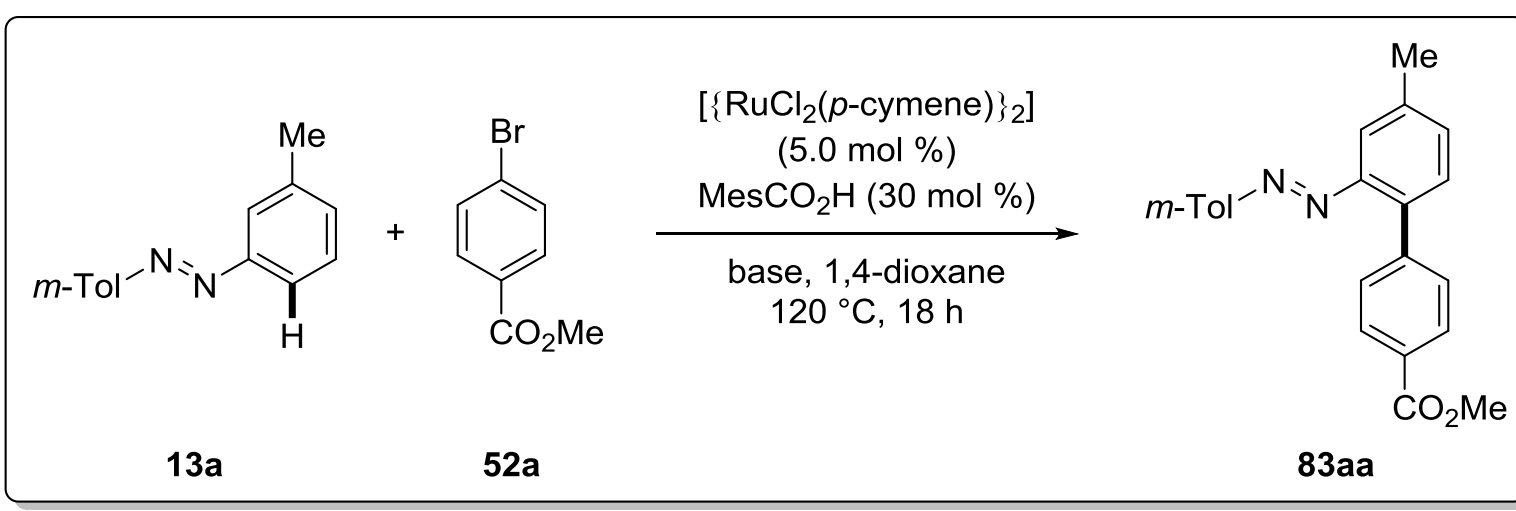

\begin{tabular}{ccc}
\hline entry & base & yield / \% \\
\hline 1 & $\mathrm{~K}_{2} \mathrm{CO}_{3}$ & 87 \\
2 & $\mathrm{Na}_{2} \mathrm{CO}_{3}$ & 75 \\
3 & $\mathrm{Ag}_{2} \mathrm{CO}_{3}$ & 0 \\
4 & $\mathrm{Cs}_{2} \mathrm{CO}_{3}$ & 0 \\
5 & $\left(\mathrm{NH}_{4}\right)_{2} \mathrm{CO}_{3}$ & 0 \\
6 & $\mathrm{KOAc}$ & 23 \\
7 & $\mathrm{~K}_{3} \mathrm{PO}_{4}$ & 0 \\
8 & $\mathrm{CsOPiv}$ & 0 \\
\hline
\end{tabular}

${ }^{[a]}$ General reaction conditions: 13a $(1.0 \mathrm{mmol}), \mathbf{5 2 a}(0.50 \mathrm{mmol}),\left[\left\{\mathrm{RuCl}_{2}(p \text {-cymene })\right\}_{2}\right](5.0 \mathrm{~mol} \%), \mathrm{MesCO}_{2} \mathrm{H}$ (3 mol \%), base $(1.0 \mathrm{mmol}), 1,4$-dioxane $(2.0 \mathrm{~mL}), 120^{\circ} \mathrm{C}, 18 \mathrm{~h}$; isolated yields. 


\subsubsection{Scope of $\mathrm{C}-\mathrm{H}$ arylation of azoarenes with (hetero)aryl halides}

Under the optimal reaction conditions, a representative range of symmetrical azoarenes $\mathbf{1 3}$ exhibited a high reactivity in this chemo- and site-selective $\mathrm{C}-\mathrm{H}$ functionalization with (hetero)aryl halides $\mathbf{6 3}$ providing the appropriate biaryl products $\mathbf{8 3}$ in moderate to excellent yields (Table 12). The ruthenium(II) catalytic system demonstrated in intramolecular competition experiments with meta-substituted azoarenes 13a and 13e - 13g an expedient siteselectivity at the less hindered C-6 position of the arene (entries 6-21). Several aryl electrophiles $\mathbf{5 2}$ were used and featured only a minor impact concerning the electronic nature of the aromatic moiety. Interestingly, aryl iodide 31a proved to be compatible with the system in an outstanding yield (entry 6). The $\mathrm{C}-\mathrm{H}$ transformation was chemoselective for valuable electrophilic functional groups, such as chloride, amine, ether, aldehyde, enolizable ketone, ester, cyano or nitro substituents, providing opportunities for further late-stage derivatization. Performing this $\mathrm{C}-\mathrm{H}$ activation with electron-deficient azoarenes $\mathbf{1 3}$ resulted in no conversion (entries 22-26), illustrating that the electronic character of differently substituted azoarenes $\mathbf{1 3}$ is a dominant factor in this process.

Table 12: Scope of $\mathrm{C}-\mathrm{H}$ arylation of azoarenes 13 with aryl bromides 52 . $^{[\mathrm{a}]}$

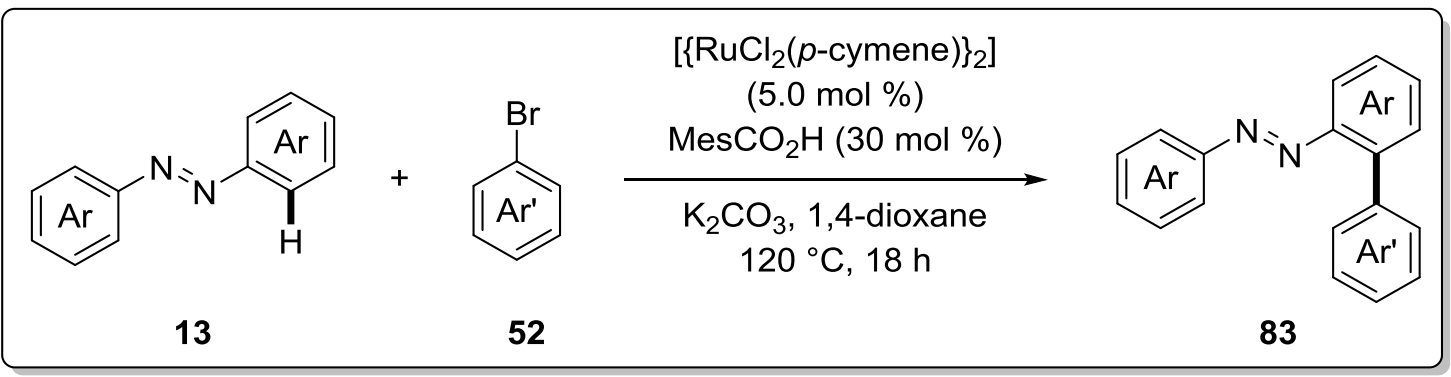

entry

13

83

yield / \%

1<smiles>c1ccc(/N=N/c2ccccc2)cc1</smiles>

2<smiles>c1ccc(/N=N/c2ccccc2)cc1</smiles>

13b<smiles>COC(=O)c1ccc(-c2ccccc2N=Nc2ccccc2)cc1</smiles>

13b<smiles>c1ccc(/N=N/c2ccccc2-c2ccccc2)cc1</smiles>

83ba 59

83bb 
3<smiles>Cc1ccccc1/N=N/c1c(C)cccc1C</smiles><smiles>COC(=O)c1ccc(-c2cccc(C)c2/N=N/c2ccccc2C)cc1</smiles><smiles>Cc1ccccc1/N=N/c1ccccc1C</smiles>

5<smiles>Cc1ccc(/N=N/c2ccc(C)cc2)cc1</smiles>

6<smiles>Cc1cccc(/N=N/c2cccc(C)c2)c1</smiles>

7<smiles>CCc1cccc(N=Nc2cccc(CC)c2)c1</smiles>

8<smiles>CCCc1cccc(N=Nc2cccc(C(C)C)c2)c1</smiles>

13a<smiles>CCOc1ccc(-c2ccc(C)cc2/N=N/c2cccc(C)c2)cc1</smiles>

$13 e$<smiles>CCc1cccc(/N=N/c2cc(CC)ccc2-c2ccc(C(C)=O)cc2)c1</smiles>

13f<smiles>CCCCc1ccc(-c2ccc(C(=O)OC)cc2)c(N=Nc2cccc(C(C)C)c2)c1</smiles>

$13 c$

13c

13d<smiles>CC(=O)c1ccc(-c2cccc(C)c2/N=N/c2ccccc2C)cc1</smiles>

83ca

60

83cc

83da

65

83fa $\quad 80,75^{[\mathrm{b}]}$

83ea $83,79^{[b]}$ 
9<smiles>COc1cccc(N=Nc2cccc(OC)c2)c1</smiles>

10<smiles>COc1cccc(N=Nc2cccc(OC)c2)c1</smiles>

11<smiles>Cc1cccc(N=Nc2cccc(C)c2)c1</smiles>

12<smiles>Cc1cccc(N=Nc2cccc(C)c2)c1</smiles>

13<smiles>Cc1cccc(N=Nc2cccc(C)c2)c1</smiles>

$13 g$<smiles>COc1cccc(/N=N/c2cc(OC)ccc2-c2ccc(C(C)=O)cc2)c1</smiles>

83ga 74

$13 g$<smiles>COc1cccc(N=Nc2cc(OC)ccc2-c2ccc(C(C)=O)cc2)c1</smiles>

83gc 53

83ad 58

13a<smiles>Cc1cccc(N=Nc2cc(C)ccc2-c2ccc(Cl)cc2)c1</smiles>

83ae 56

13a<smiles>Cc1cccc(N=Nc2cc(C)ccc2-c2ccc(N(C)C)cc2)c1</smiles>

83af 67 
14<smiles>Cc1cccc(/N=N/c2cccc(C)c2)c1</smiles>

15<smiles>Cc1cccc(/N=N/c2cccc(C)c2)c1</smiles>

16<smiles>Cc1cccc(/N=N/c2cccc(C)c2)c1</smiles>

17<smiles>Cc1cccc(/N=N/c2cccc(C)c2)c1</smiles>

$13 \mathbf{a}$<smiles>Cc1cccc(/N=N/c2cccc(C)c2)c1</smiles>

$13 \mathbf{a}$

$13 \mathbf{a}$

13a

13a<smiles>Cc1cccc(/N=N/c2cc(C)ccc2-c2ccc(C=O)cc2)c1</smiles>

83ag 51<smiles>CC(=O)c1ccc(-c2ccc(C)cc2/N=N/c2cccc(C)c2)cc1</smiles>

83ac 65<smiles>CCOC(=O)c1ccc(-c2ccc(C)cc2/N=N/c2cccc(C)c2)cc1</smiles>

83ah 63<smiles>Cc1cccc(/N=N/c2cc(C)ccc2-c2ccc(C#N)cc2)c1</smiles>

83ai 64<smiles>Cc1cccc(/N=N/c2cc(C)ccc2-c2ccc([N+](=O)[O-])cc2)c1</smiles> 
19<smiles>Cc1cccc(/N=N/c2cccc(C)c2)c1</smiles>

20<smiles>Cc1cccc(N=Nc2cccc(C)c2)c1</smiles>

21<smiles>Cc1cccc(N=Nc2cccc(C)c2)c1</smiles>

22<smiles>Fc1ccccc1/N=N/c1ccccc1F</smiles>

23<smiles>Fc1cccc(N=Nc2cccc(F)c2)c1</smiles>

13i

13h<smiles>COC(=O)c1ccc(-c2cccc(F)c2N=Nc2ccccc2F)cc1</smiles><smiles>COC(=O)c1ccc(-c2ccc(F)cc2N=Nc2cccc(F)c2)cc1</smiles>

13j<smiles>COC(=O)c1ccc(-c2ccc(C(F)(F)F)cc2N=Nc2cccc(C(F)(F)F)c2)cc1</smiles>

24<smiles>FC(F)(F)c1cccc(N=Nc2cccc(C(F)(F)F)c2)c1</smiles>

$13 a$<smiles>CC/C(=C/N=Nc1cccc(C)c1)c1ccc(Cl)c(Cl)c1</smiles>

83ak 56

83al 86

83am 63

\section{3ha}

83ia

83ja<smiles>CCC</smiles> 
25<smiles>COC(=O)c1cccc(/N=N/c2cccc(C(C)=O)c2)c1</smiles>

26<smiles>COC(=O)c1cccc(/N=N/c2cccc(C(C)=O)c2)c1</smiles>

$13 \mathbf{k}$<smiles>COC(=O)c1ccc(-c2ccc(C(C)=O)cc2/N=N/c2cccc(C(C)=O)c2)cc1</smiles>

83ka

$13 \mathbf{k}$<smiles>COC(=O)c1cccc(/N=N/c2cc(C(C)=O)ccc2-c2ccc(Cl)c(Cl)c2)c1</smiles>

$83 \mathrm{~km}$

${ }^{[a]}$ General reaction conditions: $13(1.0 \mathrm{mmol}), \mathbf{5 2}(0.50 \mathrm{mmol}),\left[\left\{\mathrm{RuCl}_{2}(p \text {-cymene })\right\}_{2}\right](5.0 \mathrm{~mol} \%), \mathrm{MesCO}_{2} \mathrm{H}$ $(30 \mathrm{~mol} \%)$, base $(1.0 \mathrm{mmol}), 1,4$-dioxane $(2.0 \mathrm{~mL}), 120{ }^{\circ} \mathrm{C}, 18 \mathrm{~h}$; isolated yields. ${ }^{[\mathrm{b}]} \mathrm{KOAc}(30 \mathrm{~mol} \%)$.

In an atom- and step-economical manner, various heteroaryl electrophiles $31 \mathrm{n}$ and $\mathbf{5 2 n}-\mathbf{5 2 s}$ delivered the desired $\mathrm{C}-\mathrm{H}$ arylated products $\mathbf{8 3}$ in moderate to high yields (Table 13). Based on the relevance of heteroarenes as valuable building blocks in numerous bioactive compounds, these findings highlight the synthetic utility of the method. The direct arylation with the electron-deficient pyridinyl 52r and pyrimidinyl 52s bromide was less effective (entries 5 and 6).

Table 13: Scope with respect to heteroaromatic halides $63{ }^{[\mathrm{a}]}$

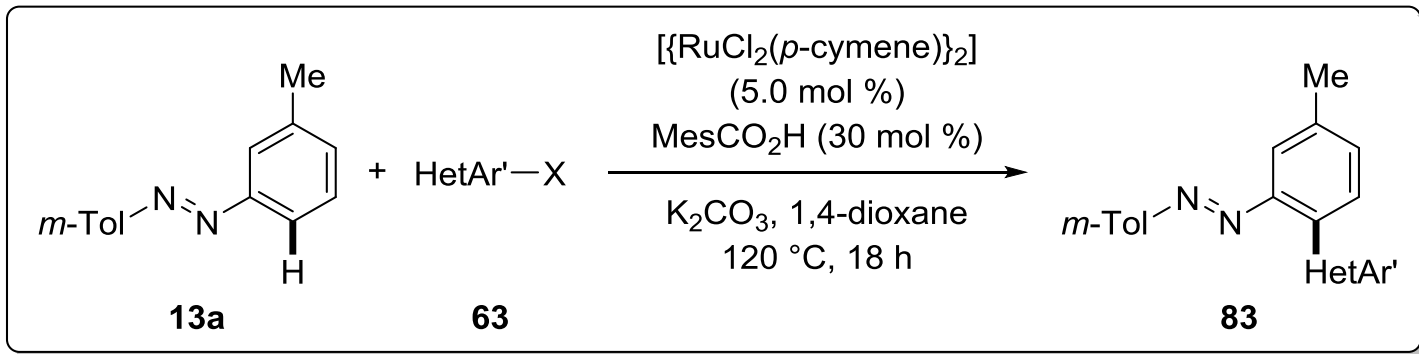

\begin{tabular}{llllll}
\hline entry & HetAr'-X & & yield / \% \\
\hline 1 & 31n & 83an &
\end{tabular}


2<smiles>Brc1cccs1</smiles>

52n<smiles>Brc1ccsc1</smiles>

4<smiles>Brc1ccc2[nH]ccc2c1</smiles>

52p

520<smiles>Cc1ccc(-c2cccs2)c(N=N[Ge][Te])c1</smiles>

83an

62

83ao

51<smiles>Cc1ccc(-c2ccsc2)c(N=N[Ge]=[Te])c1</smiles>

83ap

54

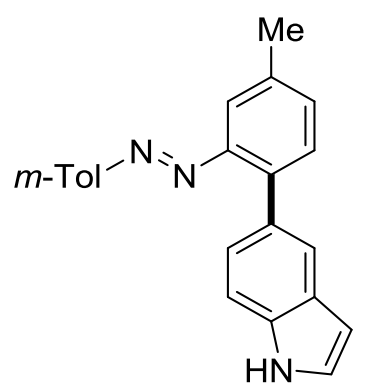

83aq

74

$52 q$<smiles></smiles>

83ar

31

$52 r$<smiles>Cc1ccc(-c2cccnc2)c(N=N[Ge][Te])c1</smiles><smiles>Cc1ccc(-c2cncnc2)c(N=N[Ge][Te])c1</smiles>

83as

28

${ }^{\text {[a] }}$ General reaction conditions: 13a $(1.0 \mathrm{mmol}), \mathbf{6 3}(0.50 \mathrm{mmol}),\left[\left\{\mathrm{RuCl}_{2}(p \text {-cymene })\right\}_{2}\right](5.0 \mathrm{~mol} \%), \mathrm{MesCO}_{2} \mathrm{H}$ (30 mol \%), base $(1.0 \mathrm{mmol}), 1,4$-dioxane $(2.0 \mathrm{~mL}), 120^{\circ} \mathrm{C}, 18 \mathrm{~h}$; isolated yields. 
In addition, the unsymmetrical azoarene 13I reacted smoothly under otherwise identical reaction conditions, providing 83la in an excellent regioselectivity and yield (Scheme 28).

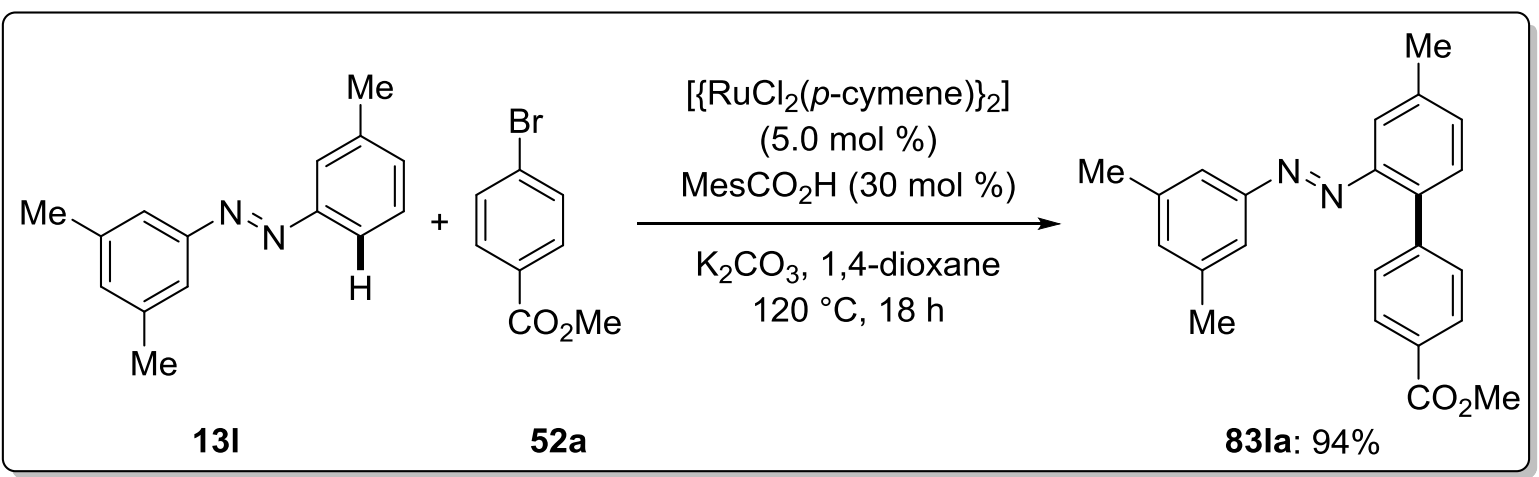

Scheme 28: C-H Functionalization of unsymmetrical azoarene 131.

The working mode of the well-defined robust ruthenium(II) biscarboxylate catalyst $\mathbf{8 4}^{[146]}$ was also tested and supplied improved results compared to the in situ formed system (Scheme 29).

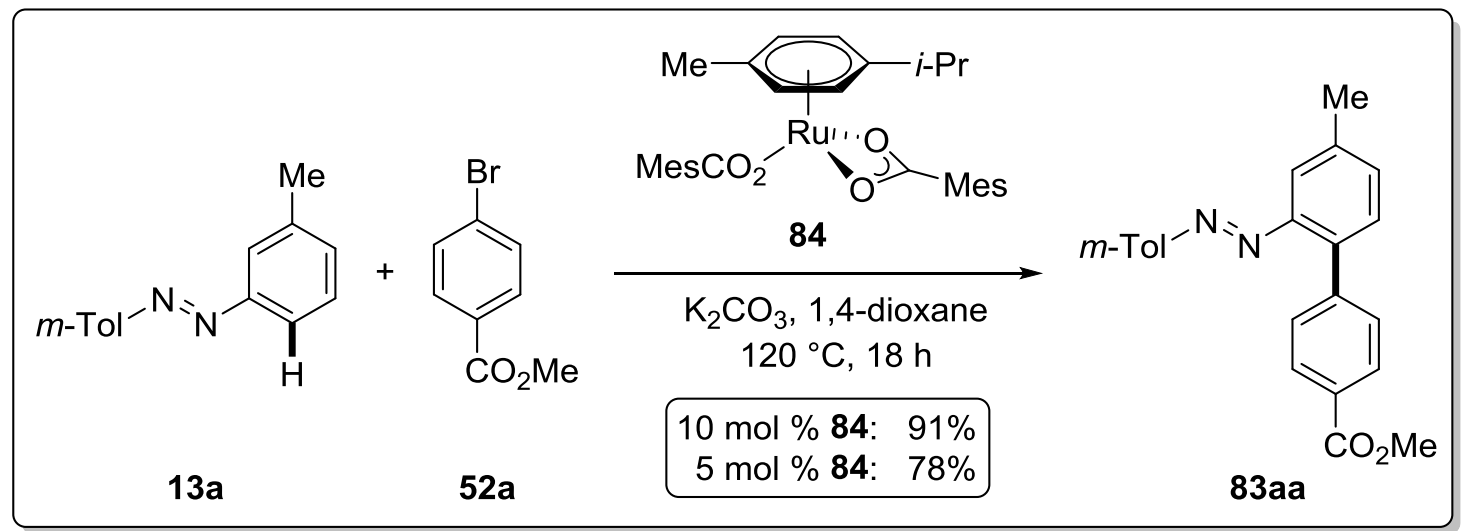

Scheme 29: Ruthenium(II) biscarboxylate catalyst 84 for the $\mathrm{C}-\mathrm{H}$ arylation. 


\subsubsection{One-pot synthesis for expedient access to ortho-arylated anilines}

A straightforward method to obtain ortho-arylated anilines $\mathbf{3 4}$ was achieved in a sustainable and efficient one pot synthesis via $\mathrm{C}-\mathrm{H}$ funtionalization as the key step (Tabel 14). A practical strategy starting from azoarenes $\mathbf{1 3}$ by applying $\mathrm{C}-\mathrm{H}$ arylation and following reduction of the azo group ${ }^{[147-151]}$ provided the corresponding products 34 .

Table 14: Practical one-pot synthesis to ortho-arylated anilines $34 .^{[\mathrm{a}]}$

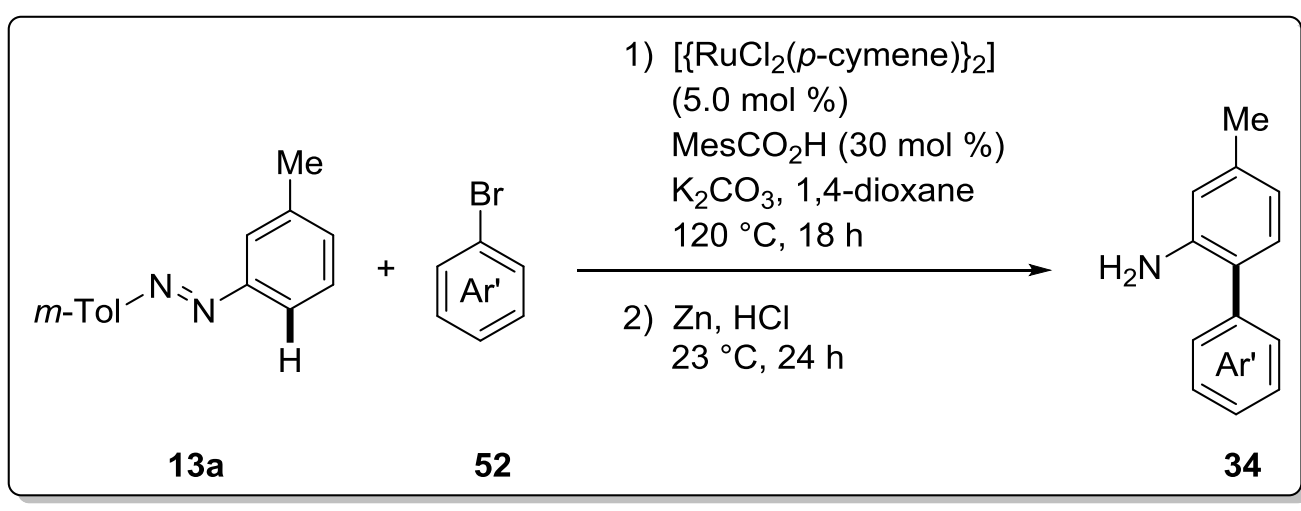

entry


4<smiles>COc1cc(Br)cc(OC)c1OC</smiles>

5<smiles>Clc1ccc(Br)cc1Cl</smiles>

521<smiles>COc1cc(-c2ccc(C)cc2N)cc(OC)c1OC</smiles>

34al 84

$52 \mathrm{~m}$ 34am

${ }^{[a]}$ General reaction conditions: 1) 13a $(1.0 \mathrm{mmol}), 52(0.50 \mathrm{mmol}),\left[\left\{\mathrm{RuCl}_{2}(p \text {-cymene })\right\}_{2}\right] \quad(5.0 \mathrm{~mol} \%)$, $\mathrm{MesCO}_{2} \mathrm{H}(30 \mathrm{~mol} \%)$, base (1.0 mmol), 1,4-dioxane (2.0 mL), $\left.120^{\circ} \mathrm{C}, 18 \mathrm{~h} ; 2\right) \mathrm{Zn}(2.5 \mathrm{~mol} \%), \mathrm{HCl}(0.4 \mathrm{~mL})$, $23{ }^{\circ} \mathrm{C}, 24 \mathrm{~h}$; isolated yields. 


\subsubsection{Mechanistic studies}

\subsubsection{H/D Exchange experiments}

To obtain insights into the mechanism of the ruthenium(II)-catalyzed $\mathrm{C}-\mathrm{H}$ activation of azoarenes, H/D exchange experiments with $\mathrm{D}_{2} \mathrm{O}$ as the co-solvent were conducted. In the absence of the aryl bromide, a significant H/D scrambling solely in the ortho-position of the recovered azoarene $\left[\mathrm{D}_{n}\right]-\mathbf{- 1 3 b}$ was observed (Scheme 30a). For the standard reaction conditions, a considerable amount of deuterium incorporation in the ortho-position of the reisolated starting material $\left[\mathrm{D}_{n}\right]-\mathbf{1 3 d}$ and the product $\left[\mathrm{D}_{n}\right]-\mathbf{8 3 d a}$ was detected (Scheme $30 \mathrm{~b}$ ). These results revealed the reversible nature of the $\mathrm{C}-\mathrm{H}$ ruthenation step. Furthermore, it demonstrated the potential of the ruthenium catalyst towards the remarkably selective cleavage of $\mathrm{C}-\mathrm{H}$ bonds. ${ }^{[146]}$

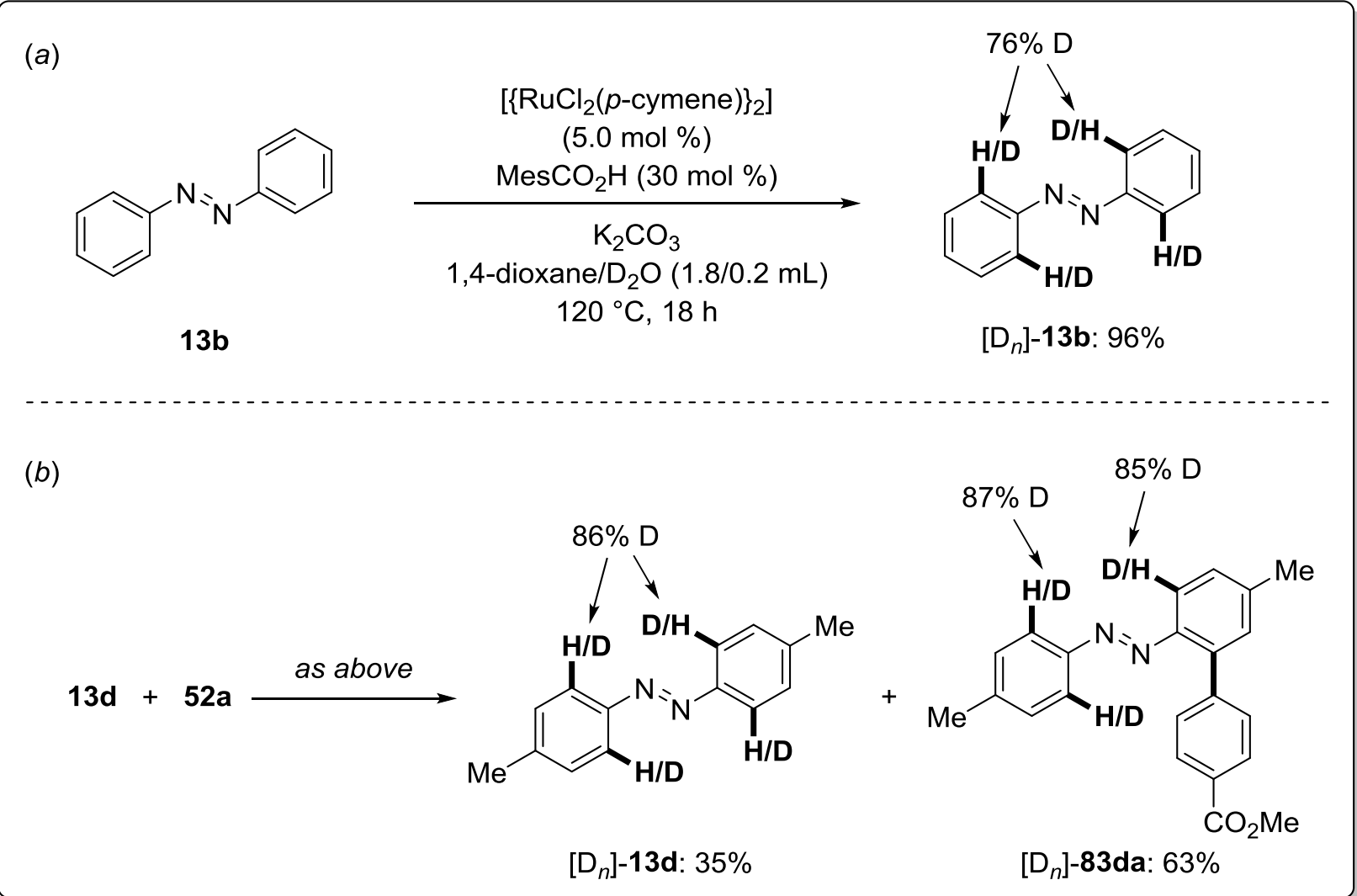

Scheme 30: H/D Scrambling studies in the presence of $\mathrm{D}_{2} \mathrm{O}$. 


\subsubsection{Experiments with radical scavengers}

The catalytic performance of the ruthenium(II)-carboxylate complex was considerably inhibited in the presence of typical radical scavengers, suggesting that a SET-type $\mathrm{C}-\mathrm{X}$ cleavage process may be operative here (Table 15$).{ }^{[131]}$

Table 15: Influence of radical scavengers in the $\mathrm{C}-\mathrm{H}$ arylation process. ${ }^{[\mathrm{a}]}$

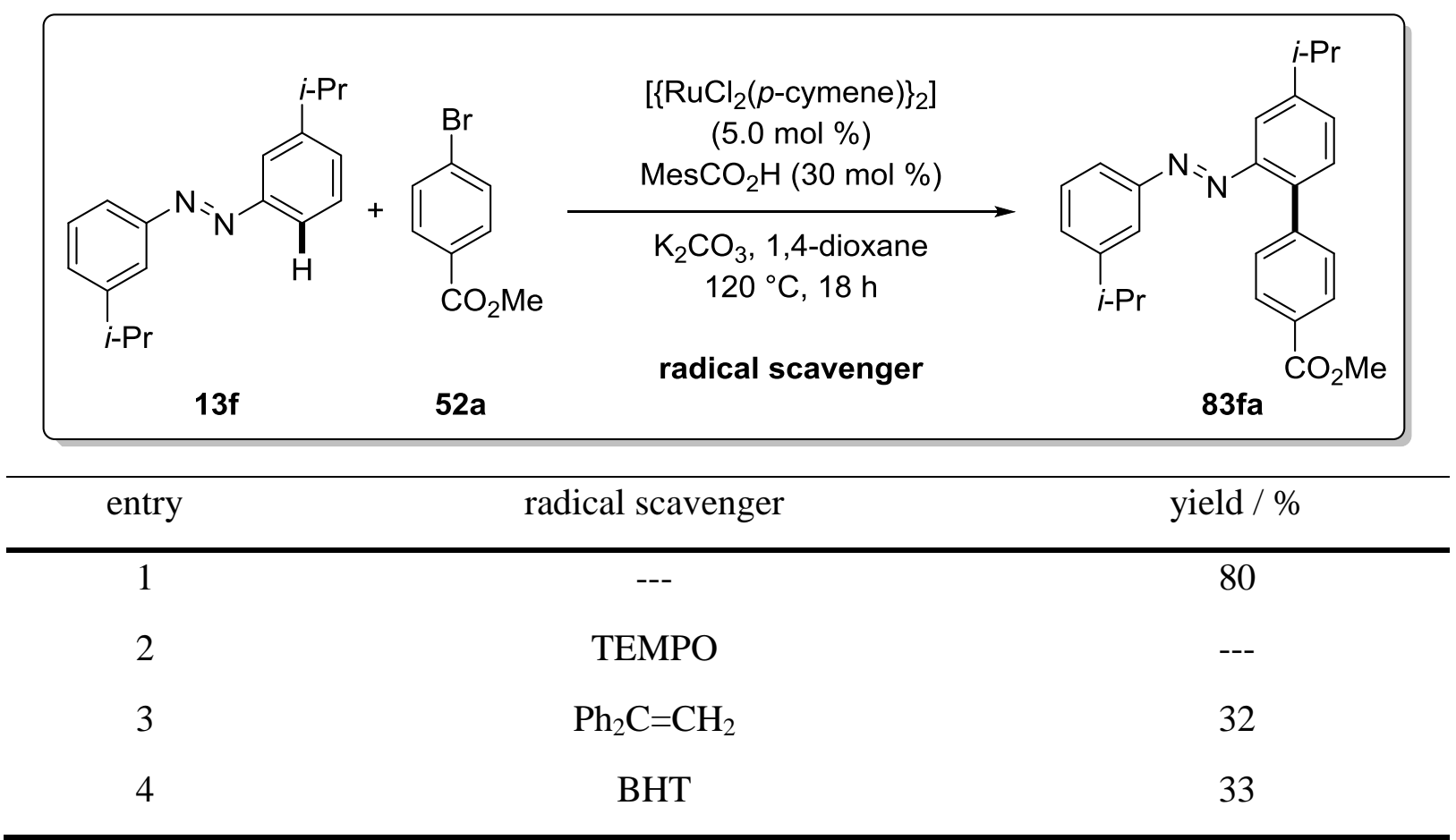

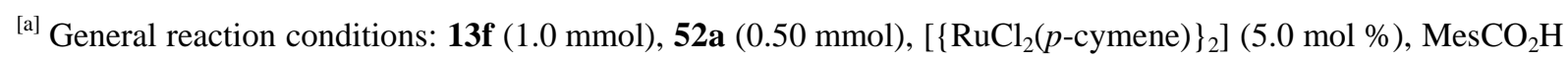
$(30 \mathrm{~mol} \%), \mathrm{K}_{2} \mathrm{CO}_{3}(1.0 \mathrm{mmol}), 1,4$-dioxane $(2.0 \mathrm{~mL})$, radical scavenger (1.0 equiv), $120{ }^{\circ} \mathrm{C}, 18 \mathrm{~h}$; isolated yields. TEMPO = 2,2,6,6-tetramethylpiperidine 1-oxyl, BHT = butylated hydroxytoluene. 


\subsubsection{Hammett plot analysis}

The investigation of the initial rate for the ruthenium(II)-catalyzed carboxylate-assisted $\mathrm{C}-\mathrm{H}$ arylations with diversely para-substituted aryl bromides $\mathbf{5 2}$ displayed a rate acceleration preferably influenced through electron-donating groups (Figure 3).
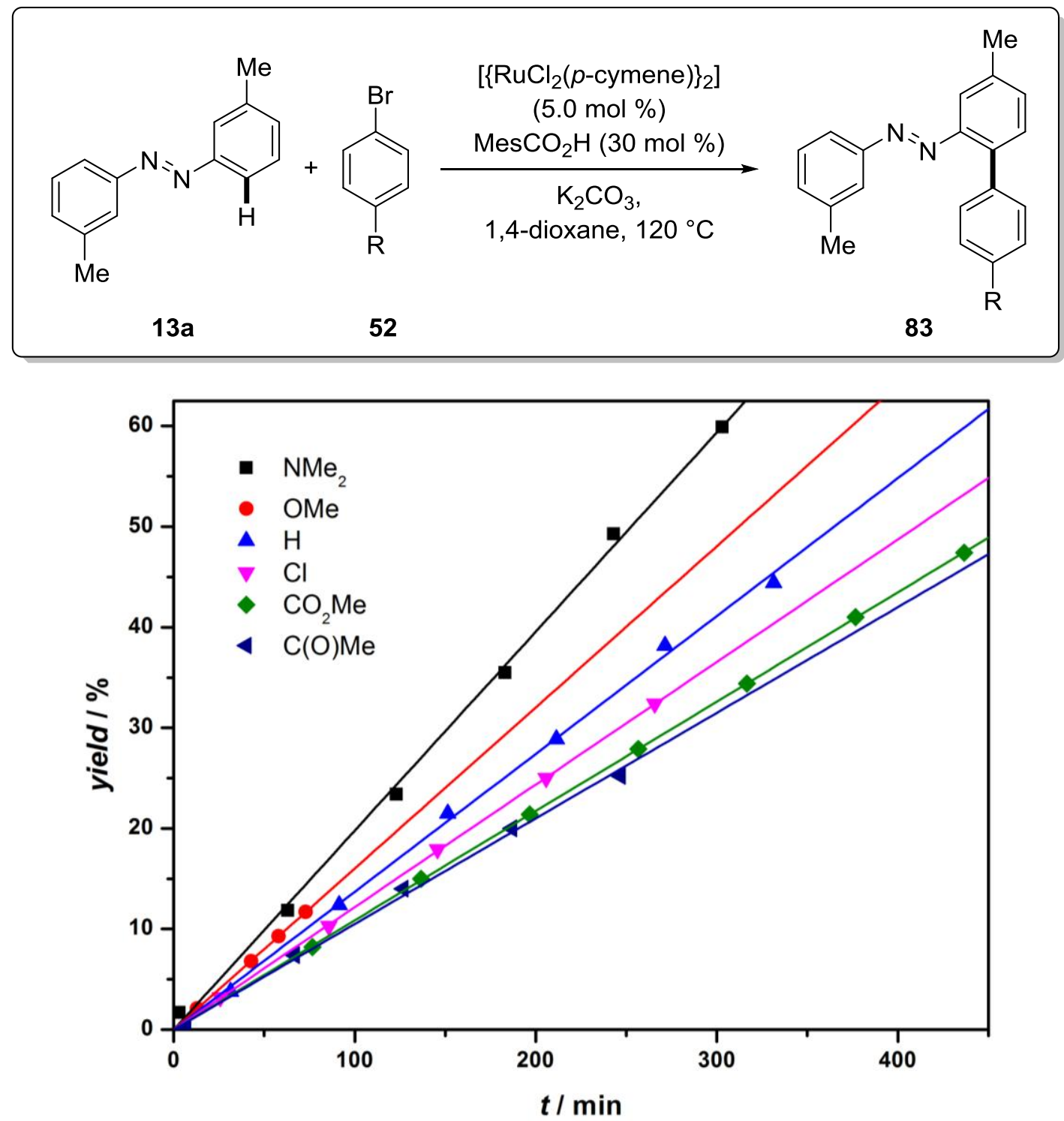

Figure 3: Comparison of the initial rates exerted by the different aryl bromides $\mathbf{5 2}$.

Afterwards, a Hammett plot was constructed from the correlation between the initial rate and the corresponding $\sigma_{\mathrm{p}}$ value (Figure 4 ). The plot resulted in a linear fit with a negative slope of $\rho=-0.21 \pm 0.01$, suggesting the $\mathrm{C}-\mathrm{H}$ activation promoted by electron-donating substituents. In contrast to the previous findings, this result implies a $\mathrm{C}-\mathrm{X}$ cleavage as rate-determining 
step is less likely for the direct arylations. Additionally, the value of $\rho=-0.21 \pm 0.01$ is rather small, and values of this magnitude are more difficult to accurately interpret. ${ }^{[152-156]}$

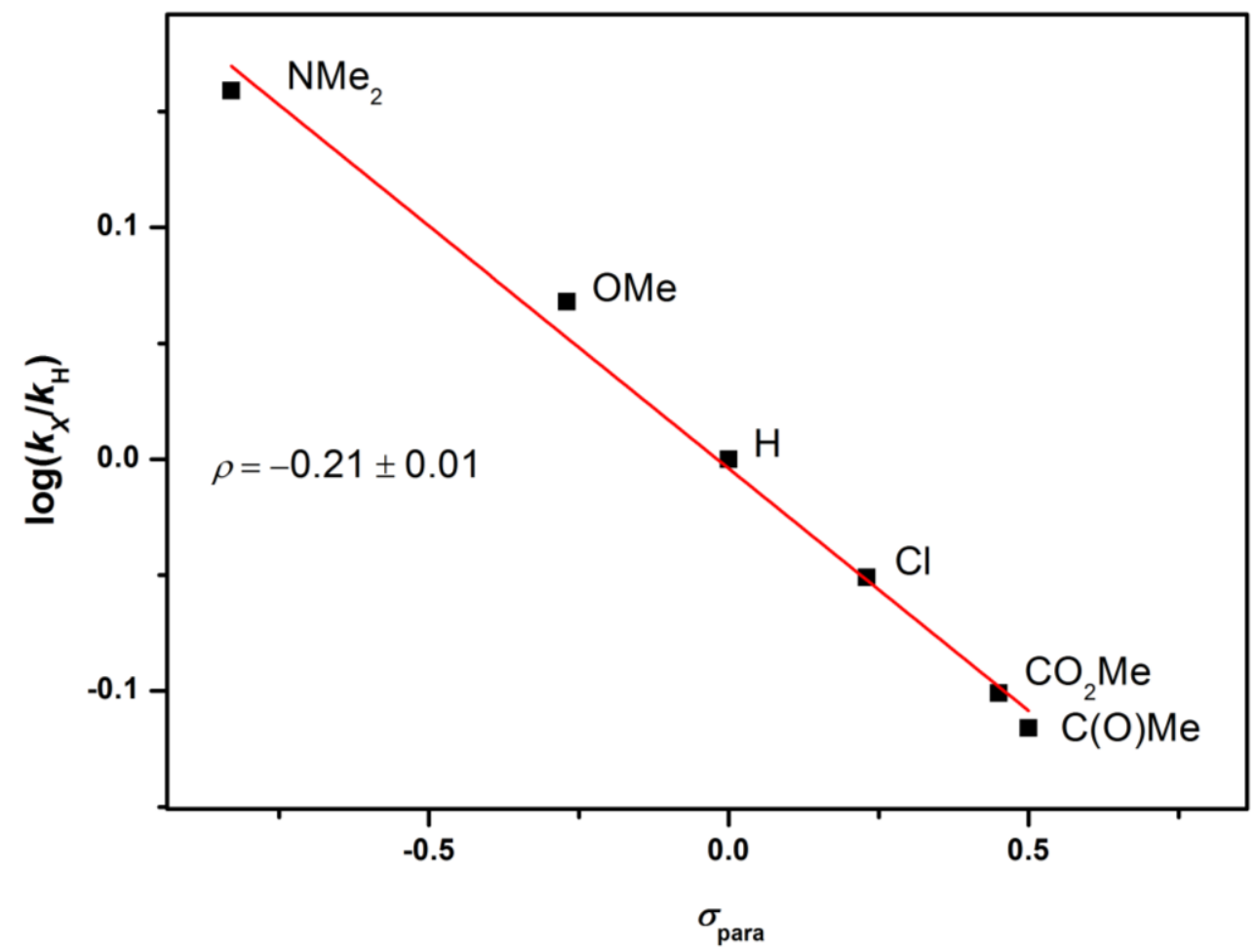

Figure 4: Hammett plot correlation of azoarene 13a with para-substituted aryl bromides $\mathbf{5 2}$.

\subsubsection{Proposed catalytic cycle}

Based on the experimental studies, a detailed catalytic cycle for the ruthenium(II)-catalyzed ortho- $\mathrm{C}-\mathrm{H}$ arylation by carboxylate assistance is delineated in Scheme 31. In the initial stage, the active ruthenium(II)-carboxylate complex $\mathbf{8 5}$ is formed in situ, followed by coordination of the azoarene 13 to deliver complex 86. Afterwards, a reversible isohypsic ortho-C-H bond ruthenation is promoted via a six-membered inner-sphere concerted ruthenation-deprotonation transition state $\mathbf{8 7}$, providing the five-membered ruthena(II)cycle $\mathbf{8 8}$ as a key intermediate. ${ }^{[7,107,146]}$ Here, it is proposed that the carboxylic acid facilitates the $\mathrm{C}-\mathrm{H}$ bond cleavage, which serves as a catalytic proton shuttle from the transition state of the CMD process to the insoluble carbonate base. ${ }^{[146]}$ Thereafter, formal oxidative addition of the aryl electrophile 63 by a SET-type via homolytic $\mathrm{C}-\mathrm{X}$ bond cleavage affords the reactive ruthenium(IV) species $\mathbf{9 0}$. Finally, reductive elimination releases the desired biaryl product $\mathbf{8 3}$ and regenerates the active ruthenium(II) catalyst $\mathbf{8 5}$ required for another turnover of the catalytic cycle. ${ }^{[15,117]}$ 


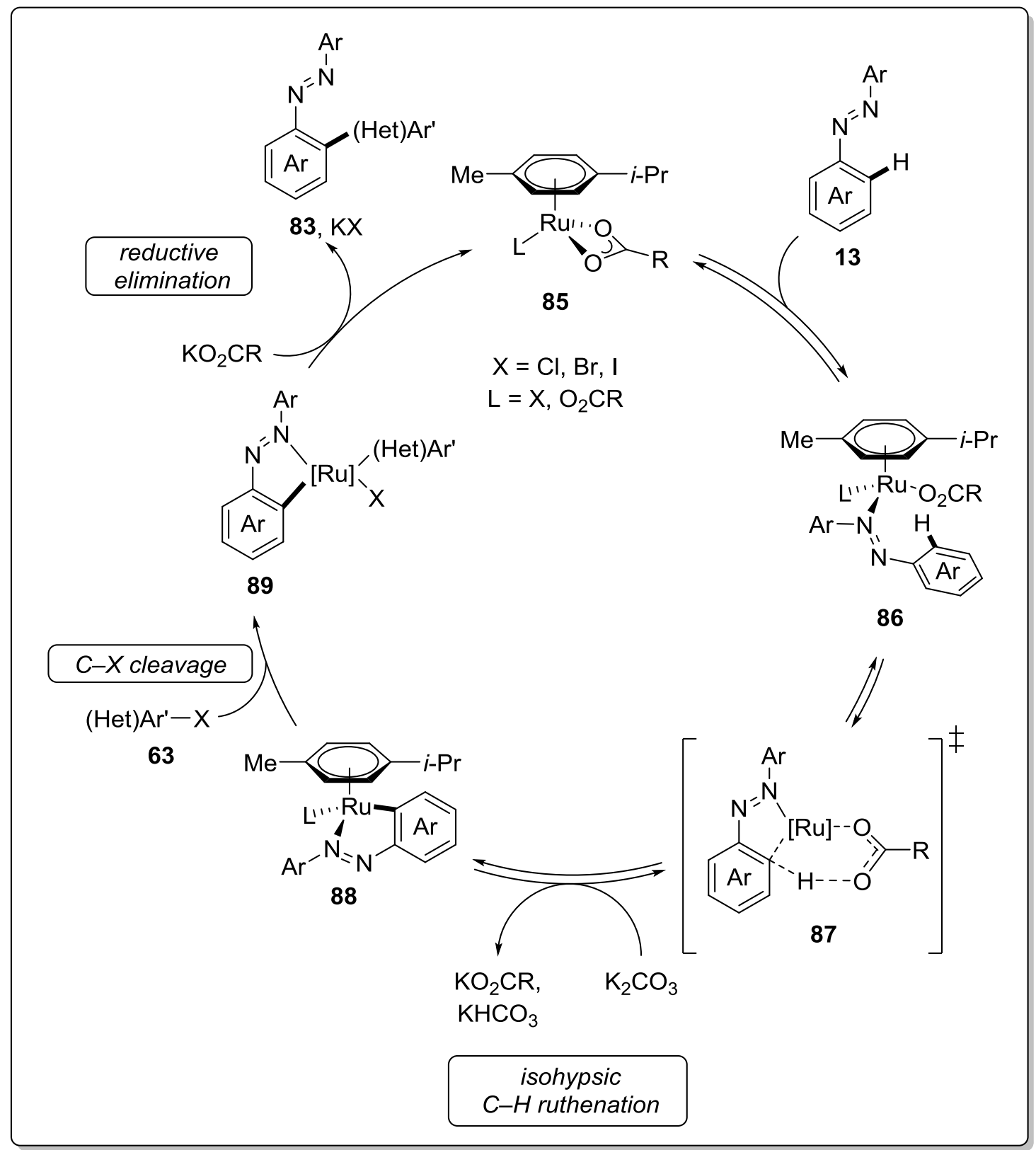

Scheme 31: Proposed catalytic cycle for the ruthenium(II)-catalyzed C-H arylation. 


\subsection{Ruthenium(II)-catalyzed $\mathrm{C}-\mathrm{H}$ arylation of 5-aryl-1H-tetrazoles}

\subsubsection{Optimization of $\mathrm{C}-\mathrm{H}$ arylation of $1 \mathrm{H}$-tetrazole 68a with aryl chloride 59a}

At the outset, various reaction conditions were evaluated for the ruthenium-catalyzed $\mathrm{C}-\mathrm{H}$ arylation of 1-benzyl-5-phenyl-1H-tetrazole (68a) using inexpensive aryl chloride 59a in a high chemo- and positional-selectivity (Tables 16-20). Preliminary studies of the co-catalyst identified mono- $N$-protected amino acids (MPAAs) ${ }^{[157-159]}$ and carboxylic acids ${ }^{[7,15]}$ as key pre-ligands in this respect (Table 16). The tetrazole-directed arylation was less effective in the absence of additives (entry 1). It is noteworthy that further co-cataltytic additives, such as secondary phosphine oxides (SPOs), ${ }^{[7,103,104]}$ the phosphoric acid diester $(\mathrm{PhO}){ }_{2} \mathrm{P}(\mathrm{O}) \mathrm{OH}^{[7,117]}$ or $\mathrm{KOAc}^{[40,118]}$ provided the $\mathrm{C}-\mathrm{H}$ arylated product 69aa in lower yields (entries 2-5). In light of these findings, an extensive screening of several carboxylic acids and MPAAs was conducted (entries 6-28). The use of adamantyl carboxylic acid and pivalic acid gave inferior results compared to mesityl carboxylic acid (entries 6-8). A set of representative MPAAs was tested and Piv-Val-OH emerged as the most effective co-catalyst, whereas dipeptides furnished the desired product 69aa in unsatisfactory yields (entries 23-25). The optimal preligand loading of Piv-Val-OH was $30 \mathrm{~mol} \%$ (entries 11 and 26-28).

Table 16: Effect of co-catalyst. ${ }^{[\mathrm{a}]}$

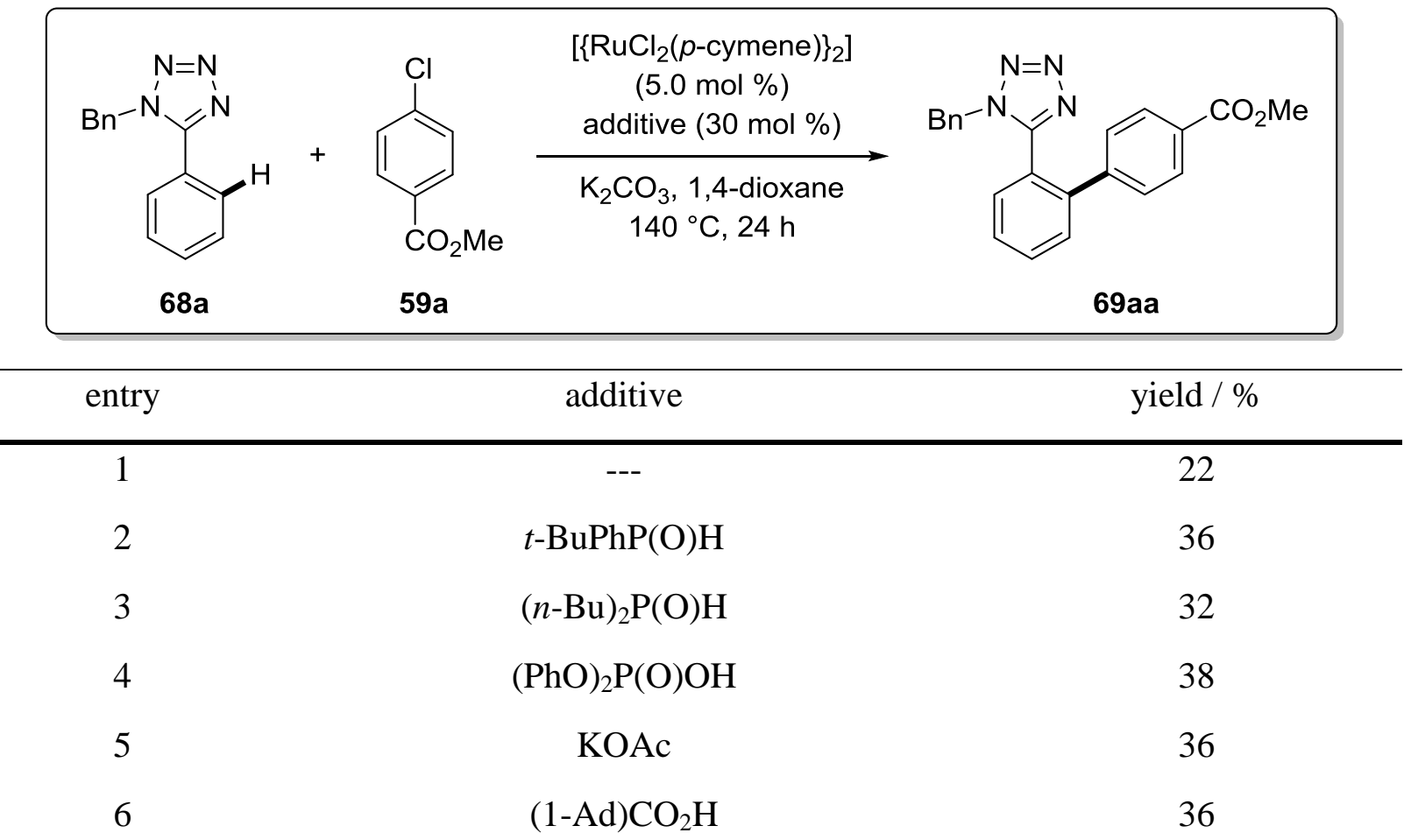


7

8

9

10

11

12

13

14

15

16

17

18

19

20

21

22

23

24

25

26

27

28
$t-\mathrm{BuCO}_{2} \mathrm{H}$

39

$\mathrm{MesCO}_{2} \mathrm{H}$

47

Piv-Ala-OH 39

Phth-Ala-OH 35

Piv-Val-OH $\quad 58$

Piv-Leu-OH 42

Ac-Ile-OH 46

Piv-Ile-OH 51

Ada-Ile-OH 48

$\begin{array}{ll}\mathrm{MeO}_{2} \mathrm{C} \text {-Ile-OH } & 37\end{array}$

Boc-Ile-OH 41

Piv-Phe-OH 44

Phth-Phe-OH 41

$\begin{array}{ll}\text { Piv-Met-OH } & 16\end{array}$

$\begin{array}{ll}\text { Piv-Asp-OH } & 50\end{array}$

$\begin{array}{ll}\text { Piv-Asn-OH } & 17\end{array}$

Phth-Ala-Trp-OH 29

Boc-Val-Gly-OH 45

Boc-Ile-Phe-OH 32

Piv-Val-OH $44^{[b]}$

Piv-Val-OH $52^{[\mathrm{c}]}$

Piv-Val-OH $54^{[\mathrm{d}]}$

${ }^{[a]}$ General reaction conditions: 68a $(0.30 \mathrm{mmol}), \mathbf{5 9 a}(0.90 \mathrm{mmol}),\left[\left\{\mathrm{RuCl}_{2}(p \text {-cymene })\right\}_{2}\right](5.0 \mathrm{~mol} \%)$, additive (30 mol \%), $\mathrm{K}_{2} \mathrm{CO}_{3} \quad(0.90 \mathrm{mmol}), \quad 1,4$-dioxane $(2.0 \mathrm{~mL}), \quad 140{ }^{\circ} \mathrm{C}, 24 \mathrm{~h}$; isolated yields. ${ }^{[b]}$ Piv-Val-OH (10 mol \%). ${ }^{[\mathrm{cc}]} \mathrm{Piv}-\mathrm{Val}-\mathrm{OH}(20 \mathrm{~mol} \%) .{ }^{[\mathrm{d}]} \mathrm{Piv}-\mathrm{Val}-\mathrm{OH}(40 \mathrm{~mol} \%)$. 
The ruthenium(II)-catalyzed chelation-assisted $\mathrm{C}-\mathrm{H}$ activation revealed a significant temperature- and concentration-dependence under otherwise identical reaction conditions (Table 17).

Table 17: Effect of concentration. ${ }^{[a]}$

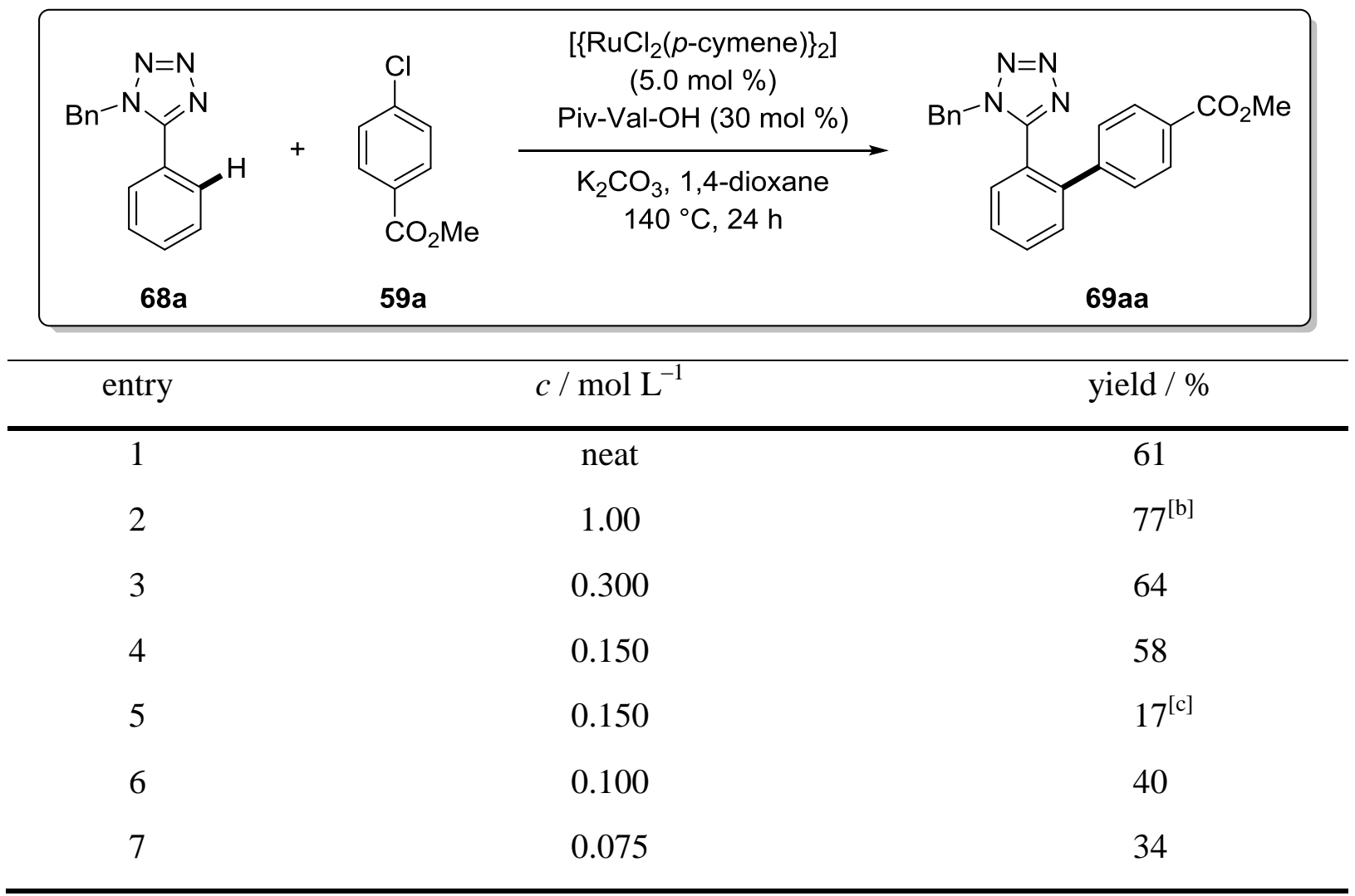

${ }^{[a]}$ General reaction conditions: 68a $(0.30 \mathrm{mmol}), \quad 59 a(0.90 \mathrm{mmol}), \quad\left[\left\{\mathrm{RuCl}_{2}(p-\text { cymene })\right\}_{2}\right] \quad(5.0 \mathrm{~mol} \%)$, Piv-Val-OH (30 mol \%), $\mathrm{K}_{2} \mathrm{CO}_{3}(0.90 \mathrm{mmol}), 1,4$-dioxane $\left(\mathrm{mol} \mathrm{L}^{-1}\right), 140{ }^{\circ} \mathrm{C}, 24 \mathrm{~h}$; isolated yields. ${ }^{[\mathrm{b}]} 10 \%$ of diarylated product 69aa' was isolated. ${ }^{[\mathrm{c}]} 120{ }^{\circ} \mathrm{C}$.

Further optimization studies under otherwise identical reaction conditions disclosed $\mathrm{K}_{2} \mathrm{CO}_{3}$ as stoichiometric and insoluble base of choice, which improved the activity of the ruthenium(II) catalyst in conjunction with the soluble pre-ligand Piv-Val-OH (Table 18). In this context, it is worth mentioning that Fagnou revealed a considerable influence of the catalytic efficiency exerted by the solubility of bases in palladium catalysis. ${ }^{[160]}$ This observation was confirmed through the previously discussed ruthenium(II)-catalyzed $\mathrm{C}-\mathrm{H}$ arylation of azoarenes (Table 11). 
Table 18: Effect of bases. ${ }^{[a]}$

base
68a

${ }^{[a]}$ General reaction conditions: 68a $(0.30 \mathrm{mmol}), \quad 59 a \quad(0.90 \mathrm{mmol}), \quad\left[\left\{\mathrm{RuCl}_{2}(p \text {-cymene })\right\}_{2}\right] \quad(5.0 \mathrm{~mol} \%)$, Piv-Val-OH $(30 \mathrm{~mol} \%)$, base $(0.90 \mathrm{mmol}), 1,4$-dioxane $(0.3 \mathrm{~mL}), 140{ }^{\circ} \mathrm{C}, 24 \mathrm{~h}$; isolated yields. ${ }^{[\mathrm{b}]} 10 \%$ of diarylated product 69aa' was isolated. ${ }^{[\mathrm{c}]}(0.60 \mathrm{mmol}){ }^{[\mathrm{d}]} 5 \%$ of diarylated product 69aa' was isolated. ${ }^{[\mathrm{e}]} \mathrm{K}_{2} \mathrm{CO}_{3}$ $(0.30 \mathrm{mmol})$.

The direct $\mathrm{C}-\mathrm{H}$ functionalization did not proceed in the absence of the ruthenium catalyst or with the inexpensive $\left[\mathrm{RuCl}_{3}\left(\mathrm{H}_{2} \mathrm{O}\right)_{n}\right]$ (Table 19, entries 1-2). A range of well-defined robust ruthenium(II) complexes ${ }^{[131,146,157]}$ were tested and delivered a comparable catalytic efficiency towards the in situ generated counterparts (entries 3-7).

Table 19: Effect of ruthenium sources. ${ }^{[a]}$

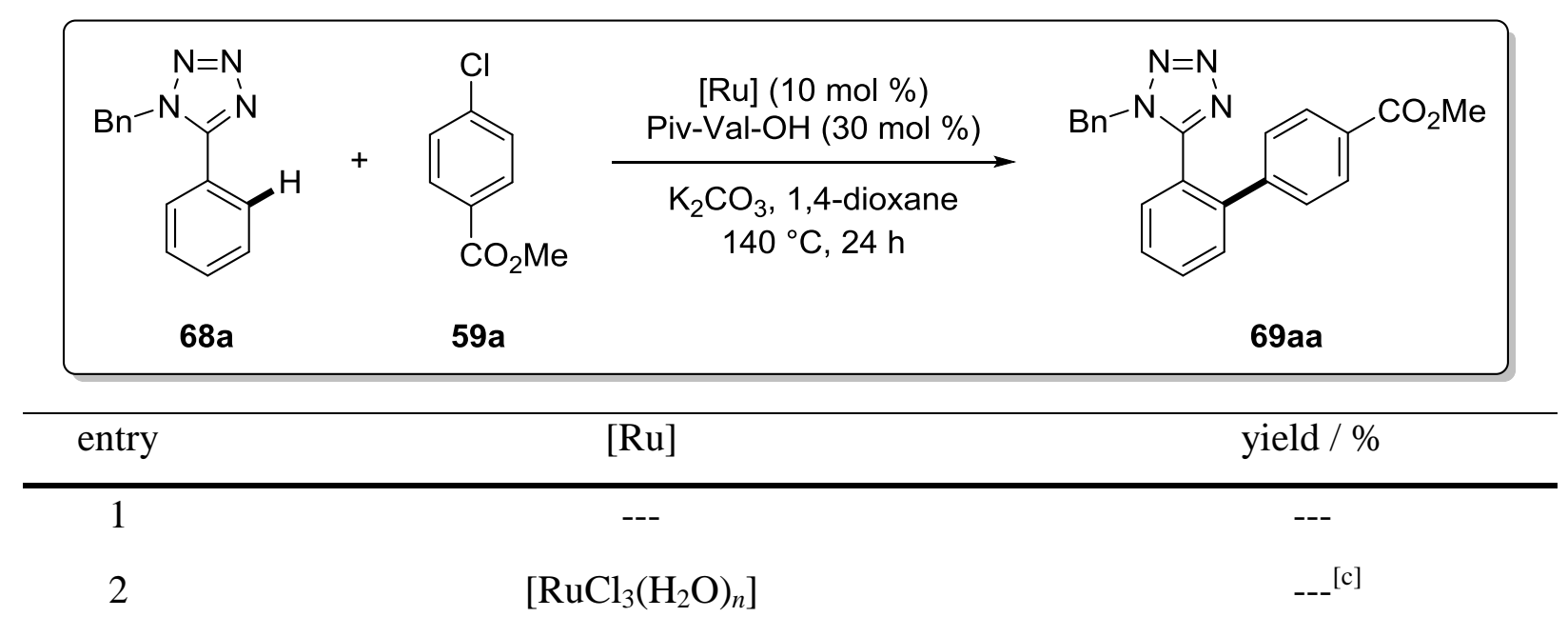




$\begin{array}{ccc}3 & {\left[\left\{\mathrm{RuCl}_{2}(p \text {-cymene })\right\}_{2}\right]} & 77^{[\mathrm{b}]} \\ 4 & {\left[\mathrm{Ru}\left(\mathrm{O}_{2} \mathrm{CMes}\right)_{2}(p \text {-cymene })\right]} & 68^{[\mathrm{d}, \mathrm{e}]} \\ 5 & {\left[\mathrm{RuCl}_{2}(p \text {-cymene })(t \text {-BuPhPHO })\right]} & 58^{[\mathrm{d}]} \\ 6 & {\left[\mathrm{RuCl}_{2}(p \text {-cymene })\left(n-\mathrm{Bu}_{2} \mathrm{PHO}\right)\right]} & 46^{[\mathrm{d}]} \\ 7 & {[\mathrm{RuCl}(\mathrm{O}-\text { Val-Piv })(p \text {-cymene })]} & 79^{[\mathrm{b}, \mathrm{d}]}\end{array}$

${ }^{[a]}$ General reaction conditions: $68 \mathbf{a}(0.30 \mathrm{mmol}), \mathbf{5 9} \mathbf{a}(0.90 \mathrm{mmol})$, $[\mathrm{Ru}](10 \mathrm{~mol} \%)$, Piv-Val-OH $(30 \mathrm{~mol} \%)$, $\mathrm{K}_{2} \mathrm{CO}_{3}(0.90 \mathrm{mmol}), 1,4$-dioxane $(0.3 \mathrm{~mL}), 140{ }^{\circ} \mathrm{C}, 24 \mathrm{~h}$; isolated yields. ${ }^{\text {b] }} 10 \%$ of diarylated product $69 \mathrm{aa}$ ' was isolated. ${ }^{[\mathrm{c}]}[\mathrm{Ru}](5.0 \mathrm{~mol} \%) .{ }^{[\mathrm{d]}}$ In the absence of additive. ${ }^{[\mathrm{e}]} 7 \%$ of diarylated product $69 \mathrm{aa}$ ' was isolated.

Among different solvents 1,4-dioxane proved to be the most suitable one (Table 20). Unfortunately, more sustainable solvents, such as $\mathrm{H}_{2} \mathrm{O}^{[161]}$ and $\gamma$-valerolactone, ${ }^{[162]}$ were unsuccessfully employed (entries 2-3). Other solvents, including toluene, NMP, DMA, DMF or $t-\mathrm{AmOH}$, also resulted in inferior yields (entries 4-8).

Table 20: Effect of solvents. ${ }^{[a]}$

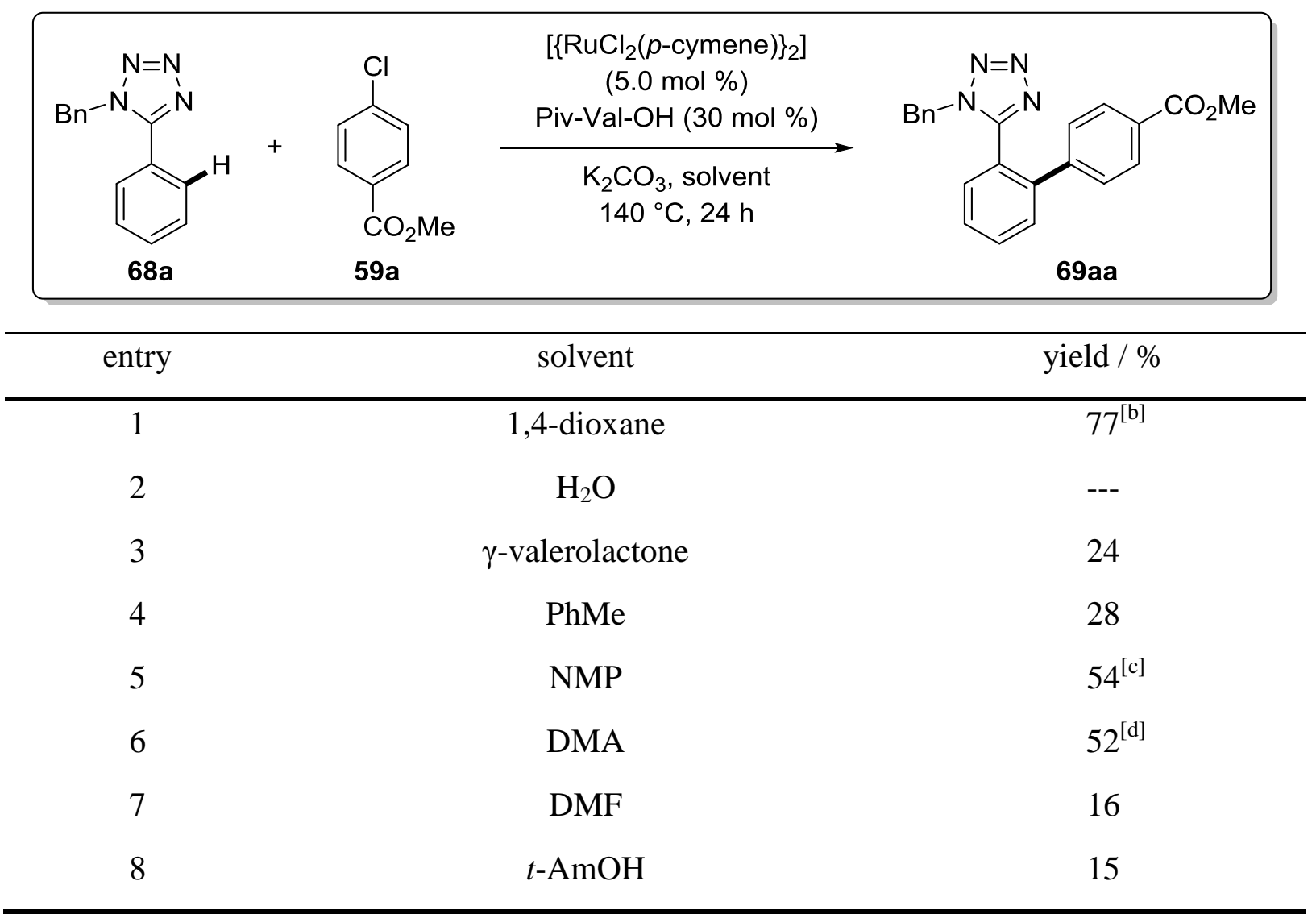

${ }^{[a]}$ General reaction conditions: $68 \mathbf{a}(0.30 \mathrm{mmol}), \quad 59 a \quad(0.90 \mathrm{mmol}), \quad\left[\left\{\mathrm{RuCl}_{2}(p \text {-cymene })\right\}_{2}\right] \quad(5.0 \mathrm{~mol} \%)$, Piv-Val-OH $(30 \mathrm{~mol} \%), \mathrm{K}_{2} \mathrm{CO}_{3}(0.90 \mathrm{mmol})$, solvent $(0.3 \mathrm{~mL}), 140{ }^{\circ} \mathrm{C}, 24 \mathrm{~h}$; isolated yields. ${ }^{[b]} 10 \%$ of diarylated product 69aa' was isolated. ${ }^{[\mathrm{c}]} 32 \%$ of diarylated product 69aa' was isolated. ${ }^{\text {[d] }} 31 \%$ of diarylated product 69aa' was isolated. 


\subsubsection{Scope of $\mathrm{C}-\mathrm{H}$ arylation of 5-aryl-1H-tetrazole with (hetero)aryl electrophiles}

Initially, the scope of 5-aryl- $1 H$-tetrazoles $\mathbf{6 8}$ with cost-effective aryl chloride 59a as electrophilic coupling partner was explored for the novel optimized reaction (Table 21, entries 1-10). Thereby, it was observed that unsubstituted tetrazole 68a was successfully employed contrarily to ortho-substituted $\mathbf{6 8 b}$, which failed (entries 1-2). Intramolecular competition studies exemplified a synthetically useful site-selectivity at the less congested C-6 position of 5-aryl- $1 H$-tetrazoles with a meta substitution pattern in substrates $\mathbf{6 8 c}$, $68 \mathbf{e}$ and 68g (entries 3, 5 and 7). Moreover, the para-substituted tetrazole 68d was productively converted but minor effective towards meta-substituted substrate $68 \mathrm{c}$ in the appropriate orthoarylated product 69da (entry 4). Unfortunately, tetrazolyl-substituted arenes 68 with decreased electron density induced by electron-withdrawing groups displayed no reactivity (entries 8-10), which indicates that a formal oxidative addition of the aryl chloride to the ruthenium complex is the rate-determining step. Subsequently, the $\mathrm{C}-\mathrm{H}$ transformation with respect to (hetero)aryl chlorides $\mathbf{5 9}$ was investigated. Fortunately, the electronic nature of the aryl electrophiles $\mathbf{5 9}$ had little impact on this process and both electron-poor as well as more challenging electron-rich substrates were readily applied to the direct functionalization. Furthermore, heteroaryl chloride 59e furnished the $\mathrm{C}-\mathrm{H}$ arylated product 69ce in a reasonable yield (entry 14). The user-friendly ruthenium(II) catalyst presented an excellent chemoselectivity in relation to expedient electrophilic functional groups, such as enolizable ketone, ester, ether or thioether substituents, offering a great possibility to late-stage diversification.

Table 21: Scope of C-H arylation of 5-aryl-1H-tetrazole 68 with aryl chlorides 59. ${ }^{\text {[a] }}$

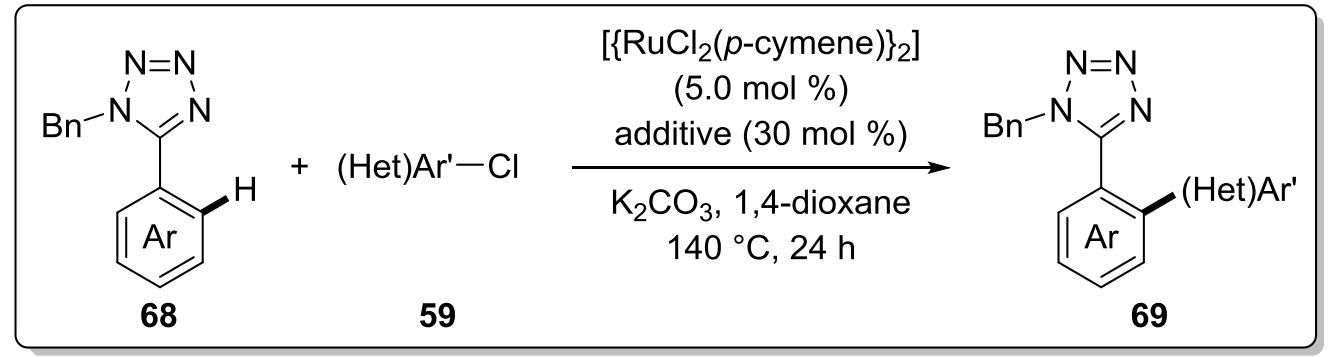

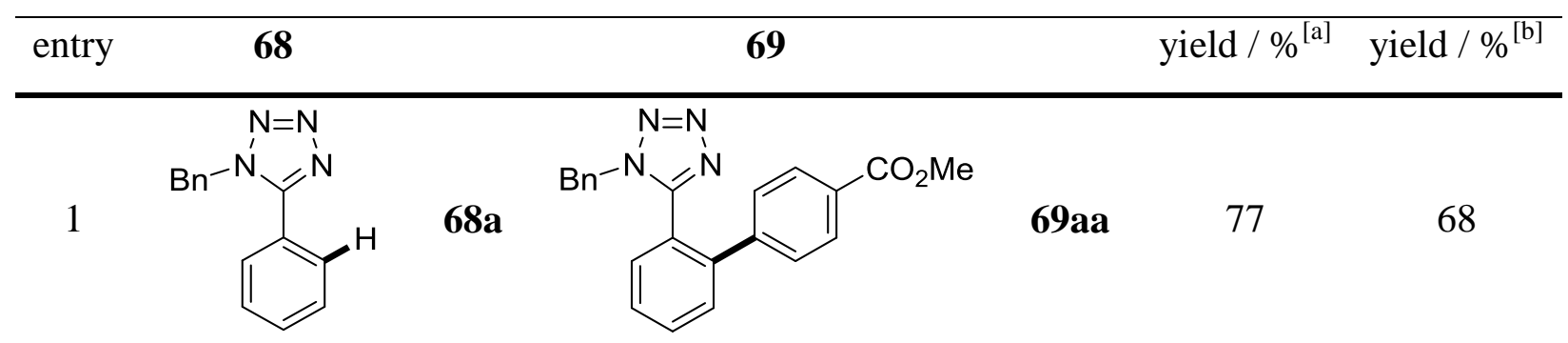


<smiles>Cc1ccccc1-c1nnnn1Cc1ccccc1</smiles>

$68 b$<smiles>CC(=O)c1ccc(-c2cccc(C)c2-c2nnnn2Cc2ccccc2)cc1</smiles>

69ba

3<smiles>Cc1cccc(-c2nnnn2Cc2ccccc2)c1</smiles>

4<smiles>Cc1ccc(-c2nnnn2Cc2ccccc2)cc1</smiles>

5<smiles>COc1cccc(-c2nnnn2Cc2ccccc2)c1</smiles>

6<smiles>COc1ccc(-c2nnnn2Cc2ccccc2)cc1</smiles>

7<smiles>c1ccc(Cn2nnnc2-c2ccc3ccccc3c2)cc1</smiles>

8<smiles>FC(F)(F)c1cccc(-c2nnnn2Cc2ccccc2)c1</smiles>

$68 c$<smiles>CC(=O)c1ccc(-c2ccc(C)cc2-c2nnnn2Cc2ccccc2)cc1</smiles>

68d<smiles>CC(=O)c1ccc(-c2cc(C)ccc2-c2nnnn2Cc2ccccc2)cc1</smiles>

$68 \mathrm{e}$<smiles>COc1ccc(-c2ccc(C(C)=O)cc2)c(-c2nnnn2Cc2ccccc2)c1</smiles>

$68 f$<smiles>COC(=O)c1ccc(-c2nnnn2Cc2ccccc2)c(-c2ccc(OC)cc2)c1</smiles>

$68 g$<smiles>CC(=O)c1ccc(-c2cc3ccccc3cc2-c2nnnn2Cc2ccccc2)cc1</smiles>

69ga
$68 h$<smiles>CC(=O)c1ccc(-c2ccc(C(F)(F)F)cc2-c2nnnn2Cc2ccccc2)cc1</smiles>

81

69da 62

53

69ea 59

51

69fa $\quad 70$

61 
9<smiles>FC(F)(F)c1ccc(-c2nnnn2Cc2ccccc2)cc1</smiles>

$68 \mathrm{i}$<smiles>CC(=O)c1ccc(-c2cc(C(F)(F)F)ccc2-c2nnnn2Cc2ccccc2)cc1</smiles>

69ia

68j<smiles>CC(=O)c1ccc(-c2ccc(F)cc2-c2nnnn2Cc2ccccc2)cc1</smiles>

68c<smiles>CC(=O)c1ccc(-c2ccc(C)cc2-c2nnnn2Cc2ccccc2)cc1</smiles>

$69 \mathrm{cb}$

83

77<smiles>COc1ccc(-c2ccc(C)cc2-c2nnnn2Cc2ccccc2)cc1</smiles>

$69 \mathrm{cc}$

84

75<smiles>Cc1ccc(-c2ccc(C)cc2-c2nnnn2Cc2ccccc2)cc1</smiles>

69cd 64

56

69ce

67

14

$68 c$<smiles>Cc1cccc(-c2nnnn2Cc2ccccc2)c1</smiles><smiles>Cc1ccc(-c2ccsc2)c(-c2nnnn2Cc2ccccc2)c1</smiles>

${ }^{[a]}$ General reaction conditions: $68(0.30 \mathrm{mmol}), \quad 59(0.90 \mathrm{mmol}),\left[\left\{\mathrm{RuCl}_{2}(p \text {-cymene })\right\}_{2}\right] \quad(5.0 \mathrm{~mol} \%)$, Piv-Val-OH $(30 \mathrm{~mol} \%), \mathrm{K}_{2} \mathrm{CO}_{3}(0.90 \mathrm{mmol}), 1$,4-dioxane $(0.3 \mathrm{~mL}), 140{ }^{\circ} \mathrm{C}, 24 \mathrm{~h}$; isolated yields. ${ }^{[\mathrm{b}]} \mathbf{6 8}$ $(0.30 \mathrm{mmol}), \mathbf{5 9}(0.90 \mathrm{mmol}),\left[\left\{\mathrm{RuCl}_{2}(p \text {-cymene })\right\}_{2}\right](5.0 \mathrm{~mol} \%), \mathrm{MesCO}_{2} \mathrm{H}(30 \mathrm{~mol} \%), \mathrm{K}_{2} \mathrm{CO}_{3}(0.90 \mathrm{mmol})$, 1,4-dioxane $(0.3 \mathrm{~mL}), 140{ }^{\circ} \mathrm{C}, 24 \mathrm{~h}$; isolated yields. 
The outstanding potential of the developed catalytic system for $\mathrm{C}-\mathrm{H}$ arylation was emphasized by the promising direct synthesis of the protected blockbuster drug Valsartan 69at with aryl chloride 59t as the electrophilic arylating reagent (Scheme 32).

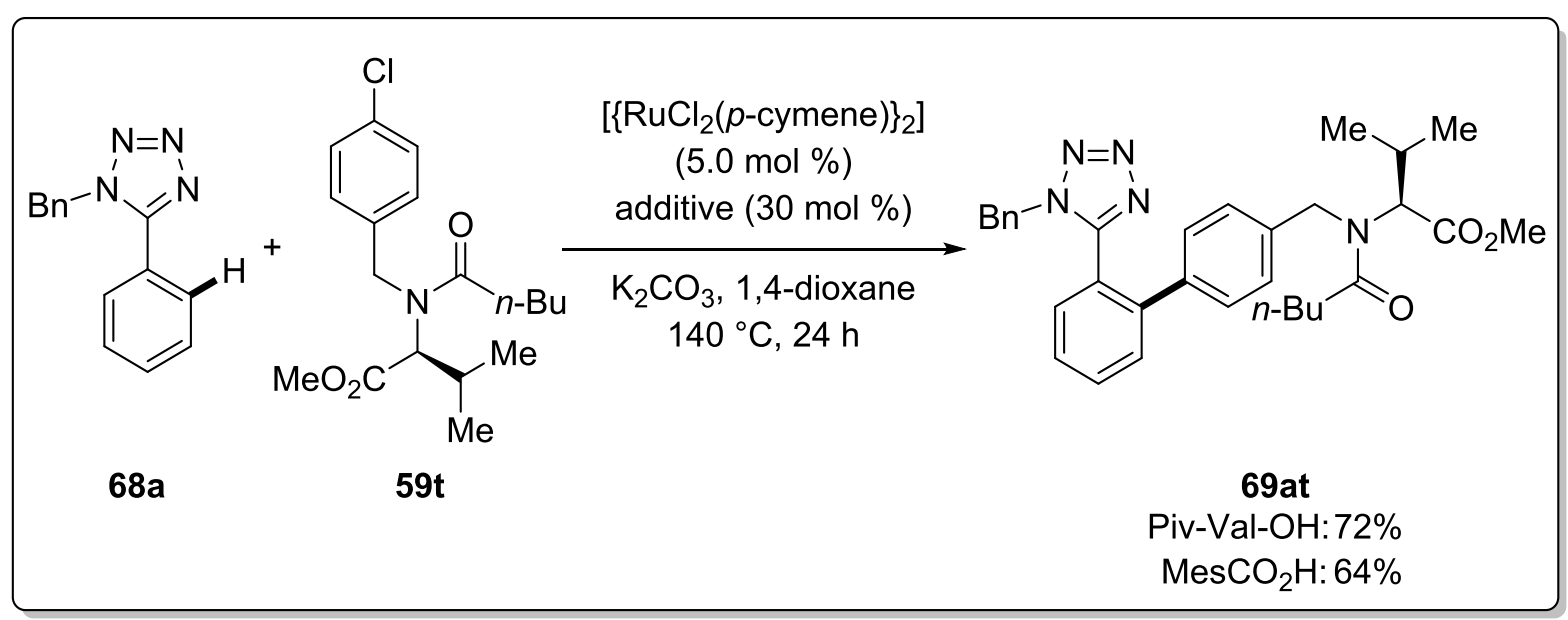

Scheme 32: Step-economical access of protected Valsartan 69at via C-H arylation.

In addition, different aryl-(pseudo)halides $\mathbf{7 2}$ were screened as electrophiles. The reaction conditions were not convenient for the aryl mesylate and tosylate (entries 1-4). However, aryl chloride, bromide and iodide as well as phenol-derived aryl triflate were found to be compatible in this protocol supplying moderate to excellent yields (Table 22, entries 5-12). ${ }^{[105]}$

Table 22: Scope of aryl-(pseudo)halides 72 as electrophiles. ${ }^{[a]}$

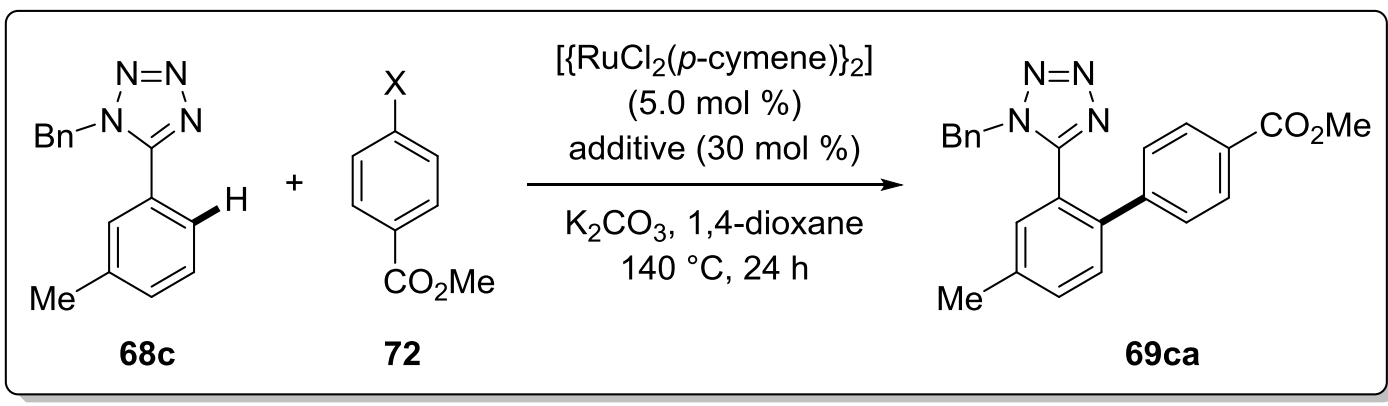

\begin{tabular}{cccc}
\hline entry & $\mathrm{X}$ & additive & yield / \% \\
\hline 1 & OMs & Piv-Val-OH & --- \\
2 & OMs & MesCO$_{2} \mathrm{H}$ & -- \\
3 & OTs & Piv-Val-OH & -- \\
4 & OTs & MesCO & $\mathrm{H}$ \\
5 & OTf & Piv-Val-OH & ---
\end{tabular}




\begin{tabular}{cccc}
\hline 6 & OTf & MesCO $_{2} \mathrm{H}$ & 51 \\
7 & $\mathrm{Cl}$ & $\mathrm{Piv}-\mathrm{Val}-\mathrm{OH}$ & 89 \\
8 & $\mathrm{Cl}$ & $\mathrm{MesCO}_{2} \mathrm{H}$ & 81 \\
9 & $\mathrm{Br}$ & $\mathrm{Piv}-\mathrm{Val}-\mathrm{OH}$ & 97 \\
10 & $\mathrm{Br}$ & $\mathrm{MesCO} \mathrm{C}_{2} \mathrm{H}$ & 95 \\
11 & $\mathrm{I}$ & $\mathrm{Piv}-\mathrm{Val}_{-} \mathrm{OH}$ & 96 \\
12 & $\mathrm{I}$ & $\mathrm{MesCO}_{2} \mathrm{H}$ & 95 \\
\hline
\end{tabular}

${ }^{[a]}$ General reaction conditions: $\mathbf{6 8 c}(0.30 \mathrm{mmol}), \mathbf{7 2}(0.90 \mathrm{mmol}),\left[\left\{\mathrm{RuCl}_{2}(p \text {-cymene })\right\}_{2}\right](5.0 \mathrm{~mol} \%)$, additive (30 mol \%), $\mathrm{K}_{2} \mathrm{CO}_{3}(0.90 \mathrm{mmol})$, 1,4-dioxane $(0.3 \mathrm{~mL}), 140{ }^{\circ} \mathrm{C}, 24 \mathrm{~h}$; isolated yields.

The importance of the $\mathrm{C}-\mathrm{H}$ activation approach is among others reflected by the expedient access to molecular frameworks of blockbuster drugs. Based on this powerful strategy, the protected antihypertension drug Valsartan 69at was prepared in excellent yield utilizing 4-bromo aryl amino acid derivative 52f as coupling partner (Scheme 33). This environmentally friendly and sustainable $\mathrm{C}-\mathrm{C}$ bond formation illustrated a great opportunity for commercial industrial applications in a sustainable mode.

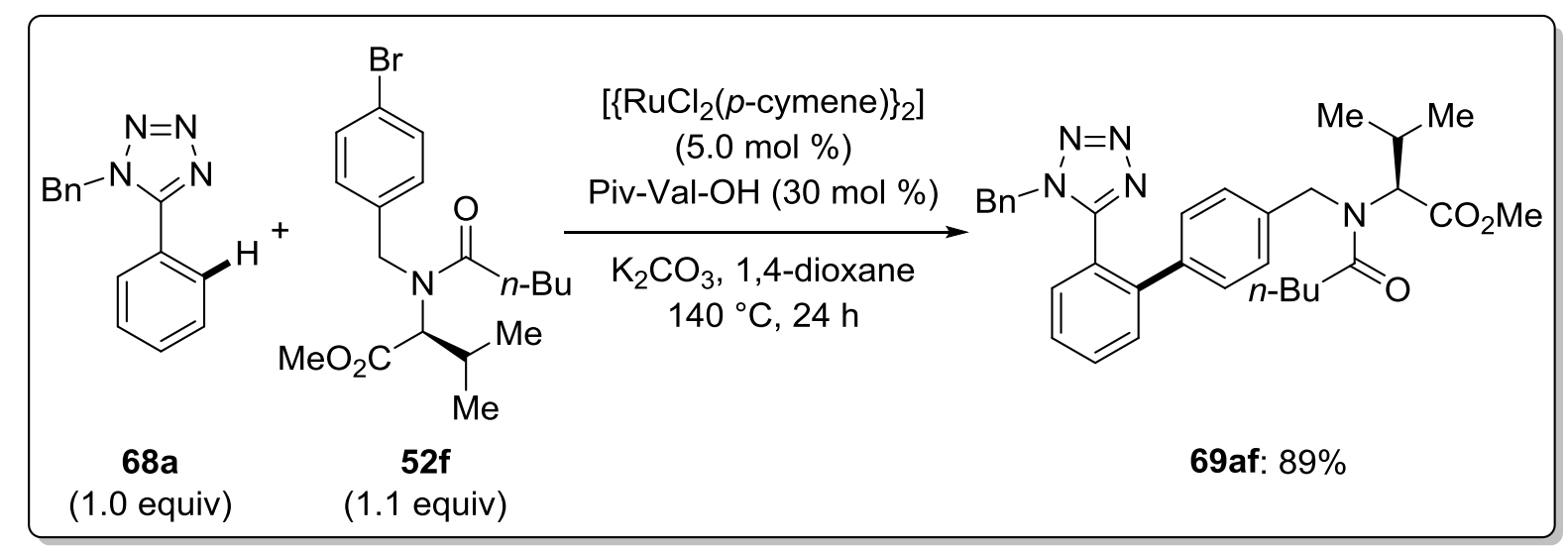

Scheme 33: Practical synthesis of protected Valsartan 69at via $\mathrm{C}-\mathrm{H}$ arylation. 


\subsubsection{Mechanistic studies}

\subsubsection{Experiments with radical scavengers}

In the presence of stoichiometric amounts of radical scavengers under otherwise identical reaction conditions the $\mathrm{C}-\mathrm{H}$ transformation completely failed to provide the desired $\mathrm{C}-\mathrm{H}$ arylated product 69aa (Table 23). Therefore, a SET-type C-X activation via homolytic bond cleavage is suggested to be operating in this system. ${ }^{[131]}$

Table 23: Influence of radical scavengers in the $\mathrm{C}-\mathrm{H}$ arylation process. ${ }^{[\mathrm{a}]}$

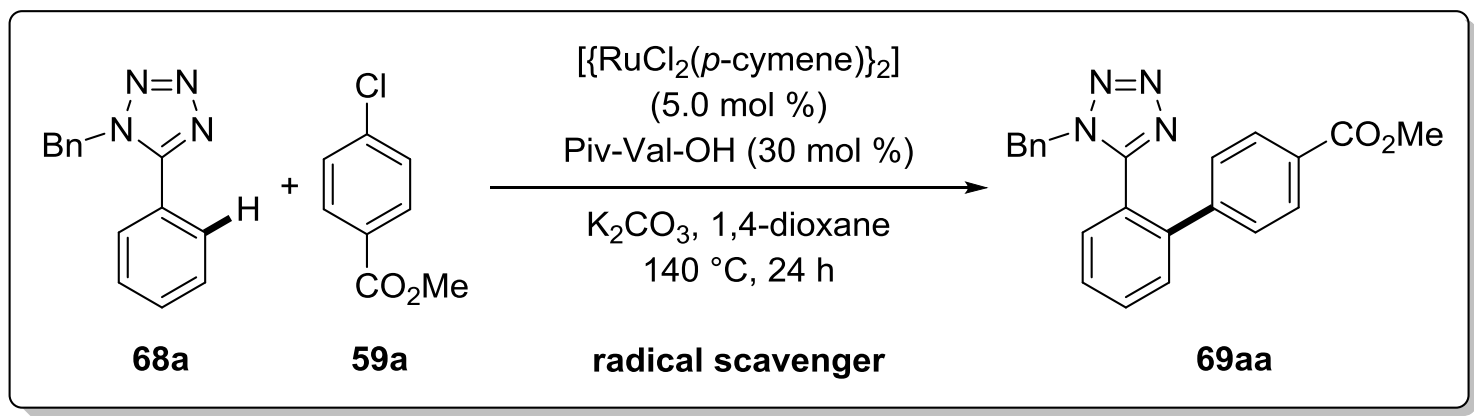

\begin{tabular}{ccc}
\hline entry & radical scavenger & yield / \% \\
\hline 1 & --- & $80^{[\mathrm{b}]}$ \\
2 & TEMPO & -- \\
4 & $\mathrm{Ph}_{2} \mathrm{C}=\mathrm{CH}_{2}$ & -- \\
\hline
\end{tabular}

${ }^{[a]}$ General reaction conditions: 68a $(0.30 \mathrm{mmol}), \quad 59 a \quad(0.90 \mathrm{mmol}), \quad\left[\left\{\mathrm{RuCl}_{2}(p \text {-cymene })\right\}_{2}\right] \quad(5.0 \mathrm{~mol} \%)$, Piv-Val-OH (30 mol \%), $\mathrm{K}_{2} \mathrm{CO}_{3}(0.90 \mathrm{mmol}), 1$,4-dioxane $(0.3 \mathrm{~mL})$, radical scavenger $\left(1.0\right.$ equiv), $140{ }^{\circ} \mathrm{C}, 24 \mathrm{~h}$; isolated yields. ${ }^{[\mathrm{b}]} 10 \%$ of diarylated product 69aa' was also isolated. TEMPO $=2,2,6,6$-tetramethylpiperidine 1 oxyl, BHT = butylated hydroxytoluene. 


\subsubsection{Initial rate comparison}

The mechanistic observation depicted a substantial initial rate acceleration affected by the pre-ligands for the formation of 69aa (Figure 5). Piv-Val-OH and $\mathrm{MesCO}_{2} \mathrm{H}$ exhibited a high initial rate, when compared to an experiment performed in the absence of the co-catalytic additive.
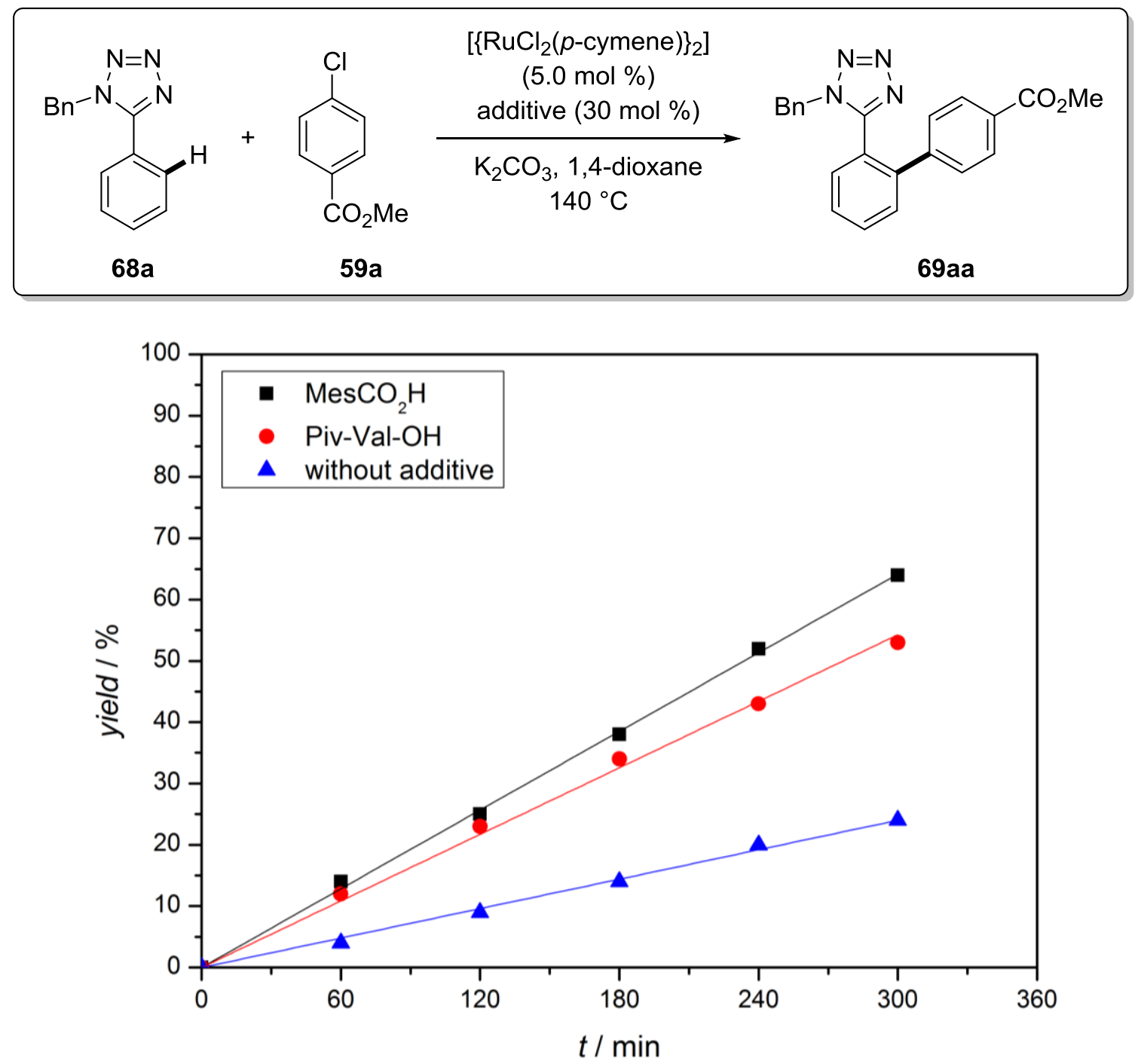

Figure 5: Initial rate comparison with and without additives. 


\subsubsection{Comparison of the kinetic reaction profile}

In the initial stage of the reaction, the in situ formed ruthenium(II)-carboxylate complex has a faster rate versus the ruthenium(II)-MPAA complex (Figures 5 and 6). After a reaction time of approximately $5 \mathrm{~h}$, deactivation-type behaviour was recognized for the carboxylate catalyst, resulting in superior yields being achieved after $24 \mathrm{~h}$ with the ruthenium(II)-MPAA catalyst, reflecting its long-term catalyst stability (Figure 6).
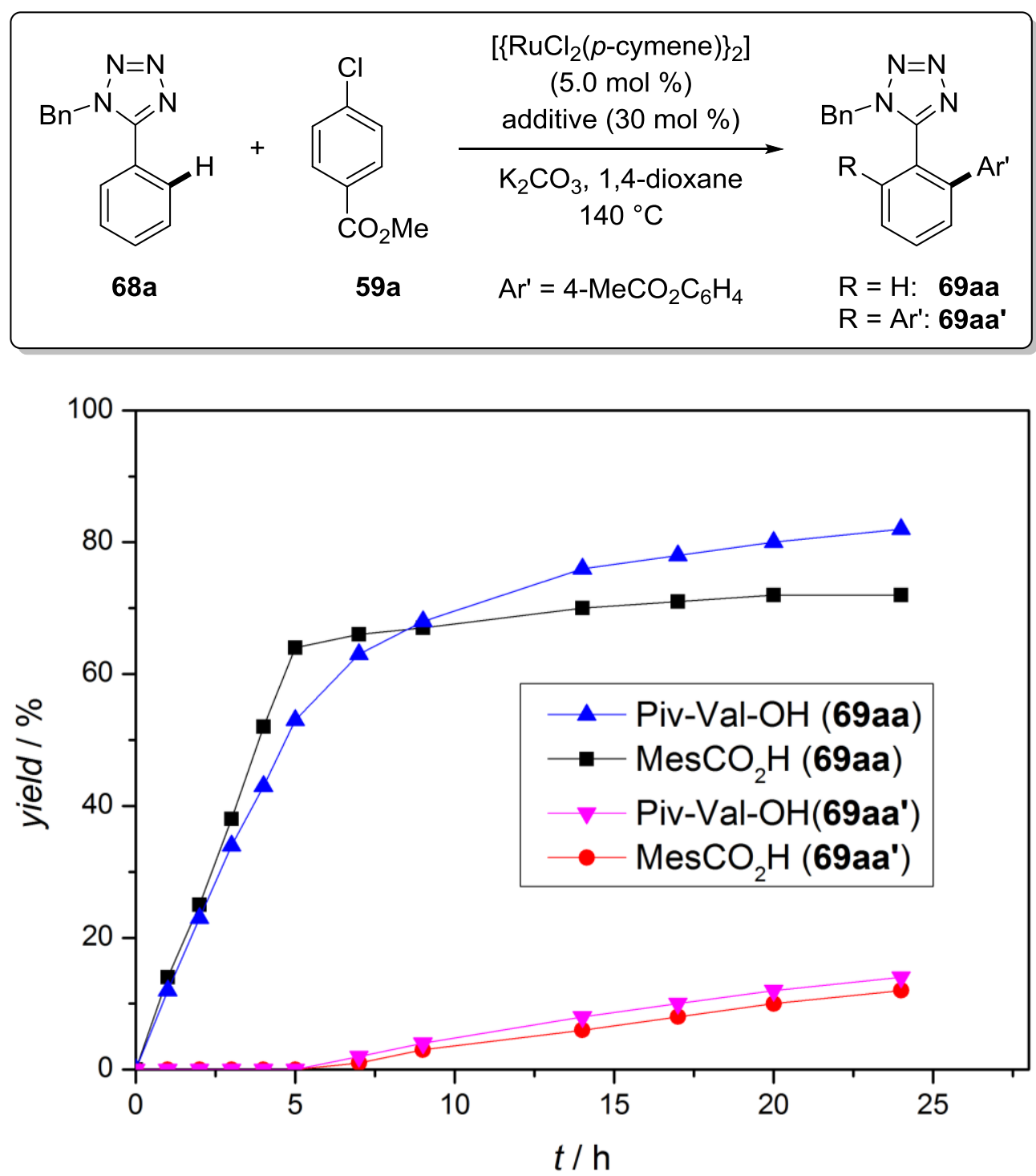

Figure 6: Comparison of the kinetic reaction profile between $\mathrm{MesCO}_{2} \mathrm{H}$ and $\mathrm{Piv}-\mathrm{Val}-\mathrm{OH}$ as pre-ligands. 


\subsubsection{Proposed catalytic cycle}

In relation to the previous findings on ruthenium(II)-catalyzed direct $\mathrm{C}-\mathrm{H}$ arylations through chelation assistance, the catalytic cycle commences by in situ formation of the ruthenium(II)MPAA complex 90 (Scheme 34). The active catalyst complex 90 generates in a reversible redox-neutral ortho- $\mathrm{C}-\mathrm{H}$ ruthenation the cycloruthenated complex 93 through a sixmembered inner-sphere concerted ruthenation-deprotonation transition state 92. ${ }^{[7,107,146]}$ Here, it is proposed that the amino acid facilitates the $\mathrm{C}-\mathrm{H}$ bond cleavage serving as a catalytic proton shuttle from the transition state of the CMD process to the insoluble carbonate base. ${ }^{[107,146,157]}$ Subsequently, formal oxidative addition of the aryl electrophile $\mathbf{7 2}$ by a SETtype $\mathrm{C}-\mathrm{X}$ activation provides the ruthenium(IV) species 94. Finally, reductive elimination liberates the desired $\mathrm{C}-\mathrm{H}$ functionalized product $\mathbf{6 9}$ and regenerates the active catalyst $\mathbf{9 0 .}$

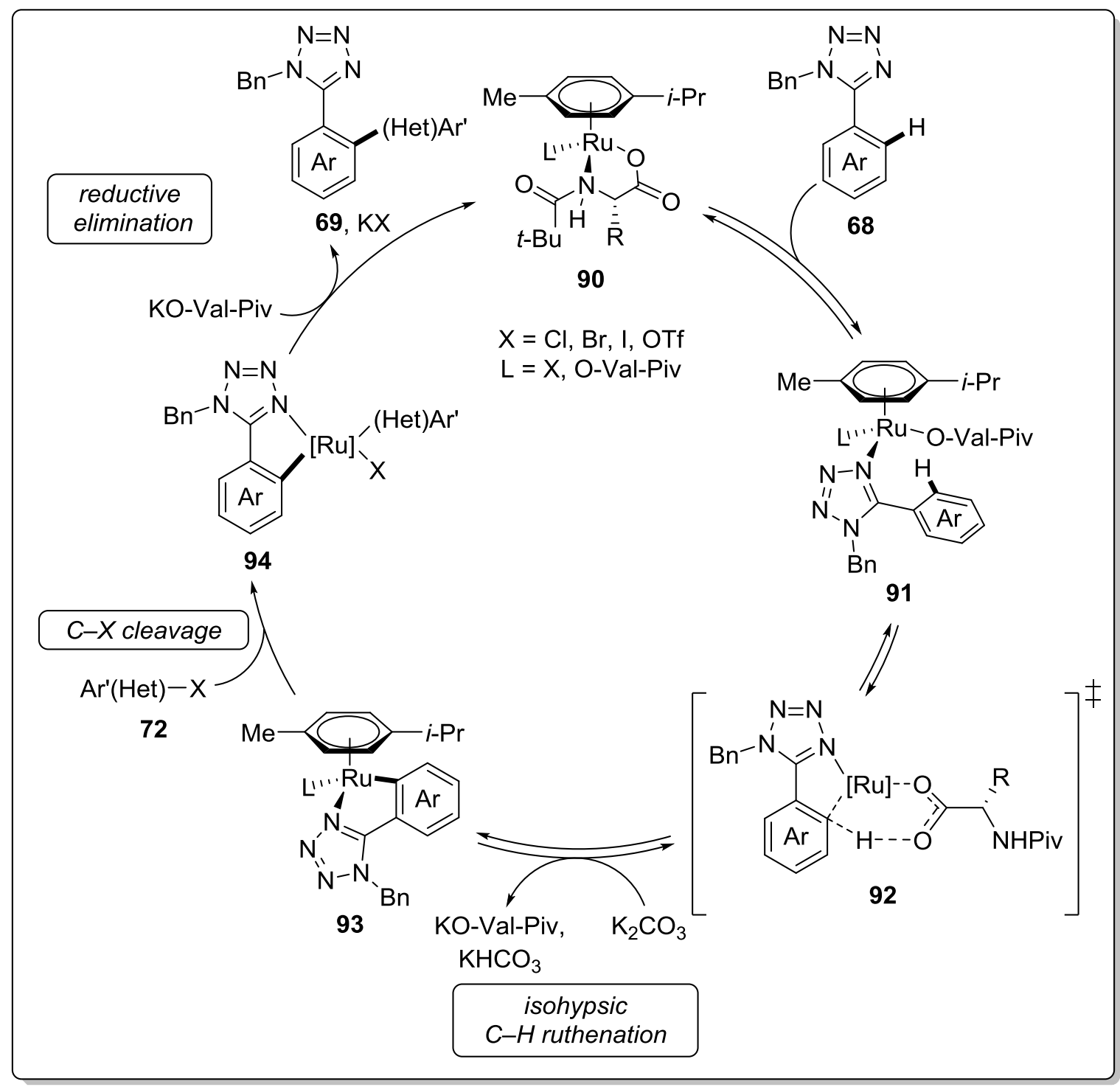

Scheme 34: Proposed catalytic cycle for the C-H arylation. 


\section{Summary and Outlook}

Biaryls are key structural motifs of numerous bioactive compounds of relevance to agrochemicals and drugs, among others. Transition metal-catalyzed direct functionalization processes of otherwise inert $\mathrm{C}-\mathrm{H}$ bonds emerged as a more sustainable alternative to the classically used cross-coupling reactions for the synthesis of biaryls. For this reason, the research was focused on the development of novel methods for efficient and selective direct $\mathrm{C}-\mathrm{H}$ transformations to construct biaryl scaffolds in an atom- and step-economical manner.

The first part of this thesis described an efficient and generally applicable method for the ruthenium(II)-catalyzed oxidative $\mathrm{C}-\mathrm{H}$ arylation of anilides $\mathbf{3 0}$ accomplished with boron-based arylating reagents 95 (Scheme 35). The high activity of the catalytic system was not restricted to boronic acids $\mathbf{7 3}$ as coupling partners, but enabled the first ruthenium(II)catalyzed direct arylations using borinic acids $\mathbf{7 6}$ or potassium trifluoroborates $\mathbf{7 7}$. An in situ generated cationic ruthenium(II) catalyst promoted the highly chemo- and mono-selective $\mathrm{C}-\mathrm{H}$ funtionalization in excellent yields with a broad substrate scope. Here, electron-donating and -withdrawing groups on the arene of both anilides and aromatic boron-based reagents were compatible with this transformation to set the stage after removal of the acyl group for valuable 2-aminobiaryls, which are key structural frameworks in drugs and crop protection agents. $^{[163]}$ 


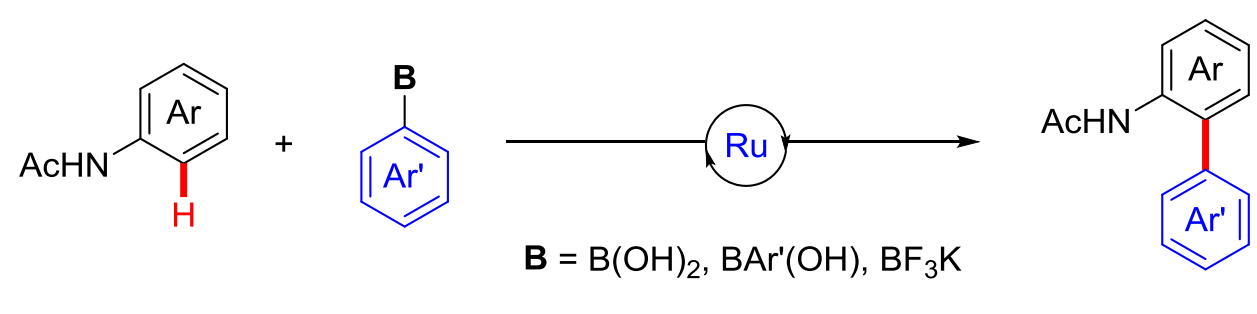

30

95

33

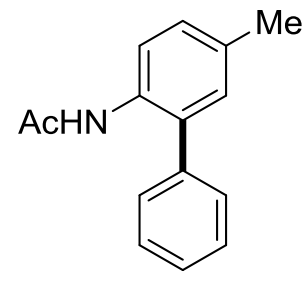

33ja: $79 \%$ [B(OH $\left.)_{2}\right]$<smiles>CCNc1ccc(F)cc1-c1ccccc1</smiles>

33qa: $71 \%$

[B(OH $\left.)_{2}\right]$<smiles>CC(=O)Nc1ccc(C(C)=O)cc1-c1ccccc1</smiles>

33ta: $58 \%$

[B(OH $\left.)_{2}\right]$<smiles>COc1ccc(-c2ccccc2NC(C)C)cc1</smiles><smiles>CCNc1ccc(OC)cc1-c1ccc(C)cc1</smiles>

33ad: $62 \%$

[BAr'(OH)] 33lb: $56 \%$

$\left[\mathrm{BF}_{3} \mathrm{~K}\right]$

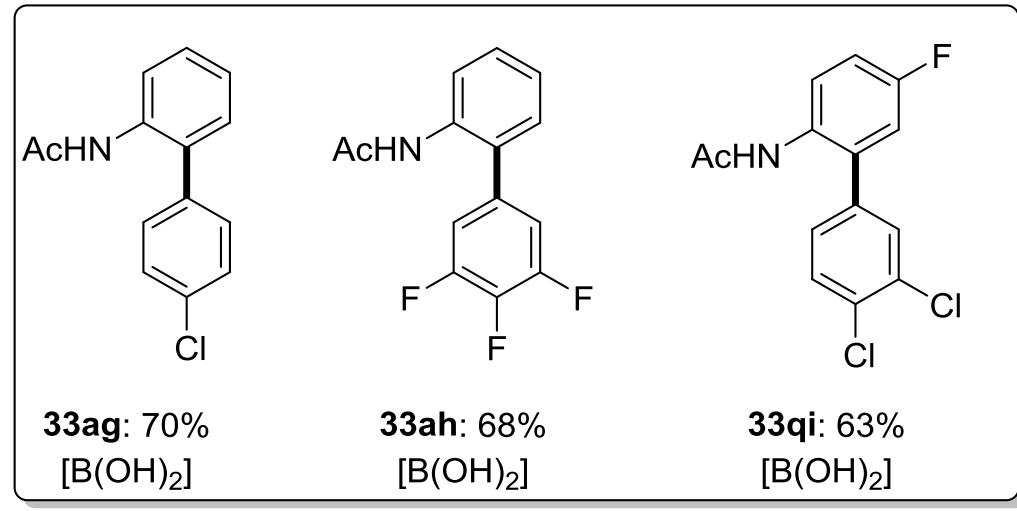

Scheme 35: Ruthenium(II)-catalyzed ortho-C-H arylation of anilides $\mathbf{3 0}$ with boron-based arylating reagents $\mathbf{9 5}$.

From a synthetic point of view, a considerable application for 2-aminobiaryls is reflected by the manufacture of fungicides. ${ }^{[137-139]}$

Prospective investigations could be addressed to isohypsic catalytic systems for $\mathrm{C}-\mathrm{H}$ arylations of anilides employing aryl halides as electrophilic coupling partners. The overall redox-neutral $\mathrm{C}-\mathrm{H}$ functionalizations proceed in the absence of stoichiometric metal salts as terminal oxidant in contrast to the oxidative processes, which is desirable for sustainable chemistry. 
The second project represented the first isohypsic $\mathrm{C}-\mathrm{H}$ arylation of azoarenes $\mathbf{1 3}$ by carboxylate assistance (Scheme 36). The direct arylation was consistent with electrondeficient as well as electron-rich (hetero)aryl halides $\mathbf{6 3}$ as electrophilic coupling partners delivering the desired ortho-arylated azoarenes 83. Notably, the catalytic system showed high levels of chemo- and site-selectivity with an ample substrate scope. The broad functional group tolerance demonstrates to be convenient for further late-stage diversifications.

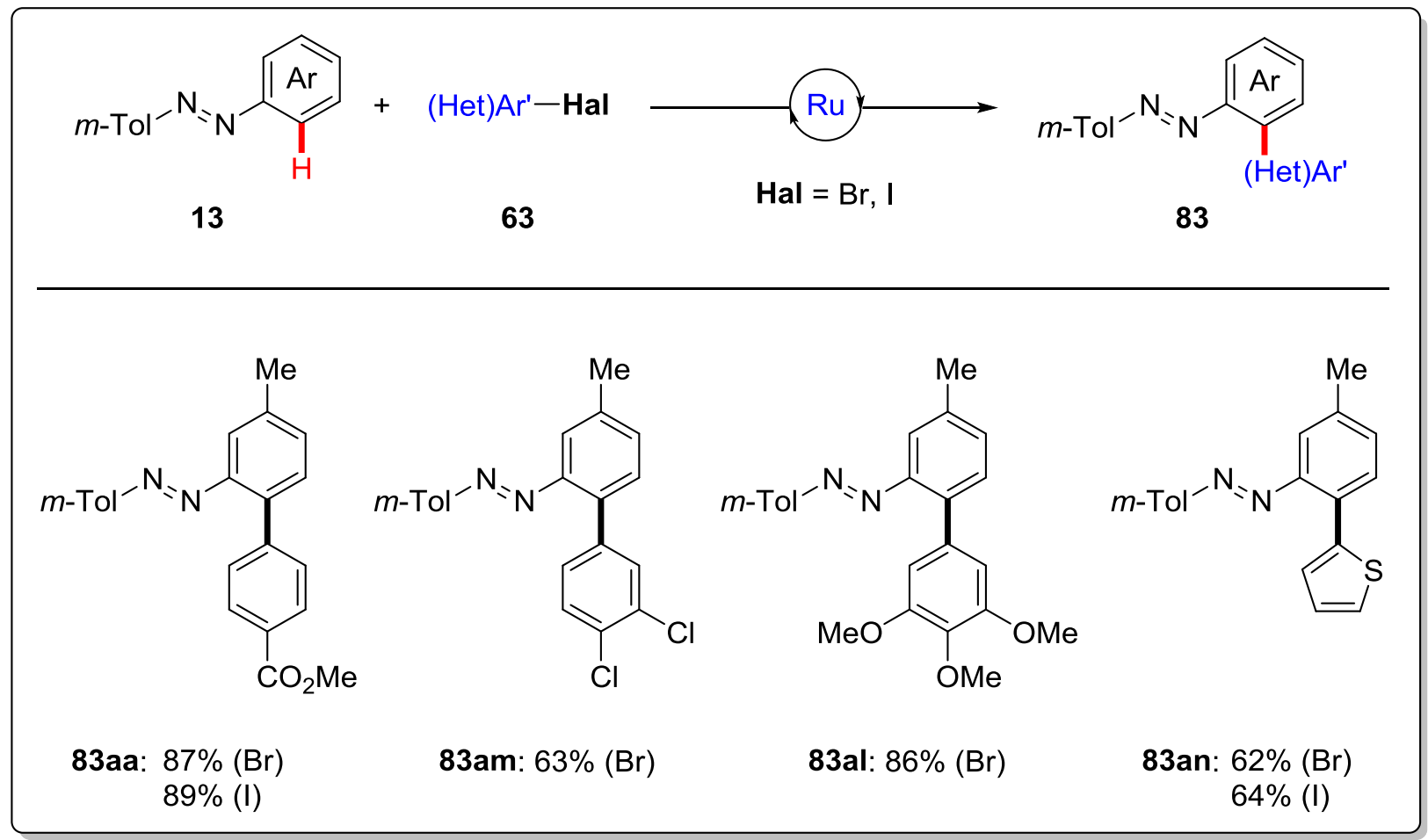

Scheme 36: Ruthenium(II)-catalyzed C-H arylation of azoarenes 13 with (hetero)aryl halides $\mathbf{7 2 .}$

A straightforward one-pot synthesis starting from azoarene $\mathbf{1 3}$ by applying $\mathrm{C}-\mathrm{H}$ arylation as the key reaction and subsequent reduction of the azo group provides the corresponding synthetically useful 2-aminobiaryl 34 in a highly economical manner (Scheme 37). ${ }^{[164]}$ 


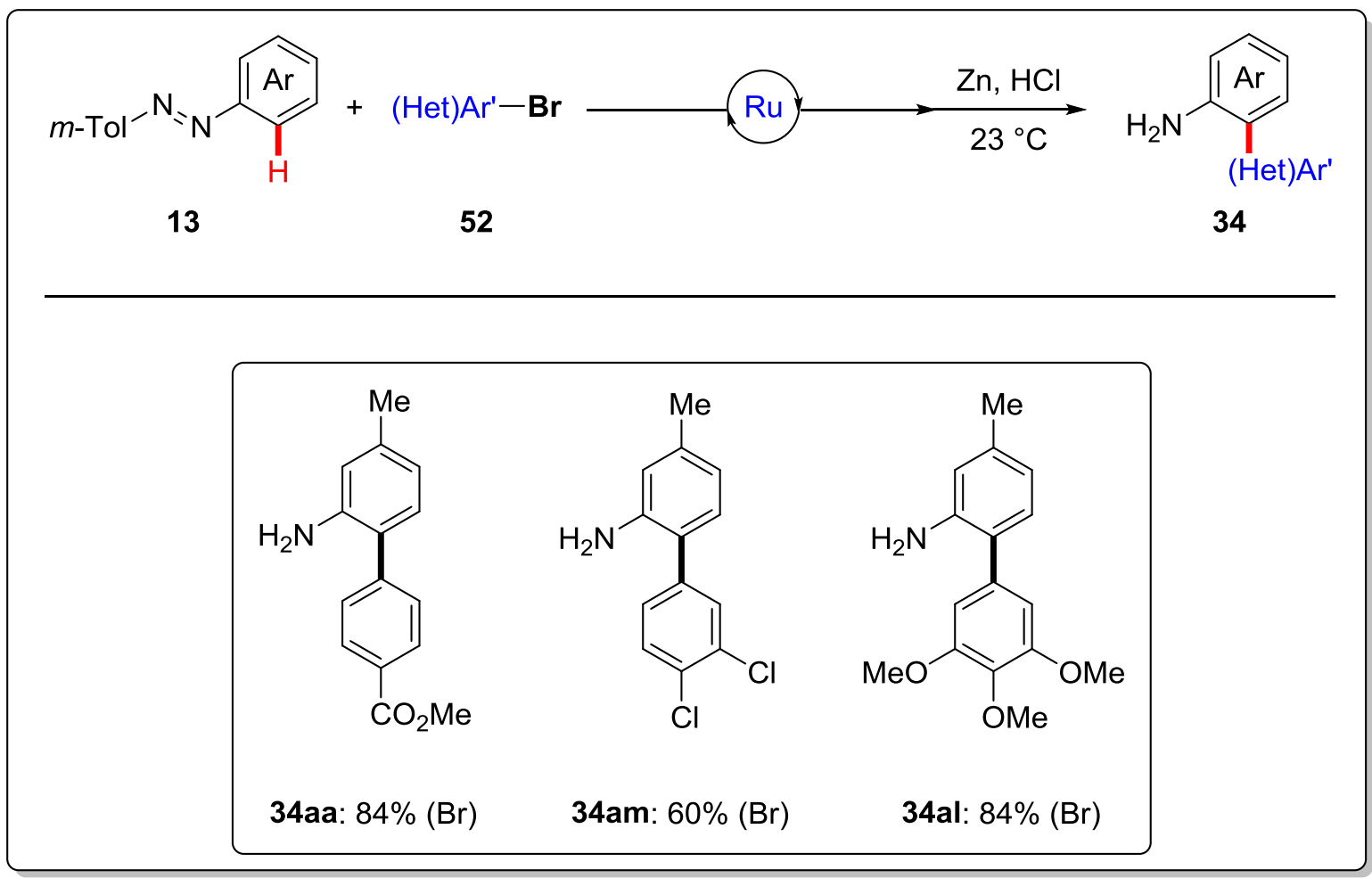

Scheme 37: Straightforward method to achieve access to ortho-arylated anilines 34.

The development of direct 2,2'-C-H diarylation of azoarenes and subsequent reduction of the azo group in an one-pot process to afford twice the desired ortho-arylated anilines is of particular interest in relation to the atom- and step-economy.

The research was further focused on the improvement of redox-neutral ruthenium(II)catalyzed $\mathrm{C}-\mathrm{H}$ arylation systems. Here, an unprecedented highly efficient $\mathrm{C}-\mathrm{H}$ functionalization of 5-aryl- $1 H$-tetrazoles $\mathbf{6 8}$ deploying readily available and cost-effective aryl chlorides 59 is illustrated in Scheme 38. Optimal outcomes were achieved for a range of tetrazoles 68 with Piv-Val-OH as the pre-ligand of choice to facilitate the $\mathrm{C}-\mathrm{H}$ activation. The outstanding performance of the in situ generated ruthenium(II) amino acid catalyst resulted from the increased long-term stability, which was revealed in a comparative kinetic study. The novel catalytic system was characterized by a broad substrate scope including various aryl electrophiles $\mathbf{7 2}$ with an excellent chemo- and site-selectivity affording the desired biaryl tetrazoles 69, which are contained as essential framework of blockbuster antihypertension drugs. 
The practical importance of the $\mathrm{C}-\mathrm{H}$ activation strategy was reflected by the direct synthesis of the protected angiotensin II receptor blocker Valsartan 69at in a highly step-economical fashion, which should prove beneficial in the industrial sector. ${ }^{[165]}$

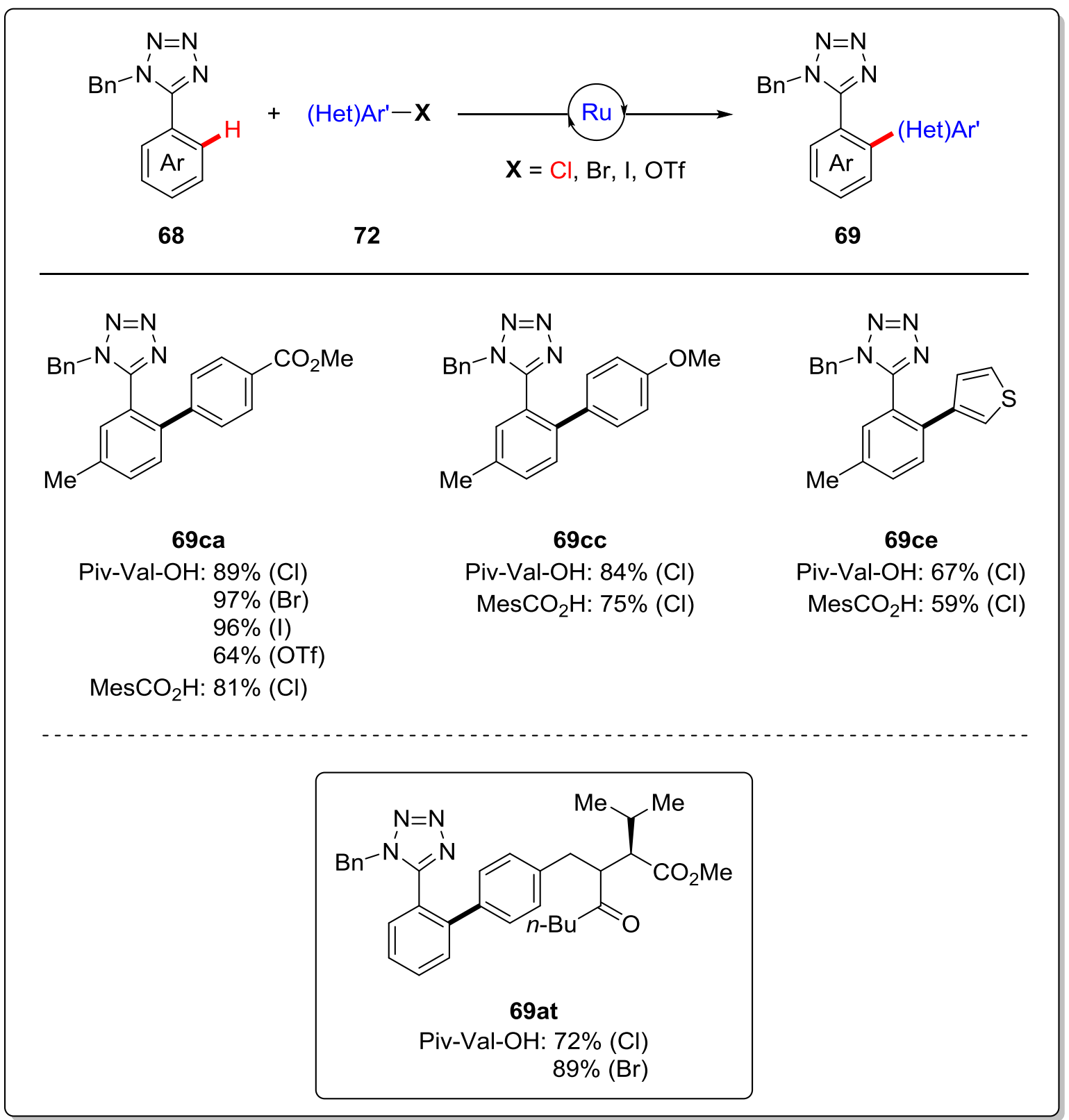

Scheme 38: Expedient access to antihypertension drugs via ruthenium(II)-catalyzed $\mathrm{C}-\mathrm{H}$ arylation of tetrazoles.

These findings highlight the great significance of pre-ligands to improve the robustness, reactivity and selectivity of ruthenium(II) catalysts for $\mathrm{C}-\mathrm{H}$ activation, which was realised using mono- $N$-protected $\alpha$-amino acids. The next challenging level is to take advantage of the chiral amino acid ligands for asymmetric $\mathrm{C}-\mathrm{H}$ transformations based on ruthenium catalysis. 


\section{Experimental Section}

\subsection{General Remarks}

All reactions involving moisture- or air-sensitive reagents or products were conducted under an atmosphere of nitrogen, using standard Schlenk techniques and pre-dried glassware. Syringes for handling of dry solvents or liquid reagents were evacuated and purged with nitrogen threefold prior to use. Analytical data of substances that are known in the literature were compared with those described in the literature.

\subsubsection{Solvents}

All solvents for reactions were purified using a MBRAUN Solvent Purification System 800 (MB SPS 800) or were dried, degassed, distilled and stored under an inert atmosphere (argon or nitrogen) according to following standard procedures.

$t$-Amyl alcohol $(t-\mathrm{AmOH})$ was dried over $\mathrm{Na}$ for $5 \mathrm{~h}$ and distilled under ambient pressure.

$t$-Butyl alcohol $(t-\mathrm{BuOH})$ was dried over $\mathrm{Na}$ and distilled under ambient pressure and stored over molecular sieves (4 A).

1,2-Dichloroethane (DCE) was dried over $\mathrm{CaH}_{2}$ for $8 \mathrm{~h}$ and distilled under ambient pressure.

1,2-Dimethoxyethane (DME) was dried over $\mathrm{Na}$ for $12 \mathrm{~h}$ and distilled over $\mathrm{Na} /$ benzophenone under ambient pressure.

$N, N$-Dimethylacetamide (DMA) was dried over $\mathrm{CaH}_{2}$ and distilled under reduced pressure.

$N, N$-Dimethylformamide (DMF) was dried over $\mathrm{CaH}_{2}$ for $8 \mathrm{~h}$ and distilled under reduced pressure.

1,4-Dioxane was dried over $\mathrm{Na}$ for $12 \mathrm{~h}$ and distilled over $\mathrm{Na} /$ benzophenone under ambient pressure. 
Methanol $(\mathrm{MeOH})$ was dried over $\mathrm{Mg}(\mathrm{OEt})_{2}$ for $3 \mathrm{~h}$ and distilled under ambient pressure.

$N$-Methyl-2-pyrrolidone (NMP) was stirred for $6 \mathrm{~h}$ in $\mathrm{CaH}_{2}$ and subsequently distilled under reduced pressure.

Tetrahydrofuran (THF) was purified using a MB SPS 800 and distilled under ambient pressure.

Toluene $(\mathrm{PhMe})$ was dried over $\mathrm{Na}$ and distilled over $\mathrm{Na}$ /benzophenone under ambient pressure.

Water $\left(\mathrm{H}_{2} \mathrm{O}\right)$ was degassed for $2 \mathrm{~h}$ and ultrasonicated.

$\boldsymbol{o}$-Xylene was distilled over $\mathrm{Na} / \mathrm{benzophenone} \mathrm{under} \mathrm{reduced} \mathrm{pressure.}$

\subsubsection{Vacuum}

Following pressures were measured on the used vacuum pumps and are not corrected: membrane pump vacuum (MPV): 5.0 mbar, oil pump vacuum (OPV): 0.1 mbar.

\subsubsection{Melting Point}

Melting points were measured using a Stuart ${ }^{\circledR}$ Melting Point Apparatus SMP3 (Barloworld Scientific).

\subsubsection{Chromatography}

Analytical TLC was performed on $0.25 \mathrm{~mm}$ silica gel 60F plates (Macherey-Nagel) with $254 \mathrm{~nm}$ fluorescent indicator from Merck. Plates were visualized under ultraviolet light. Chromatographic purification of products was accomplished by flash column chromatography on Merck silica gel, grade 60 (0.040-0.063 mm and 0.063-0.200 mm, 70-230 mesh ASTM). 


\subsubsection{Gas Chromatography}

Monitoring of the reaction progress via coupled gas chromatography-mass spectrometry was performed using Hewlett-Packard G1800C GCDplus with mass detector HP 5971, 5890 Series II with mass detector HP 5972 and Agilent Technologies 7890A GC-System with mass detector $5975 C$ (Triplex-Axis-Detector). HP-5MS columns $(30 \mathrm{~m} \times 0.25 \mathrm{~mm}$, film $0.25 \mu \mathrm{m})$ were used.

\subsubsection{Nuclear Magnetic Resonance Spectroscopy}

Nuclear magnetic resonance (NMR) spectra were recorded at $300,400,500,600 \mathrm{MHz}$ $\left({ }^{1} \mathrm{H}-\mathrm{NMR}\right)$, at $75,126 \mathrm{MHz}\left({ }^{13} \mathrm{C}-\mathrm{NMR}, \mathrm{APT}\right)$ and at $282 \mathrm{MHz}\left({ }^{19} \mathrm{~F}-\mathrm{NMR}\right)$ respectively, on Bruker Avance III HD 400 and 500, or Varian Mercury 300, Inova 500 and 600 instruments. Chemical shifts are reported as $\delta$-values in ppm relative to the residual proton peak of the deuterated solvent or its carbon atom, respectively. ${ }^{[166]}$

$\begin{array}{lrc} & { }^{1} \mathrm{H}-\mathrm{NMR} & { }^{13} \mathrm{C}-\mathrm{NMR} \\ \mathrm{CDCl}_{3} & 7.26 \mathrm{ppm} & 77.16 \pm 0.06 \mathrm{ppm} \\ \mathrm{DMSO}^{-\mathrm{d}_{6}} & 2.50 \mathrm{ppm} & 39.52 \pm 0.06 \mathrm{ppm}\end{array}$

For the characterization of the observed signal multiplicities, the following abbreviations were used: s (singlet), d (doublet), t (triplet), q (quartet), hept (heptet), m (multiplet). Coupling constants $J$ are reported in Hertz $(\mathrm{Hz})$.

\subsubsection{Infrared Spectroscopy}

Infrared spectra were recorded using a Bruker Alpha-P ATR FT-IR spectrometer. Liquid samples were measured as a film, and solid samples were measured neat. The analysis of the spectra was carried out using the software from Bruker OPUS 6. The absorption is given in wave numbers $\left(\mathrm{cm}^{-1}\right)$ and the spectra were recorded in the range of $4000-400 \mathrm{~cm}^{-1}$. 


\subsubsection{Mass Spectrometry}

EI- and EI-HRMS spectra were measured on a Time-of-Flight mass spectrometer AccuTOF from Joel. ESI-mass spectra were recorded on an Ion-Trap mass spectrometer $L C Q$ from Finnigan or on a Time-of-Flight mass spectrometer microTOF from Bruker. ESI-HRMS spectra were recorded on a Bruker APEX IV or a Bruker Daltonic (7T, Fourier-Transform Ion Cyclotron Resonance (FTICR)) mass spectrometer. The ratio of mass to charge are indicated, intensities relative to the base peak $(I=100)$ are given in parentheses.

\subsubsection{Reagents}

Chemicals obtained from commercial sources (purity > 95\%) were used without further purification.

The following compounds were synthesized according to known literature procedures: $\left[\left\{\mathrm{RuCl}_{2}(p \text {-cymene })\right\}_{2}\right]$ and $\left[\mathrm{Ru}\left(\mathrm{O}_{2} \mathrm{CMes}\right)_{2}(p\right.$-cymene $\left.)\right]$ by the courtesy of Karsten Rauch. [RuCl(O-Val-Piv)(p-cymene)] by the courtesy of M. Sc. Svenja Warratz.

Potassium phenyltrifluoroborate (77a), potassium $p$-tolyltrifluoroborate (77b) and potassium p-methoxyphenyltrifluoroborate (77d) by the courtesy of B.Sc. Valentin Müller.

Anilides 30 were synthesized according to a previously described procedure. ${ }^{[167]}$

Azoarenes 13 were synthesized according to previously described procedures. ${ }^{[168,169]}$
(E)-1,2-Di-o-tolyldiazene
(13c),
(E)-1,2-di- $p$-tolyldiazene
(13d),
(E)-1,2-bis(3ethylphenyl)diazene (13e), (E)-1,2-bis(3-isopropylphenyl)diazene (13f) and dimethyl 3,3'(diazene-1,2-diyl)(E)-dibenzoate (13k) by the courtesy of B. Sc. Valentin Müller.

5-Aryl-1H-tetrazoles $\mathbf{6 8}$ were synthesized according to a previously described procedure. ${ }^{[122]}$ 1-Benzyl-5-(naphthalen-2-yl)-1H-tetrazole (68g) by the courtesy of Dr. Emelyne Diers. 


\subsection{General Procedures}

\subsubsection{General Procedure A: Ruthenium(II)-catalyzed C-H-arylation of anilides $\mathbf{3 0}$ with boronic acids 73}

In a $20 \mathrm{~mL}$ pre-dried screw-capped sealed tube, a suspension of anilide $\mathbf{3 0}$ (1.0 mmol, 1.0 equiv), [ $\left\{\mathrm{RuCl}_{2}(p \text {-cymene) }\}_{2}\right]$ (30.6 mg, $\left.5.0 \mathrm{~mol} \%\right), \mathrm{AgSbF}_{6}(68.7 \mathrm{mg}, 20 \mathrm{~mol} \%), \mathrm{Ag}_{2} \mathrm{O}$ (232 mg, 1.0 equiv), $\mathrm{Cu}(\mathrm{OTf})_{2}(72.3 \mathrm{mg}, 20 \mathrm{~mol} \%)$ and boronic acid 73 (1.5 mmol, 1.5 equiv) in dry DMF (3.0 mL) was stirred at $110{ }^{\circ} \mathrm{C}$ for $20 \mathrm{~h}$ under a $\mathrm{N}_{2}$ atmosphere. At ambient temperature, the reaction mixture was diluted with EtOAc $(75 \mathrm{~mL})$, filtered through a pad of Celite and silica gel, and the solvents were removed in vacuo. The crude product was purified by column chromatography on silica gel ( $n$-hexane/EtOAc), concentrated and dried in vacuo.

\subsubsection{General Procedure B: Ruthenium(II)-catalyzed C-H-arylation of acetanilides 30 with borinic acids 76}

In a $20 \mathrm{~mL}$ pre-dried screw-capped sealed tube, a suspension of acetanilide 30 (1.0 mmol, 1.0 equiv), [ $\left.\left\{\mathrm{RuCl}_{2}(p \text {-cymene })\right\}_{2}\right](30.6 \mathrm{mg}, 5.0 \mathrm{~mol} \%), \mathrm{AgSbF}_{6}(68.7 \mathrm{mg}, 20 \mathrm{~mol} \%), \mathrm{Ag}_{2} \mathrm{O}$ (232 mg, 1.0 equiv), $\mathrm{Cu}(\mathrm{OTf})_{2}(72.3 \mathrm{mg}, 20 \mathrm{~mol} \%)$ and borinic acid 76 (1.5 mmol, 3.0 equiv) in dry DMF $(3.0 \mathrm{~mL})$ was stirred at $110^{\circ} \mathrm{C}$ for $20 \mathrm{~h}$ under a $\mathrm{N}_{2}$ atmosphere. At ambient temperature, the reaction mixture was diluted with EtOAc $(75 \mathrm{~mL})$, filtered through a pad of Celite and silica gel, and the solvents were removed in vacuo. The crude product was purified by column chromatography on silica gel ( $n$-hexane/EtOAc), concentrated and dried in vacuo.

\subsubsection{General Procedure C: Ruthenium(II)-catalyzed C-H-arylation of acetanilides 30 with potassium trifluoroborates 77}

In a $20 \mathrm{~mL}$ pre-dried screw-capped sealed tube, a suspension of acetanilide $\mathbf{3 0}(0.50 \mathrm{mmol}$, 1.0 equiv), [ $\left.\left\{\mathrm{RuCl}_{2}(p \text {-cymene })\right\}_{2}\right](15.3 \mathrm{mg}, 5.0 \mathrm{~mol} \%), \mathrm{AgSbF}_{6}(34.4 \mathrm{mg}, 20 \mathrm{~mol} \%), \mathrm{Ag}_{2} \mathrm{O}$ (116 mg, 1.0 equiv), $\mathrm{Cu}(\mathrm{OTf})_{2}(36.2 \mathrm{mg}, 20 \mathrm{~mol} \%)$ and potassium trifluoroborate 77 (1.5 mmol, 3.0 equiv) in dry DMF $(3.0 \mathrm{~mL})$ was stirred at $110{ }^{\circ} \mathrm{C}$ for $20 \mathrm{~h}$ under a $\mathrm{N}_{2}$ atmosphere. At ambient temperature, the reaction mixture was diluted with EtOAc $(75 \mathrm{~mL})$, filtered through a pad of Celite and silica gel, and the solvents were removed in vacuo. The 
crude product was purified by column chromatography on silica gel ( $n$-hexane/EtOAc), concentrated and dried in vacuo.

\subsubsection{General Procedure D: Ruthenium(II)-catalyzed C-H-arylation of azoarenes 13}

In a $20 \mathrm{~mL}$ pre-dried screw-capped sealed tube, a suspension of azoarene $\mathbf{1 3}$ (1.0 mmol, 2.0 equiv), $\left[\left\{\mathrm{RuCl}_{2}(p \text {-cymene })\right\}_{2}\right](15.3 \mathrm{mg}, 5.0 \mathrm{~mol} \%), \mathrm{MesCO}_{2} \mathrm{H}(24.6 \mathrm{mg}, 30 \mathrm{~mol} \%)$, $\mathrm{K}_{2} \mathrm{CO}_{3}(138 \mathrm{mg}, 1.0 \mathrm{mmol})$ and (hetero)aryl halide 63 (0.50 mmol, 1.0 equiv) in 1,4-dioxane $\left(2.0 \mathrm{~mL}\right.$ ) was stirred at $120{ }^{\circ} \mathrm{C}$ for $18 \mathrm{~h}$ under a $\mathrm{N}_{2}$ atmosphere. At ambient temperature, the reaction mixture was diluted with $\mathrm{CH}_{2} \mathrm{Cl}_{2}(75 \mathrm{~mL})$, filtered through a pad of Celite and silica gel, and the solvents were removed in vacuo. The crude product was purified by column chromatography on silica ( $n$-hexane/ $\mathrm{CH}_{2} \mathrm{Cl}_{2}$ ) or ( $n$-hexane/EtOAc/NEt 3 ), concentrated and dried in vacuo.

\subsubsection{General Procedure E: One-pot synthesis of ortho-arylated anilines 34}

In a $20 \mathrm{~mL}$ pre-dried screw-capped sealed tube, a suspension of azoarene (13a) $(1.0 \mathrm{mmol}$, 2.0 equiv), [ $\left.\left\{\mathrm{RuCl}_{2}(p \text {-cymene })\right\}_{2}\right]$ (15.3 mg, $\left.5.0 \mathrm{~mol} \%\right), \mathrm{MesCO}_{2} \mathrm{H}(24.6 \mathrm{mg}, 30 \mathrm{~mol} \%)$, $\mathrm{K}_{2} \mathrm{CO}_{3}(138 \mathrm{mg}, 1.0 \mathrm{mmol})$ and aryl bromide 52 (0.50 mmol, 1.0 equiv) in 1,4-dioxane $(2.0 \mathrm{~mL})$ was stirred at $120^{\circ} \mathrm{C}$ for $18 \mathrm{~h}$ under a $\mathrm{N}_{2}$ atmosphere. To the reaction mixture $\mathrm{Zn}$ (164 mg, $2.5 \mathrm{mmol})$ and $\mathrm{HCl}(0.4 \mathrm{~mL})$ were added at $23{ }^{\circ} \mathrm{C}$ and stirred for $24 \mathrm{~h}$ at $23{ }^{\circ} \mathrm{C}$ under a $\mathrm{N}_{2}$ atmosphere. The suspension was diluted with EtOAc $(75 \mathrm{~mL})$, filtered through a pad of Celite and silica gel, and the solvents were removed in vacuo. The crude product was purified by column chromatography on silica gel ( $n$-hexane/EtOAc), concentrated and dried in vacuo.

\subsubsection{General Procedure F: Ruthenium(II)-catalyzed C-H arylation of 5-aryl-1H-tetrazoles 68}

In a $20 \mathrm{~mL}$ pre-dried screw-capped sealed tube, a suspension of 5-aryl-1H-tetrazole $\mathbf{6 8}$ (0.30 mmol, 1.0 equiv), [\{ $\mathrm{RuCl}_{2}(p$-cymene $\left.\left.)\right\}_{2}\right]$ (9.2 mg, $\left.5.0 \mathrm{~mol} \%\right)$, Piv-Val-OH (18.1 mg, $30 \mathrm{~mol} \%), \mathrm{K}_{2} \mathrm{CO}_{3}(138 \mathrm{mg}, 0.90 \mathrm{mmol})$ and (hetero)aryl electrophile 72 (0.90 mmol, 3.0 equiv) in 1,4-dioxane $(0.3 \mathrm{~mL})$ was stirred at $140{ }^{\circ} \mathrm{C}$ for $24 \mathrm{~h}$ under a $\mathrm{N}_{2}$ atmosphere. At ambient temperature, the reaction mixture was diluted with EtOAc $(75 \mathrm{~mL})$, filtered through a 
pad of Celite and silica gel, and the solvents were removed in vacuo. The crude product was purified by column chromatography on silica gel ( $n$-hexane/EtOAc) or $\left(\mathrm{CH}_{2} \mathrm{Cl}_{2} / \mathrm{EtOAc}\right)$, concentrated and dried in vacuo.

\subsection{Procedures}

\subsubsection{Procedure G: Kinetic isotope effect (KIE) study of acetanilide (30a) and isotopically labeled acetanilide $\left[D_{5}\right]-30 a$}

Two independent reactions were conducted to determine the intermolecular kinetic isotope effect (KIE) value by comparison of the initial rates. In a $10 \mathrm{~mL}$ schlenk flask, a suspension of acetanilide (30a) $(135 \mathrm{mg}, 1.0 \mathrm{mmol})$ or $\left[\mathrm{D}_{5}\right]-\mathbf{3 0 a}(140 \mathrm{mg}, 1.0 \mathrm{mmol})$ respectively, $\left[\left\{\mathrm{RuCl}_{2}(p \text {-cymene })\right\}_{2}\right](30.6 \mathrm{mg}, 5.0 \mathrm{~mol} \%), \mathrm{AgSbF}_{6}(68.7 \mathrm{mg}, 20 \mathrm{~mol} \%), \mathrm{Ag}_{2} \mathrm{O}(232 \mathrm{mg}$, 1.0 equiv), $\mathrm{Cu}(\mathrm{OTf})_{2}(72.3 \mathrm{mg}, 20 \mathrm{~mol} \%$ ) and phenylboronic acid (73a) (183 mg, 1.5 equiv) in dry DMF $(3.0 \mathrm{~mL})$ was stirred at $110{ }^{\circ} \mathrm{C}$ under a $\mathrm{N}_{2}$ atmosphere. For $60 \mathrm{~min}$, an aliquot $(0.1 \mathrm{~mL})$ was removed by a syringe every $10 \mathrm{~min}$ and directly analyzed by ${ }^{1} \mathrm{H}-\mathrm{NMR}$ to provide the following conversions (Table 24, Figure 7).

Table 24: Intermolecular kinetic isotope effect study by two independent reactions. ${ }^{\text {[a] }}$

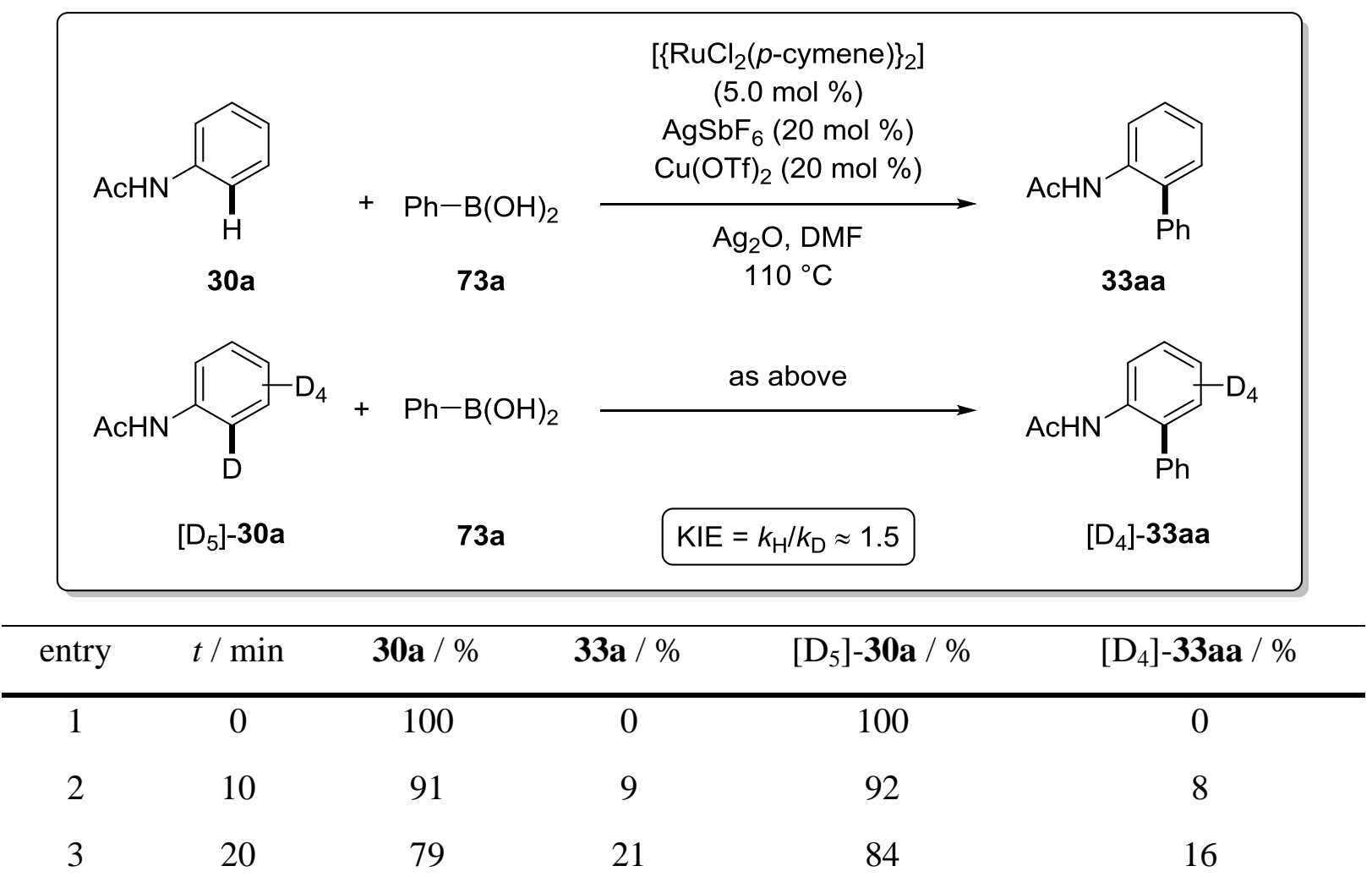




$\begin{array}{llllll}4 & 30 & 70 & 30 & 77 & 23 \\ 5 & 40 & 58 & 42 & 69 & 31 \\ 6 & 50 & 47 & 53 & 63 & 37 \\ 7 & 60 & 38 & 62 & 58 & 42\end{array}$

${ }^{\text {[a] }}$ General reaction conditions: 30a $(1.0 \mathrm{mmol})$ or $\left[\mathrm{D}_{5}\right]-\mathbf{3 0 a}(1.0 \mathrm{mmol}), \mathbf{7 3 a}(1.5 \mathrm{mmol}),\left[\left\{\mathrm{RuCl}_{2}(p \text {-cymene })\right\}_{2}\right]$ (5 mol \%), $\mathrm{AgSbF}_{6}(20 \mathrm{~mol} \%), \mathrm{Cu}(\mathrm{OTf})_{2}(20 \mathrm{~mol} \%), \mathrm{Ag}_{2} \mathrm{O}$ (1.0 equiv), DMF $(3.0 \mathrm{~mL}), 110{ }^{\circ} \mathrm{C}$ for the corresponding time; ${ }^{1} \mathrm{H}-\mathrm{NMR}$ conversions.

The data from two independent reactions are collected in the Table 24 and the intermolecular kinetic isotope effect (KIE) of $k_{\mathrm{H}} / k_{\mathrm{D}} \approx 1.5$ was determined by means of the initial rates exemplified in Figure 7.

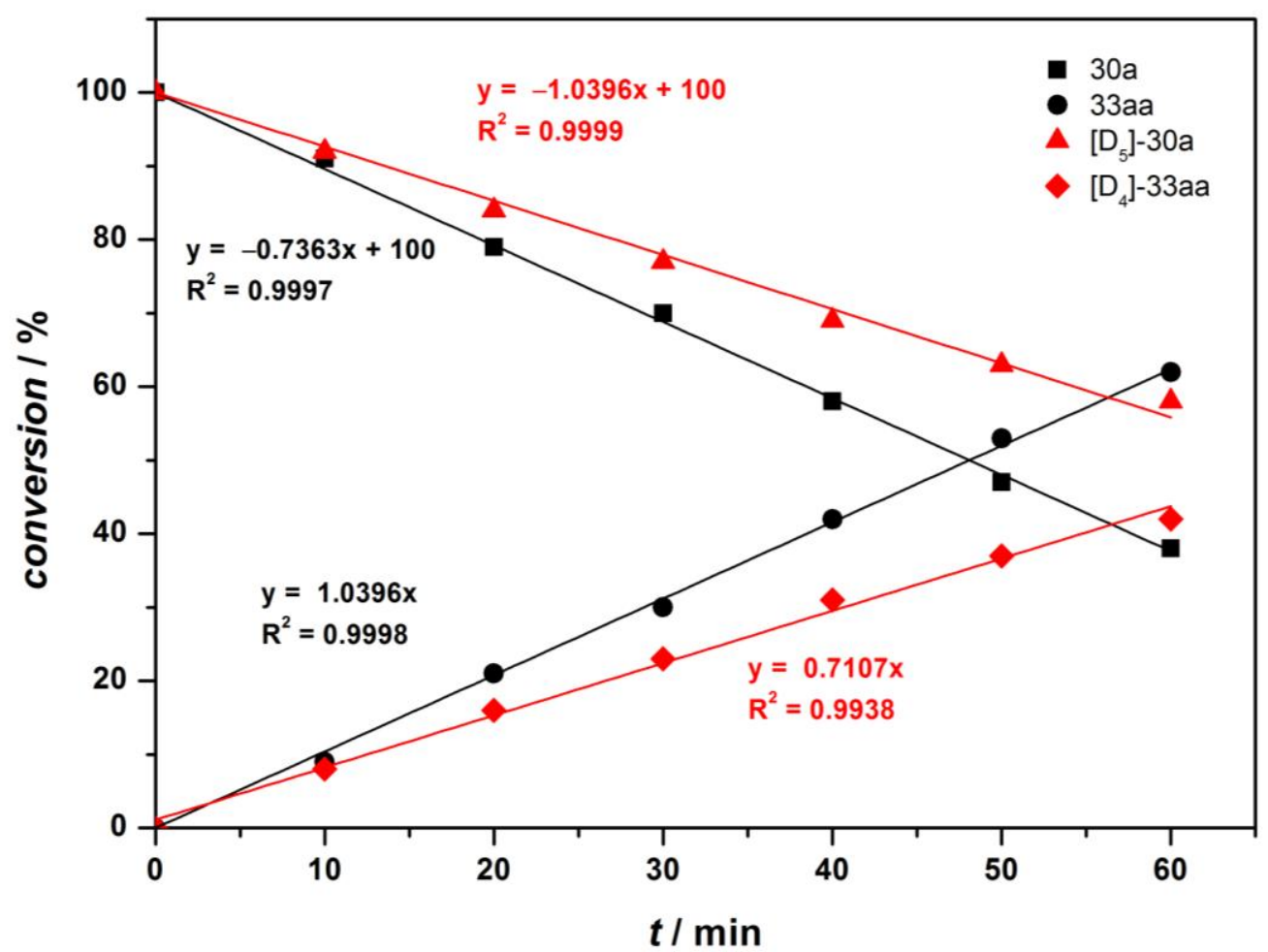

Figure 7: Initial rate data for $\mathrm{C}-\mathrm{H}$ arylation of $\mathbf{3 0 a}$ and $\left[\mathrm{D}_{5}\right]-\mathbf{3 0 a}$. 


\subsubsection{Procedure H: H/D-Exchange experiments of acetanilide 30I}

In a $20 \mathrm{~mL}$ pre-dried screw-capped sealed tube, a suspension of acetanilide 301 (165 mg, $1.0 \mathrm{mmol}),\left[\left\{\mathrm{RuCl}_{2}(p \text {-cymene })\right\}_{2}\right]$ (30.6 mg, $\left.5.0 \mathrm{~mol} \%\right), \mathrm{AgSbF}_{6}(68.7 \mathrm{mg}, 20 \mathrm{~mol} \%), \mathrm{Ag}_{2} \mathrm{O}$ (232 mg, 1.0 equiv) and $\mathrm{Cu}(\mathrm{OTf})_{2}(72.3 \mathrm{mg}, 20 \mathrm{~mol} \%)$ in dry DMF/CD ${ }_{3} \mathrm{OD}(2.7 \mathrm{~mL} / 0.3 \mathrm{~mL})$ was stirred at $110{ }^{\circ} \mathrm{C}$ for $20 \mathrm{~h}$ under a $\mathrm{N}_{2}$ atmosphere. At ambient temperature, the reaction mixture was diluted with EtOAc $(75 \mathrm{~mL})$, filtered through a pad of Celite and silica gel, and the solvents were removed in vacuo. The crude product was purified by column chromatography on silica gel ( $n$-hexane/EtOAc: $1 / 1)$ to yield $\left[\mathrm{D}_{n}\right]-301(164 \mathrm{mg}, 99 \%)$ as a colorless solid. The deuterium incorporation in $\left[\mathrm{D}_{n}\right]-\mathbf{3 0 l}$ was determined by ${ }^{1} \mathrm{H}-\mathrm{NMR}$ spectroscopy (Scheme 26a).

In a $20 \mathrm{~mL}$ pre-dried screw-capped sealed tube, a suspension of acetanilide $\mathbf{3 0 1}$ (165 mg, $1.0 \mathrm{mmol}),\left[\left\{\mathrm{RuCl}_{2}(p \text {-cymene })\right\}_{2}\right]$ (30.6 mg, $\left.5.0 \mathrm{~mol} \%\right), \mathrm{AgSbF}_{6}(68.7 \mathrm{mg}, 20 \mathrm{~mol} \%), \mathrm{Ag}_{2} \mathrm{O}$ (232 mg, 1.0 equiv), $\mathrm{Cu}(\mathrm{OTf})_{2}(72.3 \mathrm{mg}, 20 \mathrm{~mol} \%)$ and phenylboronic acid (73a) (183 $\mathrm{mg}$, 1.5 equiv) in dry $\mathrm{DMF} / \mathrm{CD}_{3} \mathrm{OD}(2.7 \mathrm{~mL} / 0.3 \mathrm{~mL})$ was stirred at $110{ }^{\circ} \mathrm{C}$ for $20 \mathrm{~h}$ under a $\mathrm{N}_{2}$ atmosphere. At ambient temperature, the reaction mixture was diluted with EtOAc $(75 \mathrm{~mL})$, filtered through a pad of Celite and silica gel, and the solvents were removed in vacuo. The crude product was purified by column chromatography on silica gel ( $n$-hexane/EtOAc: $1 / 1)$ to yield $\left[\mathrm{D}_{n}\right]$-301 $(43 \mathrm{mg}, 26 \%)$ and $\left[\mathrm{D}_{n}\right]$-33la $(174 \mathrm{mg}, 72 \%)$ as colorless solids. The deuterium incorporation in $\left[\mathrm{D}_{n}\right]-301$ and $\left[\mathrm{D}_{n}\right]$-33la were determined by ${ }^{1} \mathrm{H}-\mathrm{NMR}$ spectroscopy (Scheme 26b).

\subsubsection{Procedure I: H/D-Exchange experiments of azoarene 13}

In a $20 \mathrm{~mL}$ pre-dried screw-capped sealed tube, a suspension of (E)-1,2-diphenyldiazene (13b) (182 mg, $1.0 \mathrm{mmol}),\left[\left\{\mathrm{RuCl}_{2}(p \text {-cymene })\right\}_{2}\right](15.3 \mathrm{mg}, 5.0 \mathrm{~mol} \%), \mathrm{MesCO}_{2} \mathrm{H}(24.6 \mathrm{mg}$, $30 \mathrm{~mol} \%)$ and $\mathrm{K}_{2} \mathrm{CO}_{3}(138 \mathrm{mg}, 1.0 \mathrm{mmol})$ in 1,4-dioxane/ $\mathrm{D}_{2} \mathrm{O}(1.8 / 0.2 \mathrm{~mL})$ was stirred at $120{ }^{\circ} \mathrm{C}$ for $18 \mathrm{~h}$ under a $\mathrm{N}_{2}$ atmosphere. At ambient temperature, the reaction mixture was diluted with $\mathrm{CH}_{2} \mathrm{Cl}_{2}(75 \mathrm{~mL})$, filtered through a pad of Celite and silica gel, and the solvents were removed in vacuo. The crude product was purified by column chromatography on silica gel ( $n$-hexane/ $\left.\mathrm{CH}_{2} \mathrm{Cl}_{2}: 7 / 3\right)$ to yield $\left[\mathrm{D}_{n}\right]-\mathbf{1 3 b}(178 \mathrm{mg}, 96 \%)$ as an orange solid. The deuterium incorporation in $\left[\mathrm{D}_{n}\right]-\mathbf{1 3 b}$ was determined by ${ }^{1} \mathrm{H}-\mathrm{NMR}$ spectroscopy (Scheme 30a). 
In a $20 \mathrm{~mL}$ pre-dried screw-capped sealed tube, a suspension of (E)-1,2-di-p-tolyldiazene (13d) $(210 \mathrm{mg}, 1.0 \mathrm{mmol}),\left[\left\{\mathrm{RuCl}_{2}(p \text {-cymene })\right\}_{2}\right](15.3 \mathrm{mg}, 5.0 \mathrm{~mol} \%), \mathrm{MesCO}_{2} \mathrm{H}(24.6 \mathrm{mg}$, $30 \mathrm{~mol} \%), \mathrm{K}_{2} \mathrm{CO}_{3}(138 \mathrm{mg}, 1.0 \mathrm{mmol})$ and methyl 4-bromobenzoate (52a) (108 mg, $0.5 \mathrm{mmol})$ in 1,4 -dioxane $/ \mathrm{D}_{2} \mathrm{O}(1.8 / 0.2 \mathrm{~mL})$ was stirred at $120^{\circ} \mathrm{C}$ for $18 \mathrm{~h}$ under a $\mathrm{N}_{2}$ atmosphere. At ambient temperature, the reaction mixture was diluted with $\mathrm{CH}_{2} \mathrm{Cl}_{2}(75 \mathrm{~mL})$, filtered through a pad of Celite and silica gel, and the solvents were removed in vacuo. The crude product was purified by column chromatography on silica gel ( $n$-hexane/ $\mathrm{CH}_{2} \mathrm{Cl}_{2}: 7 / 3$ ) to yield $\left[\mathrm{D}_{n}\right]-\mathbf{1 3 d}(75 \mathrm{mg}, 35 \%)$ and $\left[\mathrm{D}_{n}\right]-\mathbf{8 3 d a}(109 \mathrm{mg}, 63 \%)$ as orange solids. The deuterium incorporation in $\left[\mathrm{D}_{n}\right]-\mathbf{- 1 3 d}$ and $\left[\mathrm{D}_{n}\right]-\mathbf{8 3 d a}$ were determined by ${ }^{1} \mathrm{H}-\mathrm{NMR}$ spectroscopy (Scheme 30b).

\subsubsection{Procedure J: Experiments with radical scavengers for azoarene 13f}

In a $20 \mathrm{~mL}$ pre-dried screw-capped sealed tube, a suspension of azoarene $\mathbf{1 3 f}$ (266 mg, $1.0 \mathrm{mmol}),\left[\left\{\mathrm{RuCl}_{2}(p \text {-cymene })\right\}_{2}\right](15.3 \mathrm{mg}, 5.0 \mathrm{~mol} \%), \mathrm{MesCO}_{2} \mathrm{H}(24.6 \mathrm{mg}, 30 \mathrm{~mol} \%)$, $\mathrm{K}_{2} \mathrm{CO}_{3}(138 \mathrm{mg}, 1.0 \mathrm{mmol})$, methyl 4-bromobenzoate (52a) (108 $\left.\mathrm{mg}, 0.5 \mathrm{mmol}\right)$ and a radical scavenger (1.0 equiv) in 1,4-dioxane $(2.0 \mathrm{~mL})$ was stirred at $120{ }^{\circ} \mathrm{C}$ for $18 \mathrm{~h}$ under a $\mathrm{N}_{2}$ atmosphere. At ambient temperature, the reaction mixture was diluted with $\mathrm{CH}_{2} \mathrm{Cl}_{2}(75 \mathrm{~mL})$, filtered through a pad of Celite and silica gel, and the solvents were removed in vacuo. The crude product was purified by column chromatography on silica ( $n$-hexane/ $\mathrm{CH}_{2} \mathrm{Cl}_{2}: 7 / 3$ ) providing the following yields of $\mathbf{8 3 f a}$ as an orange solid (Table 15).

\subsubsection{Procedure K: Hammett plot analysis}

In a $20 \mathrm{~mL}$ pre-dried screw-capped sealed tube, a suspension of (E)-1,2-di-m-tolyldiazene (13a) $(210 \mathrm{mg}, 1.0 \mathrm{mmol}),\left[\left\{\mathrm{RuCl}_{2}(p \text {-cymene })\right\}_{2}\right]$ (15.3 mg, $\left.5.0 \mathrm{~mol} \%\right), \mathrm{MesCO}_{2} \mathrm{H}(24.6 \mathrm{mg}$, $30 \mathrm{~mol} \%), \mathrm{K}_{2} \mathrm{CO}_{3}(138 \mathrm{mg}, 1.0 \mathrm{mmol})$ and para-substituted aryl bromide 52 (0.5 mmol) in 1,4-dioxane $(3.0 \mathrm{~mL})$ was stirred at $120^{\circ} \mathrm{C}$ under a $\mathrm{N}_{2}$ atmosphere. For the indicated interval, an aliquot $(0.1 \mathrm{~mL})$ was removed by a syringe and directly analyzed by GC of the desired product 37 using $n$-dodecane as internal standard (Table 25, Figures 3 and 4). 
Table 25: Hammett plot study of azoarene 13a with para-substituded aryl bromides 52. ${ }^{[a]}$<smiles>Cc1cccc(/N=N/c2cccc(C)c2)c1</smiles>

$13 a$<smiles>[R]c1ccc(Br)cc1</smiles>

52

$$
\begin{gathered}
{\left[\left\{\mathrm{RuCl}_{2}(p \text {-cymene })\right\}_{2}\right]} \\
(5.0 \mathrm{~mol} \%) \\
\mathrm{MesCO}_{2} \mathrm{H}(30 \mathrm{~mol} \%)
\end{gathered}
$$<smiles>[R]c1ccc(-c2ccc(C)cc2N=Nc2cccc(C)c2)cc1</smiles>

83

\begin{tabular}{ccccc}
\hline entry & $\mathrm{R}$ & $\sigma_{\mathrm{p}}$ & initial rate & $\log \left(k_{\mathrm{X}} / k_{\mathrm{H}}\right)$ \\
\hline 1 & $\mathrm{~N}(\mathrm{Me})_{2}$ & -0.83 & 0.19785 & 0.159 \\
2 & $\mathrm{OMe}$ & -0.27 & 0.16019 & 0.068 \\
3 & $\mathrm{H}$ & 0 & 0.13705 & 0 \\
4 & $\mathrm{Cl}$ & 0.23 & 0.12183 & -0.051 \\
5 & $\mathrm{CO}_{2} \mathrm{Me}$ & 0.45 & 0.10869 & -0.101 \\
6 & $\mathrm{C}(\mathrm{O}) \mathrm{Me}$ & 0.50 & 0.105 & -0.116 \\
\hline
\end{tabular}

${ }^{[a]}$ General reaction conditions: 13a $(1.0 \mathrm{mmol}), 52(0.5 \mathrm{mmol}),\left[\left\{\mathrm{RuCl}_{2}(p \text {-cymene })\right\}_{2}\right](5.0 \mathrm{~mol} \%), \mathrm{MesCO}_{2} \mathrm{H}$ (30 mol \%), $\mathrm{K}_{2} \mathrm{CO}_{3}(1.0 \mathrm{mmol}), 1,4$-dioxane $(3.0 \mathrm{~mL}), 120^{\circ} \mathrm{C}, 18 \mathrm{~h}$; $\mathrm{GC}$ yields.

\subsubsection{Procedure L: Experiments with radical scavengers for tetrazole 68a}

In a $20 \mathrm{~mL}$ pre-dried screw-capped sealed tube, a suspension of 1-benzyl-5-phenyl-1Htetrazole $\quad(\mathbf{6 8 a}) \quad(70.9 \mathrm{mg}, \quad 0.30 \mathrm{mmol}), \quad\left[\left\{\mathrm{RuCl}_{2}(p \text {-cymene })\right\}_{2}\right] \quad(9.2 \mathrm{mg}, \quad 5.0 \mathrm{~mol} \%)$, Piv-Val-OH (18.1 mg, $30 \mathrm{~mol} \%), \mathrm{K}_{2} \mathrm{CO}_{3}(124 \mathrm{mg}, 0.90 \mathrm{mmol})$, methyl 4-chlorobenzoate (59a) $(154 \mathrm{mg}, 0.90 \mathrm{mmol})$ and a radical scavenger (1.0 equiv) in 1,4-dioxane $(0.3 \mathrm{~mL})$ was stirred at $140{ }^{\circ} \mathrm{C}$ for $24 \mathrm{~h}$ under a $\mathrm{N}_{2}$ atmosphere. At ambient temperature, the reaction mixture was diluted with EtOAc $(75 \mathrm{~mL})$, filtered through a pad of Celite and silica gel, and the solvents were removed in vacuo. The crude product was purified by column chromatography on silica ( $n$-hexane/EtOAc: $4 / 1)$ yielded 69aa $(86 \mathrm{mg}, 77 \%)$ as colorless solid (Table 23). 


\subsubsection{Procedure M: Initial rate acceleration of formation of tetrazole 69aa enabled by pre-ligand}

Three different reaction conditions were investigated: [a] with $\mathrm{MesCO}_{2} \mathrm{H}$, [b] with Piv-Val-OH and [c] without additive. Five seperate reactions were conducted simultaneously for each reaction condition. In a $20 \mathrm{~mL}$ pre-dried screw-capped sealed tube, a suspension of 1-benzyl-5-phenyl-1H-tetrazole (68a) $(70.9 \mathrm{mg}, 0.30 \mathrm{mmol}),\left[\left\{\mathrm{RuCl}_{2}(p \text {-cymene })\right\}_{2}\right](9.2 \mathrm{mg}$, $5.0 \mathrm{~mol} \%), \quad \mathrm{MesCO}_{2} \mathrm{H}(14.8 \mathrm{mg}, 30 \mathrm{~mol} \%), \mathrm{K}_{2} \mathrm{CO}_{3}(124 \mathrm{mg}, 0.90 \mathrm{mmol})$ and methyl 4-chlorobenzoate (59a) $(154 \mathrm{mg}, 0.90 \mathrm{mmol})$ in 1,4-dioxane $(0.3 \mathrm{~mL})$ was stirred at $140{ }^{\circ} \mathrm{C}$ for the corresponding time. Upon completion, the sealed tube was quickly cooled down in an ice bath. The reaction mixture was diluted with EtOAc $(75 \mathrm{~mL})$, filtered through a pad of Celite and silica gel, and the solvents were removed in vacuo. Subsequently, $\mathrm{CH}_{2} \mathrm{Br}_{2}(21 \mu \mathrm{L}$, $0.30 \mathrm{mmol}$ ) was added as internal standard in $\mathrm{CDCl}_{3}$ and directly analyzed by ${ }^{1} \mathrm{H}-\mathrm{NMR}$ to provide the following yields (Table 26, Figure 5).

Table 26: Initial rate comparison for the $\mathrm{C}-\mathrm{H}$ arylation with and without additives. ${ }^{\text {[a] }}$

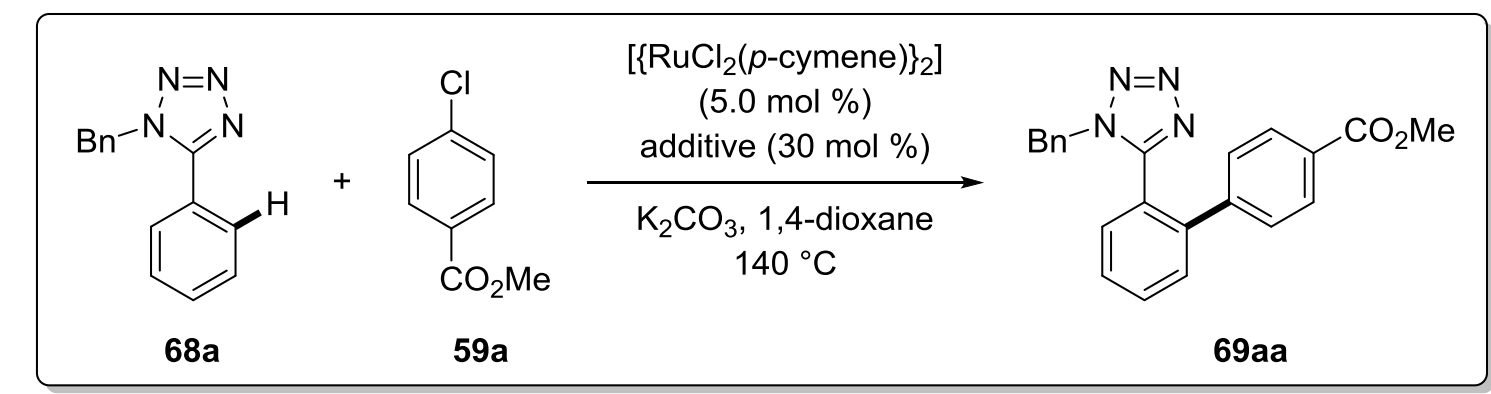

\begin{tabular}{ccccc}
\hline entry & $t /$ min & $\mathbf{6 9 a a}^{[\mathrm{a}]} / \%$ & $\mathbf{6 9 a a}^{[\mathrm{b}]} / \%$ & $\mathbf{6 9 a a}^{[\mathrm{c}]} / \%$ \\
\hline 1 & 0 & 0 & 0 & 0 \\
2 & 60 & 14 & 12 & 4 \\
3 & 120 & 25 & 23 & 9 \\
4 & 180 & 38 & 34 & 14 \\
5 & 240 & 52 & 43 & 20 \\
6 & 300 & 64 & 53 & 24 \\
\hline
\end{tabular}

${ }^{[a]}$ General reaction conditions: $68 \mathbf{a}(0.30 \mathrm{mmol}), \quad 59 a \quad(0.90 \mathrm{mmol}), \quad\left[\left\{\mathrm{RuCl}_{2}(p \text {-cymene })\right\}_{2}\right] \quad(5.0 \mathrm{~mol} \%)$, $\mathrm{MesCO}_{2} \mathrm{H}(14.8 \mathrm{mg}, 30 \mathrm{~mol} \%), \mathrm{K}_{2} \mathrm{CO}_{3}(0.90 \mathrm{mmol}), 1$,4-dioxane $(0.3 \mathrm{~mL}), 140{ }^{\circ} \mathrm{C}$ for the corresponding time; yields were determined by ${ }^{1} \mathrm{H}-\mathrm{NMR}$ using $\mathrm{CH}_{2} \mathrm{Br}_{2}(21 \mu \mathrm{L}, 0.30 \mathrm{mmol})$ as internal standard. ${ }^{[\mathrm{b}]} \mathrm{Piv}-\mathrm{Val}-\mathrm{OH}$ (18.1 mg, $30 \mathrm{~mol} \%) .{ }^{\text {[c] }}$ without additive. 


\subsubsection{Procedure N: Kinetic reaction profile of formation of tetrazole 69aa}

Two different reaction conditions were investigated: [a] with $\mathrm{MesCO}_{2} \mathrm{H}$ and [b] with Piv-Val$\mathrm{OH}$. Eleven seperate reactions were conducted simultaneously for each reaction condition. In a $20 \mathrm{~mL}$ pre-dried screw-capped sealed tube, a suspension of 1-benzyl-5-phenyl-1 $H$-tetrazole (68a) $\quad(70.9 \mathrm{mg}, \quad 0.30 \mathrm{mmol}), \quad\left[\left\{\mathrm{RuCl}_{2}(p \text {-cymene })\right\}_{2}\right] \quad(9.2 \mathrm{mg}, \quad 5.0 \mathrm{~mol} \%), \quad \mathrm{MesCO}_{2} \mathrm{H}$ (14.8 $\mathrm{mg}, 30 \mathrm{~mol} \%), \mathrm{K}_{2} \mathrm{CO}_{3}(124 \mathrm{mg}, 0.90 \mathrm{mmol})$ and methyl 4-chlorobenzoate (59a) (154 mg, $0.90 \mathrm{mmol})$ in 1,4-dioxane $(0.3 \mathrm{~mL})$ was stirred at $140{ }^{\circ} \mathrm{C}$ for the corresponding time. Upon completion, the sealed tube was quickly cooled down in an ice bath. The reaction mixture was diluted with EtOAc $(75 \mathrm{~mL})$, filtered through a pad of Celite and silica gel, and the solvents were removed in vacuo. Subsequently, $\mathrm{CH}_{2} \mathrm{Br}_{2}(21 \mu \mathrm{L}, 0.30 \mathrm{mmol})$ was added as internal standard in $\mathrm{CDCl}_{3}$ and directly analyzed by ${ }^{1} \mathrm{H}-\mathrm{NMR}$ to provide the following yields (Table 27, Figure 6).

Table 27: Kinetic reaction profile for the $\mathrm{C}-\mathrm{H}$ arylation of tetrazole $\mathbf{6 8 a}$ exerted by additives. ${ }^{\text {[a] }}$

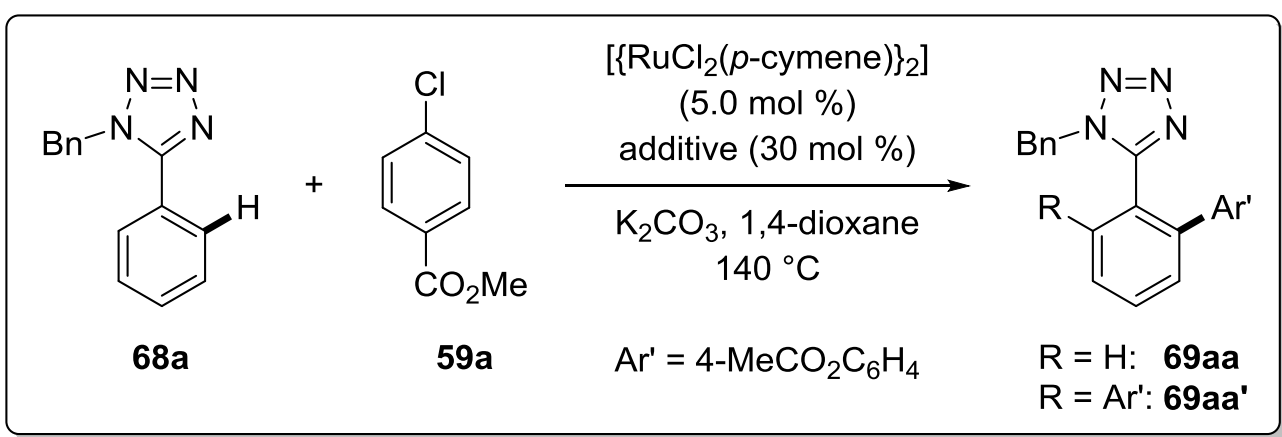

\begin{tabular}{cccccc}
\hline entry & $t / \mathbf{h}$ & $\mathbf{6 9 a a}^{[\mathrm{a}]} / \%$ & $\mathbf{6 9}^{\mathbf{a}^{[\mathrm{a}]} / \%}$ & $\mathbf{6 9 a a}^{[\mathrm{b}]} / \%$ & $\mathbf{6 9 a a}^{\mathbf{}^{[\mathrm{b}]} / \%}$ \\
\hline 1 & 0 & 0 & 0 & 0 & 0 \\
2 & 1 & 14 & 0 & 12 & 0 \\
3 & 2 & 25 & 0 & 23 & 0 \\
4 & 3 & 38 & 0 & 34 & 0 \\
5 & 4 & 52 & 0 & 43 & 0 \\
6 & 5 & 64 & 0 & 53 & 0 \\
7 & 7 & 66 & 1 & 63 & 2 \\
8 & 9 & 67 & 3 & 68 & 4 \\
9 & 14 & 70 & 6 & 76 & 8 \\
10 & 17 & 71 & 8 & 78 & 10
\end{tabular}




$\begin{array}{llllll}11 & 20 & 72 & 10 & 80 & 12 \\ 12 & 24 & 72 & 12 & 82 & 14\end{array}$

${ }^{[a]}$ General reaction conditions: 68a $(0.30 \mathrm{mmol}), \mathbf{5 9 a}(0.90 \mathrm{mmol}),\left[\left\{\mathrm{RuCl}_{2}(p \text {-cymene })\right\}_{2}\right] \quad(5.0 \mathrm{~mol} \%)$, $\mathrm{MesCO}_{2} \mathrm{H}(14.8 \mathrm{mg}, 30 \mathrm{~mol} \%), \mathrm{K}_{2} \mathrm{CO}_{3}(0.90 \mathrm{mmol}), 1,4$-dioxane $(0.3 \mathrm{~mL}), 140{ }^{\circ} \mathrm{C}$ for the corresponding time; yields were determined by ${ }^{1} \mathrm{H}-\mathrm{NMR}$ using $\mathrm{CH}_{2} \mathrm{Br}_{2}(21 \mu \mathrm{L}, 0.30 \mathrm{mmol})$ as internal standard. ${ }^{[b]} \mathrm{Piv}-\mathrm{Val}-\mathrm{OH}$ (18.1 mg, $30 \mathrm{~mol} \%)$. 


\section{Analytical Data}

\section{Synthesis of $N$-([1,1'-Biphenyl]-2-yl)acetamide (33aa)}

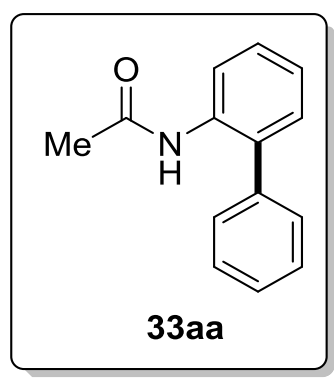

The general procedure A was followed using 30a (135 mg, $1.00 \mathrm{mmol})$ and phenylboronic acid (73a) (183 mg, $1.50 \mathrm{mmol})$. Purification by column chromatography ( $n$-hexane/EtOAc: 7/3) yielded 33aa (162 mg, 77\%) as a colorless solid.

The general procedure B was followed using $\mathbf{3 0 a}(135 \mathrm{mg}, 1.00 \mathrm{mmol})$ and hydroxydiphenylborane (76a) (273 mg, $1.50 \mathrm{mmol}$ ). Purification by column chromatography ( $n$-hexane/EtOAc: $7 / 3$ ) yielded 33aa (137 $\mathrm{mg}, 65 \%)$ as a colorless solid.

The general procedure $\mathbf{C}$ was followed using 30a $(67.6 \mathrm{mg}, 0.50 \mathrm{mmol})$ and potassium phenyltrifluoroborate (77a) $(276 \mathrm{mg}, 1.50 \mathrm{mmol})$. Purification by column chromatography (n-hexane/EtOAc: $7 / 3$ ) yielded 33aa (55 mg, 52\%) as a colorless solid.

M. p.: $113-115^{\circ} \mathrm{C}$.

${ }^{\mathbf{1}} \mathbf{H}$-NMR $\left(300 \mathrm{MHz}, \mathrm{CDCl}_{3}\right): \delta=8.21(\mathrm{~d}, J=8.2 \mathrm{~Hz}, 1 \mathrm{H}), 7.51-7.30(\mathrm{~m}, 6 \mathrm{H}), 7.24-7.13(\mathrm{~m}$, 3H), 1.98 (s, 3H).

${ }^{13}$ C-NMR $\left(126 \mathrm{MHz}, \mathrm{CDCl}_{3}\right): \delta=168.2\left(\mathrm{C}_{\mathrm{q}}\right), 138.1\left(\mathrm{C}_{\mathrm{q}}\right), 134.6\left(\mathrm{C}_{\mathrm{q}}\right), 132.2\left(\mathrm{C}_{\mathrm{q}}\right), 130.0(\mathrm{CH})$, $129.1(\mathrm{CH}), 129.0(\mathrm{CH}), 128.2(\mathrm{CH}), 127.9(\mathrm{CH}), 124.3(\mathrm{CH}), 121.7(\mathrm{CH}), 24.4\left(\mathrm{CH}_{3}\right)$.

IR (ATR): 3284, 3230, 3054, 3027, 1658, 1531, 1433, 1301, 755, $662 \mathrm{~cm}^{-1}$.

MS (EI) $m / z$ (relative intensity): $211\left(\left[\mathrm{M}^{+}\right]\right.$34), 169 (100), 139 (7), 115 (5), 43 (15). 
HR-MS (EI) $m / z$ for $\mathrm{C}_{14} \mathrm{H}_{13} \mathrm{NO}\left[\mathrm{M}^{+}\right]$

calcd.: 211.0997.

found: 211.0996 .

The analytical data are in accordance with those reported in the literature. ${ }^{[163 b]}$

Synthesis of $N$-([1,1'-Biphenyl]-2-yl)isobutyramide (33ba)

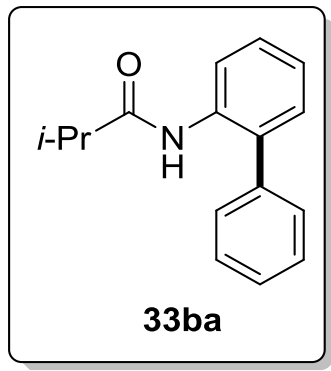

The general procedure A was followed using $30 \mathrm{~b}(163 \mathrm{mg}, 1.00 \mathrm{mmol})$ and phenylboronic acid (73a) (183 mg, $1.50 \mathrm{mmol})$. Purification by column chromatography ( $n$-hexane/EtOAc: $7 / 3$ ) yielded $\mathbf{3 3 b a}(132 \mathrm{mg}, 55 \%)$ as a colorless solid.

M. p.: $126-128^{\circ} \mathrm{C}$.

${ }^{1} \mathbf{H}-\mathbf{N M R}\left(300 \mathrm{MHz}, \mathrm{CDCl}_{3}\right): \delta=8.33(\mathrm{~d}, J=8.2 \mathrm{~Hz}, 1 \mathrm{H}), 7.54-7.33(\mathrm{~m}, 6 \mathrm{H}), 7.28-7.13(\mathrm{~m}$, $3 \mathrm{H}), 2.4$ (hept, $J=6.8 \mathrm{~Hz}, 1 \mathrm{H}), 1.2(\mathrm{~d}, J=6.8 \mathrm{~Hz}, 6 \mathrm{H})$.

${ }^{13}$ C-NMR $\left(126 \mathrm{MHz}, \mathrm{CDCl}_{3}\right): \delta=174.8\left(\mathrm{C}_{\mathrm{q}}\right), 138.1\left(\mathrm{C}_{\mathrm{q}}\right), 134.9\left(\mathrm{C}_{\mathrm{q}}\right), 132.1\left(\mathrm{C}_{\mathrm{q}}\right), 129.9(\mathrm{CH})$, $129.3(\mathrm{CH}), 129.0(\mathrm{CH}), 128.4(\mathrm{CH}), 128.0(\mathrm{CH}), 124.0(\mathrm{CH}), 121.3(\mathrm{CH}), 36.7(\mathrm{CH}), 19.3$ $\left(\mathrm{CH}_{3}\right)$.

IR (ATR): 3218, 2964, 1649, 1520, 1480, 1239, 1203, 1099, 776, $542 \mathrm{~cm}^{-1}$.

MS (EI) $m / z$ (relative intensity): 239 ([M+ $\left.\left.{ }^{+}\right] 29\right), 169$ (100), 71 (6), 43 (30).

HR-MS (EI) $m / z$ for $\mathrm{C}_{16} \mathrm{H}_{17} \mathrm{NO}\left[\mathrm{M}^{+}\right] \quad$ calcd.: 239.1310 .

found: 239.1314 . 


\section{Synthesis of $N$-([1,1'-Biphenyl]-2-yl)pivalamide (33ca)}

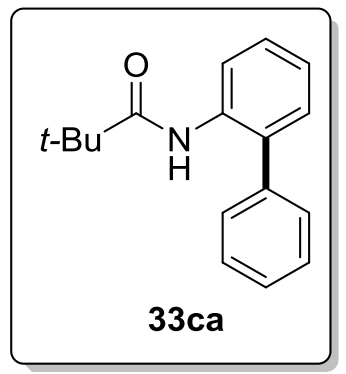

The general procedure A was followed using 30c $(177 \mathrm{mg}, 1.00 \mathrm{mmol})$ and phenylboronic acid (73a) (183 mg, $1.50 \mathrm{mmol})$. Purification by column chromatography (n-hexane/EtOAc: $7 / 3$ ) yielded 33ca (114 mg, 45\%) as a colorless solid.

M. p.: $68-69^{\circ} \mathrm{C}$.

${ }^{1} \mathbf{H}-\mathbf{N M R}\left(300 \mathrm{MHz}, \mathrm{CDCl}_{3}\right): \delta=8.37(\mathrm{dd}, J=8.2,1.2 \mathrm{~Hz}, 1 \mathrm{H}), 7.54-7.33(\mathrm{~m}, 7 \mathrm{H}), 7.24(\mathrm{dd}$, $J=7.4,1.7 \mathrm{~Hz}, 1 \mathrm{H}), 7.17(\mathrm{dd}, J=7.4,1.7 \mathrm{~Hz}, 1 \mathrm{H}), 1.09(\mathrm{~s}, 9 \mathrm{H})$.

${ }^{13}$ C-NMR $\left(126 \mathrm{MHz}, \mathrm{CDCl}_{3}\right): \delta=176.1\left(\mathrm{C}_{\mathrm{q}}\right), 138.0\left(\mathrm{C}_{\mathrm{q}}\right), 135.0\left(\mathrm{C}_{\mathrm{q}}\right), 132.0\left(\mathrm{C}_{\mathrm{q}}\right), 129.6(\mathrm{CH})$, $129.2(\mathrm{CH}), 128.9(\mathrm{CH}), 128.4(\mathrm{CH}), 127.9(\mathrm{CH}), 123.8(\mathrm{CH}), 120.8(\mathrm{CH}), 39.8\left(\mathrm{C}_{\mathrm{q}}\right), 27.4$ $\left(\mathrm{CH}_{3}\right)$.

IR (ATR): 3259, 3056, 2970, 2904, 2868, 1646, 1503, 1477, 771, $647 \mathrm{~cm}^{-1}$.

MS (EI) $m / z$ (relative intensity): 253 ([M+ $\left.{ }^{+}\right]$53), 169 (60), 57 (100), 41 (17).

HR-MS (EI) $m / z$ for $\mathrm{C}_{17} \mathrm{H}_{19} \mathrm{NO}\left[\mathrm{M}^{+}\right]$

calcd.: 253.1467 .

found: 253.1472 .

The analytical data are in accordance with those reported in the literature. ${ }^{[170]}$ 


\section{Synthesis of $N$-([1,1'-Biphenyl]-2-yl)-2,6-difluorobenzamide (33da)}

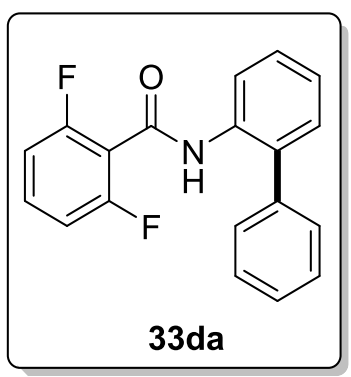

The general procedure A was followed using 30d $(233 \mathrm{mg}, 1.00 \mathrm{mmol})$ and phenylboronic acid (73a) (183 mg, $1.50 \mathrm{mmol})$. Purification by column chromatography ( $n$-hexane/EtOAc: 7/3) yielded 33da (93 mg, 30\%) as a colorless solid.

M. p.: $127-128^{\circ} \mathrm{C}$.

${ }^{1} \mathbf{H}-\mathbf{N M R}\left(300 \mathrm{MHz}, \mathrm{CDCl}_{3}\right): \delta=8.48(\mathrm{~d}, J=8.0 \mathrm{~Hz}, 1 \mathrm{H}), 7.61(\mathrm{~s}, 1 \mathrm{H}), 7.50-7.17(\mathrm{~m}, 9 \mathrm{H})$, $6.90(\mathrm{t}, J=8.2 \mathrm{~Hz}, 2 \mathrm{H})$.

${ }^{13}$ C-NMR $\left(126 \mathrm{MHz}, \mathrm{CDCl}_{3}\right): \delta=159.8\left(\mathrm{C}_{\mathrm{q}}, J_{\mathrm{C}-\mathrm{F}}=246.4,6.7 \mathrm{~Hz}\right), 158.2\left(\mathrm{C}_{\mathrm{q}}\right), 137.5\left(\mathrm{C}_{\mathrm{q}}\right)$, $134.2\left(\mathrm{C}_{\mathrm{q}}\right), 132.5\left(\mathrm{C}_{\mathrm{q}}\right), 131.8\left(\mathrm{CH}, J_{\mathrm{C}-\mathrm{F}}=10.3 \mathrm{~Hz}\right), 130.1(\mathrm{CH}), 129.3(\mathrm{CH}), 128.9(\mathrm{CH})$, $128.4(\mathrm{CH}), 128.0(\mathrm{CH}), 124.9(\mathrm{CH}), 121.7(\mathrm{CH}), 114.4\left(\mathrm{C}_{\mathrm{q}}, J_{\mathrm{C}-\mathrm{F}}=19.6 \mathrm{~Hz}\right), 112.0(\mathrm{CH}$, $\left.J_{\mathrm{C}-\mathrm{F}}=20.5,4.4 \mathrm{~Hz}\right)$.

${ }^{19}$ F-NMR $\left(282 \mathrm{MHz}, \mathrm{CDCl}_{3}\right): \delta=-(111.85-112.02)(\mathrm{m})$.

IR (ATR): 3218, 3058, 3031, 1653, 1623, 1516, 1462, 1303, 1005, $741 \mathrm{~cm}^{-1}$.

MS (EI) $m / z$ (relative intensity): 309 ([M+ $[57), 167$ (14), 141 (100), 113 (21), 63 (7).

HR-MS (EI) $m / z$ for $\mathrm{C}_{19} \mathrm{H}_{13} \mathrm{~F}_{2} \mathrm{NO}\left[\mathrm{M}^{+}\right] \quad$ calcd.: 309.0965 . found: 309.0960 . 


\section{Synthesis of $N$-(3-Methyl-[1,1'-biphenyl]-2-yl)acetamide (33ha)}

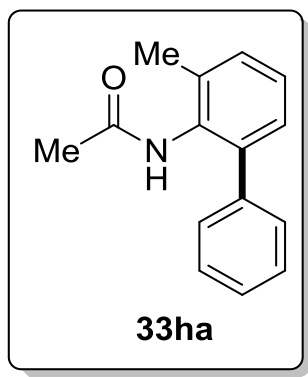

The general procedure A was followed using $\mathbf{3 0 h}(149 \mathrm{mg}, 1.00 \mathrm{mmol})$ and phenylboronic acid (73a) (183 mg, $1.50 \mathrm{mmol})$. Purification by column chromatography ( $n$-hexane/EtOAc: $7 / 3$ ) yielded 33ha (76 mg, 34\%) as a colorless solid.

M. p.: $125-127^{\circ} \mathrm{C}$.

${ }^{1} \mathbf{H}-\mathbf{N M R}\left(300 \mathrm{MHz}, \mathrm{CDCl}_{3}\right): \delta=7.43-7.30(\mathrm{~m}, 5 \mathrm{H}), 7.29-7.24(\mathrm{~m}, 2 \mathrm{H}), 7.21-7.14(\mathrm{~m}, 1 \mathrm{H})$, $6.64(\mathrm{~s}, 1 \mathrm{H}), 2.31(\mathrm{~s}, 3 \mathrm{H}), 2.00(\mathrm{~s}, 3 \mathrm{H})$.

${ }^{13}$ C-NMR $\left(126 \mathrm{MHz}, \mathrm{CDCl}_{3}\right): \delta=169.4\left(\mathrm{C}_{\mathrm{q}}\right), 139.7\left(\mathrm{C}_{\mathrm{q}}\right), 139.6\left(\mathrm{C}_{\mathrm{q}}\right), 136.9\left(\mathrm{C}_{\mathrm{q}}\right), 132.6\left(\mathrm{C}_{\mathrm{q}}\right)$, $130.2(\mathrm{CH}), 128.9(\mathrm{CH}), 128.4(\mathrm{CH}), 127.9(\mathrm{CH}), 127.5(\mathrm{CH}), 127.4(\mathrm{CH}), 23.0\left(\mathrm{CH}_{3}\right), 18.5$ $\left(\mathrm{CH}_{3}\right)$.

IR (ATR): 3269, 3024, 2956, 2922, 1646, 1516, 1463, 1365, 1289, $790 \mathrm{~cm}^{-1}$.

MS (EI) $m / z$ (relative intensity): 225 ([ $\left.\mathrm{M}^{+}\right]$36), 183 (100), 167 (31), 43 (26).

HR-MS (EI) $m / z$ for $\mathrm{C}_{15} \mathrm{H}_{15} \mathrm{NO}\left[\mathrm{M}^{+}\right]$ calcd.: 225.1154 . found: 225.1146 .

The analytical data are in accordance with those reported in the literature. ${ }^{[29]}$ 


\section{Synthesis of $N$-(4-Methyl-[1,1'-biphenyl]-2-yl)acetamide (33ia)}

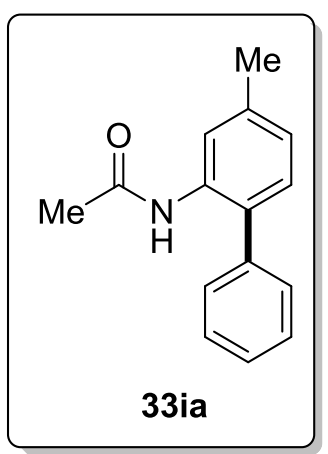

The general procedure A was followed using 30i (149 mg, $1.00 \mathrm{mmol}$ ) and phenylboronic acid (73a) (183 mg, $1.50 \mathrm{mmol})$. Purification by column chromatography ( $n$-hexane/EtOAc: $7 / 3$ ) yielded 33ia (175 mg, 78\%) as a colorless solid.

The general procedure $\mathbf{C}$ was followed using $30 \mathrm{i}(74.6 \mathrm{mg}, 0.50 \mathrm{mmol})$ and potassium phenyltrifluoroborate (77a) (276 mg, $1.50 \mathrm{mmol})$. Purification by column chromatography (n-hexane/EtOAc: $7 / 3$ ) yielded 33ia (61 mg, 54\%) as a colorless solid.

M. p.: $139-141^{\circ} \mathrm{C}$.

${ }^{\mathbf{1}} \mathbf{H}-\mathbf{N M R}\left(300 \mathrm{MHz}, \mathrm{CDCl}_{3}\right): \delta=8.04(\mathrm{~s}, 1 \mathrm{H}), 7.50-7.28(\mathrm{~m}, 5 \mathrm{H}), 7.21-7.08(\mathrm{~m}, 2 \mathrm{H}), 6.98$ $(\mathrm{d}, J=7.6 \mathrm{~Hz}, 1 \mathrm{H}), 2.38(\mathrm{~s}, 3 \mathrm{H}), 1.98(\mathrm{~s}, 3 \mathrm{H})$.

${ }^{13}$ C-NMR $\left(126 \mathrm{MHz}, \mathrm{CDCl}_{3}\right): \delta=168.0\left(\mathrm{C}_{\mathrm{q}}\right), 138.3\left(\mathrm{C}_{\mathrm{q}}\right), 138.1\left(\mathrm{C}_{\mathrm{q}}\right), 134.3\left(\mathrm{C}_{\mathrm{q}}\right), 129.7(\mathrm{CH})$, $129.4\left(\mathrm{C}_{\mathrm{q}}\right), 129.2(\mathrm{CH}), 128.9(\mathrm{CH}), 127.6(\mathrm{CH}), 125.1(\mathrm{CH}), 122.2(\mathrm{CH}), 24.6\left(\mathrm{CH}_{3}\right), 21.5$ $\left(\mathrm{CH}_{3}\right)$.

IR (ATR): 3224, 3029, 2916, 1652, 1539, 1476, 1412, 1297, 820, $763 \mathrm{~cm}^{-1}$.

MS (EI) $m / z$ (relative intensity): 225 ([ $\left.\mathrm{M}^{+}\right]$54), 183 (100), 167 (30), 43 (20).

HR-MS (EI) $m / z$ for $\mathrm{C}_{15} \mathrm{H}_{15} \mathrm{NO}\left[\mathrm{M}^{+}\right]$

calcd.: 225.1154 .

found: 225.1159 . 


\section{Synthesis of $N$-(5-Methyl-[1,1'-biphenyl]-2-yl)acetamide (33ja)}

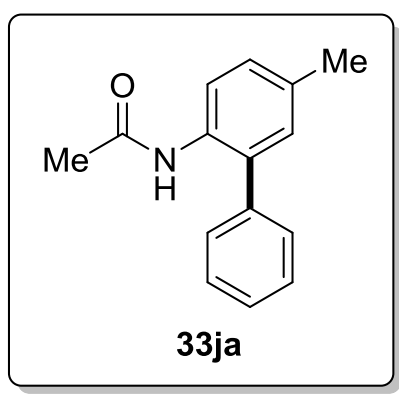

The general procedure A was followed using 30j (149 mg, $1.00 \mathrm{mmol}$ ) and phenylboronic acid (73a) (183 mg, $1.50 \mathrm{mmol})$. Purification by column chromatography (n-hexane/EtOAc: $7 / 3$ ) yielded 33ja (178 $\mathrm{mg}, 79 \%)$ as a colorless solid.

M. p.: $107-109^{\circ} \mathrm{C}$.

${ }^{1} \mathbf{H}$-NMR $\left(300 \mathrm{MHz}, \mathrm{CDCl}_{3}\right): \delta=8.06(\mathrm{~d}, J=8.3 \mathrm{~Hz}, 1 \mathrm{H}), 7.50-7.31(\mathrm{~m}, 5 \mathrm{H}), 7.16$ (dd, $J=8.3,2.2 \mathrm{~Hz}, 1 \mathrm{H}), 7.04(\mathrm{~m}, 2 \mathrm{H}), 2.33(\mathrm{~s}, 3 \mathrm{H}), 1.99(\mathrm{~s}, 3 \mathrm{H})$.

${ }^{13}$ C-NMR $\left(126 \mathrm{MHz}, \mathrm{CDCl}_{3}\right): \delta=168.0\left(\mathrm{C}_{\mathrm{q}}\right), 138.3\left(\mathrm{C}_{\mathrm{q}}\right), 134.0\left(\mathrm{C}_{\mathrm{q}}\right), 132.3\left(\mathrm{C}_{\mathrm{q}}\right), 132.0\left(\mathrm{C}_{\mathrm{q}}\right)$, $131.0(\mathrm{CH}), 129.1(\mathrm{CH}), 128.9(\mathrm{CH}), 128.8(\mathrm{CH}), 127.7(\mathrm{CH}), 121.9(\mathrm{CH}), 24.5\left(\mathrm{CH}_{3}\right), 20.9$ $\left(\mathrm{CH}_{3}\right)$.

IR (ATR): 3235, 3057, 3029, 2922, 1655, 1524, 1505, 1488, 1366, $761 \mathrm{~cm}^{-1}$.

MS (EI) $m / z$ (relative intensity): 225 ([ $\left.\mathrm{M}^{+}\right]$54), 183 (100), 167 (18), 43 (22).

HR-MS (EI) $m / z$ for $\mathrm{C}_{15} \mathrm{H}_{15} \mathrm{NO}\left[\mathrm{M}^{+}\right] \quad$ calcd.: 225.1154 .

found: 225.1154 .

The analytical data are in accordance with those reported in the literature. ${ }^{[163 b]}$ 


\section{Synthesis of $N$-(5-Ethyl-[1,1'-biphenyl]-2-yl)acetamide (33ka)}

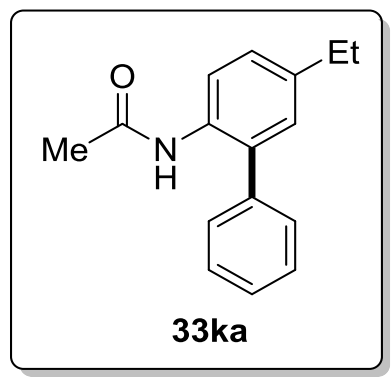

The general procedure A was followed using 30k (163 mg, $1.00 \mathrm{mmol})$ and phenylboronic acid (73a) (183 mg, $1.50 \mathrm{mmol})$. Purification by column chromatography (n-hexane/EtOAc: $7 / 3$ ) yielded 33ka (151 mg, 63\%) as a colorless solid.

M. p.: $64-65^{\circ} \mathrm{C}$.

${ }^{1} \mathbf{H}-\mathbf{N M R}\left(300 \mathrm{MHz}, \mathrm{CDCl}_{3}\right): \delta=8.07(\mathrm{~d}, J=8.3 \mathrm{~Hz}, 1 \mathrm{H}), 7.54-7.31(\mathrm{~m}, 5 \mathrm{H}), 7.20$ (dd, $J=8.3,2.3 \mathrm{~Hz}, 1 \mathrm{H}), 7.13(\mathrm{~s}, 1 \mathrm{H}), 7.09$ (d, $J=2.3 \mathrm{~Hz}, 1 \mathrm{H}), 2.65$ (q, $J=7.6 \mathrm{~Hz}, 2 \mathrm{H}), 2.00(\mathrm{~s}$, $3 \mathrm{H}), 1.25(\mathrm{t}, J=7.6 \mathrm{~Hz}, 3 \mathrm{H})$.

${ }^{13}$ C-NMR $\left(126 \mathrm{MHz}, \mathrm{CDCl}_{3}\right): \delta=168.0\left(\mathrm{C}_{\mathrm{q}}\right), 140.3\left(\mathrm{C}_{\mathrm{q}}\right), 138.3\left(\mathrm{C}_{\mathrm{q}}\right), 132.5\left(\mathrm{C}_{\mathrm{q}}\right), 132.1\left(\mathrm{C}_{\mathrm{q}}\right)$, $129.3(\mathrm{CH}), 129.0(\mathrm{CH}), 128.8(\mathrm{CH}), 127.6(\mathrm{CH}), 127.5(\mathrm{CH}), 122.2(\mathrm{CH}), 28.3\left(\mathrm{CH}_{2}\right), 24.4$ $\left(\mathrm{CH}_{3}\right), 15.6\left(\mathrm{CH}_{3}\right)$.

IR (ATR): 3267, 3027, 2964, 2930, 2871, 1659, 1513, 1487, 1297, $767 \mathrm{~cm}^{-1}$.

MS (EI) $m / z$ (relative intensity): 239 ([M $\left.\mathrm{M}^{+}\right]$58), 197 (58), 182 (100), 180 (19), 167 (16), 43 (37).

HR-MS (EI) $m / z$ for $\mathrm{C}_{16} \mathrm{H}_{17} \mathrm{NO}\left[\mathbf{M}^{+}\right]$

calcd.: 239.1310 .

found: 239.1306 . 


\section{Synthesis of $N$-(5-Methoxy-[1,1'-biphenyl]-2-yl)acetamide (33la)}

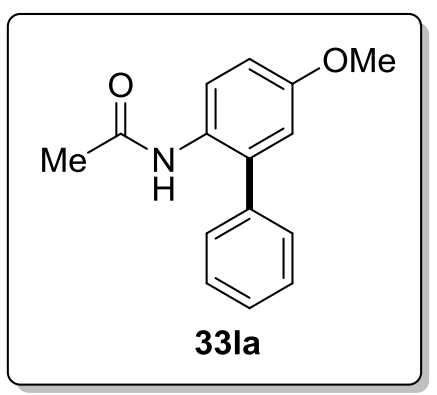

The general procedure A was followed using 301 (165 mg, $1.00 \mathrm{mmol})$ and phenylboronic acid (73a) (183 mg, $1.50 \mathrm{mmol})$. Purification by column chromatography ( $n$-hexane/EtOAc: $1 / 1)$ yielded 33la (183 mg, 76\%) as a colorless solid.

M. p.: $112-114^{\circ} \mathrm{C}$.

${ }^{1} \mathbf{H}-\mathbf{N M R}\left(300 \mathrm{MHz}, \mathrm{CDCl}_{3}\right): \delta=7.95(\mathrm{~d}, J=8.9 \mathrm{~Hz}, 1 \mathrm{H}), 7.50-7.28(\mathrm{~m}, 5 \mathrm{H}), 6.98(\mathrm{~s}, 1 \mathrm{H})$, $6.88(\mathrm{dd}, J=8.9,3.0 \mathrm{~Hz}, 1 \mathrm{H}), 6.78(\mathrm{~d}, J=3.0 \mathrm{~Hz}, 1 \mathrm{H}), 3.78(\mathrm{~s}, 3 \mathrm{H}), 1.97$ (s, 3H).

${ }^{13}$ C-NMR $\left(126 \mathrm{MHz}, \mathrm{CDCl}_{3}\right): \delta=168.2\left(\mathrm{C}_{\mathrm{q}}\right), 156.3\left(\mathrm{C}_{\mathrm{q}}\right), 138.1\left(\mathrm{C}_{\mathrm{q}}\right), 134.7\left(\mathrm{C}_{\mathrm{q}}\right), 128.9(\mathrm{CH})$, $128.8(\mathrm{CH}), 127.8(\mathrm{CH}), 127.6\left(\mathrm{C}_{\mathrm{q}}\right), 124.3(\mathrm{CH}), 115.3(\mathrm{CH}), 113.3(\mathrm{CH}), 55.5\left(\mathrm{CH}_{3}\right), 24.2$ $\left(\mathrm{CH}_{3}\right)$.

IR (ATR): 3263, 3058, 2969, 2939, 2838, 1664, 1480, 1270, 1178, $701 \mathrm{~cm}^{-1}$.

MS (EI) $m / z$ (relative intensity): 241 ([M $\left.\mathrm{M}^{+}\right]$71), 199 (76), 184 (100), 154 (21), 128 (11), 43 (34).

HR-MS (EI) $m / z$ for $\mathrm{C}_{15} \mathrm{H}_{15} \mathrm{NO}_{2}\left[\mathrm{M}^{+}\right]$

calcd.: 241.1103.

found: 241.1106.

The analytical data are in accordance with those reported in the literature. ${ }^{[163 b]}$ 


\section{Synthesis of $N$-(4-Methoxy-[1,1'-biphenyl]-2-yl)acetamide (33ma)}

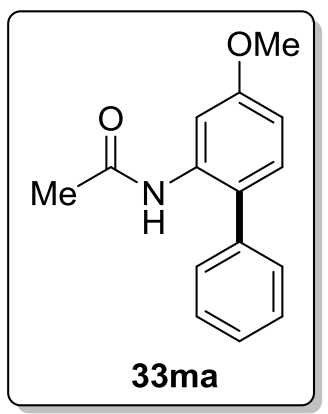

The general procedure A was followed using 30m (165 mg, $1.00 \mathrm{mmol})$ and phenylboronic acid (73a) (183 mg, $1.50 \mathrm{mmol})$. Purification by column chromatography ( $n$-hexane/EtOAc: $7 / 3$ ) yielded 33ma (174 mg, 72\%) as a colorless solid.

The general procedure $\mathbf{C}$ was followed using $30 \mathrm{~m}(82.6 \mathrm{mg}, 0.50 \mathrm{mmol})$ and potassium phenyltrifluoroborate (77a) (276 mg, $1.50 \mathrm{mmol})$. Purification by column chromatography ( $n$-hexane/EtOAc: 7/3) yielded 33ma (64 mg, 53\%) as a colorless solid.

M. p.: $91-93{ }^{\circ} \mathrm{C}$.

${ }^{\mathbf{1}} \mathbf{H}$-NMR $\left(300 \mathrm{MHz}, \mathrm{CDCl}_{3}\right): \delta=7.98(\mathrm{~d}, J=2.6 \mathrm{~Hz}, 1 \mathrm{H}), 7.49-7.42(\mathrm{~m}, 2 \mathrm{H}), 7.40-7.36(\mathrm{~m}$, 1H), 7.35-7.29 (m, 2H), $7.17(\mathrm{~s}, 1 \mathrm{H}), 7.12(\mathrm{~d}, J=8.5 \mathrm{~Hz}, 1 \mathrm{H}), 6.72(\mathrm{dd}, J=8.5,2.6 \mathrm{~Hz}, 1 \mathrm{H})$, $3.84(\mathrm{~s}, 3 \mathrm{H}), 2.00(\mathrm{~s}, 3 \mathrm{H})$.

${ }^{13}$ C-NMR $\left(126 \mathrm{MHz}, \mathrm{CDCl}_{3}\right): \delta=168.1\left(\mathrm{C}_{\mathrm{q}}\right), 159.4\left(\mathrm{C}_{\mathrm{q}}\right), 137.9\left(\mathrm{C}_{\mathrm{q}}\right), 135.6\left(\mathrm{C}_{\mathrm{q}}\right), 130.6(\mathrm{CH})$, $129.3(\mathrm{CH}), 129.0(\mathrm{CH}), 127.6(\mathrm{CH}), 124.2\left(\mathrm{C}_{\mathrm{q}}\right), 110.5(\mathrm{CH}), 106.2(\mathrm{CH}), 55.5\left(\mathrm{CH}_{3}\right), 24.8$ $\left(\mathrm{CH}_{3}\right)$.

IR (ATR): 3241, 3033, 2953, 2831, 1652, 1309, 1233, 762, 724, $698 \mathrm{~cm}^{-1}$.

MS (EI) $m / z$ (relative intensity): 241 ([ $\left.\mathrm{M}^{+}\right]$74), 199 (100), 170 (16), 156 (19), 84 (9), 43 (34).

HR-MS (EI) $m / z$ for $\mathrm{C}_{15} \mathrm{H}_{15} \mathrm{NO}_{2}\left[\mathbf{M}^{+}\right]$

calcd.: 241.1103 .

found: 241.1107.

The analytical data are in accordance with those reported in the literature. ${ }^{[27]}$ 


\section{Synthesis of $N$-(2-Phenylnaphthalen-1-yl)acetamide (33na)}

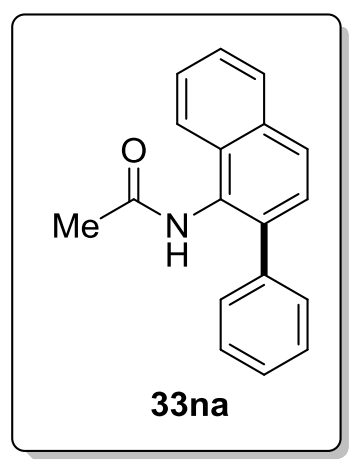

The general procedure A was followed using 30n (185 mg, $1.00 \mathrm{mmol})$ and phenylboronic acid (73a) (183 mg, $1.50 \mathrm{mmol})$. Purification by column chromatography (n-hexane/EtOAc: 7/3) yielded 33na (76 mg, 29\%) as a colorless solid.

M. p.: $135-136^{\circ} \mathrm{C}$.

${ }^{\mathbf{1}} \mathbf{H}-\mathbf{N M R}\left(300 \mathrm{MHz}, \mathrm{CDCl}_{3}\right): \delta=8.01-7.90(\mathrm{~m}, 2 \mathrm{H}), 7.70-7.28(\mathrm{~m}, 10 \mathrm{H}), 2.13(\mathrm{~s}, 3 \mathrm{H})$.

${ }^{13}$ C-NMR $\left(126 \mathrm{MHz}, \mathrm{CDCl}_{3}\right): \delta=173.7\left(\mathrm{C}_{\mathrm{q}}\right), 139.0\left(\mathrm{C}_{\mathrm{q}}\right), 138.3\left(\mathrm{C}_{\mathrm{q}}\right), 133.9\left(\mathrm{C}_{\mathrm{q}}\right), 132.8\left(\mathrm{C}_{\mathrm{q}}\right)$, $130.6\left(\mathrm{C}_{\mathrm{q}}\right), 129.7(\mathrm{CH}), 128.7(\mathrm{CH}), 128.5(\mathrm{CH}), 128.4(\mathrm{CH}), 128.3(\mathrm{CH}), 128.2(\mathrm{CH}), 128.1$ $(\mathrm{CH}), 126.7(\mathrm{CH}), 122.1(\mathrm{CH}), 26.2\left(\mathrm{CH}_{3}\right)$.

IR (ATR): 3059, 2955, 2923, 2853, 1700, 1364, 1223, 994, 826, $760 \mathrm{~cm}^{-1}$.

MS (EI) $m / z$ (relative intensity): $261\left(\left[\mathrm{M}^{+}\right] 61\right), 219$ (100), 43 (19).

HR-MS (EI) $m / z$ for $\mathrm{C}_{18} \mathrm{H}_{15} \mathrm{NO}\left[\mathrm{M}^{+}\right]$ calcd.: 261.1154 . found: 261.1153 .

The analytical data are in accordance with those reported in the literature. ${ }^{[171]}$ 


\section{Synthesis of $N-\left(\left[1,1^{\prime}: 3^{\prime}, 1^{\prime \prime}-\right.\right.$ Terphenyl]-4'-yl)acetamide (33oa)}

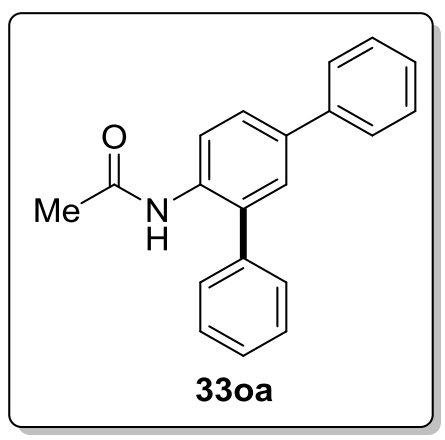

The general procedure A was followed using $\mathbf{3 0 0}(211 \mathrm{mg}, 1.00 \mathrm{mmol})$ and phenylboronic acid (73a) (183 mg, $1.50 \mathrm{mmol})$. Purification by column chromatography ( $n$-hexane/EtOAc: $7 / 3$ ) yielded $330 a(155 \mathrm{mg}, 54 \%)$ as a colorless solid.

M. p.: $114-115^{\circ} \mathrm{C}$.

${ }^{\mathbf{1}} \mathbf{H}$-NMR $\left(300 \mathrm{MHz}, \mathrm{CDCl}_{3}\right): \delta=8.34(\mathrm{~d}, J=8.5 \mathrm{~Hz}, 1 \mathrm{H}), 7.63-7.55(\mathrm{~m}, 3 \mathrm{H}), 7.54-7.36(\mathrm{~m}$, $8 \mathrm{H}), 7.33$ (d, $J=7.2 \mathrm{~Hz}, 1 \mathrm{H}), 7.17$ (s, 1H), 2.03 (s, 3H).

${ }^{13}$ C-NMR $\left(126 \mathrm{MHz}, \mathrm{CDCl}_{3}\right): \delta=168.3\left(\mathrm{C}_{\mathrm{q}}\right), 140.4\left(\mathrm{C}_{\mathrm{q}}\right), 138.2\left(\mathrm{C}_{\mathrm{q}}\right), 137.2\left(\mathrm{C}_{\mathrm{q}}\right), 134.1\left(\mathrm{C}_{\mathrm{q}}\right)$, $132.6\left(\mathrm{C}_{\mathrm{q}}\right), 129.3(\mathrm{CH}), 129.2(\mathrm{CH}), 128.8(\mathrm{CH}), 128.7(\mathrm{CH}), 128.2(\mathrm{CH}), 127.3(\mathrm{CH}), 127.0$ $(\mathrm{CH}), 126.9(\mathrm{CH}), 121.9(\mathrm{CH}), 24.5\left(\mathrm{CH}_{3}\right)$.

IR (ATR): 3289, 3029, 2925, 1651, 1503, 1478, 760, 694, 649, $598 \mathrm{~cm}^{-1}$.

MS (EI) $m / z$ (relative intensity): 287 ([ $\left.\mathrm{M}^{+}\right]$46), 245 (100), 43 (19).

HR-MS (EI) $m / z$ for $\mathrm{C}_{20} \mathrm{H}_{17} \mathrm{NO}\left[\mathrm{M}^{+}\right]$ calcd.: 287.1310. found: 287.1316 . 


\section{Synthesis of $N$-(5-Hydroxy-[1,1'-biphenyl]-2-yl)acetamide (33pa)}

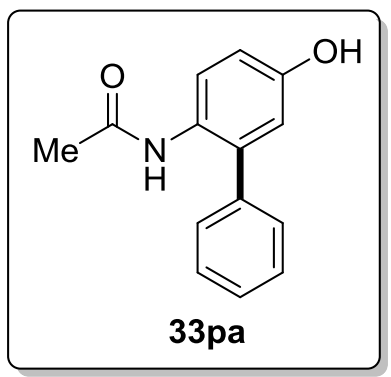

The general procedure A was followed using 30p (151 mg, $1.00 \mathrm{mmol})$ and phenylboronic acid (73a) (183 mg, $1.50 \mathrm{mmol})$. Purification by column chromatography ( $n$-hexane/EtOAc: $3 / 7$ ) yielded 33pa (157 mg, 69\%) as a pale yellow viscous oil.

${ }^{1} \mathbf{H}-\mathbf{N M R}\left(300 \mathrm{MHz}, \mathrm{CDCl}_{3}\right): \delta=7.59(\mathrm{~d}, J=9.5 \mathrm{~Hz}, 1 \mathrm{H}), 7.53(\mathrm{~s}, 1 \mathrm{H}), 7.43-7.32(\mathrm{~m}, 3 \mathrm{H})$, 7.30-7.24 (m, 2H), 7.05 (s, 1H), 6.73-6.67 (m, 2H), 1.99 (s, 3H).

${ }^{13}$ C-NMR $\left(126 \mathrm{MHz}, \mathrm{CDCl}_{3}\right): \delta=169.7\left(\mathrm{C}_{\mathrm{q}}\right), 154.1\left(\mathrm{C}_{\mathrm{q}}\right), 138.1\left(\mathrm{C}_{\mathrm{q}}\right), 136.1\left(\mathrm{C}_{\mathrm{q}}\right), 128.8(\mathrm{CH})$, 128.6 (CH), $127.6(\mathrm{CH}), 126.0\left(\mathrm{C}_{\mathrm{q}}\right), 125.7(\mathrm{CH}), 117.1(\mathrm{CH}), 115.3(\mathrm{CH}), 23.9\left(\mathrm{CH}_{3}\right)$.

IR (ATR): 3268, 3057, 2959, 2795, 1524, 1488, 1433, 1299, 1199, $726 \mathrm{~cm}^{-1}$.

MS (EI) $m / z$ (relative intensity): 227 ([M $\left.\mathrm{M}^{+}\right]$44), 185 (100), 154 (11), 43 (14).

HR-MS (EI) $m / z$ for $\mathrm{C}_{14} \mathrm{H}_{13} \mathrm{NO}_{2}\left[\mathrm{M}^{+}\right]$ calcd.: 227.0946 . found: 227.0945 . 


\section{Synthesis of $N$-(5-Fluoro-[1,1'-biphenyl]-2-yl)acetamide (33qa)}

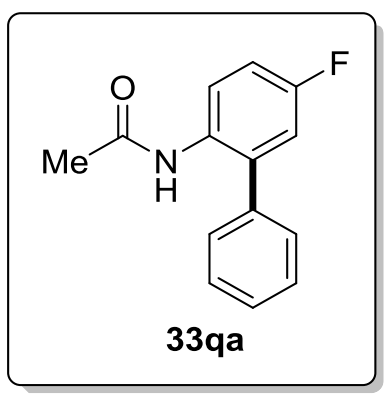

The general procedure A was followed using 30q $(153 \mathrm{mg}, 1.00 \mathrm{mmol})$ and phenylboronic acid (73a) (183 mg, $1.50 \mathrm{mmol})$. Purification by column chromatography ( $n$-hexane/EtOAc: 7/3) yielded 33qa (163 mg, 71\%) as a colorless solid.

M. p.: $131-133^{\circ} \mathrm{C}$.

${ }^{1} \mathbf{H}-\mathbf{N M R}\left(300 \mathrm{MHz}, \mathrm{CDCl}_{3}\right): \delta=8.20-8.05(\mathrm{~m}, 1 \mathrm{H}), 7.59-7.28(\mathrm{~m}, 5 \mathrm{H}), 7.17-6.88(\mathrm{~m}, 3 \mathrm{H})$, $2.00(\mathrm{~s}, 3 \mathrm{H})$.

${ }^{13}$ C-NMR $\left(126 \mathrm{MHz}, \mathrm{CDCl}_{3}\right): \delta=168.1\left(\mathrm{C}_{\mathrm{q}}\right), 159.1\left(\mathrm{C}_{\mathrm{q}}, J_{\mathrm{C}-\mathrm{F}}=244.1 \mathrm{~Hz}\right), 137.0\left(\mathrm{C}_{\mathrm{q}}\right.$, $\left.J_{\mathrm{C}-\mathrm{F}}=1.5 \mathrm{~Hz}\right), 134.4\left(\mathrm{C}_{\mathrm{q}}, J_{\mathrm{C}-\mathrm{F}}=7.7 \mathrm{~Hz}\right), 130.6\left(\mathrm{C}_{\mathrm{q}}, J_{\mathrm{C}-\mathrm{F}}=2.9 \mathrm{~Hz}\right), 129.0(\mathrm{CH}), 128.9(\mathrm{CH})$, $128.3(\mathrm{CH}), \quad 123.9\left(\mathrm{CH}, \quad J_{\mathrm{C}-\mathrm{F}}=8.1 \mathrm{~Hz}\right), \quad 116.5\left(\mathrm{CH}, \quad J_{\mathrm{C}-\mathrm{F}}=22.9 \mathrm{~Hz}\right), 114.8(\mathrm{CH}$, $\left.J_{\mathrm{C}-\mathrm{F}}=21.8 \mathrm{~Hz}\right), 24.4\left(\mathrm{CH}_{3}\right)$.

${ }^{19}$ F-NMR $\left(282 \mathrm{MHz}, \mathrm{CDCl}_{3}\right): \delta=-(117.76-118.03)(\mathrm{m})$.

IR (ATR): 3274, 3238, 3031, 1659, 1533, 1483, 1410, 1180, 871, $771 \mathrm{~cm}^{-1}$.

MS (EI) $m / z$ (relative intensity): 229 ([M+ $]$ 34), 187 (100), 104 (14), 84 (14), 43 (21).

HR-MS (EI) $m / z$ for $\mathrm{C}_{14} \mathrm{H}_{12} \mathrm{FNO}\left[\mathrm{M}^{+}\right]$ calcd.: 229.0903 . found: 229.0904 .

The analytical data are in accordance with those reported in the literature. ${ }^{[163 b]}$ 


\section{Synthesis of $N$-(5-Chloro-[1,1'-biphenyl]-2-yl)acetamide (33ra)}

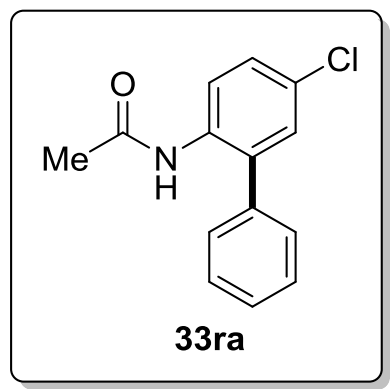

The general procedure A was followed using 30r (169 mg, $1.00 \mathrm{mmol})$ and phenylboronic acid (73a) (183 mg, $1.50 \mathrm{mmol})$. Purification by column chromatography ( $n$-hexane/EtOAc: 7/3) yielded 33ra (165 mg, 67\%) as a colorless solid.

M. p.: $126-127^{\circ} \mathrm{C}$.

${ }^{1} \mathbf{H}-\mathbf{N M R}\left(300 \mathrm{MHz}, \mathrm{CDCl}_{3}\right): \delta=8.20(\mathrm{~d}, J=8.8 \mathrm{~Hz}, 1 \mathrm{H}), 7.50-7.39(\mathrm{~m}, 3 \mathrm{H}), 7.34-7.27$ (m, $3 \mathrm{H}), 7.20(\mathrm{~d}, J=2.5 \mathrm{~Hz}, 1 \mathrm{H}), 7.10(\mathrm{~s}, 1 \mathrm{H}), 1.98(\mathrm{~s}, 3 \mathrm{H})$.

${ }^{13}$ C-NMR $\left(126 \mathrm{MHz}, \mathrm{CDCl}_{3}\right): \delta=168.0\left(\mathrm{C}_{\mathrm{q}}\right), 136.7\left(\mathrm{C}_{\mathrm{q}}\right), 133.6\left(\mathrm{C}_{\mathrm{q}}\right), 133.2\left(\mathrm{C}_{\mathrm{q}}\right), 129.6(\mathrm{CH})$, $129.3\left(\mathrm{C}_{\mathrm{q}}\right), 129.1(\mathrm{CH}), 128.9(\mathrm{CH}), 128.3(\mathrm{CH}), 128.1(\mathrm{CH}), 122.8(\mathrm{CH}), 24.5\left(\mathrm{CH}_{3}\right)$.

IR (ATR): 3257, 3188, 3029, 1647, 1520, 1390, 1367, 820, 767, $699 \mathrm{~cm}^{-1}$.

MS (EI) $m / z$ (relative intensity): 245 ([M+] 36), 203 (100), 167 (44), 139 (12), 43 (34).

HR-MS (EI) $m / z$ for $\mathrm{C}_{14} \mathrm{H}_{12} \mathrm{ClNO}\left[\mathrm{M}^{+}\right] \quad$ calcd.: 245.0607 . found: 245.0604 .

The analytical data are in accordance with those reported in the literature. ${ }^{[163 b]}$ 


\section{Synthesis of $N$-(5-Bromo-[1,1'-biphenyl]-2-yl)acetamide (33sa)}

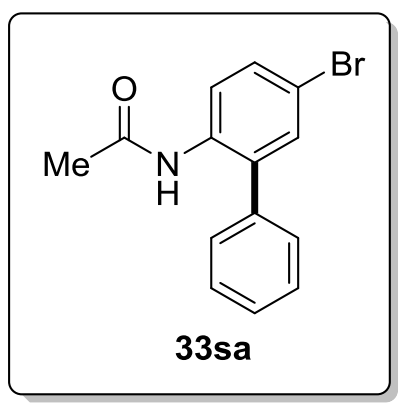

The general procedure A was followed using 30s $(214 \mathrm{mg}, 1.00 \mathrm{mmol})$ and phenylboronic acid (73a) (183 mg, $1.50 \mathrm{mmol})$. Purification by column chromatography ( $n$-hexane/EtOAc: $7 / 3)$ yielded 33sa $(182 \mathrm{mg}, 63 \%)$ as a colorless solid.

M. p.: $127-128^{\circ} \mathrm{C}$.

${ }^{1} \mathbf{H}-\mathbf{N M R}\left(300 \mathrm{MHz}, \mathrm{CDCl}_{3}\right): \delta=8.21(\mathrm{~d}, J=8.7 \mathrm{~Hz}, 1 \mathrm{H}), 7.55-7.43(\mathrm{~m}, 4 \mathrm{H}), 7.41-7.30(\mathrm{~m}$, $3 \mathrm{H}), 7.08(\mathrm{~s}, 1 \mathrm{H}), 2.01(\mathrm{~s}, 3 \mathrm{H})$.

${ }^{13}$ C-NMR $\left(126 \mathrm{MHz}, \mathrm{CDCl}_{3}\right): \delta=168.2\left(\mathrm{C}_{\mathrm{q}}\right), 136.8\left(\mathrm{C}_{\mathrm{q}}\right), 134.0\left(\mathrm{C}_{\mathrm{q}}\right), 133.9\left(\mathrm{C}_{\mathrm{q}}\right), 132.7(\mathrm{CH})$, $131.3(\mathrm{CH}), 129.4(\mathrm{CH}), 129.1(\mathrm{CH}), 128.6(\mathrm{CH}), 123.0(\mathrm{CH}), 116.9\left(\mathrm{C}_{\mathrm{q}}\right), 24.5\left(\mathrm{CH}_{3}\right)$.

IR (ATR): 3278, 3055, 3025, 1651, 1515, 1386, 1369, 768, 700, $672 \mathrm{~cm}^{-1}$.

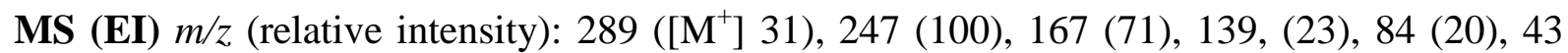
(32).

HR-MS (EI) $m / z$ for $\mathrm{C}_{14} \mathrm{H}_{12} \mathrm{BrNO}\left[\mathrm{M}^{+}\right] \quad$ calcd.: 289.0102 .

found: 289.0103 .

The analytical data are in accordance with those reported in the literature. ${ }^{[163 b]}$ 


\section{Synthesis of Methyl 6-acetamido-[1,1'-biphenyl]-3-carboxylate (33ta)}

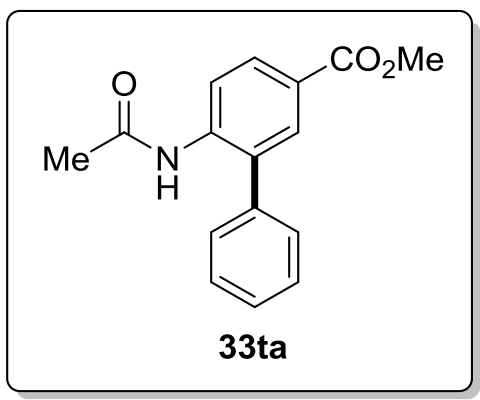

The general procedure A was followed using 30t (193 mg, $1.00 \mathrm{mmol})$ and phenylboronic acid (73a) $\quad(183 \mathrm{mg}, \quad 1.50 \mathrm{mmol})$. Purification by column chromatography ( $n$-hexane/EtOAc: $7 / 3$ ) yielded 33ta (156 mg, 58\%) as a colorless solid.

M. p.: $136-137^{\circ} \mathrm{C}$.

${ }^{1}$ H-NMR $\left(300 \mathrm{MHz}, \mathrm{CDCl}_{3}\right): \delta=8.46(\mathrm{~d}, J=8.7 \mathrm{~Hz}, 1 \mathrm{H}), 8.01(\mathrm{dd}, J=8.7,2.1 \mathrm{~Hz}, 1 \mathrm{H})$, $7.90(\mathrm{~d}, J=2.1 \mathrm{~Hz}, 1 \mathrm{H}), 7.54-7.40(\mathrm{~m}, 3 \mathrm{H}), 7.38-7.34(\mathrm{~m}, 2 \mathrm{H}), 7.31(\mathrm{~s}, 1 \mathrm{H}), 3.87(\mathrm{~s}, 3 \mathrm{H})$, $2.02(\mathrm{~s}, 3 \mathrm{H})$.

${ }^{13}$ C-NMR (126 MHz, $\left.\mathrm{CDCl}_{3}\right): \delta=168.1\left(\mathrm{C}_{\mathrm{q}}\right), 166.4\left(\mathrm{C}_{\mathrm{q}}\right), 138.8\left(\mathrm{C}_{\mathrm{q}}\right), 136.9\left(\mathrm{C}_{\mathrm{q}}\right), 131.4(\mathrm{CH})$, $131.0\left(\mathrm{C}_{\mathrm{q}}\right), 130.0(\mathrm{CH}), 129.3(\mathrm{CH}), 129.1(\mathrm{CH}), 128.4(\mathrm{CH}), 125.3\left(\mathrm{C}_{\mathrm{q}}\right), 120.0(\mathrm{CH}), 52.1$ $\left(\mathrm{CH}_{3}\right), 24.9\left(\mathrm{CH}_{3}\right)$.

IR (ATR): 3358, 3030, 2949, 1711, 1679, 1585, 1511, 1296, 1106, $770 \mathrm{~cm}^{-1}$.

MS (EI) $m / z$ (relative intensity): 269 ([M+] 49), 227 (100), 196 (92), 167 (29), 43 (21).

HR-MS (EI) $m / z$ for $\mathrm{C}_{16} \mathrm{H}_{15} \mathrm{NO}_{3}\left[\mathbf{M}^{+}\right]$ calcd.: 269.1052 . found: 269.1056 . 


\section{Synthesis of $N$-(4'-Methyl-[1,1'-biphenyl]-2-yl)acetamide (33ab)}

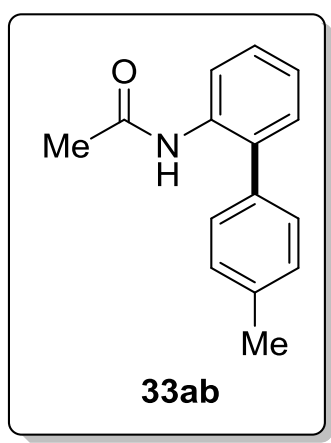

The general procedure A was followed using 30a $(135 \mathrm{mg}, 1.00 \mathrm{mmol})$ and $p$-tolylboronic acid (73b) (204 mg, $1.50 \mathrm{mmol})$. Purification by column chromatography ( $n$-hexane/EtOAc: $7 / 3$ ) yielded 33ab (185 mg, 82\%) as a colorless solid.

The general procedure B was followed using 30a $(135 \mathrm{mg}, 1.00 \mathrm{mmol})$ and hydroxydip-tolylborane (76b) $(315 \mathrm{mg}, 1.50 \mathrm{mmol})$. Purification by column chromatography ( $n$-hexane/EtOAc: 7/3) yielded 33ab (133 mg, 59\%) as a colorless solid.

The general procedure $\mathbf{C}$ was followed using 30a $(67.6 \mathrm{mg}, 0.50 \mathrm{mmol})$ and potassium p-tolyltrifluoroborate (77b) (297 mg, $1.50 \mathrm{mmol})$. Purification by column chromatography (n-hexane/EtOAc: 7/3) yielded 33ab (71 mg, 63\%) as a colorless solid.

M. p.: $106-108^{\circ} \mathrm{C}$.

${ }^{1} \mathbf{H}-\mathbf{N M R}\left(300 \mathrm{MHz}, \mathrm{CDCl}_{3}\right): \delta=8.24(\mathrm{~d}, J=8.2 \mathrm{~Hz}, 1 \mathrm{H}), 7.44-7.06(\mathrm{~m}, 8 \mathrm{H}), 2.41(\mathrm{~s}, 3 \mathrm{H})$, $2.01(\mathrm{~s}, 3 \mathrm{H})$.

${ }^{13}$ C-NMR $\left(126 \mathrm{MHz}, \mathrm{CDCl}_{3}\right): \delta=168.0\left(\mathrm{C}_{\mathrm{q}}\right), 137.6\left(\mathrm{C}_{\mathrm{q}}\right), 135.0\left(\mathrm{C}_{\mathrm{q}}\right), 134.6\left(\mathrm{C}_{\mathrm{q}}\right), 132.0\left(\mathrm{C}_{\mathrm{q}}\right)$, $130.0(\mathrm{CH}), 129.7(\mathrm{CH}), 128.9(\mathrm{CH}), 128.1(\mathrm{CH}), 124.1(\mathrm{CH}), 121.4(\mathrm{CH}), 24.6\left(\mathrm{CH}_{3}\right), 21.2$ $\left(\mathrm{CH}_{3}\right)$.

IR (ATR): 3340, 2956, 2921, 2853, 1515, 1442, 1282, 817, 756, $680 \mathrm{~cm}^{-1}$.

MS (EI) $m / z$ (relative intensity): 225 ([ $\left.\mathrm{M}^{+}\right]$55), 183 (100), 167 (37), 43 (26). 
HR-MS (EI) $m / z$ for $\mathrm{C}_{15} \mathrm{H}_{15} \mathrm{NO}\left[\mathrm{M}^{+}\right]$

calcd.: 225.1154 .

found: 225.1149 .

The analytical data are in accordance with those reported in the literature. ${ }^{[27]}$

Synthesis of $N$-\{2-(Naphthalen-2-yl)phenyl $\}$ acetamide (33ac)

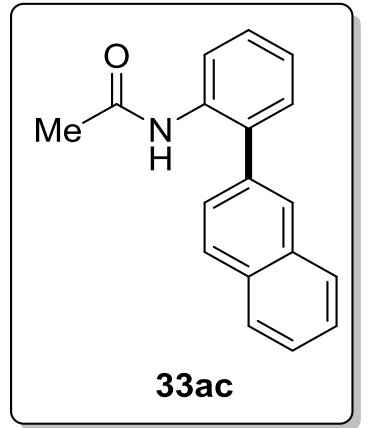

The general procedure A was followed using 30a $(135 \mathrm{mg}, 1.00 \mathrm{mmol})$ and naphthalen-2ylboronic acid (73c) $(258 \mathrm{mg}, 1.50 \mathrm{mmol})$. Purification by column chromatography ( $n$-hexane/EtOAc: $7 / 3$ ) yielded 33ac (167 mg, 64\%) as a colorless solid.

M. p.: $131-132{ }^{\circ} \mathrm{C}$.

${ }^{1} \mathbf{H}-\mathbf{N M R}\left(300 \mathrm{MHz}, \mathrm{CDCl}_{3}\right): \delta=8.30(\mathrm{~d}, J=8.2 \mathrm{~Hz}, 1 \mathrm{H}), 8.00-7.82(\mathrm{~m}, 4 \mathrm{H}), 7.61-7.53(\mathrm{~m}$, 2H), $7.49(\mathrm{dd}, J=8.4,1.7 \mathrm{~Hz}, 1 \mathrm{H}), 7.41(\mathrm{td}, J=7.8,1.7 \mathrm{~Hz}, 1 \mathrm{H}), 7.35(\mathrm{~d}, J=6.8 \mathrm{~Hz}, 1 \mathrm{H})$, 7.28-7.12 (m, 2H), $1.99(\mathrm{~s}, 3 \mathrm{H})$.

${ }^{13}$ C-NMR $\left(126 \mathrm{MHz}, \mathrm{CDCl}_{3}\right): \delta=168.3\left(\mathrm{C}_{\mathrm{q}}\right), 135.5\left(\mathrm{C}_{\mathrm{q}}\right), 134.9\left(\mathrm{C}_{\mathrm{q}}\right), 133.5\left(\mathrm{C}_{\mathrm{q}}\right), 132.6\left(\mathrm{C}_{\mathrm{q}}\right)$, $132.1\left(\mathrm{C}_{\mathrm{q}}\right), 130.2(\mathrm{CH}), 128.7(\mathrm{CH}), 128.5(\mathrm{CH}), 128.3(\mathrm{CH}), 128.0(\mathrm{CH}), 127.8(\mathrm{CH}), 127.0$ $(\mathrm{CH}), 126.7(\mathrm{CH}), 126.6(\mathrm{CH}), 124.4(\mathrm{CH}), 121.8(\mathrm{CH}), 24.6\left(\mathrm{CH}_{3}\right)$.

IR (ATR): 3261, 3053, 3025, 1643, 1522, 1443, 1368, 1275, 856, $817 \mathrm{~cm}^{-1}$.

MS (EI) $m / z$ (relative intensity): 261 ([M+] 47), 219 (100), 189 (14), 43 (17).

HR-MS (EI) $m / z$ for $\mathrm{C}_{18} \mathrm{H}_{15} \mathrm{NO}\left[\mathrm{M}^{+}\right] \quad$ calcd.: 261.1154 . found: 261.1153 .

The analytical data are in accordance with those reported in the literature. ${ }^{[172]}$ 


\section{Synthesis of $N$-(4'-Methoxy-[1,1'-biphenyl]-2-yl)acetamide (33ad)}

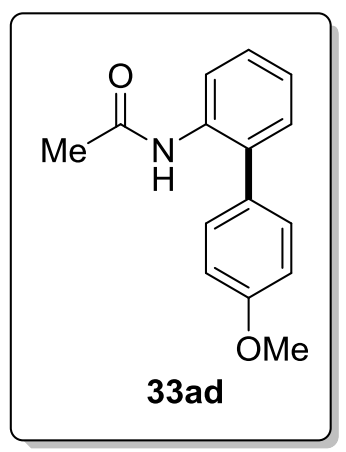

The general procedure $\mathbf{A}$ was followed using $\mathbf{3 0 a}(135 \mathrm{mg}, 1.00 \mathrm{mmol})$ and p-methoxyphenylboronic acid (73d) $(228 \mathrm{mg}, 1.50 \mathrm{mmol})$. Purification by column chromatography ( $n$-hexane/EtOAc: $7 / 3)$ yielded 33ad $(200 \mathrm{mg}, 83 \%)$ as a colorless solid.

The general procedure $\mathbf{B}$ was followed using 30a $(135 \mathrm{mg}, 1.00 \mathrm{mmol})$ and hydroxybis(4methoxyphenyl)borane (76d) (363 mg, $1.50 \mathrm{mmol}$ ). Purification by column chromatography ( $n$-hexane/EtOAc: 7/3) yielded 33ad (150 mg, 62\%) as a colorless solid.

The general procedure $\mathbf{C}$ was followed using $\mathbf{3 0 a}(67.6 \mathrm{mg}, 0.50 \mathrm{mmol})$ and potassium p-methoxyphenyltrifluoroborate $\mathbf{( 7 7 d ) ~}(321 \mathrm{mg}, 1.50 \mathrm{mmol})$. Purification by column chromatography ( $n$-hexane/EtOAc: $7 / 3$ ) yielded 33ad (64 mg, 53\%) as a colorless solid.

M. p.: $135-137^{\circ} \mathrm{C}$.

${ }^{\mathbf{1}} \mathbf{H}$-NMR $\left(300 \mathrm{MHz}, \mathrm{CDCl}_{3}\right): \delta=8.20(\mathrm{~d}, J=8.2 \mathrm{~Hz}, 1 \mathrm{H}), 7.34-7.24(\mathrm{~m}, 3 \mathrm{H}), 7.23-7.09(\mathrm{~m}$, $3 \mathrm{H}), 6.98(\mathrm{~d}, J=8.6 \mathrm{~Hz}, 2 \mathrm{H}), 3.84(\mathrm{~s}, 3 \mathrm{H}), 2.00(\mathrm{~s}, 3 \mathrm{H})$.

${ }^{13}$ C-NMR $\left(126 \mathrm{MHz}, \mathrm{CDCl}_{3}\right): \delta=168.3\left(\mathrm{C}_{\mathrm{q}}\right), 159.3\left(\mathrm{C}_{\mathrm{q}}\right), 134.8\left(\mathrm{C}_{\mathrm{q}}\right), 132.0\left(\mathrm{C}_{\mathrm{q}}\right), 130.3(\mathrm{CH})$, $130.2\left(\mathrm{C}_{\mathrm{q}}\right), 130.1(\mathrm{CH}), 128.0(\mathrm{CH}), 124.3(\mathrm{CH}), 121.6(\mathrm{CH}), 114.4(\mathrm{CH}), 55.2\left(\mathrm{CH}_{3}\right), 24.4$ $\left(\mathrm{CH}_{3}\right)$.

IR (ATR): 3351, 3012, 2921, 2842, 1690, 1439, 1239, 1175, 832, $770 \mathrm{~cm}^{-1}$.

MS (EI) m/z (relative intensity): 241 ([M+ $]$ 54), 199 (100), 184 (37), 154 (24), 128 (12), 43 (30). 
HR-MS (EI) $m / z$ for $\mathrm{C}_{15} \mathrm{H}_{15} \mathrm{NO}_{2}\left[\mathbf{M}^{+}\right]$

calcd.: 241.1103.

found: 241.1110 .

The analytical data are in accordance with those reported in the literature. ${ }^{[27]}$

Synthesis of $N$-\{2-(Benzo[d][1,3]dioxol-5-yl)phenyl $\}$ acetamide (33ae)

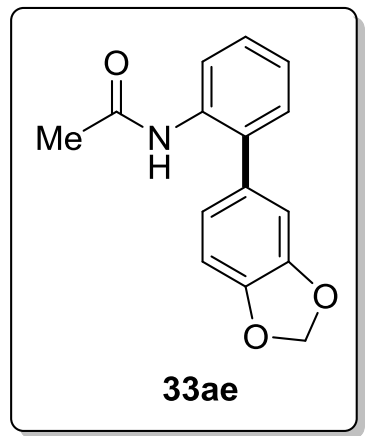

The general procedure A was followed using 30a $(135 \mathrm{mg}, 1.00 \mathrm{mmol})$ and benzo[d][1,3]dioxol-5-ylboronic acid (73e) (249 mg, $1.50 \mathrm{mmol})$. Purification by column chromatography ( $n$-hexane/EtOAc: $7 / 3$ ) yielded 33ae $(174 \mathrm{mg}, 68 \%)$ as a colorless solid.

M. p.: $111-112^{\circ} \mathrm{C}$.

${ }^{1} \mathbf{H}-\mathbf{N M R}\left(300 \mathrm{MHz}, \mathrm{CDCl}_{3}\right): \delta=8.25(\mathrm{~d}, J=8.2 \mathrm{~Hz}, 1 \mathrm{H}), 7.37-7.30(\mathrm{~m}, 1 \mathrm{H}), 7.24-7.08(\mathrm{~m}$, 3H), 6.91 (dd, $J=7.6,0.8 \mathrm{~Hz}, 1 \mathrm{H}), 6.85-6.77$ (m, 2H), 6.03 (s, 2H), 2.04 (s, 3H).

${ }^{13}$ C-NMR $\left(126 \mathrm{MHz}, \mathrm{CDCl}_{3}\right): \delta=168.3\left(\mathrm{C}_{\mathrm{q}}\right), 148.3\left(\mathrm{C}_{\mathrm{q}}\right), 147.5\left(\mathrm{C}_{\mathrm{q}}\right), 134.9\left(\mathrm{C}_{\mathrm{q}}\right), 131.8\left(\mathrm{C}_{\mathrm{q}}\right)$, $131.7\left(\mathrm{C}_{\mathrm{q}}\right), 130.1(\mathrm{CH}), 128.3(\mathrm{CH}), 124.2(\mathrm{CH}), 122.6(\mathrm{CH}), 121.5(\mathrm{CH}), 109.7(\mathrm{CH}), 108.8$ $(\mathrm{CH}), 101.3\left(\mathrm{CH}_{2}\right), 24.6\left(\mathrm{CH}_{3}\right)$.

IR (ATR): 3320, 2890, 1668, 1522, 1445, 1224, 1032, 927, 807, $756 \mathrm{~cm}^{-1}$.

MS (EI) $m / z$ (relative intensity): 255 ([M+ $]$ 65), 213 (100), 182 (13), 154 (34), 127 (12), 43 (30).

HR-MS (EI) $m / z$ for $\mathrm{C}_{15} \mathrm{H}_{13} \mathrm{NO}_{3}\left[\mathbf{M}^{+}\right]$

calcd.: 255.0895 .

found: 255.0901 . 


\section{Synthesis of $N$-(4'-Bromo-[1,1'-biphenyl]-2-yl)acetamide (33af)}

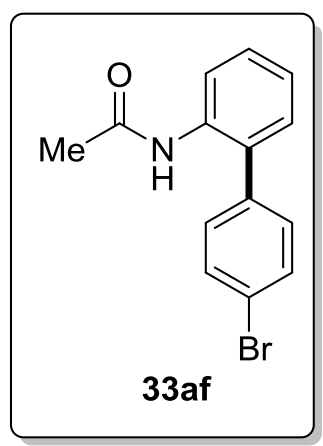

The general procedure $\mathbf{A}$ was followed using $\mathbf{3 0 a}(135 \mathrm{mg}, 1.00 \mathrm{mmol})$ and p-bromophenylboronic acid (73f) $(301 \mathrm{mg}, 1.50 \mathrm{mmol})$. Purification by column chromatography ( $n$-hexane/EtOAc: $7 / 3)$ yielded 33af $(183 \mathrm{mg}, 63 \%)$ as a colorless solid.

M. p.: $138-139^{\circ} \mathrm{C}$.

${ }^{1} \mathbf{H}-\mathbf{N M R}\left(400 \mathrm{MHz}, \mathrm{CDCl}_{3}\right): \delta=8.05(\mathrm{~d}, J=8.2 \mathrm{~Hz}, 1 \mathrm{H}), 7.57-7.53(\mathrm{~m}, 2 \mathrm{H}), 7.32$ (ddd, $J=8.5,6.5,2.5 \mathrm{~Hz}, 1 \mathrm{H}), 7.23-7.11(\mathrm{~m}, 5 \mathrm{H}), 1.97(\mathrm{~s}, 3 \mathrm{H})$.

${ }^{13}$ C-NMR $\left(126 \mathrm{MHz}, \mathrm{CDCl}_{3}\right): \delta=168.4\left(\mathrm{C}_{\mathrm{q}}\right), 137.2\left(\mathrm{C}_{\mathrm{q}}\right), 134.4\left(\mathrm{C}_{\mathrm{q}}\right), 132.1(\mathrm{CH}), 131.8\left(\mathrm{C}_{\mathrm{q}}\right)$, $130.8(\mathrm{CH}), 129.9(\mathrm{CH}), 128.6(\mathrm{CH}), 124.8(\mathrm{CH}), 122.7(\mathrm{CH}), 122.1\left(\mathrm{C}_{\mathrm{q}}\right), 24.1\left(\mathrm{CH}_{3}\right)$.

IR (ATR): 3262, 3056, 3028, 1651, 1524, 1445, 1283, 1070, 826, $758 \mathrm{~cm}^{-1}$.

MS (EI) $m / z$ (relative intensity): 289 ([M+] 29), 247 (100), 167 (65), 139 (18), 43 (29).

HR-MS (EI) $m / z$ for $\mathrm{C}_{14} \mathrm{H}_{12} \mathrm{BrNO}\left[\mathrm{M}^{+}\right] \quad$ calcd.: 289.0102. found: 289.0104 .

The analytical data are in accordance with those reported in the literature. ${ }^{[173]}$ 


\section{Synthesis of $N$-(4'-Chloro-[1,1'-biphenyl]-2-yl)acetamide (33ag)}

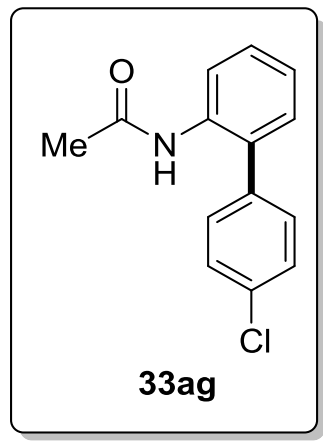

The general procedure A was followed using 30a $(135 \mathrm{mg}, 1.00 \mathrm{mmol})$ and p-chlorophenylboronic acid $\mathbf{( 7 3 g )}(235 \mathrm{mg}, 1.50 \mathrm{mmol})$. Purification by column chromatography (n-hexane/EtOAc: $7 / 3$ ) yielded 33ag (172 mg, 70\%) as a colorless solid.

M. p.: $114-116^{\circ} \mathrm{C}$.

${ }^{1} \mathbf{H}-\mathbf{N M R}\left(300 \mathrm{MHz}, \mathrm{CDCl}_{3}\right): \delta=8.16(\mathrm{~d}, J=8.2 \mathrm{~Hz}, 1 \mathrm{H}), 7.46-7.40(\mathrm{~m}, 2 \mathrm{H}), 7.39-7.32(\mathrm{~m}$, 1H), 7.31-7.26 (m, 2H), 7.20-7.17 (m, 2H), $7.01(\mathrm{~s}, 1 \mathrm{H}), 2.01$ (s, 3H).

${ }^{13}$ C-NMR $\left(126 \mathrm{MHz}, \mathrm{CDCl}_{3}\right): \delta=168.1\left(\mathrm{C}_{\mathrm{q}}\right), 136.5\left(\mathrm{C}_{\mathrm{q}}\right), 134.4\left(\mathrm{C}_{\mathrm{q}}\right), 134.0\left(\mathrm{C}_{\mathrm{q}}\right), 131.3\left(\mathrm{C}_{\mathrm{q}}\right)$, $130.5(\mathrm{CH}), 129.9(\mathrm{CH}), 129.1(\mathrm{CH}), 128.6(\mathrm{CH}), 124.6(\mathrm{CH}), 122.2(\mathrm{CH}), 24.6\left(\mathrm{CH}_{3}\right)$.

IR (ATR): 3247, 3031, 2924, 2854, 1635, 1527, 1369, 1283, 1086, $828 \mathrm{~cm}^{-1}$

MS (EI) $m / z$ (relative intensity): 245 ([M+] 35), 203 (100), 167 (43), 139 (12), 84 (17), 43 (36).

HR-MS (EI) $m / z$ for $\mathrm{C}_{14} \mathrm{H}_{12} \mathrm{ClNO}\left[\mathbf{M}^{+}\right]$

calcd.: 245.0607 .

found: 245.0599 .

The analytical data are in accordance with those reported in the literature. ${ }^{[172]}$ 


\section{Synthesis of $N$-(3',4',5'-Trifluoro-[1,1'-biphenyl]-2-yl)acetamide (33ah)}

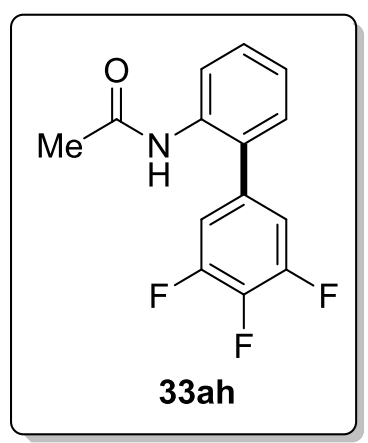

The general procedure A was followed using $\mathbf{3 0 a}(135 \mathrm{mg}, 1.00 \mathrm{mmol})$ and (3,4,5-trifluorophenyl)boronic acid (73h) (264 mg, $1.50 \mathrm{mmol}$ ). Purification by column chromatography ( $n$-hexane/EtOAc: $7 / 3)$ yielded 33ah $(180 \mathrm{mg}, 68 \%)$ as a colorless solid.

M. p.: $140-141^{\circ} \mathrm{C}$.

${ }^{1} \mathbf{H}-\mathbf{N M R}\left(300 \mathrm{MHz}, \mathrm{CDCl}_{3}\right): \delta=8.08(\mathrm{~d}, J=8.1 \mathrm{~Hz}, 1 \mathrm{H}), 7.40(\mathrm{ddd}, J=8.5,5.9,3.1 \mathrm{~Hz}$, 1H), 7.24-7.17 (m, 2H), 7.06-6.97 (m, 2H), 6.93 (s, 1H), 2.07 (s, 3H).

${ }^{13}$ C-NMR $\left(126 \mathrm{MHz}, \mathrm{CDCl}_{3}\right): \delta=168.1\left(\mathrm{C}_{\mathrm{q}}\right), 151.4\left(\mathrm{C}_{\mathrm{q}}, J_{\mathrm{C}-\mathrm{F}}=251.6,10.0,4.2 \mathrm{~Hz}\right), 139.5$ $\left(\mathrm{C}_{\mathrm{q}}, J_{\mathrm{C}-\mathrm{F}}=253.1,15.0 \mathrm{~Hz}\right), 134.6\left(\mathrm{C}_{\mathrm{q}}\right), 134.5\left(\mathrm{C}_{\mathrm{q}}\right), 130.5\left(\mathrm{C}_{\mathrm{q}}\right), 129.8(\mathrm{CH}), 129.5(\mathrm{CH}), 125.1$ $(\mathrm{CH}), 123.3(\mathrm{CH}), 113.5\left(\mathrm{CH}, J_{\mathrm{C}-\mathrm{F}}=16.1,5.4 \mathrm{~Hz}\right), 24.3\left(\mathrm{CH}_{3}\right)$.

${ }^{19}$ F-NMR $\left(282 \mathrm{MHz}, \mathrm{CDCl}_{3}\right): \delta=-(132.8-133.0)(\mathrm{m}),-161.0\left(\mathrm{tt}, J_{\mathrm{C}-\mathrm{F}}=20.6,6.5 \mathrm{~Hz}\right)$.

IR (ATR): 3263, 3040, 2934, 2864, 1660, 1526, 1483, 1359, 872, $762 \mathrm{~cm}^{-1}$.

MS (EI) $m / z$ (relative intensity): 265 ([M+ $]$ 29), 223 (100), 203 (16), 175 (5), 169 (5), 84 (6), $43(41)$.

HR-MS (EI) $m / z$ for $\mathrm{C}_{14} \mathrm{H}_{10} \mathrm{~F}_{3} \mathrm{NO}\left[\mathrm{M}^{+}\right]$ calcd.: 265.0714 . found: 265.0718 . 


\section{Synthesis of $N$-(3',4'-Dichloro-5-fluoro-[1,1'-biphenyl]-2-yl)acetamide (33qi)}

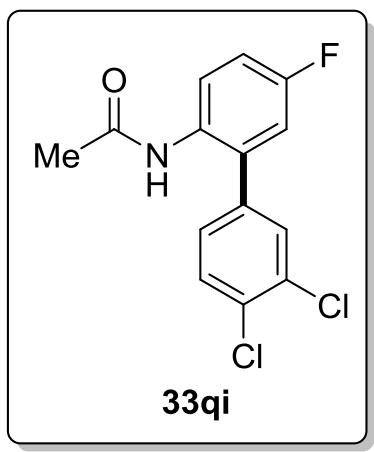

The general procedure A was followed using $\mathbf{3 0 q}(153 \mathrm{mg}, 1.00 \mathrm{mmol})$ and (3,4-dichlorophenyl)boronic acid (73i) $(286 \mathrm{mg}, 1.50 \mathrm{mmol})$. Purification by column chromatography (n-hexane/EtOAc: 6/4) yielded 33qi (188 mg, 63\%) as a colorless solid.

M. p.: $146-148^{\circ} \mathrm{C}$.

${ }^{1} \mathbf{H}-\mathbf{N M R}\left(300 \mathrm{MHz}, \mathrm{CDCl}_{3}\right): \delta=8.02-7.94(\mathrm{~m}, 1 \mathrm{H}), 7.53(\mathrm{~d}, J=8.2 \mathrm{~Hz}, 1 \mathrm{H}), 7.44(\mathrm{~d}$, $J=2.0 \mathrm{~Hz}, 1 \mathrm{H}), 7.18(\mathrm{dd}, J=8.2,2.1 \mathrm{~Hz}, 1 \mathrm{H}), 7.12-7.01(\mathrm{~m}, 1 \mathrm{H}), 6.96-6.93(\mathrm{~m}, 2 \mathrm{H}), 2.02$ $(\mathrm{s}, 3 \mathrm{H})$

${ }^{13}$ C-NMR $\left(75 \mathrm{MHz}, \mathrm{CDCl}_{3}\right): \delta=168.5\left(\mathrm{C}_{\mathrm{q}}\right), 159.5\left(\mathrm{C}_{\mathrm{q}}, \quad J_{\mathrm{C}-\mathrm{F}}=246.4 \mathrm{~Hz}\right), 137.2\left(\mathrm{C}_{\mathrm{q}}\right.$, $\left.J_{\mathrm{C}-\mathrm{F}}=1.6 \mathrm{~Hz}\right), 133.3\left(\mathrm{C}_{\mathrm{q}}\right), 133.0\left(\mathrm{C}_{\mathrm{q}}, J_{\mathrm{C}-\mathrm{F}}=7.6 \mathrm{~Hz}\right), 132.8\left(\mathrm{C}_{\mathrm{q}}\right), 131.0(\mathrm{CH}), 130.9(\mathrm{CH})$, $130.4\left(\mathrm{C}_{\mathrm{q}}, J_{\mathrm{C}-\mathrm{F}}=2.7 \mathrm{~Hz}\right), 128.2(\mathrm{CH}), 125.4\left(\mathrm{CH}, J_{\mathrm{C}-\mathrm{F}}=8.0 \mathrm{~Hz}\right), 116.5\left(\mathrm{CH}, J_{\mathrm{C}-\mathrm{F}}=23.2 \mathrm{~Hz}\right)$, $115.7\left(\mathrm{CH}, J_{\mathrm{C}-\mathrm{F}}=21.9 \mathrm{~Hz}\right), 24.2\left(\mathrm{CH}_{3}\right)$.

${ }^{19}$ F-NMR $\left(282 \mathrm{MHz}, \mathrm{CDCl}_{3}\right): \delta=-116.6(\mathrm{~s})$.

IR (ATR): 3242, 3190, 1652, 1529, 1472, 1371, 1183, 863, 702, $685 \mathrm{~cm}^{-1}$.

MS (EI) $m / z$ (relative intensity): 297 ([M+ $\left.\mathrm{M}^{+}\right]$48), 255 (100), 219 (40), 185 (52), 157 (17), 43 (60).

HR-MS (EI) $m / z$ for $\mathrm{C}_{14} \mathrm{H}_{10} \mathrm{Cl}_{2} \mathrm{FNO}\left[\mathrm{M}^{+}\right]$

calcd.: 297.0123 .

found: 297.0128

The analytical data are in accordance with those reported in the literature. ${ }^{[32]}$ 


\section{Synthesis of $N$-(4,4'-Dimethyl-[1,1'-biphenyl]-2-yl)acetamide (33ib)}

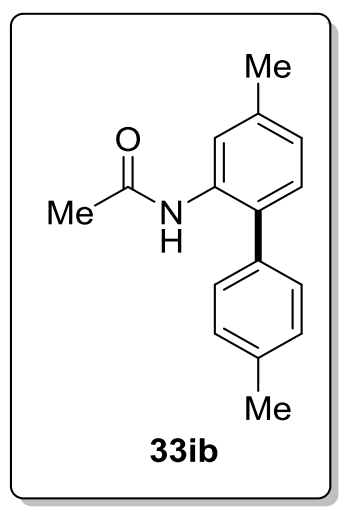

The general procedure B was followed using 30i $(149 \mathrm{mg}, 1.00 \mathrm{mmol})$ and hydroxydip-tolylborane (76b) $(315 \mathrm{mg}, 1.50 \mathrm{mmol})$. Purification by column chromatography (n-hexane/EtOAc: $7 / 3$ ) yielded 33ib (146 mg, 61\%) as a colorless solid.

M. p.: $120-121^{\circ} \mathrm{C}$.

${ }^{1} \mathbf{H}-\mathbf{N M R}\left(500 \mathrm{MHz}, \mathrm{CDCl}_{3}\right): \delta=8.06(\mathrm{~s}, 1 \mathrm{H}), 7.28-7.20(\mathrm{~m}, 4 \mathrm{H}), 7.15(\mathrm{~s}, 1 \mathrm{H}), 7.10(\mathrm{~d}$, $J=7.7 \mathrm{~Hz}, 1 \mathrm{H}), 6.96(\mathrm{~d}, J=7.7 \mathrm{~Hz}, 1 \mathrm{H}), 2.40$ (s, 3H), 2.38 (s, 3H), 1.99 (s, 3H).

${ }^{13}$ C-NMR $\left(126 \mathrm{MHz}, \mathrm{CDCl}_{3}\right): \delta=168.1\left(\mathrm{C}_{\mathrm{q}}\right), 138.1\left(\mathrm{C}_{\mathrm{q}}\right), 137.4\left(\mathrm{C}_{\mathrm{q}}\right), 135.1\left(\mathrm{C}_{\mathrm{q}}\right), 134.4\left(\mathrm{C}_{\mathrm{q}}\right)$, $129.8(\mathrm{CH}), 129.6(\mathrm{CH}), 129.3\left(\mathrm{C}_{\mathrm{q}}\right), 129.1(\mathrm{CH}), 125.1(\mathrm{CH}), 122.1(\mathrm{CH}), 24.5\left(\mathrm{CH}_{3}\right), 21.4$ $\left(\mathrm{CH}_{3}\right), 21.1\left(\mathrm{CH}_{3}\right)$.

IR (ATR): 3621, 3304, 3274, 1663, 1538, 1479, 1291, 812, 608, $530 \mathrm{~cm}^{-1}$.

MS (EI) $m / z$ (relative intensity): 239 ([M $\left.\mathrm{M}^{+}\right]$76), 197 (100), 181 (29), 43 (31).

HR-MS (EI) $m / z$ for $\mathrm{C}_{16} \mathrm{H}_{17} \mathrm{NO}\left[\mathrm{M}^{+}\right]$

calcd.: 239.1310.

found: 239.1311. 


\section{Synthesis of $N$-(4-Methoxy-4'-methyl-[1,1'-biphenyl]-2-yl)acetamide (33mb)}

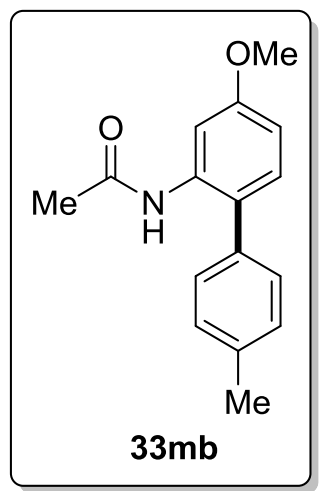

The general procedure B was followed using 30m (165 mg, $1.00 \mathrm{mmol})$ and hydroxydip-tolylborane (76b) $(315 \mathrm{mg}, 1.50 \mathrm{mmol})$. Purification by column chromatography ( $n$-hexane/EtOAc: $7 / 3$ ) yielded 33mb (163 mg, 64\%) as a colorless solid.

M. p.: $82-83{ }^{\circ} \mathrm{C}$.

${ }^{1} \mathbf{H}-\mathbf{N M R}\left(500 \mathrm{MHz}, \mathrm{CDCl}_{3}\right): \delta=7.97(\mathrm{~s}, 1 \mathrm{H}), 7.28-7.18(\mathrm{~m}, 5 \mathrm{H}), 7.10(\mathrm{~d}, J=8.4 \mathrm{~Hz}, 1 \mathrm{H})$, $6.69(\mathrm{dd}, J=8.6,2.7 \mathrm{~Hz}, 1 \mathrm{H}), 3.82(\mathrm{~s}, 3 \mathrm{H}), 2.39$ (s, 3H), 2.00 (s, 3H).

${ }^{13}$ C-NMR $\left(126 \mathrm{MHz}, \mathrm{CDCl}_{3}\right): \delta=168.1\left(\mathrm{C}_{\mathrm{q}}\right), 159.4\left(\mathrm{C}_{\mathrm{q}}\right), 137.4\left(\mathrm{C}_{\mathrm{q}}\right), 135.7\left(\mathrm{C}_{\mathrm{q}}\right), 134.9\left(\mathrm{C}_{\mathrm{q}}\right)$, $130.6(\mathrm{CH}), 129.7(\mathrm{CH}), 129.2(\mathrm{CH}), 124.2\left(\mathrm{C}_{\mathrm{q}}\right), 110.4(\mathrm{CH}), 106.2(\mathrm{CH}), 55.4\left(\mathrm{CH}_{3}\right), 24.7$ $\left(\mathrm{CH}_{3}\right), 21.1\left(\mathrm{CH}_{3}\right)$.

IR (ATR): 3330, 2965, 1668, 1581, 1475, 1419, 1305, 1235, 1041, $803 \mathrm{~cm}^{-1}$.

MS (EI) $m / z$ (relative intensity): 255 ([M+ $]$ 77), 213 (100), 170 (32), 43 (29).

HR-MS (EI) $m / z$ for $\mathrm{C}_{16} \mathrm{H}_{17} \mathrm{NO}_{2}\left[\mathbf{M}^{+}\right]$ calcd.: 255.1259 . found: 255.1257 . 


\section{Synthesis of $N$-(4',5-Dimethyl-[1,1'-biphenyl]-2-yl)acetamide (33hb)}

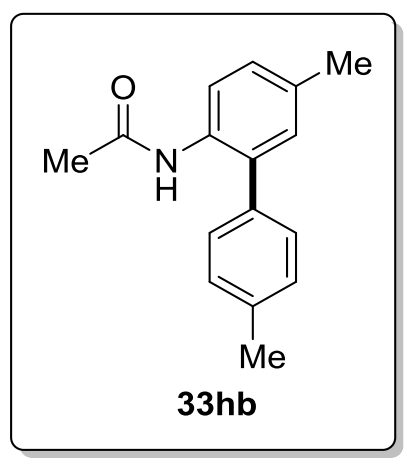

The general procedure B was followed using 30h $(149 \mathrm{mg}, 1.00 \mathrm{mmol})$ and hydroxydip-tolylborane (76b) (315 mg, $1.50 \mathrm{mmol})$. Purification by column chromatography ( $n$-hexane/EtOAc: $7 / 3$ ) yielded $\mathbf{3 3 h b}(151 \mathrm{mg}, 63 \%)$ as a colorless solid.

The general procedure $\mathbf{C}$ was followed using $\mathbf{3 0 h}(74.6 \mathrm{mg}, 0.50 \mathrm{mmol})$ and potassium p-tolyltrifluoroborate (77b) (297 mg, $1.50 \mathrm{mmol}$ ). Purification by column chromatography ( $n$-hexane/EtOAc: $7 / 3$ ) yielded 33hb (66 mg, 55\%) as a colorless solid.

M. p.: $97-98^{\circ} \mathrm{C}$.

${ }^{1} \mathbf{H}-\mathbf{N M R}\left(500 \mathrm{MHz}, \mathrm{CDCl}_{3}\right): \delta=8.06(\mathrm{~d}, J=8.4 \mathrm{~Hz}, 1 \mathrm{H}), 7.27-7.21(\mathrm{~m}, 4 \mathrm{H}), 7.13$ (dd, $J=8.4,2.1 \mathrm{~Hz}, 1 \mathrm{H}), 7.09$ (s, 1H), $7.03(\mathrm{~s}, 1 \mathrm{H}), 2.40$ (s, 3H), 2.32 (s, 3H), 1.99 (s, 3H).

${ }^{13}$ C-NMR $\left(126 \mathrm{MHz}, \mathrm{CDCl}_{3}\right): \delta=168.1\left(\mathrm{C}_{\mathrm{q}}\right), 137.6\left(\mathrm{C}_{\mathrm{q}}\right), 135.3\left(\mathrm{C}_{\mathrm{q}}\right), 133.9\left(\mathrm{C}_{\mathrm{q}}\right), 132.3\left(\mathrm{C}_{\mathrm{q}}\right)$, $132.1\left(\mathrm{C}_{\mathrm{q}}\right), 130.6(\mathrm{CH}), 129.6(\mathrm{CH}), 129.0(\mathrm{CH}), 128.7(\mathrm{CH}), 121.8(\mathrm{CH}), 24.4\left(\mathrm{CH}_{3}\right), 21.1$ $\left(\mathrm{CH}_{3}\right), 20.8\left(\mathrm{CH}_{3}\right)$.

IR (ATR): 3365, 3025, 2922, 2865, 1673, 1509, 1290, 815, 731, $667 \mathrm{~cm}^{-1}$.

MS (EI) $m / z$ (relative intensity): 239 ([M+ $\left.\mathrm{M}^{+}\right]$63), 197 (100), 180 (39), 43 (29).

HR-MS (EI) $m / z$ for $\mathrm{C}_{16} \mathrm{H}_{17} \mathrm{NO}\left[\mathbf{M}^{+}\right]$ calcd.: 239.1310 . found: 239.1312 . 


\section{Synthesis of $N$-(5-Methoxy-4'-methyl-[1,1'-biphenyl]-2-yl)acetamide (33lb)}

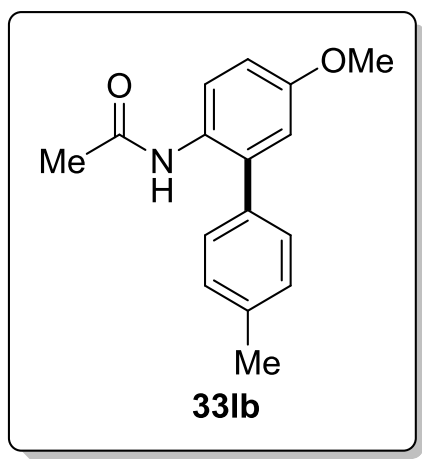

The general procedure B was followed using $301(165 \mathrm{mg}, 1.00 \mathrm{mmol})$ and hydroxydip-tolylborane (76b) $(315 \mathrm{mg}, 1.50 \mathrm{mmol})$. Purification by column chromatography ( $n$-hexane/EtOAc: 7/3) yielded 33lb (156 mg, 61\%) as a colorless solid.

The general procedure $\mathbf{C}$ was followed using $301(82.6 \mathrm{mg}, 0.50 \mathrm{mmol})$ and potassium p-tolyltrifluoroborate (77b) $(297 \mathrm{mg}, 1.50 \mathrm{mmol})$. Purification by column chromatography (n-hexane/EtOAc: 7/3) yielded 33lb (72 mg, 56\%) as a colorless solid.

M. p.: $109-110{ }^{\circ} \mathrm{C}$.

${ }^{1} \mathbf{H}-\mathbf{N M R}\left(500 \mathrm{MHz}, \mathrm{CDCl}_{3}\right): \delta=7.97(\mathrm{~d}, J=8.9 \mathrm{~Hz}, 1 \mathrm{H}), 7.27-7.20(\mathrm{~m}, 4 \mathrm{H}), 7.00(\mathrm{~s}, 1 \mathrm{H})$, $6.86(\mathrm{dd}, J=8.9,3.0 \mathrm{~Hz}, 1 \mathrm{H}), 6.77(\mathrm{~d}, J=3.0 \mathrm{~Hz}, 1 \mathrm{H}), 3.77$ (s, 3H), 2.39 (s, 3H), 1.97 (s, $3 \mathrm{H})$.

${ }^{13}$ C-NMR $\left(126 \mathrm{MHz}, \mathrm{CDCl}_{3}\right): \delta=168.3\left(\mathrm{C}_{\mathrm{q}}\right), 156.3\left(\mathrm{C}_{\mathrm{q}}\right), 137.7\left(\mathrm{C}_{\mathrm{q}}\right), 135.2\left(\mathrm{C}_{\mathrm{q}}\right), 134.6\left(\mathrm{C}_{\mathrm{q}}\right)$, $129.6(\mathrm{CH}), 128.8(\mathrm{CH}), 127.8\left(\mathrm{C}_{\mathrm{q}}\right), 124.1(\mathrm{CH}), 115.4(\mathrm{CH}), 113.1(\mathrm{CH}), 55.4\left(\mathrm{CH}_{3}\right), 24.1$ $\left(\mathrm{CH}_{3}\right), 21.1\left(\mathrm{CH}_{3}\right)$.

IR (ATR): 3269, 3022, 2971, 2921, 1660, 1520, 1267, 1176, 1031, $801 \mathrm{~cm}^{-1}$.

MS (EI) $m / z$ (relative intensity): 255 ([ $\left.\mathrm{M}^{+}\right]$86), 213 (89), 198 (100), 43 (19).

HR-MS (EI) $m / z$ for $\mathrm{C}_{16} \mathrm{H}_{17} \mathrm{NO}_{2}\left[\mathbf{M}^{+}\right]$ calcd.: 255.1259 . found: 255.1263 . 
Synthesis of Methyl (E)-2'-(phenyldiazenyl)-[1,1'-biphenyl]-4-carboxylate (83ba)

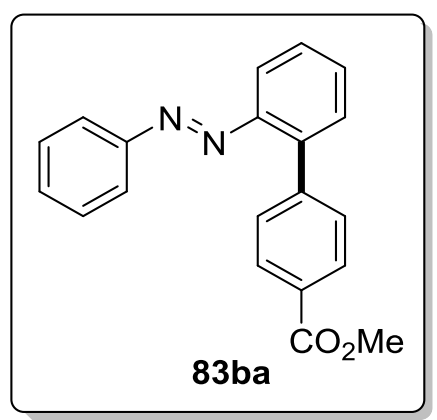

The general procedure D was followed using 13b $(182 \mathrm{mg}, 1.00 \mathrm{mmol})$ and methyl 4-bromobenzoate (52a) $(108 \mathrm{mg}, 0.50 \mathrm{mmol})$. Purification by column chromatography (n-hexane/ $\mathrm{CH}_{2} \mathrm{Cl}_{2}: 7 / 3$ ) yielded $\mathbf{8 3 b a}(93 \mathrm{mg}, 59 \%)$ as an orange solid.

M. p.: $128-129^{\circ} \mathrm{C}$.

${ }^{1} \mathbf{H}-\mathbf{N M R}\left(\mathrm{CDCl}_{3}, 500 \mathrm{MHz}\right): \delta=8.09(\mathrm{~d}, J=8.6 \mathrm{~Hz}, 2 \mathrm{H}), 7.80-7.72(\mathrm{~m}, 3 \mathrm{H}), 7.57-7.52(\mathrm{~m}$, 4H), 7.51-7.42 (m, 4H), $3.94(\mathrm{~s}, 3 \mathrm{H})$.

${ }^{13}$ C-NMR $\left(\mathrm{CDCl}_{3}, 126 \mathrm{MHz}\right): \delta=167.2\left(\mathrm{C}_{\mathrm{q}}\right), 152.7\left(\mathrm{C}_{\mathrm{q}}\right), 149.6\left(\mathrm{C}_{\mathrm{q}}\right), 143.7\left(\mathrm{C}_{\mathrm{q}}\right), 140.2\left(\mathrm{C}_{\mathrm{q}}\right)$, $131.1(\mathrm{CH}), 130.9(\mathrm{CH}), 130.9(\mathrm{CH}), 130.7(\mathrm{CH}), 129.1(\mathrm{CH}), 128.9(\mathrm{CH}), 128.8\left(\mathrm{C}_{\mathrm{q}}\right), 128.7$ $(\mathrm{CH}), 123.3(\mathrm{CH}), 116.0(\mathrm{CH}), 52.1\left(\mathrm{CH}_{3}\right)$.

IR (ATR): 3071, 2947, 2920, 2848, 1721, 1437, 1273, 1103, 774, 736, 686, $541 \mathrm{~cm}^{-1}$.

MS (EI) m/z (relative intensity): 316 ([M $\left.\mathrm{M}^{+}\right]$58), 301 (100), 257 (40), 211 (44), 152 (91), 77 (94).

HR-MS (EI) $m / z$ for $\mathrm{C}_{20} \mathrm{H}_{16} \mathrm{~N}_{2} \mathrm{O}_{2}\left[\mathbf{M}^{+}\right]$

calcd.: 316.1212 .

found: 316.1205 . 


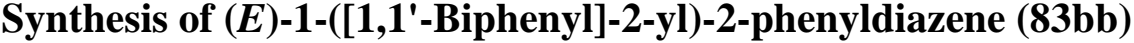

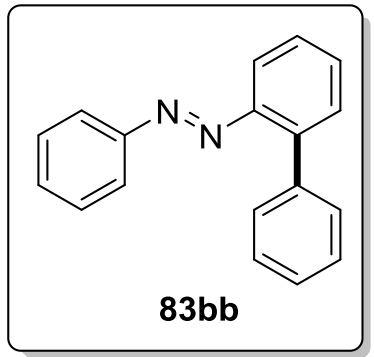

The general procedure $\mathbf{D}$ was followed using $\mathbf{1 3 b}(182 \mathrm{mg}, 1.00 \mathrm{mmol})$ and bromobenzene (52b) (79 mg, $0.50 \mathrm{mmol})$. Purification by column chromatography ( $n$-hexane/EtOAc/NEt 3 : $88 / 6 / 6)$ yielded $\mathbf{8 3 b b}(68 \mathrm{mg}, 53 \%)$ as an orange viscous oil.

${ }^{1} \mathbf{H}-\mathbf{N M R}\left(\mathrm{CDCl}_{3}, 300 \mathrm{MHz}\right): \delta=7.81-7.75(\mathrm{~m}, 2 \mathrm{H}), 7.62-7.35(\mathrm{~m}, 12 \mathrm{H})$.

${ }^{13} \mathrm{C}-\mathrm{NMR}\left(\mathrm{CDCl}_{3}, 126 \mathrm{MHz}\right): \delta=152.9\left(\mathrm{C}_{\mathrm{q}}\right), 149.8\left(\mathrm{C}_{\mathrm{q}}\right), 141.2\left(\mathrm{C}_{\mathrm{q}}\right), 138.9\left(\mathrm{C}_{\mathrm{q}}\right), 131.1(\mathrm{CH})$, $131.0(\mathrm{CH}), 130.9(\mathrm{CH}), 130.8(\mathrm{CH}), 129.1(\mathrm{CH}), 128.1(\mathrm{CH}), 127.7(\mathrm{CH}), 127.3(\mathrm{CH}), 123.3$ $(\mathrm{CH}), 116.0(\mathrm{CH})$.

IR (ATR): 3058, 3030, 1470, 1149, 1008, 770, 730, 685, 535, $497 \mathrm{~cm}^{-1}$.

MS (EI) $m / z$ (relative intensity): 258 ([M+ $\left.{ }^{+}\right]$42), 152 (82), 84 (100), 77 (70).

HR-MS (EI) $m / z$ for $\mathrm{C}_{18} \mathrm{H}_{14} \mathrm{~N}_{2}\left[\mathbf{M}^{+}\right]$ calcd.: 258.1157 . found: 258.1152 . 
Synthesis of Methyl (E)-3'-methyl-2'-(o-tolyldiazenyl)-[1,1'-biphenyl]-4-carboxylate (83ca)

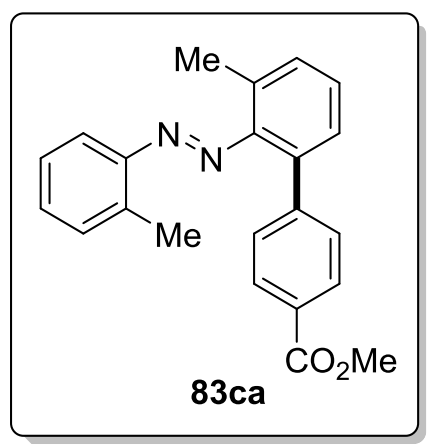

The general procedure D was followed using 13c $(210 \mathrm{mg}, 1.00 \mathrm{mmol})$ and methyl 4-bromobenzoate (52a) (108 $\mathrm{mg}, 0.50 \mathrm{mmol})$. Purification by column chromatography ( $n$-hexane/ $\mathrm{CH}_{2} \mathrm{Cl}_{2}: 7 / 3$ ) yielded 83ca $(103 \mathrm{mg}, 60 \%)$ as an orange solid.

M. p.: $123-124^{\circ} \mathrm{C}$.

${ }^{1} \mathbf{H}-\mathbf{N M R}\left(\mathrm{CDCl}_{3}, 500 \mathrm{MHz}\right): \delta=7.97(\mathrm{~d}, J=8.1 \mathrm{~Hz}, 2 \mathrm{H}), 7.38-7.26(\mathrm{~m}, 9 \mathrm{H}), 3.92(\mathrm{~s}, 3 \mathrm{H})$, $2.47(\mathrm{~s}, 3 \mathrm{H}), 2.28(\mathrm{~s}, 3 \mathrm{H})$.

${ }^{13} \mathrm{C}-\mathrm{NMR}\left(\mathrm{CDCl}_{3}, 126 \mathrm{MHz}\right): \delta=167.1\left(\mathrm{C}_{\mathrm{q}}\right), 150.9\left(\mathrm{C}_{\mathrm{q}}\right), 150.7\left(\mathrm{C}_{\mathrm{q}}\right), 145.4\left(\mathrm{C}_{\mathrm{q}}\right), 138.5\left(\mathrm{C}_{\mathrm{q}}\right)$, $134.7\left(\mathrm{C}_{\mathrm{q}}\right), 131.3(\mathrm{CH}), 131.2(\mathrm{CH}), 131.1(\mathrm{CH}), 130.8\left(\mathrm{C}_{\mathrm{q}}\right), 130.1(\mathrm{CH}), 129.1(\mathrm{CH}), 128.9$ $(\mathrm{CH}), 128.1(\mathrm{CH}), 128.0\left(\mathrm{C}_{\mathrm{q}}\right), 126.3(\mathrm{CH}), 115.0(\mathrm{CH}), 52.0\left(\mathrm{CH}_{3}\right), 19.2\left(\mathrm{CH}_{3}\right), 17.1\left(\mathrm{CH}_{3}\right)$.

IR (ATR): 3059, 2951, 2923, 2844, 1719, 1608, 1398, 1272, 1179, 1101, 856, 766, 739, $712 \mathrm{~cm}^{-1}$.

MS (EI) $m / z$ (relative intensity): 344 ([ $\left.\mathrm{M}^{+}\right]$60), 329 (93), 285 (30), 225 (50), 165 (99), 91 (100), 65 (34).

HR-MS (EI) $m / z$ for $\mathrm{C}_{22} \mathrm{H}_{20} \mathrm{~N}_{2} \mathrm{O}_{2}\left[\mathrm{M}^{+}\right]$ calcd.: 344.1525 . found: 344.1526 . 
Synthesis of (E)-1-\{3'-Methyl-2'-(o-tolyldiazenyl)-[1,1'-biphenyl]-4-yl\}ethan-1-one (83cc)

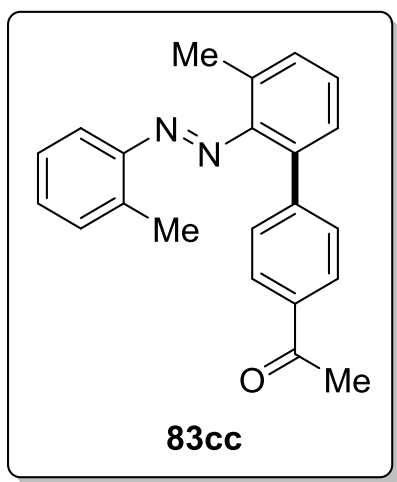

The general procedure $\mathbf{D}$ was followed using $13 \mathrm{c}(210 \mathrm{mg}, 1.00 \mathrm{mmol})$ and 1-(4-bromophenyl)ethan-1-one $\quad \mathbf{( 5 2 c )} \quad(100 \mathrm{mg}, \quad 0.50 \mathrm{mmol})$. Purification by column chromatography ( $n$-hexane/ $\mathrm{CH}_{2} \mathrm{Cl}_{2}: 7 / 3$ ) yielded 83cc $(87 \mathrm{mg}, 53 \%)$ as an orange solid.

M. p.: $125-126^{\circ} \mathrm{C}$.

${ }^{1} \mathbf{H}-\mathbf{N M R}\left(\mathrm{CDCl}_{3}, 300 \mathrm{MHz}\right): \delta=7.89(\mathrm{~d}, J=8.6 \mathrm{~Hz}, 2 \mathrm{H}), 7.37-7.29(\mathrm{~m}, 6 \mathrm{H}), 7.26(\mathrm{~d}$, $J=0.8 \mathrm{~Hz}, 2 \mathrm{H}), 7.24-7.15(\mathrm{~m}, 1 \mathrm{H}), 2.59$ (s, 3H), 2.46 (s, 3H), 2.27 (s, 3H).

${ }^{13}$ C-NMR $\left(\mathrm{CDCl}_{3}, 126 \mathrm{MHz}\right): \delta=198.0\left(\mathrm{C}_{\mathrm{q}}\right), 151.0\left(\mathrm{C}_{\mathrm{q}}\right), 150.8\left(\mathrm{C}_{\mathrm{q}}\right), 145.7\left(\mathrm{C}_{\mathrm{q}}\right), 138.5\left(\mathrm{C}_{\mathrm{q}}\right)$, $135.2\left(\mathrm{C}_{\mathrm{q}}\right), 134.7\left(\mathrm{C}_{\mathrm{q}}\right), 131.5(\mathrm{CH}), 131.4(\mathrm{CH}), 131.3(\mathrm{CH}), 130.9\left(\mathrm{C}_{\mathrm{q}}\right), 130.4(\mathrm{CH}), 128.9$ $(\mathrm{CH}), 128.2(\mathrm{CH}), 128.0(\mathrm{CH}), 126.4(\mathrm{CH}), 115.0(\mathrm{CH}), 26.5\left(\mathrm{CH}_{3}\right), 19.1\left(\mathrm{CH}_{3}\right), 17.0\left(\mathrm{CH}_{3}\right)$.

IR (ATR): 3054, 2961, 2923, 1679, 1603, 1356, 1264, 955, 766, $600 \mathrm{~cm}^{-1}$.

MS (EI) $m / z$ (relative intensity): 328 ([M+] 100), 285 (32), 209 (25), 165 (45), 91 (98), 65 (27), 43 (90).

HR-MS (EI) $m / z$ for $\mathrm{C}_{22} \mathrm{H}_{20} \mathrm{~N}_{2} \mathrm{O}\left[\mathrm{M}^{+}\right]$ calcd.: 328.1576 .

found: 328.1569 . 
Synthesis of Methyl (E)-5'-methyl-2'-(p-tolyldiazenyl)-[1,1'-biphenyl]-4-carboxylate (83da)

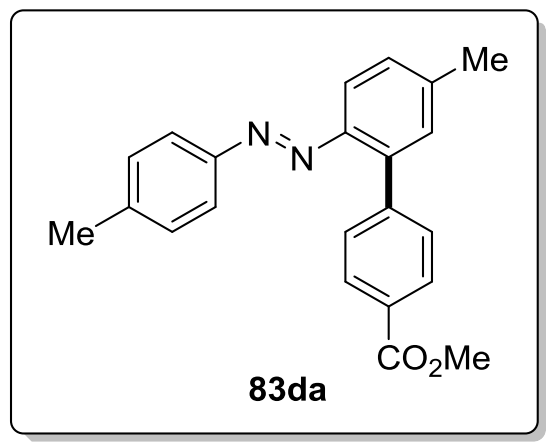

The general procedure D was followed using 13d (210 mg, $1.00 \mathrm{mmol})$ and methyl 4-bromobenzoate (52a) (108 $\mathrm{mg}, 0.50 \mathrm{mmol})$. Purification by column chromatography (n-hexane/ $\mathrm{CH}_{2} \mathrm{Cl}_{2}$ : 7/3) yielded $\mathbf{8 3 d a}(112 \mathrm{mg}, 65 \%$ ) as an orange solid.

M. p.: $138-139^{\circ} \mathrm{C}$.

${ }^{1} \mathbf{H}-\mathbf{N M R}\left(\mathrm{CDCl}_{3}, 500 \mathrm{MHz}\right): \delta=8.08(\mathrm{~d}, J=8.6 \mathrm{~Hz}, 2 \mathrm{H}), 7.71(\mathrm{~d}, J=8.2 \mathrm{~Hz}, 1 \mathrm{H}), 7.64(\mathrm{~d}$, $J=8.2 \mathrm{~Hz}, 2 \mathrm{H}), 7.54$ (d, $J=8.6 \mathrm{~Hz}, 2 \mathrm{H}), 7.37-7.35$ (m, 1H), 7.27 (ddq, $J=8.2,2.0,0.6 \mathrm{~Hz}$, 1H), 7.25-7.21 (m, 2H), $3.94(\mathrm{~s}, 3 \mathrm{H}), 2.46(\mathrm{~s}, 3 \mathrm{H}), 2.39(\mathrm{~s}, 3 \mathrm{H})$.

${ }^{13} \mathrm{C}-\mathrm{NMR}\left(\mathrm{CDCl}_{3}, 126 \mathrm{MHz}\right): \delta=167.2\left(\mathrm{C}_{\mathrm{q}}\right), 151.0\left(\mathrm{C}_{\mathrm{q}}\right), 147.6\left(\mathrm{C}_{\mathrm{q}}\right), 143.9\left(\mathrm{C}_{\mathrm{q}}\right), 141.4\left(\mathrm{C}_{\mathrm{q}}\right)$, $141.1\left(\mathrm{C}_{\mathrm{q}}\right), 140.0\left(\mathrm{C}_{\mathrm{q}}\right), 131.1(\mathrm{CH}), 130.8(\mathrm{CH}), 129.7(\mathrm{CH}), 129.5(\mathrm{CH}), 128.7(\mathrm{CH}), 128.6$ $\left(\mathrm{C}_{\mathrm{q}}\right), 123.1(\mathrm{CH}), 115.8(\mathrm{CH}), 52.1\left(\mathrm{CH}_{3}\right), 21.5\left(\mathrm{CH}_{3}\right), 21.5\left(\mathrm{CH}_{3}\right)$.

IR (ATR): 3029, 2948, 2921, 2844, 1721, 1599, 1437, 1274, 1149, 1112, 824, 702, 565, $385 \mathrm{~cm}^{-1}$.

MS (EI) $m / z$ (relative intensity): 344 ([ $\left.\mathrm{M}^{+}\right]$66), 329 (73), 285 (29), 225 (47), 165 (86), 91 (100), 65 (25).

HR-MS (ESI) $m / z$ for $\mathrm{C}_{22} \mathrm{H}_{21} \mathrm{~N}_{2} \mathrm{O}_{2}\left[\mathrm{M}+\mathrm{H}^{+}\right] \quad$ calcd.: 345.1603 . found: 345.1599 . 
Synthesis of Methyl (E)-4'-methyl-2'-(m-tolyldiazenyl)-[1,1'-biphenyl]-4-carboxylate (83aa)

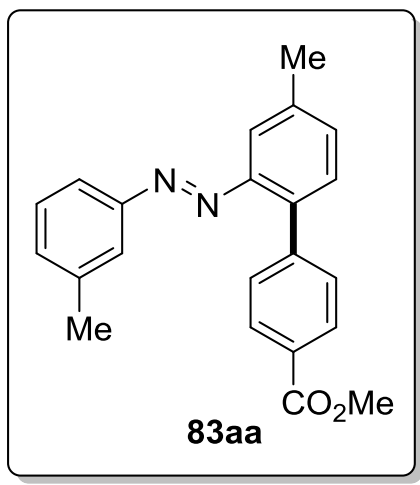

The general procedure D was followed using 13a $(210 \mathrm{mg}, 1.00 \mathrm{mmol})$ and methyl 4-bromobenzoate $\mathbf{( 5 2 a )}(108 \mathrm{mg}, 0.50 \mathrm{mmol})$. Purification by column chromatography ( $n$-hexane/ $\mathrm{CH}_{2} \mathrm{Cl}_{2}: 7 / 3$ ) yielded 83aa $(150 \mathrm{mg}, 87 \%$ ) as an orange solid.

M. p.: $136-137^{\circ} \mathrm{C}$.

${ }^{1} \mathbf{H}-\mathbf{N M R}\left(\mathrm{CDCl}_{3}, 300 \mathrm{MHz}\right): \delta=8.10(\mathrm{~d}, J=8.0 \mathrm{~Hz}, 2 \mathrm{H}), 7.64(\mathrm{~s}, 1 \mathrm{H}), 7.60-7.53(\mathrm{~m}, 4 \mathrm{H})$, $7.49(\mathrm{~d}, J=7.8 \mathrm{~Hz}, 1 \mathrm{H}), 7.40-7.32(\mathrm{~m}, 2 \mathrm{H}), 7.30-7.24(\mathrm{~m}, 1 \mathrm{H}), 3.96(\mathrm{~s}, 3 \mathrm{H}), 2.48(\mathrm{~s}, 3 \mathrm{H})$, $2.42(\mathrm{~s}, 3 \mathrm{H})$.

${ }^{13}$ C-NMR $\left(\mathrm{CDCl}_{3}, 126 \mathrm{MHz}\right): \delta=167.0\left(\mathrm{C}_{\mathrm{q}}\right), 152.7\left(\mathrm{C}_{\mathrm{q}}\right), 149.3\left(\mathrm{C}_{\mathrm{q}}\right), 143.6\left(\mathrm{C}_{\mathrm{q}}\right), 138.8\left(\mathrm{C}_{\mathrm{q}}\right)$, $138.7\left(\mathrm{C}_{\mathrm{q}}\right), 137.1\left(\mathrm{C}_{\mathrm{q}}\right), 131.7(\mathrm{CH}), 131.5(\mathrm{CH}), 130.7(\mathrm{CH}), 130.4(\mathrm{CH}), 128.8(\mathrm{CH}), 128.7$ $(\mathrm{CH}), 128.5\left(\mathrm{C}_{\mathrm{q}}\right), 124.2(\mathrm{CH}), 119.8(\mathrm{CH}), 116.1(\mathrm{CH}), 52.1\left(\mathrm{CH}_{3}\right), 21.4\left(\mathrm{CH}_{3}\right), 21.3\left(\mathrm{CH}_{3}\right)$.

IR (ATR): 3030, 2951, 2914, 2850, 1721, 1606, 1438, 1279, 1106, 829, $790 \mathrm{~cm}^{-1}$.

MS (EI) $m / z$ (relative intensity): 344 ([M+] 60), 329 (80), 285 (38), 225 (43), 165 (87), 91 (100), 65 (25), 43 (22).

HR-MS (EI) $m / z$ for $\mathrm{C}_{22} \mathrm{H}_{20} \mathrm{~N}_{2} \mathrm{O}_{2}\left[\mathrm{M}^{+}\right]$ calcd.: 344.1525 . found: 344.1511 . 
Synthesis of Methyl $(E)-4$ '-ethyl-2'-\{(3-ethylphenyl)diazenyl $\}-[1,1 '$-biphenyl]-

4-carboxylate (83ea)

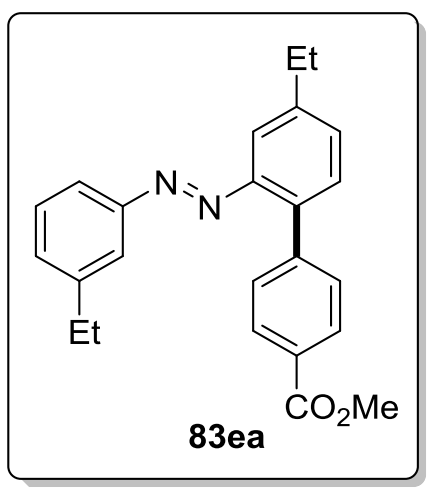

The general procedure $\mathbf{D}$ was followed using 13e $(238 \mathrm{mg}, 1.00 \mathrm{mmol})$ and methyl 4-bromobenzoate (52a) (108 $\mathrm{mg}, 0.50 \mathrm{mmol})$. Purification by column chromatography ( $n$-hexane/ $\mathrm{CH}_{2} \mathrm{Cl}_{2}: 7 / 3$ ) yielded 83ea $(155 \mathrm{mg}, 83 \%)$ as an orange solid.

M. p.: $81-82^{\circ} \mathrm{C}$.

${ }^{1} \mathbf{H}-\mathbf{N M R}\left(\mathrm{CDCl}_{3}, 500 \mathrm{MHz}\right): \delta=8.07(\mathrm{~d}, J=8.6 \mathrm{~Hz}, 2 \mathrm{H}), 7.68-7.65(\mathrm{~m}, 1 \mathrm{H}), 7.61-7.59(\mathrm{~m}$, 1H), 7.57-7.52 (m, 3H), 7.50 (dd, $J=7.9,0.5 \mathrm{~Hz}, 1 \mathrm{H}), 7.39$ (dd, $J=7.9,1.8 \mathrm{~Hz}, 1 \mathrm{H}), 7.35$ (t, $J=7.7 \mathrm{~Hz}, 1 \mathrm{H}), 7.29-7.26(\mathrm{~m}, 1 \mathrm{H}), 3.94(\mathrm{~s}, 3 \mathrm{H}), 2.77$ (q, $J=7.6 \mathrm{~Hz}, 2 \mathrm{H}), 2.71$ (q, $J=7.6 \mathrm{~Hz}$, $2 \mathrm{H}), 1.32(\mathrm{t}, J=7.6 \mathrm{~Hz}, 3 \mathrm{H}), 1.26(\mathrm{t}, J=7.6 \mathrm{~Hz}, 3 \mathrm{H})$.

${ }^{13} \mathrm{C}-\mathrm{NMR}\left(\mathrm{CDCl}_{3}, 126 \mathrm{MHz}\right): \delta=167.2\left(\mathrm{C}_{\mathrm{q}}\right), 153.0\left(\mathrm{C}_{\mathrm{q}}\right), 149.6\left(\mathrm{C}_{\mathrm{q}}\right), 145.3\left(\mathrm{C}_{\mathrm{q}}\right), 145.2\left(\mathrm{C}_{\mathrm{q}}\right)$, $143.8\left(\mathrm{C}_{\mathrm{q}}\right), 137.5\left(\mathrm{C}_{\mathrm{q}}\right), 130.9(\mathrm{CH}), 130.7(\mathrm{CH}), 130.6(\mathrm{CH}), 130.5(\mathrm{CH}), 129.0(\mathrm{CH}), 128.8$ $(\mathrm{CH}), 128.6\left(\mathrm{C}_{\mathrm{q}}\right), 123.4(\mathrm{CH}), 119.8(\mathrm{CH}), 115.0(\mathrm{CH}), 52.1\left(\mathrm{CH}_{3}\right), 28.7\left(\mathrm{CH}_{2}\right), 28.7\left(\mathrm{CH}_{2}\right)$, $15.4\left(\mathrm{CH}_{3}\right), 15.3\left(\mathrm{CH}_{3}\right)$.

IR (ATR): 2962, 2930, 2871, 1717, 1606, 1439, 1273, 1181, 1102, $691 \mathrm{~cm}^{-1}$.

MS (EI) $m / z$ (relative intensity): 372 ([M+ $\left.{ }^{+}\right]$89), 357 (100), 313 (45), 239 (61), 180 (35), 165 (75), 105 (91), 77 (32).

HR-MS (ESI) $m / z$ for $\mathrm{C}_{24} \mathrm{H}_{25} \mathrm{~N}_{2} \mathrm{O}_{2}\left[\mathrm{M}+\mathrm{H}^{+}\right] \quad$ calcd.: 373.1916 .

found: 373.1915 . 
Synthesis of Methyl (E)-4'-isopropyl-2'-\{(3-isopropylphenyl)diazenyl\}-[1,1'-biphenyl]4-carboxylate (83fa)

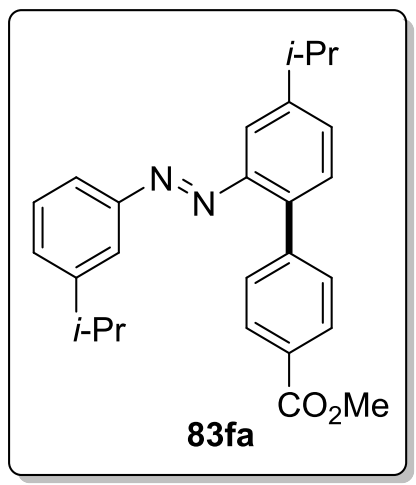

The general procedure D was followed using 13f $(266 \mathrm{mg}, 1.00 \mathrm{mmol})$ and methyl 4-bromobenzoate (52a) $(108 \mathrm{mg}, 0.50 \mathrm{mmol})$. Purification by column chromatography ( $n$-hexane/ $\mathrm{CH}_{2} \mathrm{Cl}_{2}: 7 / 3$ ) yielded $\mathbf{8 3 f a}(160 \mathrm{mg}, 80 \%)$ as an orange solid.

M. p.: $92-93^{\circ} \mathrm{C}$.

${ }^{1} \mathbf{H}-\mathbf{N M R}\left(\mathrm{CDCl}_{3}, 500 \mathrm{MHz}\right): \delta=8.07(\mathrm{~d}, J=8.5 \mathrm{~Hz}, 2 \mathrm{H}), 7.71(\mathrm{t}, J=1.8 \mathrm{~Hz}, 1 \mathrm{H}), 7.63(\mathrm{~d}$, $J=1.9 \mathrm{~Hz}, 1 \mathrm{H}), 7.56-7.50(\mathrm{~m}, 4 \mathrm{H}), 7.43(\mathrm{dd}, J=8.0,1.9 \mathrm{~Hz}, 1 \mathrm{H}), 7.35(\mathrm{t}, J=7.7 \mathrm{~Hz}, 1 \mathrm{H})$, $7.32-7.29(\mathrm{~m}, 1 \mathrm{H}), 3.93$ (s, 3H), 3.04 (sept, $J=6.9 \mathrm{~Hz}, 1 \mathrm{H}), 2.97$ (sep, $J=6.9 \mathrm{~Hz}, 1 \mathrm{H}), 1.33$ $(\mathrm{d}, J=6.9 \mathrm{~Hz}, 6 \mathrm{H}), 1.27(\mathrm{~d}, J=6.9 \mathrm{~Hz}, 6 \mathrm{H})$.

${ }^{13} \mathrm{C}-\mathrm{NMR}\left(\mathrm{CDCl}_{3}, 126 \mathrm{MHz}\right): \delta=167.2\left(\mathrm{C}_{\mathrm{q}}\right), 153.1\left(\mathrm{C}_{\mathrm{q}}\right), 150.0\left(\mathrm{C}_{\mathrm{q}}\right), 149.9\left(\mathrm{C}_{\mathrm{q}}\right), 149.5\left(\mathrm{C}_{\mathrm{q}}\right)$, $143.8\left(\mathrm{C}_{\mathrm{q}}\right), 137.7\left(\mathrm{C}_{\mathrm{q}}\right), 130.9(\mathrm{CH}), 130.6(\mathrm{CH}), 129.4(\mathrm{CH}), 129.1(\mathrm{CH}), 129.0(\mathrm{CH}), 128.8$ $(\mathrm{CH}), 128.6\left(\mathrm{C}_{\mathrm{q}}\right), 122.4(\mathrm{CH}), 119.6(\mathrm{CH}), 113.7(\mathrm{CH}), 52.1\left(\mathrm{CH}_{3}\right), 34.1(\mathrm{CH}), 34.0(\mathrm{CH})$, $23.9\left(\mathrm{CH}_{3}\right), 23.8\left(\mathrm{CH}_{3}\right)$.

IR (ATR): 2959, 2889, 2868, 1718, 1607, 1439, 1273, 1113, 858, 835, 797, $694 \mathrm{~cm}^{-1}$.

MS (EI) $m / z$ (relative intensity): 400 ([ $\left.\mathrm{M}^{+}\right]$96), 385 (100), 341 (41), 253 (45), 211 (47), 179 (43), 119 (78), 91 (42).

HR-MS (EI) $m / z$ for $\mathrm{C}_{26} \mathrm{H}_{28} \mathrm{~N}_{2} \mathrm{O}_{2}\left[\mathrm{M}^{+}\right]$

calcd.: 400.2151.

found: 400.2138 . 
Synthesis of Methyl (E)-4'-methoxy-2'-\{(3-methoxyphenyl)diazenyl\}-[1,1'-biphenyl]4-carboxylate (83ga)

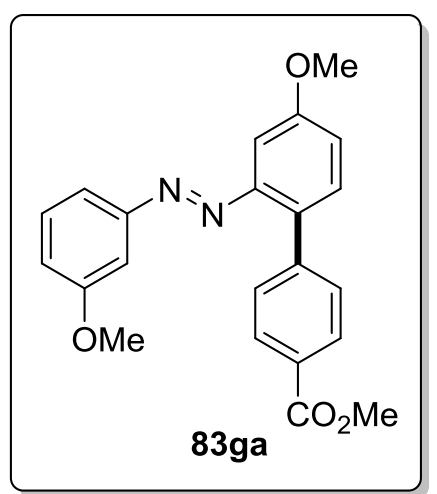

The general procedure D was followed using $\mathbf{1 3 g}(242 \mathrm{mg}, 1.00 \mathrm{mmol})$ and methyl 4-bromobenzoate (52a) (108 $\mathrm{mg}, 0.50 \mathrm{mmol})$. Purification by column chromatography ( $n$-hexane/ $\mathrm{CH}_{2} \mathrm{Cl}_{2}: 7 / 3$ ) yielded 83ga (139 $\mathrm{mg}, 74 \%$ ) as an orange solid.

M. p.: $145-146^{\circ} \mathrm{C}$.

${ }^{1} \mathbf{H}-\mathbf{N M R}\left(\mathrm{CDCl}_{3}, 500 \mathrm{MHz}\right): \delta=8.06(\mathrm{~d}, J=8.6 \mathrm{~Hz}, 2 \mathrm{H}), 7.53-7.48(\mathrm{~m}, 3 \mathrm{H}), 7.44$ (ddd, $J=7.8,1.7,1.0 \mathrm{~Hz}, 1 \mathrm{H}), 7.37(\mathrm{~d}, J=8.1 \mathrm{~Hz}, 1 \mathrm{H}), 7.35-7.33(\mathrm{~m}, 1 \mathrm{H}), 7.27(\mathrm{dd}, J=2.6$, $1.7 \mathrm{~Hz}, 1 \mathrm{H}), 7.13(\mathrm{dd}, J=8.5,2.7 \mathrm{~Hz}, 1 \mathrm{H}), 7.02-6.98(\mathrm{~m}, 1 \mathrm{H}), 3.93(\mathrm{~s}, 3 \mathrm{H}), 3.91(\mathrm{~s}, 3 \mathrm{H}), 3.78$ $(\mathrm{s}, 3 \mathrm{H})$.

${ }^{13} \mathrm{C}-\mathrm{NMR}\left(\mathrm{CDCl}_{3}, 126 \mathrm{MHz}\right): \delta=167.1\left(\mathrm{C}_{\mathrm{q}}\right), 160.3\left(\mathrm{C}_{\mathrm{q}}\right), 160.0\left(\mathrm{C}_{\mathrm{q}}\right), 153.9\left(\mathrm{C}_{\mathrm{q}}\right), 150.0\left(\mathrm{C}_{\mathrm{q}}\right)$, $143.5\left(\mathrm{C}_{\mathrm{q}}\right), 133.5\left(\mathrm{C}_{\mathrm{q}}\right), 131.6(\mathrm{CH}), 130.9(\mathrm{CH}), 129.8(\mathrm{CH}), 128.7(\mathrm{CH}), 128.4\left(\mathrm{C}_{\mathrm{q}}\right), 118.4$ $(\mathrm{CH}), 118.0(\mathrm{CH}), 117.4(\mathrm{CH}), 106.2(\mathrm{CH}), 99.3(\mathrm{CH}), 55.6\left(\mathrm{CH}_{3}\right), 55.3\left(\mathrm{CH}_{3}\right), 52.1\left(\mathrm{CH}_{3}\right)$.

IR (ATR): 2950, 2902, 2834, 1719, 1597, 1519, 1481, 1433, 1270, 1132, 1103, 1039, 887, $782,683 \mathrm{~cm}^{-1}$.

MS (EI) $m / z$ (relative intensity): 376 ([M+ $\left.{ }^{+}\right]$64), 361 (100), 317 (53), 241 (38), 182 (35), 139 (54), 107 (65), 77 (38).

HR-MS (ESI) $m / z$ for $\mathrm{C}_{22} \mathrm{H}_{21} \mathrm{~N}_{2} \mathrm{O}_{4}\left[\mathrm{M}+\mathrm{H}^{+}\right]$ calcd.: 377.1501 . found: 377.1491 . 
Synthesis of (E)-1-\{4'-Methoxy-2'-[(3-methoxyphenyl)diazenyl]-[1,1'-biphenyl]-

\section{4-yl\}ethan-1-one (83gc)}

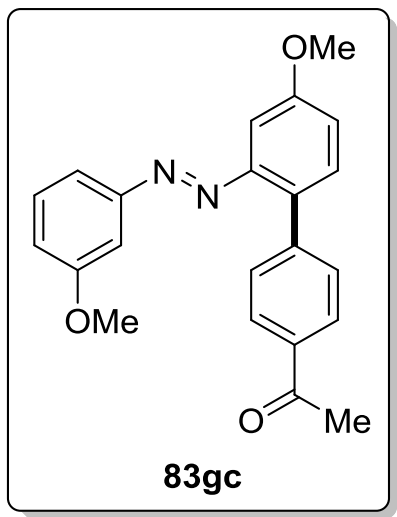

The general procedure D was followed using $\mathbf{1 3 g}(242 \mathrm{mg}, 1.00 \mathrm{mmol})$ and methyl 4-bromobenzoate $\mathbf{( 5 2 c )}(100 \mathrm{mg}, 0.50 \mathrm{mmol})$. Purification by column chromatography ( $n$-hexane/ $\mathrm{CH}_{2} \mathrm{Cl}_{2}: 7 / 3$ ) yielded 83gc (96 mg, 53\%) as an orange solid.

M. p.: $155-156^{\circ} \mathrm{C}$.

${ }^{1} \mathbf{H}-\mathbf{N M R}\left(\mathrm{CDCl}_{3}, 300 \mathrm{MHz}\right): \delta=7.98(\mathrm{~d}, J=8.5 \mathrm{~Hz}, 2 \mathrm{H}), 7.56-7.47$ (m, 3H), 7.44 (ddd, $J=7.8,1.4,1.3 \mathrm{~Hz}, 1 \mathrm{H}), 7.38(\mathrm{~d}, J=8.0 \mathrm{~Hz}, 1 \mathrm{H}), 7.34$ (d, $J=2.8 \mathrm{~Hz}, 1 \mathrm{H}), 7.29-7.23$ (m, 1H), 7.13 (dd, $J=8.6,2.7 \mathrm{~Hz}, 1 \mathrm{H}), 7.00$ (ddd, $J=8.0,2.7,1.2 \mathrm{~Hz}, 1 \mathrm{H}), 3.91$ (s, 3H), 3.78 (s, $3 \mathrm{H}), 2.63(\mathrm{~s}, 3 \mathrm{H})$.

${ }^{13}$ C-NMR $\left(\mathrm{CDCl}_{3}, 126 \mathrm{MHz}\right): \delta=198.1\left(\mathrm{C}_{\mathrm{q}}\right), 160.4\left(\mathrm{C}_{\mathrm{q}}\right), 160.2\left(\mathrm{C}_{\mathrm{q}}\right), 154.0\left(\mathrm{C}_{\mathrm{q}}\right), 150.2\left(\mathrm{C}_{\mathrm{q}}\right)$, $143.8\left(\mathrm{C}_{\mathrm{q}}\right), 135.4\left(\mathrm{C}_{\mathrm{q}}\right), 133.4\left(\mathrm{C}_{\mathrm{q}}\right), 131.6(\mathrm{CH}), 131.1(\mathrm{CH}), 129.9(\mathrm{CH}), 127.6(\mathrm{CH}), 118.5$ $(\mathrm{CH}), 118.0(\mathrm{CH}), 117.4(\mathrm{CH}), 106.4(\mathrm{CH}), 99.4(\mathrm{CH}), 55.6\left(\mathrm{CH}_{3}\right), 55.3\left(\mathrm{CH}_{3}\right), 26.6\left(\mathrm{CH}_{3}\right)$.

IR (ATR): 3068, 3005, 2961, 2940, 2915, 2834, 1673, 1604, 1513, 1269, 1132, 1040, 887, $819,782,634 \mathrm{~cm}^{-1}$.

MS (EI) $m / z$ (relative intensity): 360 ([M+] 100), 317 (57), 139 (38), 107 (53), 92 (24), 77 (30), 43 (54).

HR-MS (EI) $m / z$ for $\mathrm{C}_{22} \mathrm{H}_{20} \mathrm{~N}_{2} \mathrm{O}_{3}\left[\mathbf{M}^{+}\right]$ calcd.: 360.1474 . found: 360.1466 . 
Synthesis of $(E)-1-(4 '-C h l o r o-4-m e t h y l-[1,1 '-b i p h e n y l]-2-y l)-2-(m$-tolyl)diazene (83ad)

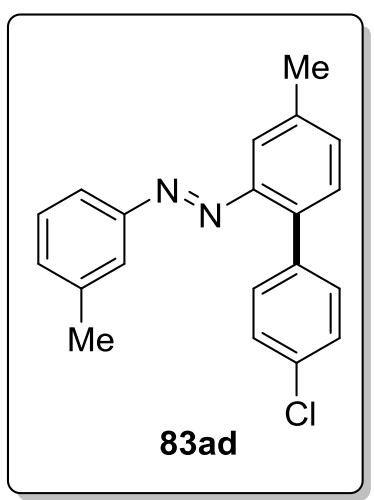

The general procedure D was followed using 13a $(210 \mathrm{mg}, 1.00 \mathrm{mmol})$ and 1-bromo-4chlorobenzene (52d) $(96 \mathrm{mg}, 0.50 \mathrm{mmol})$. Purification by column chromatography ( $n$-hexane/EtOAc/NEt 3 : 88/6/6) yielded 83ad (93 mg, 58\%) as an orange solid.

M. p.: $120-121^{\circ} \mathrm{C}$.

${ }^{1} \mathbf{H}-\mathbf{N M R}\left(\mathrm{CDCl}_{3}, 500 \mathrm{MHz}\right): \delta=7.73-7.69(\mathrm{~m}, 1 \mathrm{H}), 7.60(\mathrm{~s}, 1 \mathrm{H}), 7.56(\mathrm{~d}, J=7.9 \mathrm{~Hz}, 1 \mathrm{H})$, $7.53(\mathrm{~s}, 1 \mathrm{H}), 7.42(\mathrm{~d}, J=7.9 \mathrm{~Hz}, 1 \mathrm{H}), 7.38-7.36(\mathrm{~m}, 3 \mathrm{H}), 7.36-7.32(\mathrm{~m}, 2 \mathrm{H}), 7.29-7.25(\mathrm{~m}$, $1 \mathrm{H}), 2.45$ (s, 3H), $2.41(\mathrm{~s}, 3 \mathrm{H})$.

${ }^{13} \mathbf{C}-\mathrm{NMR}\left(\mathrm{CDCl}_{3}, 126 \mathrm{MHz}\right): \delta=152.9\left(\mathrm{C}_{\mathrm{q}}\right), 149.5\left(\mathrm{C}_{\mathrm{q}}\right), 139.0\left(\mathrm{C}_{\mathrm{q}}\right), 138.5\left(\mathrm{C}_{\mathrm{q}}\right), 137.3\left(\mathrm{C}_{\mathrm{q}}\right)$, $137.1\left(\mathrm{C}_{\mathrm{q}}\right), 133.2\left(\mathrm{C}_{\mathrm{q}}\right), 132.1(\mathrm{CH}), 131.8(\mathrm{CH}), 131.7(\mathrm{CH}), 130.4(\mathrm{CH}), 128.9(\mathrm{CH}), 127.7$ $(\mathrm{CH}), 124.2(\mathrm{CH}), 120.0(\mathrm{CH}), 116.2(\mathrm{CH}), 21.4\left(\mathrm{CH}_{3}\right), 21.2\left(\mathrm{CH}_{3}\right)$.

IR (ATR): 3049, 3028, 2949, 2920, 2859, 1596, 1479, 1092, 1005, 811, 788, 747, $687 \mathrm{~cm}^{-1}$.

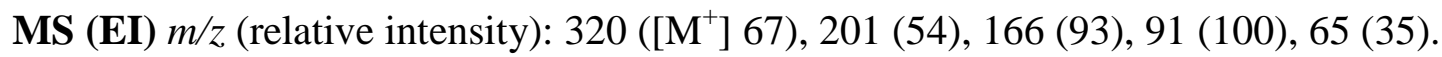

HR-MS (ESI) $m / z$ for $\mathrm{C}_{20} \mathrm{H}_{18} \mathrm{ClN}_{2}\left[\mathrm{M}+\mathrm{H}^{+}\right]$

calcd.: 321.1159 .

found: 321.1141. 
Synthesis of $(E)-N, N, 4^{\prime}$-Trimethyl-2'-(m-tolyldiazenyl)-[1,1'-biphenyl]-4-amine (83ae)

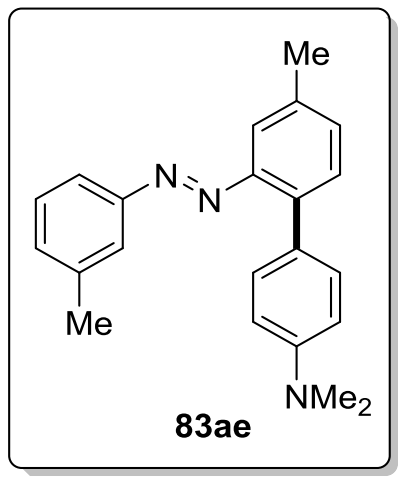

The general procedure D was followed using 13a $(210 \mathrm{mg}, 1.00 \mathrm{mmol})$ and 4-bromo- $N, N$ dimethylaniline (52e) $(100 \mathrm{mg}, 0.50 \mathrm{mmol})$. Purification by column chromatography ( $n$-hexane $/ \mathrm{CH}_{2} \mathrm{Cl}_{2}: 7 / 3$ ) yielded 83ae (92 $\mathrm{mg}, 56 \%$ ) as an orange solid.

M. p.: $124-125^{\circ} \mathrm{C}$.

${ }^{1} \mathbf{H}-\mathbf{N M R}\left(\mathrm{CDCl}_{3}, 500 \mathrm{MHz}\right): \delta=7.68(\mathrm{~s}, 1 \mathrm{H}), 7.65(\mathrm{~d}, J=7.3 \mathrm{~Hz}, 1 \mathrm{H}), 7.49(\mathrm{~d}, J=7.9 \mathrm{~Hz}$, 2H), 7.38-7.34 (m, 3H), 7.33-7.31 (m, 1H), $7.25(\mathrm{~d}, J=6.8 \mathrm{~Hz}, 1 \mathrm{H}), 6.80(\mathrm{~d}, J=8.7 \mathrm{~Hz}, 2 \mathrm{H})$, $3.00(\mathrm{~s}, 6 \mathrm{H}), 2.44(\mathrm{~s}, 3 \mathrm{H}), 2.42(\mathrm{~s}, 3 \mathrm{H})$.

${ }^{13} \mathrm{C}$-NMR $\left(\mathrm{CDCl}_{3}, 126 \mathrm{MHz}\right): \delta=153.1\left(\mathrm{C}_{\mathrm{q}}\right), 149.7\left(\mathrm{C}_{\mathrm{q}}\right), 149.6\left(\mathrm{C}_{\mathrm{q}}\right), 138.8\left(\mathrm{C}_{\mathrm{q}}\right), 138.2\left(\mathrm{C}_{\mathrm{q}}\right)$, $136.7\left(\mathrm{C}_{\mathrm{q}}\right), 131.8(\mathrm{CH}), 131.5(\mathrm{CH}), 131.3(\mathrm{CH}), 130.3(\mathrm{CH}), 128.8(\mathrm{CH}), 126.7\left(\mathrm{C}_{\mathrm{q}}\right), 124.0$ $(\mathrm{CH}), 120.2(\mathrm{CH}), 116.2(\mathrm{CH}), 111.8(\mathrm{CH}), 40.6\left(\mathrm{CH}_{3}\right), 21.4\left(\mathrm{CH}_{3}\right), 21.1\left(\mathrm{CH}_{3}\right)$.

IR (ATR): 2915, 2858, 2803, 1611, 1528, 1494, 1444, 1353, 1196, 806, 686, $532 \mathrm{~cm}^{-1}$.

MS (EI) m/z (relative intensity): 329 ([M+] 100), 285 (12), 210 (29), 167 (19), 91 (19), 65 (8).

HR-MS (EI) $m / z$ for $\mathrm{C}_{22} \mathrm{H}_{23} \mathrm{~N}_{3}\left[\mathbf{M}^{+}\right]$

calcd.: 329.1892 .

found: 329.1874 . 
Synthesis of (E)-1-(4'-Methoxy-4-methyl-[1,1'-biphenyl]-2-yl)-2-(m-tolyl)diazene (83af)

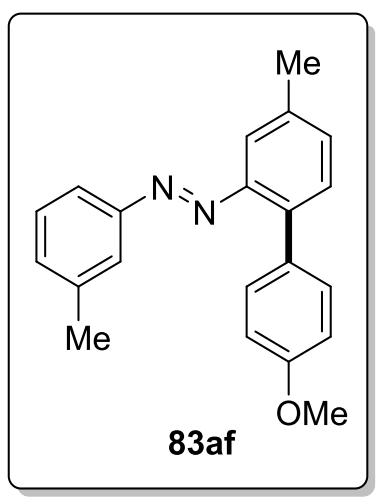

The general procedure D was followed using 13a $(210 \mathrm{mg}, 1.00 \mathrm{mmol})$ and 1-bromo-4methoxybenzene (52f) (94 mg, $0.50 \mathrm{mmol})$. Purification by column chromatography ( $n$-hexane/ $\mathrm{CH}_{2} \mathrm{Cl}_{2}: 7 / 3$ ) yielded 83af (106 mg, 67\%) as an orange solid.

M. p.: $121-122^{\circ} \mathrm{C}$.

${ }^{1}$ H-NMR $\left(\mathrm{CDCl}_{3}, 300 \mathrm{MHz}\right): \delta=7.66(\mathrm{~s}, 1 \mathrm{H}), 7.62(\mathrm{~d}, J=7.8 \mathrm{~Hz}, 1 \mathrm{H}), 7.53(\mathrm{~s}, 1 \mathrm{H}), 7.47$ (d, $J=7.8 \mathrm{~Hz}, 1 \mathrm{H}), 7.43-7.38(\mathrm{~m}, 2 \mathrm{H}), 7.37-7.31(\mathrm{~m}, 2 \mathrm{H}), 7.29-7.23(\mathrm{~m}, 1 \mathrm{H}), 6.97(\mathrm{~d}$, $J=8.9 \mathrm{~Hz}, 2 \mathrm{H}), 3.87$ (s, 3H), 2.46 (s, 3H), 2.43 (s, 3H).

${ }^{13}$ C-NMR $\left(\mathrm{CDCl}_{3}, 126 \mathrm{MHz}\right): \delta=158.8\left(\mathrm{C}_{\mathrm{q}}\right), 152.9\left(\mathrm{C}_{\mathrm{q}}\right), 149.4\left(\mathrm{C}_{\mathrm{q}}\right), 138.8\left(\mathrm{C}_{\mathrm{q}}\right), 137.7\left(\mathrm{C}_{\mathrm{q}}\right)$, $137.3\left(\mathrm{C}_{\mathrm{q}}\right), 131.9(\mathrm{CH}), 131.5(\mathrm{CH}), 131.4(\mathrm{CH}), 131.1\left(\mathrm{C}_{\mathrm{q}}\right), 130.4(\mathrm{CH}), 128.7(\mathrm{CH}), 124.0$ $(\mathrm{CH}), 120.0(\mathrm{CH}), 116.0(\mathrm{CH}), 113.0(\mathrm{CH}), 55.3\left(\mathrm{CH}_{3}\right), 21.4\left(\mathrm{CH}_{3}\right), 21.2\left(\mathrm{CH}_{3}\right)$.

IR (ATR): 2962, 2914, 2856, 1606, 1518, 1249, 1177, 1016, 816, 791, 689, $538 \mathrm{~cm}^{-1}$.

MS (EI) $m / z$ (relative intensity): $316\left(\left[\mathrm{M}^{+}\right]\right.$100), 301 (40), 197 (67), 182 (65), 153 (42), 91 (78), 65 (30).

HR-MS (EI) $m / z$ for $\mathrm{C}_{21} \mathrm{H}_{20} \mathrm{~N}_{2} \mathrm{O}\left[\mathbf{M}^{+}\right]$

calcd.: 316.1576 .

found: 316.1577 . 
Synthesis of $(E)-4$ '-Methyl-2' -(m-tolyldiazenyl)-[1,1'-biphenyl]-4-carbaldehyde (83ag)

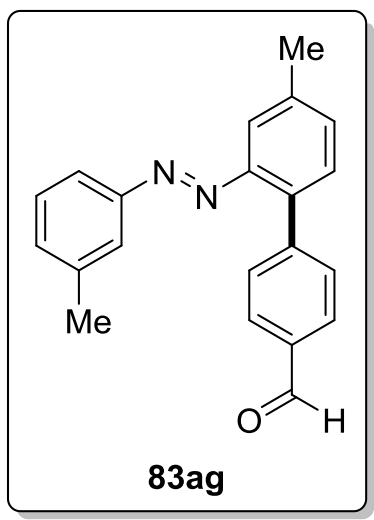

The general procedure D was followed using 13a $(210 \mathrm{mg}, 1.00 \mathrm{mmol})$ and 4-bromobenzaldehyde (52g) (93 $\mathrm{mg}, 0.50 \mathrm{mmol}$ ). Purification by column chromatography ( $n$-hexane/ $\mathrm{CH}_{2} \mathrm{Cl}_{2}: 7 / 3$ ) yielded 83ag (80 mg, 51\%) as an orange solid.

M. p.: $101-102{ }^{\circ} \mathrm{C}$.

${ }^{1} \mathbf{H}-\mathbf{N M R}\left(\mathrm{CDCl}_{3}, 500 \mathrm{MHz}\right): \delta=10.07(\mathrm{~s}, 1 \mathrm{H}), 7.91(\mathrm{~d}, J=8.4 \mathrm{~Hz}, 2 \mathrm{H}), 7.62(\mathrm{~d}, J=8.1 \mathrm{~Hz}$, 2H), 7.59 (s, 1H), 7.57 (s, 1H), $7.54(\mathrm{~d}, J=7.3 \mathrm{~Hz}, 1 \mathrm{H}), 7.47$ (d, $J=7.8 \mathrm{~Hz}, 1 \mathrm{H}), 7.38$ (ddd, $J=7.8,1.8,0.8 \mathrm{~Hz}, 1 \mathrm{H}), 7.33(\mathrm{t}, J=7.7 \mathrm{~Hz}, 1 \mathrm{H}), 7.25(\mathrm{~d}, J=9.7 \mathrm{~Hz}, 1 \mathrm{H}), 2.47(\mathrm{~s}, 3 \mathrm{H}), 2.40$ $(\mathrm{s}, 3 \mathrm{H})$.

${ }^{13}$ C-NMR $\left(\mathrm{CDCl}_{3}, 126 \mathrm{MHz}\right): \delta=192.2\left(\mathrm{C}_{\mathrm{q}}\right), 152.8\left(\mathrm{C}_{\mathrm{q}}\right), 149.5\left(\mathrm{C}_{\mathrm{q}}\right), 145.4\left(\mathrm{C}_{\mathrm{q}}\right), 139.3\left(\mathrm{C}_{\mathrm{q}}\right)$, $139.0\left(\mathrm{C}_{\mathrm{q}}\right), 137.0\left(\mathrm{C}_{\mathrm{q}}\right), 134.9\left(\mathrm{C}_{\mathrm{q}}\right), 131.9(\mathrm{CH}), 131.7(\mathrm{CH}), 131.5(\mathrm{CH}), 130.5(\mathrm{CH}), 128.9$ $(\mathrm{CH}), 128.9(\mathrm{CH}), 124.3(\mathrm{CH}), 119.9(\mathrm{CH}), 116.3(\mathrm{CH}), 21.4\left(\mathrm{CH}_{3}\right), 21.3\left(\mathrm{CH}_{3}\right)$.

IR (ATR): 2915, 2816, 2727, 1694, 1603, 1210, 818, 792, 686, $537 \mathrm{~cm}^{-1}$.

MS (EI) $m / z$ (relative intensity): 314 ([M+] 79), 195 (32), 165 (60), 152 (47), 91 (100), 65 (31), 43 (33).

HR-MS (EI) $m / z$ for $\mathrm{C}_{21} \mathrm{H}_{18} \mathrm{~N}_{2} \mathrm{O}\left[\mathbf{M}^{+}\right]$

calcd.: 314.1419 .

found: 314.1430 . 
Synthesis of $(E)-1-\left\{4^{\prime}\right.$-Methyl-2'-(m-tolyldiazenyl)-[1,1'-biphenyl]-4-yl\}ethan-1-one (83ac)

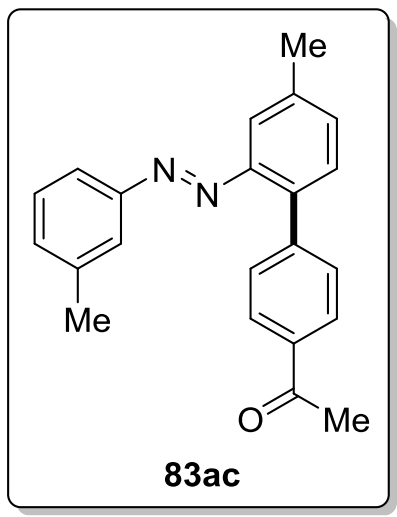

The general procedure D was followed using 13a $(210 \mathrm{mg}, 1.00 \mathrm{mmol})$ and 1-(4-bromophenyl)ethan-1-one $\quad \mathbf{( 5 2 c )} \quad(100 \mathrm{mg}, \quad 0.50 \mathrm{mmol})$. Purification by column chromatography ( $n$-hexane/ $\mathrm{CH}_{2} \mathrm{Cl}_{2}: 7 / 3$ ) yielded 83ac (106 mg, 65\%) as an orange solid.

M. p.: $123-124^{\circ} \mathrm{C}$.

${ }^{1} \mathbf{H}-\mathbf{N M R}\left(\mathrm{CDCl}_{3}, 300 \mathrm{MHz}\right): \delta=8.00(\mathrm{~d}, J=8.6 \mathrm{~Hz}, 2 \mathrm{H}), 7.61(\mathrm{~s}, 1 \mathrm{H}), 7.59-7.51(\mathrm{~m}, 4 \mathrm{H})$, $7.46(\mathrm{~d}, J=7.8 \mathrm{~Hz}, 1 \mathrm{H}), 7.39-7.29(\mathrm{~m}, 2 \mathrm{H}), 7.28-7.21(\mathrm{~m}, 1 \mathrm{H}), 2.64$ (s, 3H), 2.47 (s, 3H), $2.40(\mathrm{~s}, 3 \mathrm{H})$.

${ }^{13}$ C-NMR $\left(\mathrm{CDCl}_{3}, 126 \mathrm{MHz}\right): \delta=198.1\left(\mathrm{C}_{\mathrm{q}}\right), 152.9\left(\mathrm{C}_{\mathrm{q}}\right), 149.6\left(\mathrm{C}_{\mathrm{q}}\right), 144.0\left(\mathrm{C}_{\mathrm{q}}\right), 139.0\left(\mathrm{C}_{\mathrm{q}}\right)$, $138.9\left(\mathrm{C}_{\mathrm{q}}\right), 137.2\left(\mathrm{C}_{\mathrm{q}}\right), 135.6\left(\mathrm{C}_{\mathrm{q}}\right), 131.9(\mathrm{CH}), 131.7(\mathrm{CH}), 131.0(\mathrm{CH}), 130.5(\mathrm{CH}), 129.0$ $(\mathrm{CH}), 127.6(\mathrm{CH}), 124.4(\mathrm{CH}), 119.9(\mathrm{CH}), 116.3(\mathrm{CH}), 26.5\left(\mathrm{CH}_{3}\right), 21.2\left(\mathrm{CH}_{3}\right), 21.1\left(\mathrm{CH}_{3}\right)$.

IR (ATR): 2914, 2856, 2723, 1679, 1600, 1266, 819, 797, 688, $599 \mathrm{~cm}^{-1}$.

MS (EI) $m / z$ (relative intensity): 328 ([M+] 100), 285 (44), 209 (25), 165 (41), 91 (83), 65 (19), 65 (20), 43 (76).

HR-MS (EI) $m / z$ for $\mathrm{C}_{22} \mathrm{H}_{20} \mathrm{~N}_{2} \mathrm{O}\left[\mathrm{M}^{+}\right]$

calcd.: 328.1576 .

found: 328.1572 . 
Synthesis of Ethyl (E)-4'-methyl-2'-(m-tolyldiazenyl)-[1,1'-biphenyl]-4-carboxylate (83ah)

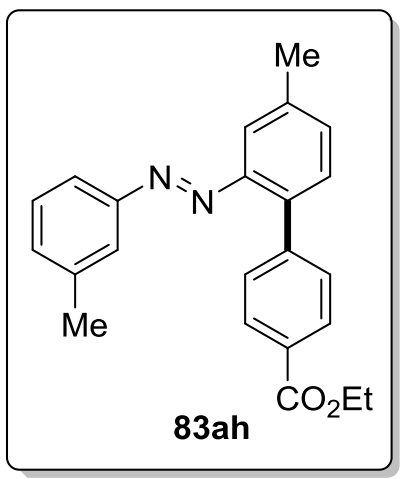

The general procedure D was followed using 13a $(210 \mathrm{mg}, 1.00 \mathrm{mmol})$ and ethyl 4-bromobenzoate $(\mathbf{5 2 h})(115 \mathrm{mg}, 0.50 \mathrm{mmol})$. Purification by column chromatography ( $n$-hexane/ $\mathrm{CH}_{2} \mathrm{Cl}_{2}: 7 / 3$ ) yielded 83ah (113 $\mathrm{mg}, 63 \%$ ) as an orange solid.

M. p.: $94-95^{\circ} \mathrm{C}$.

${ }^{1} \mathbf{H}-\mathbf{N M R}\left(\mathrm{CDCl}_{3}, 300 \mathrm{MHz}\right): \delta=8.09(\mathrm{~d}, J=8.5 \mathrm{~Hz}, 2 \mathrm{H}), 7.63-7.60(\mathrm{~m}, 1 \mathrm{H}), 7.58-7.50(\mathrm{~m}$, $4 \mathrm{H}), 7.47(\mathrm{~d}, J=7.9 \mathrm{~Hz}, 1 \mathrm{H}), 7.39-7.30(\mathrm{~m}, 2 \mathrm{H}), 7.28-7.22(\mathrm{~m}, 1 \mathrm{H}), 4.41(\mathrm{q}, J=7.1 \mathrm{~Hz}, 2 \mathrm{H})$, $2.47(\mathrm{~s}, 3 \mathrm{H}), 2.41(\mathrm{~s}, 3 \mathrm{H}), 1.41(\mathrm{t}, J=7.1 \mathrm{~Hz}, 3 \mathrm{H})$.

${ }^{13} \mathrm{C}-\mathrm{NMR}\left(\mathrm{CDCl}_{3}, 126 \mathrm{MHz}\right): \delta=166.8\left(\mathrm{C}_{\mathrm{q}}\right), 153.0\left(\mathrm{C}_{\mathrm{q}}\right), 149.6\left(\mathrm{C}_{\mathrm{q}}\right), 143.7\left(\mathrm{C}_{\mathrm{q}}\right), 139.0\left(\mathrm{C}_{\mathrm{q}}\right)$, $138.9\left(\mathrm{C}_{\mathrm{q}}\right), 137.4\left(\mathrm{C}_{\mathrm{q}}\right), 131.9(\mathrm{CH}), 131.7(\mathrm{CH}), 130.8(\mathrm{CH}), 130.6(\mathrm{CH}), 129.0\left(\mathrm{C}_{\mathrm{q}}\right), 128.9$ $(\mathrm{CH}), 128.8(\mathrm{CH}), 124.4(\mathrm{CH}), 119.9(\mathrm{CH}), 116.3(\mathrm{CH}), 60.9\left(\mathrm{CH}_{2}\right), 21.3\left(\mathrm{CH}_{3}\right), 21.1\left(\mathrm{CH}_{3}\right)$, $14.3\left(\mathrm{CH}_{3}\right)$.

IR (ATR): 2979, 2921, 2867, 1713, 1607, 1268, 1180, 1100, 775, $688 \mathrm{~cm}^{-1}$.

MS (EI) $m / z$ (relative intensity): 358 ([M+] 47), 329 (100), 285 (37), 239 (19), 211 (17), 165 (60), 91 (80), 65 (14).

HR-MS (EI) $m / z$ for $\mathrm{C}_{23} \mathrm{H}_{22} \mathrm{~N}_{2} \mathrm{O}_{2}\left[\mathbf{M}^{+}\right]$ calcd.: 358.1681. found: 358.1669 . 
Synthesis of $(E)-4$ '-Methyl-2' -(m-tolyldiazenyl)-[1,1'-biphenyl]-4-carbonitrile (83ai)

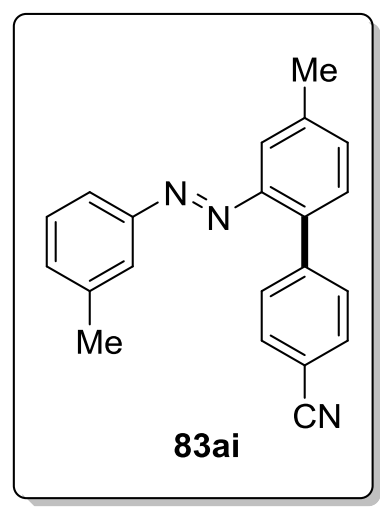

The general procedure D was followed using 13a $(210 \mathrm{mg}, 1.00 \mathrm{mmol})$ and 4-bromobenzonitrile (52i) $(91 \mathrm{mg}, 0.50 \mathrm{mmol})$. Purification by column chromatography (n-hexane/ $\mathrm{CH}_{2} \mathrm{Cl}_{2}: 7 / 3$ ) yielded 83ai (100 $\mathrm{mg}, 64 \%$ ) as an orange solid.

M. p.: $121-122^{\circ} \mathrm{C}$.

${ }^{1} \mathbf{H}-\mathbf{N M R}\left(\mathrm{CDCl}_{3}, 500 \mathrm{MHz}\right): \delta=7.58(\mathrm{~d}, J=8.6 \mathrm{~Hz}, 2 \mathrm{H}), 7.59-7.56(\mathrm{~m}, 2 \mathrm{H}), 7.55(\mathrm{~d}$, $J=8.6 \mathrm{~Hz}, 2 \mathrm{H}), 7.53-7.51(\mathrm{~m}, 1 \mathrm{H}), 7.43(\mathrm{~d}, J=7.9 \mathrm{~Hz}, 1 \mathrm{H}), 7.39-7.33(\mathrm{~m}, 2 \mathrm{H}), 7.27(\mathrm{~d}$, $J=8.0 \mathrm{~Hz}, 1 \mathrm{H}), 2.47(\mathrm{~s}, 3 \mathrm{H}), 2.41(\mathrm{~s}, 3 \mathrm{H})$.

${ }^{13}$ C-NMR $\left(\mathrm{CDCl}_{3}, 126 \mathrm{MHz}\right): \delta=152.8\left(\mathrm{C}_{\mathrm{q}}\right), 149.3\left(\mathrm{C}_{\mathrm{q}}\right), 143.8\left(\mathrm{C}_{\mathrm{q}}\right), 139.5\left(\mathrm{C}_{\mathrm{q}}\right), 139.1\left(\mathrm{C}_{\mathrm{q}}\right)$, $136.5\left(\mathrm{C}_{\mathrm{q}}\right), 132.0(\mathrm{CH}), 131.8(\mathrm{CH}), 131.4(\mathrm{CH}), 131.2(\mathrm{CH}), 130.3(\mathrm{CH}), 129.0(\mathrm{CH}), 124.1$ $(\mathrm{CH}), 120.0(\mathrm{CH}), 119.1\left(\mathrm{C}_{\mathrm{q}}\right), 116.3(\mathrm{CH}), 110.7\left(\mathrm{C}_{\mathrm{q}}\right), 21.3\left(\mathrm{CH}_{3}\right), 21.3\left(\mathrm{CH}_{3}\right)$.

IR (ATR): 2968, 2919, 2857, 2225, 1603, 1484, 812, 787, 682, 589, $544 \mathrm{~cm}^{-1}$.

MS (EI) $m / z$ (relative intensity): $311\left(\left[\mathrm{M}^{+}\right]\right.$58), 192 (56), 165 (32), 119 (18), 91 (100), 65 (27).

HR-MS (EI) $m / z$ for $\mathrm{C}_{21} \mathrm{H}_{17} \mathrm{~N}_{3}\left[\mathbf{M}^{+}\right]$

calcd.: 311.1422 .

found: 311.1419 . 
Synthesis of (E)-1-(4-Methyl-4'-nitro-[1,1'-biphenyl]-2-yl)-2-(m-tolyl)diazene (83aj)

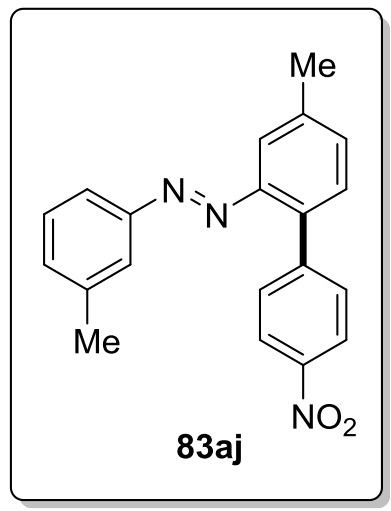

The general procedure D was followed using 13a $(210 \mathrm{mg}, 1.00 \mathrm{mmol})$ and 1-bromo-4nitrobenzene $(\mathbf{5 2 j}) \quad(101 \mathrm{mg}, \quad 0.50 \mathrm{mmol})$. Purification by column chromatography (n-hexane/ $\mathrm{CH}_{2} \mathrm{Cl}_{2}: 7 / 3$ ) yielded 83aj ( $89 \mathrm{mg}, 54 \%$ ) as an orange solid.

M. p.: $134-135^{\circ} \mathrm{C}$.

${ }^{1} \mathbf{H}-\mathbf{N M R}\left(\mathrm{CDCl}_{3}, 500 \mathrm{MHz}\right): \delta=8.25(\mathrm{~d}, J=8.9 \mathrm{~Hz}, 2 \mathrm{H}), 7.63-7.57(\mathrm{~m}, 4 \mathrm{H}), 7.53(\mathrm{~d}$, $J=7.9 \mathrm{~Hz}, 1 \mathrm{H}), 7.45(\mathrm{~d}, J=7.8 \mathrm{~Hz}, 1 \mathrm{H}), 7.38(\mathrm{ddd}, J=7.9,1.8,0.6 \mathrm{~Hz}, 1 \mathrm{H}), 7.35(\mathrm{t}$, $J=7.7 \mathrm{~Hz}, 1 \mathrm{H}), 7.27(\mathrm{~d}, J=7.5 \mathrm{~Hz}, 1 \mathrm{H}), 2.48(\mathrm{~s}, 3 \mathrm{H}), 2.41(\mathrm{~s}, 3 \mathrm{H})$.

${ }^{13} \mathbf{C}-\mathbf{N M R}\left(\mathrm{CDCl}_{3}, 126 \mathrm{MHz}\right): \delta=152.8\left(\mathrm{C}_{\mathrm{q}}\right), 149.3\left(\mathrm{C}_{\mathrm{q}}\right), 146.9\left(\mathrm{C}_{\mathrm{q}}\right), 145.9\left(\mathrm{C}_{\mathrm{q}}\right), 139.8\left(\mathrm{C}_{\mathrm{q}}\right)$, $139.1\left(\mathrm{C}_{\mathrm{q}}\right), 136.1\left(\mathrm{C}_{\mathrm{q}}\right), 132.1(\mathrm{CH}), 131.8(\mathrm{CH}), 131.5(\mathrm{CH}), 130.4(\mathrm{CH}), 129.0(\mathrm{CH}), 124.3$ $(\mathrm{CH}), 122.7(\mathrm{CH}), 119.9(\mathrm{CH}), 116.4(\mathrm{CH}), 21.4\left(\mathrm{CH}_{3}\right), 21.3\left(\mathrm{CH}_{3}\right)$.

IR (ATR): 2915, 2856, 1596, 1506, 1345, 853, 810, 786, 733, 695, $685 \mathrm{~cm}^{-1}$.

MS (EI) $m / z$ (relative intensity): 331 ([M+] 39), 212 (32), 165 (56), 119 (22), 91 (100), 65 (24).

HR-MS (EI) $m / z$ for $\mathrm{C}_{20} \mathrm{H}_{17} \mathrm{~N}_{3} \mathrm{O}_{2}\left[\mathrm{M}^{+}\right]$ calcd.: 331.1321 . found: 331.1319 . 
Synthesis of (E)-1-(3'-Methoxy-4-methyl-[1,1'-biphenyl]-2-yl)-2-(m-tolyl)diazene (83ak)

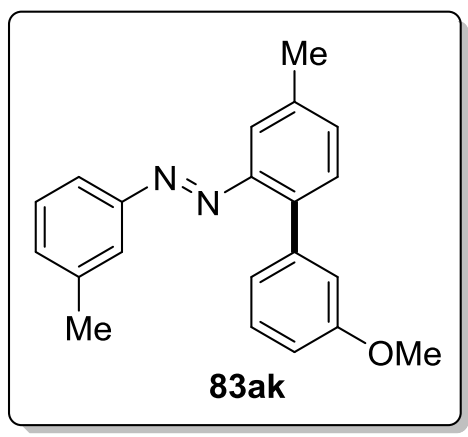

The general procedure D was followed using 13a $(210 \mathrm{mg}, 1.00 \mathrm{mmol})$ and 1-bromo-3methoxybenzene (52k) (94 mg, $0.50 \mathrm{mmol})$. Purification by column chromatography (n-hexane/ $\mathrm{CH}_{2} \mathrm{Cl}_{2}: 7 / 3$ ) yielded 83ak $(89 \mathrm{mg}, 56 \%)$ a viscous orange liquid.

${ }^{1} \mathbf{H}-\mathbf{N M R}\left(\mathrm{CDCl}_{3}, 500 \mathrm{MHz}\right): \delta=7.65(\mathrm{~m}, 2 \mathrm{H}), 7.57-7.54(\mathrm{~m}, 1 \mathrm{H}), 7.51$ (ddd, $J=7.8,4.0$, $1.4 \mathrm{~Hz}, 1 \mathrm{H}), 7.40-7.31(\mathrm{~m}, 3 \mathrm{H}), 7.26$ (d, J=7.4 Hz, 1H), 7.09-7.03 (m, 2H), 6.97-6.92 (m, $1 \mathrm{H}), 3.81(\mathrm{~s}, 3 \mathrm{H}), 2.48(\mathrm{~s}, 3 \mathrm{H}), 2.42(\mathrm{~s}, 3 \mathrm{H})$.

${ }^{13} \mathrm{C}-\mathrm{NMR}\left(\mathrm{CDCl}_{3}, 126 \mathrm{MHz}\right): \delta=158.9\left(\mathrm{C}_{\mathrm{q}}\right), 153.0\left(\mathrm{C}_{\mathrm{q}}\right), 149.6\left(\mathrm{C}_{\mathrm{q}}\right), 140.2\left(\mathrm{C}_{\mathrm{q}}\right), 138.9\left(\mathrm{C}_{\mathrm{q}}\right)$, $138.1\left(\mathrm{C}_{\mathrm{q}}\right), 138.0\left(\mathrm{C}_{\mathrm{q}}\right), 131.6(\mathrm{CH}), 131.5(\mathrm{CH}), 130.6(\mathrm{CH}), 128.8(\mathrm{CH}), 128.4(\mathrm{CH}), 123.8$ $(\mathrm{CH}), 123.5(\mathrm{CH}), 120.3(\mathrm{CH}), 116.3(\mathrm{CH}), 116.1(\mathrm{CH}), 113.0(\mathrm{CH}), 55.2\left(\mathrm{CH}_{3}\right), 21.3\left(\mathrm{CH}_{3}\right)$, $21.2\left(\mathrm{CH}_{3}\right)$.

IR (ATR): 3024, 2918, 2832, 1599, 1477, 1283, 1208, 1023, 821, 786, 746, $688 \mathrm{~cm}^{-1}$.

MS (EI) m/z (relative intensity): 316 ([M $\left.\mathrm{M}^{+}\right]$100), 285 (52), 197 (55), 182 (69), 153 (40), 91 (86), 65 (34).

HR-MS (EI) $m / z$ for $\mathrm{C}_{21} \mathrm{H}_{20} \mathrm{~N}_{2} \mathrm{O}\left[\mathbf{M}^{+}\right]$

calcd.: 316.1576 .

found: 316.1571 . 
Synthesis of $(E)-1-(m$-Tolyl)-2-(3',4',5'-trimethoxy-4-methyl-[1,1'-biphenyl]-2-yl)diazene (83al)

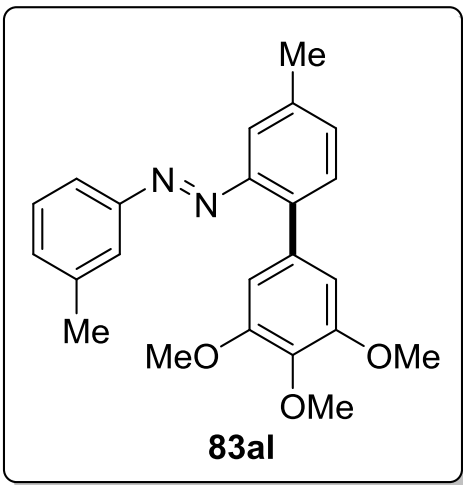

The general procedure D was followed using 13a $(210 \mathrm{mg}, 1.00 \mathrm{mmol})$ and 5-bromo-1,2,3trimethoxybenzene (52l) $(124 \mathrm{mg}, 0.50 \mathrm{mmol})$. Purification by column chromatography (n-hexane/ $\mathrm{CH}_{2} \mathrm{Cl}_{2}: 7 / 3$ ) yielded 83al (161 $\mathrm{mg}, 86 \%$ ) as an orange solid.

M. p.: $138-139{ }^{\circ} \mathrm{C}$.

${ }^{1}$ H-NMR $\left(\mathrm{CDCl}_{3}, 500 \mathrm{MHz}\right): \delta=7.64(\mathrm{~m}, 2 \mathrm{H}), 7.54-7.48(\mathrm{~m}, 2 \mathrm{H}), 7.38-7.32(\mathrm{~m}, 2 \mathrm{H}), 7.25$ $(\mathrm{d}, J=7.7 \mathrm{~Hz}, 1 \mathrm{H}), 6.68(\mathrm{~s}, 2 \mathrm{H}) 3.91(\mathrm{~s}, 3 \mathrm{H}), 3.81(\mathrm{~s}, 6 \mathrm{H}), 2.45$ (s, 3H), 2.39 (s, 3H).

${ }^{13}$ C-NMR $\left(\mathrm{CDCl}_{3}, 126 \mathrm{MHz}\right): \delta=152.9\left(\mathrm{C}_{\mathrm{q}}\right), 152.4\left(\mathrm{C}_{\mathrm{q}}\right), 149.7\left(\mathrm{C}_{\mathrm{q}}\right), 138.9\left(\mathrm{C}_{\mathrm{q}}\right), 138.1\left(\mathrm{C}_{\mathrm{q}}\right)$, $137.8\left(\mathrm{C}_{\mathrm{q}}\right), 137.3\left(\mathrm{C}_{\mathrm{q}}\right), 134.3\left(\mathrm{C}_{\mathrm{q}}\right), 131.7(\mathrm{CH}), 131.5(\mathrm{CH}), 130.3(\mathrm{CH}), 128.9(\mathrm{CH}), 123.5$ $(\mathrm{CH}), 120.5(\mathrm{CH}), 116.3(\mathrm{CH}), 108.3(\mathrm{CH}), 60.9\left(\mathrm{CH}_{3}\right), 56.0\left(\mathrm{CH}_{3}\right), 21.3\left(\mathrm{CH}_{3}\right), 21.1\left(\mathrm{CH}_{3}\right)$.

IR (ATR): 2948, 2921, 2825, 1584, 1449, 1412, 1235, 1120, 1011, 817, 790, $686 \mathrm{~cm}^{-1}$.

MS (EI) $\mathrm{m} / z$ (relative intensity): 376 ([M+] 45), 345 (100), 226 (33), 211 (30), 91 (37).

HR-MS (EI) $m / z$ for $\mathrm{C}_{23} \mathrm{H}_{24} \mathrm{~N}_{2} \mathrm{O}_{3}\left[\mathrm{M}^{+}\right]$ calcd.: 376.1787 . found: 376.1787 . 
Synthesis of $(E)-1-\left(3^{\prime}, 4^{\prime}\right.$-Dichloro-4-methyl-[1,1'-biphenyl]-2-yl)-2-(m-tolyl)diazene (83am)

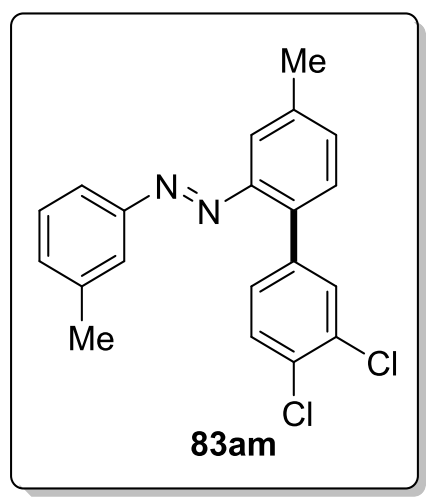

The general procedure D was followed using 13a $(210 \mathrm{mg}, 1.00 \mathrm{mmol})$ and 4-bromo-1,2dichlorobenzene $\mathbf{( 5 2 m )}(113 \mathrm{mg}, 0.50 \mathrm{mmol})$. Purification by column chromatography ( $n$-hexane/ $\mathrm{CH}_{2} \mathrm{Cl}_{2}$ : 7/3) yielded 83am (112 mg, 63\%) as an orange solid.

M. p.: $127-128^{\circ} \mathrm{C}$.

${ }^{1} \mathbf{H}-\mathbf{N M R}\left(\mathrm{CDCl}_{3}, 500 \mathrm{MHz}\right): \delta=7.62-7.56(\mathrm{~m}, 4 \mathrm{H}), 7.46(\mathrm{~d}, J=8.3 \mathrm{~Hz}, 1 \mathrm{H}), 7.42(\mathrm{~d}$, $J=7.8 \mathrm{~Hz}, 1 \mathrm{H}), 7.38-7.33(\mathrm{~m}, 2 \mathrm{H}), 7.29-7.25(\mathrm{~m}, 2 \mathrm{H}), 2.46(\mathrm{~s}, 3 \mathrm{H}), 2.42(\mathrm{~s}, 3 \mathrm{H})$.

${ }^{13} \mathrm{C}-\mathrm{NMR}\left(\mathrm{CDCl}_{3}, 126 \mathrm{MHz}\right): \delta=152.9\left(\mathrm{C}_{\mathrm{q}}\right), 149.1\left(\mathrm{C}_{\mathrm{q}}\right), 139.1\left(\mathrm{C}_{\mathrm{q}}\right), 139.0\left(\mathrm{C}_{\mathrm{q}}\right), 138.8\left(\mathrm{C}_{\mathrm{q}}\right)$, $136.0\left(\mathrm{C}_{\mathrm{q}}\right), 132.6(\mathrm{CH}), 131.9(\mathrm{CH}), 131.8(\mathrm{CH}), 131.7\left(\mathrm{C}_{\mathrm{q}}\right), 131.3\left(\mathrm{C}_{\mathrm{q}}\right), 130.2(\mathrm{CH}), 130.1$ $(\mathrm{CH}), 129.4(\mathrm{CH}), 129.0(\mathrm{CH}), 123.7(\mathrm{CH}), 120.5(\mathrm{CH}), 116.2(\mathrm{CH}), 21.4\left(\mathrm{CH}_{3}\right), 21.2\left(\mathrm{CH}_{3}\right)$.

IR (ATR): 3026, 2918, 2858, 1601, 1463, 1371, 1133, 1027, 882, 826, 808, $686 \mathrm{~cm}^{-1}$.

MS (EI) $m / z$ (relative intensity): 354 ([M+] 55), 235 (43), 200 (62), 165 (61), 91 (100), 65 (36).

HR-MS (EI) $m / z$ for $\mathrm{C}_{20} \mathrm{H}_{16} \mathrm{Cl}_{2} \mathrm{~N}_{2}\left[\mathrm{M}^{+}\right] \quad$ calcd.: 354.0691 . found: 354.0686 . 
Synthesis of $(E)-1-\{5-M e t h y l-2-(t h i o p h e n-2-y l) p h e n y l\}-2-(m-t o l y l) d i a z e n e ~(83 a n)$

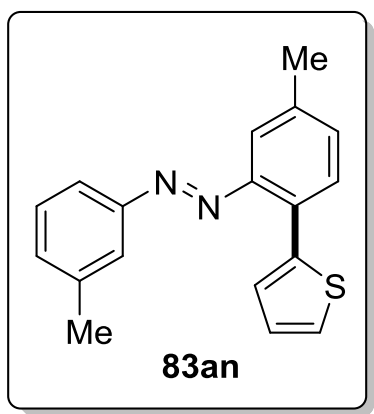

The general procedure D was followed using 13a $(210 \mathrm{mg}, 1.00 \mathrm{mmol})$ and 2-bromothiophene $\mathbf{( 5 2 n )}(82 \mathrm{mg}, 0.50 \mathrm{mmol})$. Purification by column chromatography (n-hexane/ $\mathrm{CH}_{2} \mathrm{Cl}_{2}: 7 / 3$ ) yielded 83an (91 $\mathrm{mg}, 62 \%$ ) as a viscous orange liquid.

${ }^{\mathbf{1}} \mathbf{H}-\mathbf{N M R}\left(\mathrm{CDCl}_{3}, 400 \mathrm{MHz}\right): \delta=7.83(\mathrm{~d}, J=8.7 \mathrm{~Hz}, 1 \mathrm{H}), 7.74(\mathrm{~m}, 2 \mathrm{H}), 7.55-7.29(\mathrm{~m}, 6 \mathrm{H})$, $7.14(\mathrm{dd}, J=5.2,3.8 \mathrm{~Hz}, 1 \mathrm{H}), 2.48(\mathrm{~s}, 3 \mathrm{H}), 2.45(\mathrm{~s}, 3 \mathrm{H})$.

${ }^{13} \mathrm{C}-\mathrm{NMR}\left(\mathrm{CDCl}_{3}, 126 \mathrm{MHz}\right): \delta=152.8\left(\mathrm{C}_{\mathrm{q}}\right), 148.3\left(\mathrm{C}_{\mathrm{q}}\right), 139.8\left(\mathrm{C}_{\mathrm{q}}\right), 138.9\left(\mathrm{C}_{\mathrm{q}}\right), 137.9\left(\mathrm{C}_{\mathrm{q}}\right)$, $131.8(\mathrm{CH}), 131.6(\mathrm{CH}), 130.9\left(\mathrm{C}_{\mathrm{q}}\right), 128.8(\mathrm{CH}), 128.3(\mathrm{CH}), 126.8(\mathrm{CH}), 124.7(\mathrm{CH}), 122.8$ $(\mathrm{CH}), 120.6(\mathrm{CH}), 120.4(\mathrm{CH}), 116.2(\mathrm{CH}), 21.3\left(\mathrm{CH}_{3}\right), 21.1\left(\mathrm{CH}_{3}\right)$.

IR (ATR): 3050, 2917, 2858, 1599, 1482, 1240, 1083, 814, 790, 695, 515, $446 \mathrm{~cm}^{-1}$.

MS (EI) m/z (relative intensity): 292 ([M+] 40), 259 (33), 173 (47), 129 (35), 91 (100), 65 (31).

HR-MS (EI) $m / z$ for $\mathrm{C}_{18} \mathrm{H}_{16} \mathrm{~N}_{2} \mathrm{~S}\left[\mathrm{M}^{+}\right]$

calcd.: 292.1034.

found: 292.1023 . 


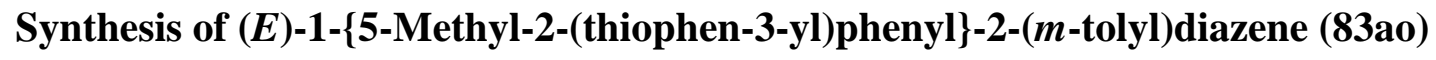

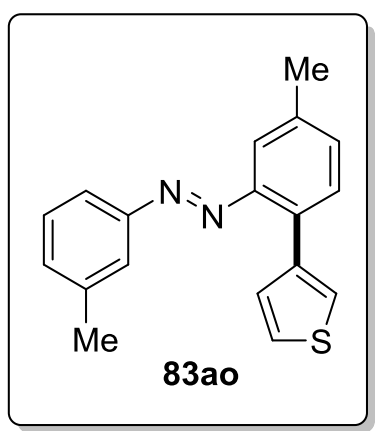

The general procedure D was followed using 13a $(210 \mathrm{mg}, 1.00 \mathrm{mmol})$ and 3-bromothiophene (52o) (82 $\mathrm{mg}, 0.50 \mathrm{mmol})$. Purification by column chromatography ( $n$-hexane/ $\mathrm{CH}_{2} \mathrm{Cl}_{2}: 7 / 3$ ) yielded $\mathbf{8 3 a o}(75 \mathrm{mg}, 51 \%$ ) as a viscous orange liquid.

${ }^{1} \mathbf{H}-\mathbf{N M R}\left(\mathrm{CDCl}_{3}, 400 \mathrm{MHz}\right): \delta=7.67(\mathrm{~m}, 2 \mathrm{H}), 7.55(\mathrm{~d}, J=7.9 \mathrm{~Hz}, 1 \mathrm{H}), 7.51-7.46(\mathrm{~m}, 1 \mathrm{H})$, $7.39(\mathrm{~d}, J=7.7 \mathrm{~Hz}, 1 \mathrm{H}), 7.36-7.33(\mathrm{~m}, 3 \mathrm{H}), 7.31$ (ddd, $J=7.9,1.9,0.7 \mathrm{~Hz}, 1 \mathrm{H}), 7.27(\mathrm{~d}$, $J=7.5 \mathrm{~Hz}, 1 \mathrm{H}), 2.45(\mathrm{~s}, 3 \mathrm{H}), 2.43(\mathrm{~s}, 3 \mathrm{H})$.

${ }^{13} \mathbf{C}-\mathrm{NMR}\left(\mathrm{CDCl}_{3}, 126 \mathrm{MHz}\right): \delta=153.0\left(\mathrm{C}_{\mathrm{q}}\right), 149.6\left(\mathrm{C}_{\mathrm{q}}\right), 139.0\left(\mathrm{C}_{\mathrm{q}}\right), 139.0\left(\mathrm{C}_{\mathrm{q}}\right), 137.8\left(\mathrm{C}_{\mathrm{q}}\right)$, $132.6\left(\mathrm{C}_{\mathrm{q}}\right), 131.7(\mathrm{CH}), 131.7(\mathrm{CH}), 129.9(\mathrm{CH}), 129.9(\mathrm{CH}), 128.9(\mathrm{CH}), 124.8(\mathrm{CH}), 124.3$ $(\mathrm{CH}), 124.1(\mathrm{CH}), 120.3(\mathrm{CH}), 116.3(\mathrm{CH}), 21.4\left(\mathrm{CH}_{3}\right), 21.2\left(\mathrm{CH}_{3}\right)$.

IR (ATR): 3089, 3025, 2913, 2855, 1607, 1494, 1190, 1082, 861, 824, 783, $741 \mathrm{~cm}^{-1}$.

MS (EI) $m / z$ (relative intensity): 292 ([M+ $]$ 100), 173 (68), 129 (40), 91 (79), 65 (23).

HR-MS (EI) $m / z$ for $\mathrm{C}_{18} \mathrm{H}_{16} \mathrm{~N}_{2} \mathrm{~S}\left[\mathbf{M}^{+}\right]$ calcd.: 292.1034 . found: 292.1024 . 


\section{Synthesis of $(E)-5-\{4-M e t h y l-2-(m$-tolyldiazenyl)phenyl\}-1H-indole (83ap)}

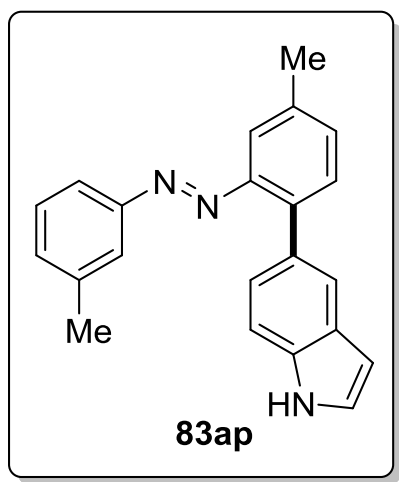

The general procedure D was followed using 13a $(210 \mathrm{mg}, 1.00 \mathrm{mmol})$ and 5-bromo- $1 \mathrm{H}$ indole (52p) $\quad(98 \mathrm{mg}, \quad 0.50 \mathrm{mmol})$. Purification by column chromatography ( $n$-hexane $/ \mathrm{CH}_{2} \mathrm{Cl}_{2}: 7 / 3$ ) yielded 83ap ( $88 \mathrm{mg}, 54 \%$ ) as a yellow solid.

M. p.: $72-73{ }^{\circ} \mathrm{C}$.

${ }^{1} \mathbf{H}-\mathbf{N M R}\left(\mathrm{CDCl}_{3}, 500 \mathrm{MHz}\right): \delta=8.17(\mathrm{bs}, 1 \mathrm{H}), 7.77-7.70(\mathrm{~m}, 1 \mathrm{H}), 7.64-7.51(\mathrm{~m}, 3 \mathrm{H}), 7.40$ (ddd, $J=8.4,0.8,0.8 \mathrm{~Hz}, 1 \mathrm{H}), 7.35(\mathrm{ddd}, J=7.8,1.8,0.6 \mathrm{~Hz}, 1 \mathrm{H}), 7.32-7.28(\mathrm{~m}, 2 \mathrm{H}), 7.26-$ $7.18(\mathrm{~m}, 4 \mathrm{H}), 2.46(\mathrm{~s}, 3 \mathrm{H}), 2.36(\mathrm{~s}, 3 \mathrm{H})$.

${ }^{13}$ C-NMR $\left(\mathrm{CDCl}_{3}, 126 \mathrm{MHz}\right): \delta=153.1\left(\mathrm{C}_{\mathrm{q}}\right), 149.8\left(\mathrm{C}_{\mathrm{q}}\right), 139.3\left(\mathrm{C}_{\mathrm{q}}\right), 138.8\left(\mathrm{C}_{\mathrm{q}}\right), 137.1\left(\mathrm{C}_{\mathrm{q}}\right)$, $135.1\left(\mathrm{C}_{\mathrm{q}}\right), 131.5(\mathrm{CH}), 131.3(\mathrm{CH}), 131.1(\mathrm{CH}), 130.5\left(\mathrm{C}_{\mathrm{q}}\right), 128.8(\mathrm{CH}), 127.7\left(\mathrm{C}_{\mathrm{q}}\right), 125.8$ $(\mathrm{CH}), 124.5(\mathrm{CH}), 123.9(\mathrm{CH}), 123.1(\mathrm{CH}), 120.3(\mathrm{CH}), 116.1(\mathrm{CH}), 109.9(\mathrm{CH}), 103.1(\mathrm{CH})$, $21.3\left(\mathrm{CH}_{3}\right), 21.1\left(\mathrm{CH}_{3}\right)$.

IR (ATR): 3089, 3025, 2913, 2855, 1607, 1494, 1480, 1190, 1082, 861, 824, 783, 741, $684 \mathrm{~cm}^{-1}$.

MS (EI) $m / z$ (relative intensity): 325 ([M $\left.\mathrm{M}^{+}\right]$100), 219 (25), 204 (21), 191 (27), 179 (48), 91 (21).

HR-MS (EI) $m / z$ for $\mathrm{C}_{22} \mathrm{H}_{19} \mathrm{~N}_{3}\left[\mathbf{M}^{+}\right]$ calcd.: 325.1579 .

found: 325.1580 . 
Synthesis of $(E)-1-\{2-(B e n z o[d][1,3]$ dioxol-5-yl)-5-methylphenyl $\}-2-(m$-tolyl)diazene (83aq)

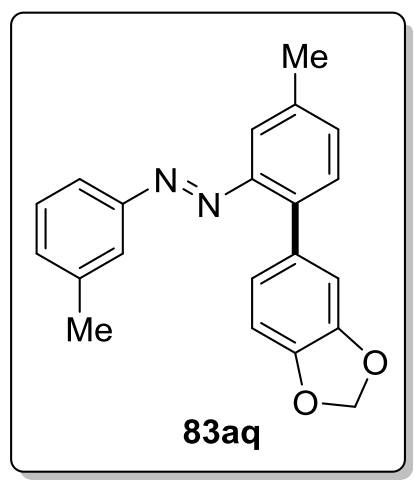

The general procedure D was followed using 13a $(210 \mathrm{mg}, 1.00 \mathrm{mmol})$ and 5-bromobenzo $[d][1,3]$ dioxole $\quad \mathbf{( 5 2 q}) \quad(101 \mathrm{mg}, \quad 0.50 \mathrm{mmol})$. Purification by column chromatography ( $n$-hexane/ $\mathrm{CH}_{2} \mathrm{Cl}_{2}: 7 / 3$ ) yielded 83aq (122 mg, 74\%) as an orange solid.

M. p.: $131-132{ }^{\circ} \mathrm{C}$.

${ }^{1} \mathbf{H}-\mathbf{N M R}\left(\mathrm{CDCl}_{3}, 500 \mathrm{MHz}\right): \delta=7.63(\mathrm{~d}, J=0.7 \mathrm{~Hz}, 1 \mathrm{H}), 7.61(\mathrm{dd}, J=7.9,0.7 \mathrm{~Hz}, 1 \mathrm{H})$, $7.50(\mathrm{~d}, J=0.7 \mathrm{~Hz}, 1 \mathrm{H}), 7.43(\mathrm{~d}, J=7.9 \mathrm{~Hz}, 1 \mathrm{H}), 7.36(\mathrm{dd}, J=7.8,7.8 \mathrm{~Hz}, 1 \mathrm{H}), 7.32$ (ddd, $J=7.8,1.9,0.7 \mathrm{~Hz}, 1 \mathrm{H}), 7.25(\mathrm{ddd}, J=7.8,1.9,0.7 \mathrm{~Hz}, 1 \mathrm{H}), 6.99(\mathrm{dd}, J=1.6,0.7 \mathrm{~Hz}, 1 \mathrm{H})$, $6.87(\mathrm{~d}, J=1.6 \mathrm{~Hz}, 1 \mathrm{H}), 6.86(\mathrm{~d}, J=0.7 \mathrm{~Hz}, 1 \mathrm{H}), 6.00(\mathrm{~s}, 2 \mathrm{H}), 2.44(\mathrm{~s}, 3 \mathrm{H}), 2.41(\mathrm{~s}, 3 \mathrm{H})$.

${ }^{13} \mathbf{C}-\mathrm{NMR}\left(\mathrm{CDCl}_{3}, 126 \mathrm{MHz}\right): \delta=153.1\left(\mathrm{C}_{\mathrm{q}}\right), 149.7\left(\mathrm{C}_{\mathrm{q}}\right), 147.3\left(\mathrm{C}_{\mathrm{q}}\right), 147.0\left(\mathrm{C}_{\mathrm{q}}\right), 139.0\left(\mathrm{C}_{\mathrm{q}}\right)$, $137.9\left(\mathrm{C}_{\mathrm{q}}\right), 137.8\left(\mathrm{C}_{\mathrm{q}}\right), 132.8\left(\mathrm{C}_{\mathrm{q}}\right), 131.6(\mathrm{CH}), 131.5(\mathrm{CH}), 130.6(\mathrm{CH}), 128.9(\mathrm{CH}), 124.8$ $(\mathrm{CH}), 124.0(\mathrm{CH}), 120.3(\mathrm{CH}), 116.3(\mathrm{CH}), 111.3(\mathrm{CH}), 107.6(\mathrm{CH}), 101.1\left(\mathrm{CH}_{2}\right), 21.3$ $\left(\mathrm{CH}_{3}\right), 21.0\left(\mathrm{CH}_{3}\right)$.

IR (ATR): 2914, 1475, 1338, 1217, 1035, 935, 801, 686, 637, $530 \mathrm{~cm}^{-1}$.

MS (EI) $\mathrm{m} / z$ (relative intensity): 330 ([ $\left.\mathrm{M}^{+}\right]$60), 329 (100), 224 (29), 181 (29), 153 (53), 91 (44), 65 (16), 43 (15).

HR-MS (EI) $m / z$ for $\mathrm{C}_{21} \mathrm{H}_{18} \mathrm{~N}_{2} \mathrm{O}_{2}\left[\mathbf{M}^{+}\right]$ calcd.: 330.1368 . found: 330.1360 . 


\section{Synthesis of (E)-3-\{4-Methyl-2-(m-tolyldiazenyl)phenyl\}pyridine (83ar)}

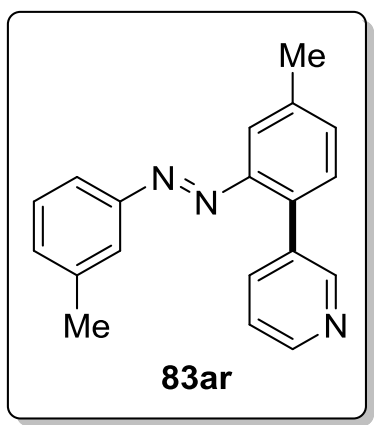

The general procedure $\mathbf{D}$ was followed using 13a (210 mg, $1.00 \mathrm{mmol})$ and 3-bromopyridine (52r) (79 mg, $0.50 \mathrm{mmol}$ ). Purification by column chromatography ( $n$-hexane/EtOAc/ $\mathrm{NEt}_{3}$ : 88/6/6) yielded 83ar (45 mg, 31\%) as an orange solid.

M. p.: $107-108^{\circ} \mathrm{C}$.

${ }^{1} \mathbf{H}$-NMR $\left(\mathrm{CDCl}_{3}, 400 \mathrm{MHz}\right): \delta=8.73(\mathrm{dd}, J=2.4,0.7 \mathrm{~Hz}, 1 \mathrm{H}), 8.58(\mathrm{dd}, J=4.9,1.7 \mathrm{~Hz}$, 1H), 7.75 (ddd, $J=7.9,2.4,1.7 \mathrm{~Hz}, 1 \mathrm{H}), 7.61-7.57(\mathrm{~m}, 2 \mathrm{H}), 7.56(\mathrm{dd}, J=7.8,0.7 \mathrm{~Hz}, 1 \mathrm{H})$, $7.45(\mathrm{~d}, J=7.8 \mathrm{~Hz}, 1 \mathrm{H}), 7.38(\mathrm{ddd}, J=7.8,1.8,0.7 \mathrm{~Hz}, 1 \mathrm{H}), 7.35-7.31$ (m, 2H), 7.25 (ddd, $J=7.8,1.8,0.7 \mathrm{~Hz}, 1 \mathrm{H}), 2.47(\mathrm{~s}, 3 \mathrm{H}), 2.39$ (s, 3H).

${ }^{13} \mathbf{C}-\mathbf{N M R}\left(\mathrm{CDCl}_{3}, 126 \mathrm{MHz}\right): \delta=152.8\left(\mathrm{C}_{\mathrm{q}}\right), 151.0(\mathrm{CH}), 149.4\left(\mathrm{C}_{\mathrm{q}}\right), 148.1(\mathrm{CH}), 139.1$ $\left(\mathrm{C}_{\mathrm{q}}\right), 139.0\left(\mathrm{C}_{\mathrm{q}}\right), 137.9(\mathrm{CH}), 135.1\left(\mathrm{C}_{\mathrm{q}}\right), 134.6\left(\mathrm{C}_{\mathrm{q}}\right), 132.0(\mathrm{CH}), 131.9(\mathrm{CH}), 130.5(\mathrm{CH})$, $128.9(\mathrm{CH}), 124.1(\mathrm{CH}), 122.5(\mathrm{CH}), 120.1(\mathrm{CH}), 116.3(\mathrm{CH}), 21.3\left(\mathrm{CH}_{3}\right), 21.2\left(\mathrm{CH}_{3}\right)$.

IR (ATR): 3023, 2917, 1412, 997, 829, 799, 709, 689, 626, $487 \mathrm{~cm}^{-1}$.

MS (EI) $m / z$ (relative intensity): 287 ([M+ $]$ 63), 286 (81), 168 (76), 91 (100), 65 (35), 43 (58).

HR-MS (EI) $m / z$ for $\mathbf{C}_{19} \mathrm{H}_{17} \mathrm{~N}_{3}\left[\mathbf{M}^{+}\right]$

calcd.: 287.1422 .

found: 287.1409 . 


\section{Synthesis of $(E)-5-\{4-M e t h y l-2-(m$-tolyldiazenyl)phenyl\}pyrimidine (83as)}

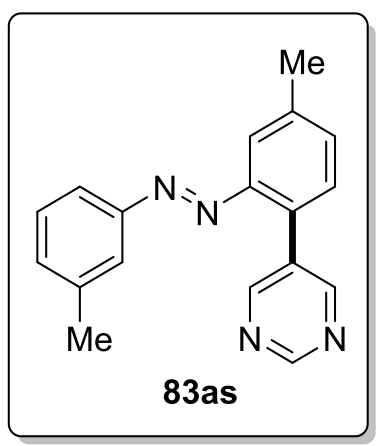

The general procedure D was followed using 13a $(210 \mathrm{mg}, 1.00 \mathrm{mmol})$ and 5-bromopyrimidine (52s) $(79 \mathrm{mg}, 0.50 \mathrm{mmol})$. Purification by column chromatography ( $n$-hexane/EtOAc/NEt 3 : 88/6/6) yielded 83as (40 mg, 28\%) as an orange solid.

M. p.: $126-127^{\circ} \mathrm{C}$.

${ }^{1} \mathbf{H}-\mathbf{N M R}\left(\mathrm{CDCl}_{3}, 400 \mathrm{MHz}\right): \delta=9.18(\mathrm{~s}, 1 \mathrm{H}), 8.85$ (s, 2H), 7.67 (d, $\left.J=0.7 \mathrm{~Hz}, 1 \mathrm{H}\right), 7.59$ (d, $J=0.7 \mathrm{~Hz}, 1 \mathrm{H}), 7.56(\mathrm{ddd}, J=7.7,1.9,0.7 \mathrm{~Hz}, 1 \mathrm{H}), 7.45(\mathrm{~d}, J=7.8 \mathrm{~Hz}, 1 \mathrm{H}), 7.42$ (dd, $J=7.8,0.7 \mathrm{~Hz}, 1 \mathrm{H}), 7.34(\mathrm{dd}, J=7.7,7.7 \mathrm{~Hz}, 1 \mathrm{H}), 7.26(\mathrm{ddd}, J=7.7,1.9,0.7 \mathrm{~Hz}, 1 \mathrm{H}), 2.48$ $(\mathrm{s}, 3 \mathrm{H}), 2.40(\mathrm{~s}, 3 \mathrm{H})$.

${ }^{13} \mathbf{C}-N M R\left(\mathrm{CDCl}_{3}, 126 \mathrm{MHz}\right): \delta=157.5(\mathrm{CH}), 157.0(\mathrm{CH}), 152.7\left(\mathrm{C}_{\mathrm{q}}\right), 149.2\left(\mathrm{C}_{\mathrm{q}}\right), 140.2$ $\left(\mathrm{C}_{\mathrm{q}}\right), 139.1\left(\mathrm{C}_{\mathrm{q}}\right), 132.6\left(\mathrm{C}_{\mathrm{q}}\right), 132.4(\mathrm{CH}), 132.3(\mathrm{CH}), 131.7\left(\mathrm{C}_{\mathrm{q}}\right), 130.1(\mathrm{CH}), 129.1(\mathrm{CH})$, $124.2(\mathrm{CH}), 120.1(\mathrm{CH}), 116.5(\mathrm{CH}), 21.4\left(\mathrm{CH}_{3}\right), 21.3\left(\mathrm{CH}_{3}\right)$.

IR (ATR): 3052, 2918, 1547, 1410, 999, 825, 786, 722, 686, $532 \mathrm{~cm}^{-1}$.

MS (EI) $m / z$ (relative intensity): 288 ([ $\left[\mathrm{M}^{+}\right]$29), 261 (35), 142 (29), 115 (32), 91 (100), 65 (35), 43 (86).

HR-MS (EI) $m / z$ for $\mathrm{C}_{18} \mathrm{H}_{16} \mathrm{~N}_{4}\left[\mathbf{M}^{+}\right]$

calcd.: 288.1375 .

found: 288.1371 . 
Synthesis of Methyl $(E)-2$ '-\{(3,5-dimethylphenyl)diazenyl $\}-4$ '-methyl-[1,1'-biphenyl]4-carboxylate (83la)

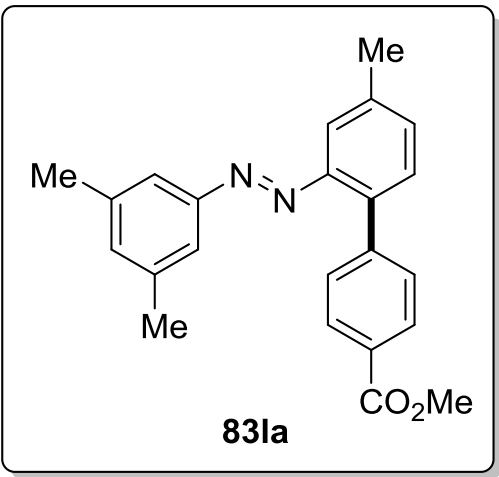

The general procedure D was followed using 131 (224 mg, $1.00 \mathrm{mmol})$ and methyl 4-bromobenzoate $\mathbf{( 5 2 a )}(108 \mathrm{mg}, 0.50 \mathrm{mmol})$. Purification by column chromatography ( $n$-hexane/ $\mathrm{CH}_{2} \mathrm{Cl}_{2}: 7 / 3$ ) yielded 83la (168 $\mathrm{mg}, 94 \%$ ) as an orange solid.

M. p.: $159-160^{\circ} \mathrm{C}$

${ }^{1} \mathbf{H}-\mathbf{N M R}\left(\mathrm{CDCl}_{3}, 500 \mathrm{MHz}\right): \delta=8.08(\mathrm{~d}, J=8.5 \mathrm{~Hz}, 2 \mathrm{H}), 7.54-7.51(\mathrm{~m}, 3 \mathrm{H}), 7.46(\mathrm{~d}$, $J=7.8 \mathrm{~Hz}, 1 \mathrm{H}), 7.39$ (s, 2H), 7.35 (dd, $J=7.8,1.2 \mathrm{~Hz}, 1 \mathrm{H}), 7.10-7.07$ (m, 1H), $3.94(\mathrm{~s}, 3 \mathrm{H})$, $2.46(\mathrm{~s}, 3 \mathrm{H}), 2.35(\mathrm{~s}, 6 \mathrm{H})$.

${ }^{13} \mathrm{C}-\mathrm{NMR}\left(\mathrm{CDCl}_{3}, 126 \mathrm{MHz}\right): \delta=167.2\left(\mathrm{C}_{\mathrm{q}}\right), 153.0\left(\mathrm{C}_{\mathrm{q}}\right), 149.6\left(\mathrm{C}_{\mathrm{q}}\right), 143.7\left(\mathrm{C}_{\mathrm{q}}\right), 138.9\left(\mathrm{C}_{\mathrm{q}}\right)$, $138.7\left(\mathrm{C}_{\mathrm{q}}\right), 137.0\left(\mathrm{C}_{\mathrm{q}}\right), 132.7(\mathrm{CH}), 131.5(\mathrm{CH}), 130.8(\mathrm{CH}), 130.5(\mathrm{CH}), 128.8(\mathrm{CH}), 128.6$ $\left(\mathrm{C}_{\mathrm{q}}\right), 121.0(\mathrm{CH}), 116.3(\mathrm{CH}), 52.1\left(\mathrm{CH}_{3}\right), 21.3\left(\mathrm{CH}_{3}\right), 21.2\left(\mathrm{CH}_{3}\right)$.

IR (ATR): 2951, 2915, 2854, 1720, 1606, 1438, 1278, 1105, 859, 829, 775, $686 \mathrm{~cm}^{-1}$.

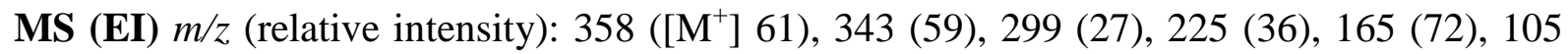
(100), $77(25)$.

HR-MS (ESI) $m / z$ for $\mathrm{C}_{23} \mathrm{H}_{22} \mathrm{~N}_{2} \mathrm{O}_{2}\left[\mathrm{M}+\mathrm{H}^{+}\right]$ calcd.: 359.1754 . found: 359.1754 . 
Synthesis of Methyl 2'-amino-4'-methyl-[1,1'-biphenyl]-4-carboxylate (34aa)

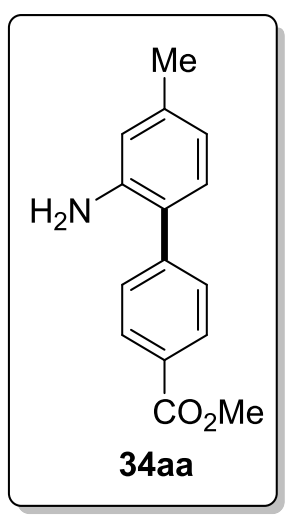

The general procedure $\mathbf{E}$ was followed using 13a $(210 \mathrm{mg}, 1.00 \mathrm{mmol})$, methyl 4-bromobenzoate (52a) (108 mg, $0.50 \mathrm{mmol}), \mathrm{Zn}(164 \mathrm{mg}, 2.50 \mathrm{mmol})$ and $\mathrm{HCl}(0.40 \mathrm{~mL})$. Purification by column chromatography ( $n$-hexane/EtOAc: $5 / 1$ ) yielded 34aa (101 mg, 84\%) as a colorless solid.

M. p.: $136-137^{\circ} \mathrm{C}$.

${ }^{1} \mathbf{H}-\mathbf{N M R}\left(\mathrm{CDCl}_{3}, 300 \mathrm{MHz}\right): \delta=8.08(\mathrm{~d}, J=8.6 \mathrm{~Hz}, 2 \mathrm{H}), 7.52(\mathrm{~d}, J=8.6 \mathrm{~Hz}, 2 \mathrm{H}), 7.02(\mathrm{~d}$, $J=7.7 \mathrm{~Hz}, 1 \mathrm{H}), 6.65(\mathrm{ddd}, J=7.7,1.6,0.7 \mathrm{~Hz}, 1 \mathrm{H}), 6.59$ (s, 1H), $3.92(\mathrm{~s}, 3 \mathrm{H}), 3.71(\mathrm{~s}, 2 \mathrm{H})$, $2.30(\mathrm{~s}, 3 \mathrm{H})$.

${ }^{13} \mathrm{C}-\mathrm{NMR}\left(\mathrm{CDCl}_{3}, 126 \mathrm{MHz}\right): \delta=166.9\left(\mathrm{C}_{\mathrm{q}}\right), 144.5\left(\mathrm{C}_{\mathrm{q}}\right), 143.2\left(\mathrm{C}_{\mathrm{q}}\right), 139.2\left(\mathrm{C}_{\mathrm{q}}\right), 130.2(\mathrm{CH})$, $130.0(\mathrm{CH}), 129.0(\mathrm{CH}), 128.6\left(\mathrm{C}_{\mathrm{q}}\right), 123.7\left(\mathrm{C}_{\mathrm{q}}\right), 119.8(\mathrm{CH}), 116.5(\mathrm{CH}), 52.1\left(\mathrm{CH}_{3}\right), 21.2$ $\left(\mathrm{CH}_{3}\right)$.

IR (ATR): 3442, 3360, 2947, 2915, 2164, 1703, 1604, 1435, 1280, 1178, 1103, $772 \mathrm{~cm}^{-1}$.

MS (EI) $m / z$ (relative intensity): $241\left(\left[\mathrm{M}^{+}\right]\right.$100), 210 (31), 167 (35), 84 (24), 49 (38).

HR-MS (EI) $m / z$ for $\mathrm{C}_{15} \mathrm{H}_{15} \mathrm{NO}_{2}\left[\mathbf{M}^{+}\right]$ calcd.: 241.1103. found: 241.1109 . 


\section{Synthesis of $N 4^{\prime}, N 4$ ',4-Trimethyl-[1,1'-biphenyl]-2,4'-diamine (34ae)}

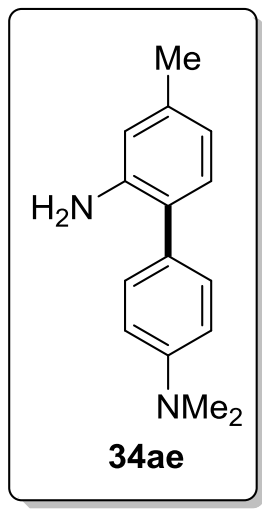

The general procedure $\mathbf{E}$ was followed using 13a $(210 \mathrm{mg}, 1.00 \mathrm{mmol})$, 4-bromo- $N, N$ dimethylaniline (52e) (100 mg, $0.50 \mathrm{mmol}), \mathrm{Zn}(164 \mathrm{mg}, 2.50 \mathrm{mmol})$ and $\mathrm{HCl}(0.40 \mathrm{~mL})$. Purification by column chromatography ( $n$-hexane/EtOAc: $1 / 1)$ yielded 34ae (59 $\mathrm{mg}, 52 \%$ ) as a colorless solid.

M. p.: $122-123^{\circ} \mathrm{C}$.

${ }^{1}$ H-NMR $\left(\mathrm{CDCl}_{3}, 500 \mathrm{MHz}\right): \delta=7.31(\mathrm{~d}, J=8.8 \mathrm{~Hz}, 2 \mathrm{H}), 7.00(\mathrm{~d}, J=7.6 \mathrm{~Hz}, 1 \mathrm{H}), 6.81(\mathrm{~d}$, $J=8.8 \mathrm{~Hz}, 2 \mathrm{H}), 6.62(\mathrm{ddd}, J=7.6,1.5,0.6 \mathrm{~Hz}, 1 \mathrm{H}), 6.58(\mathrm{~s}, 1 \mathrm{H}), 3.65(\mathrm{~s}, 2 \mathrm{H}), 2.97$ (s, 6H), $2.28(\mathrm{~s}, 3 \mathrm{H})$.

${ }^{13}$ C-NMR $\left(\mathrm{CDCl}_{3}, 126 \mathrm{MHz}\right): \delta=149.4\left(\mathrm{C}_{\mathrm{q}}\right), 143.5\left(\mathrm{C}_{\mathrm{q}}\right), 137.6\left(\mathrm{C}_{\mathrm{q}}\right), 130.3(\mathrm{CH}), 129.8$ $(\mathrm{CH}), 127.6\left(\mathrm{C}_{\mathrm{q}}\right), 125.2\left(\mathrm{C}_{\mathrm{q}}\right), 119.5(\mathrm{CH}), 116.2(\mathrm{CH}), 112.9(\mathrm{CH}), 40.7\left(\mathrm{CH}_{3}\right), 21.2\left(\mathrm{CH}_{3}\right)$.

IR (ATR): 3443, 3360, 2917, 1605, 1527, 1499, 1219, 1060, 944, $802 \mathrm{~cm}^{-1}$.

MS (EI) $m / z$ (relative intensity): 226 ([ $\left.\mathrm{M}^{+}\right]$100), 211 (14), 182 (12), 113 (10).

HR-MS (EI) $m / z$ for $\mathrm{C}_{15} \mathrm{H}_{18} \mathrm{~N}_{2}\left[\mathbf{M}^{+}\right]$

calcd.: 226.1470 .

found: 226.1465 . 


\section{Synthesis of 2'-Amino-4'-methyl-[1,1'-biphenyl]-4-carbonitrile (34ai)}

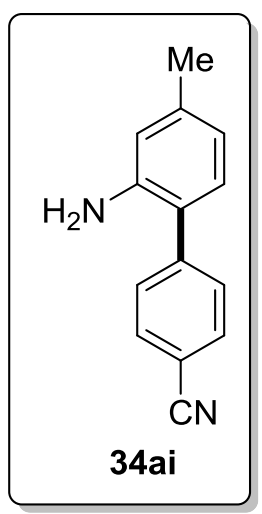

The general procedure $\mathbf{E}$ was followed using 13a $(210 \mathrm{mg}, 1.00 \mathrm{mmol})$, 4-bromobenzonitrile (52i) $(91 \mathrm{mg}, 0.50 \mathrm{mmol}), \mathrm{Zn}(164 \mathrm{mg}, 2.50 \mathrm{mmol})$ and $\mathrm{HCl}(0.40 \mathrm{~mL})$. Purification by column chromatography ( $n$-hexane/EtOAc: 5/1) yielded 34ai $(64 \mathrm{mg}, 61 \%)$ as a colorless solid.

M. p.: $121-122^{\circ} \mathrm{C}$.

${ }^{1} \mathbf{H}-\mathbf{N M R}\left(\mathrm{CDCl}_{3}, 500 \mathrm{MHz}\right): \delta=7.69(\mathrm{~d}, J=8.6 \mathrm{~Hz}, 2 \mathrm{H}), 7.57(\mathrm{~d}, J=8.6 \mathrm{~Hz}, 2 \mathrm{H}), 6.98(\mathrm{~d}$, $J=7.7 \mathrm{~Hz}, 1 \mathrm{H}), 6.66(\mathrm{ddd}, J=7.7,1.6,0.7 \mathrm{~Hz}, 1 \mathrm{H}), 6.60(\mathrm{~s}, 1 \mathrm{H}), 3.75(\mathrm{~s}, 2 \mathrm{H}), 2.30(\mathrm{~s}, 3 \mathrm{H})$.

${ }^{13}$ C-NMR $\left(\mathrm{CDCl}_{3}, 126 \mathrm{MHz}\right): \delta=144.6\left(\mathrm{C}_{\mathrm{q}}\right), 143.0\left(\mathrm{C}_{\mathrm{q}}\right), 139.7\left(\mathrm{C}_{\mathrm{q}}\right), 132.5(\mathrm{CH}), 130.1$ $(\mathrm{CH}), 129.8(\mathrm{CH}), 122.8\left(\mathrm{C}_{\mathrm{q}}\right), 120.1(\mathrm{CH}), 118.9\left(\mathrm{C}_{\mathrm{q}}\right), 116.7(\mathrm{CH}), 110.5\left(\mathrm{C}_{\mathrm{q}}\right), 21.2\left(\mathrm{CH}_{3}\right)$.

IR (ATR): 3441, 3363, 2297, 2228, 1618, 1512, 1490, 1399, 1170, 1003, $843 \mathrm{~cm}^{-1}$.

MS (EI) $m / z$ (relative intensity): $208\left(\left[\mathrm{M}^{+}\right]\right.$100), 192 (19), 43 (10).

HR-MS (EI) $m / z$ for $\mathrm{C}_{14} \mathrm{H}_{12} \mathrm{~N}_{2}\left[\mathbf{M}^{+}\right]$

calcd.: 208.1000.

found: 208.0999 . 


\section{Synthesis of 3',4',5'-Trimethoxy-4-methyl-[1,1'-biphenyl]-2-amine (34al)}

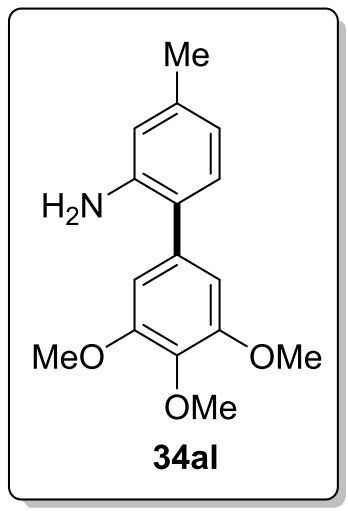

The general procedure $\mathbf{E}$ was followed using 13a $(210 \mathrm{mg}, 1.00 \mathrm{mmol})$, 5-bromo-1,2,3trimethoxybenzene (52l) $(124 \mathrm{mg}, 0.50 \mathrm{mmol}), \mathrm{Zn}(164 \mathrm{mg}, 2.50 \mathrm{mmol})$ and $\mathrm{HCl}(0.40 \mathrm{~mL})$. Purification by column chromatography ( $n$-hexane/EtOAc: $1 / 1)$ yielded 34al $(115 \mathrm{mg}, 84 \%)$ as a colorless solid.

M. p.: $136-137^{\circ} \mathrm{C}$.

${ }^{1}$ H-NMR $\left(\mathrm{CDCl}_{3}, 500 \mathrm{MHz}\right): \delta=7.02(\mathrm{~d}, J=7.6 \mathrm{~Hz}, 1 \mathrm{H}), 6.64(\mathrm{~s}, 2 \mathrm{H}), 6.63(\mathrm{dd}, J=7.7$, $0.6 \mathrm{~Hz}, 1 \mathrm{H}), 6.59$ (s, 1H), 3.88 (s, 3H), 3.85 (s, 6H), 3.73 (s, 2H), 2.29 (s, 3H).

${ }^{13}$ C-NMR $\left(\mathrm{CDCl}_{3}, 126 \mathrm{MHz}\right): \delta=153.3\left(\mathrm{C}_{\mathrm{q}}\right), 143.2\left(\mathrm{C}_{\mathrm{q}}\right), 138.4\left(\mathrm{C}_{\mathrm{q}}\right), 136.9\left(\mathrm{C}_{\mathrm{q}}\right), 135.0\left(\mathrm{C}_{\mathrm{q}}\right)$, $130.0(\mathrm{CH}), 124.9\left(\mathrm{C}_{\mathrm{q}}\right), 119.4(\mathrm{CH}), 116.2(\mathrm{CH}), 106.1(\mathrm{CH}), 60.8\left(\mathrm{CH}_{3}\right), 56.1\left(\mathrm{CH}_{3}\right), 21.1$ $\left(\mathrm{CH}_{3}\right)$.

IR (ATR): 3421, 3350, 2960, 2834, 1583, 1449, 1237, 1117, 1025, $834 \mathrm{~cm}^{-1}$.

MS (EI) $\mathrm{m} / z$ (relative intensity): 273 ([M+ $]$ 100), 258 (71), 198 (14), 144 (16), 43 (12).

HR-MS (EI) $m / z$ for $\mathrm{C}_{16} \mathrm{H}_{19} \mathrm{NO}_{3}\left[\mathrm{M}^{+}\right] \quad$ calcd.: 273.1365 .

found: 273.1372 . 


\section{Synthesis of 3',4'-Dichloro-4-methyl-[1,1'-biphenyl]-2-amine (34am)}

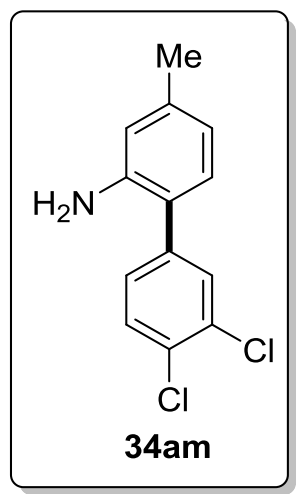

The general procedure $\mathbf{E}$ was followed using 13a $(210 \mathrm{mg}, 1.00 \mathrm{mmol})$, 4-bromo-1,2dichlorobenzene (52m) (113 mg, $0.50 \mathrm{mmol}), \mathrm{Zn}(164 \mathrm{mg}, 2.50 \mathrm{mmol})$ and $\mathrm{HCl}(0.40 \mathrm{~mL})$. Purification by column chromatography ( $n$-hexane/EtOAc: $5 / 1$ ) yielded 34am (76 mg, 60\%) as a colorless solid.

M. p.: $125-126^{\circ} \mathrm{C}$.

${ }^{1}$ H-NMR (DMSO-d $\left.{ }_{6}, 300 \mathrm{MHz}\right): \delta=7.64(\mathrm{~d}, J=8.3 \mathrm{~Hz}, 1 \mathrm{H}), 7.59(\mathrm{~d}, J=2.1 \mathrm{~Hz}, 1 \mathrm{H}), 7.37$ $(\mathrm{dd}, J=8.3,2.1 \mathrm{~Hz}, 1 \mathrm{H}), 6.88(\mathrm{~d}, J=7.8 \mathrm{~Hz}, 1 \mathrm{H}), 6.58$ (s, 1H), 6.46 (ddd, $J=7.8,1.3$, $0.6 \mathrm{~Hz}, 1 \mathrm{H}), 4.82$ (s, 2H), 2.19 (s, 3H).

${ }^{13}$ C-NMR (DMSO-d $\left.6,126 \mathrm{MHz}\right): \delta=144.9\left(\mathrm{C}_{\mathrm{q}}\right), 140.5\left(\mathrm{C}_{\mathrm{q}}\right), 138.1\left(\mathrm{C}_{\mathrm{q}}\right), 131.1\left(\mathrm{C}_{\mathrm{q}}\right), 130.6$ $(\mathrm{CH}), 130.4(\mathrm{CH}), 129.8(\mathrm{CH}), 129.0(\mathrm{CH}), 128.9\left(\mathrm{C}_{\mathrm{q}}\right), 120.5\left(\mathrm{C}_{\mathrm{q}}\right), 117.8(\mathrm{CH}), 116.0(\mathrm{CH})$, $20.8\left(\mathrm{CH}_{3}\right)$.

IR (ATR): 3462, 3376, 2922, 2853, 1616, 1465, 1373, 1132, 1029, $827 \mathrm{~cm}^{-1}$.

MS (EI) $m / z$ (relative intensity): 251 ([M+ $]$ 100), 215 (24), 181 (35), 84 (27), 58 (18).

HR-MS (EI) $m / z$ for $\mathrm{C}_{13} \mathrm{H}_{11} \mathrm{Cl}_{2} \mathrm{~N}\left[\mathrm{M}^{+}\right] \quad$ calcd.: 251.0269. found: 251.0264 . 
Synthesis of Methyl 2'-(1-benzyl-1H-tetrazol-5-yl)-[1,1'-biphenyl]-4-carboxylate (69aa) and Dimethyl 2'-(1-benzyl-1H-tetrazol-5-yl)-[1,1':3',1"'-terphenyl]-4,4"'-dicarboxylate (69aa')

The general procedure $\mathbf{F}$ was followed using 68a $(70.9 \mathrm{mg}, 0.30 \mathrm{mmol})$ and methyl 4-chlorobenzoate (59a) (154 mg, $0.90 \mathrm{mmol})$. Purification by column chromatography (n-hexane/EtOAc: 4/1) yielded 69aa (86 mg, 77\%) and 69aa' (15 mg, 10\%) as colorless solids.

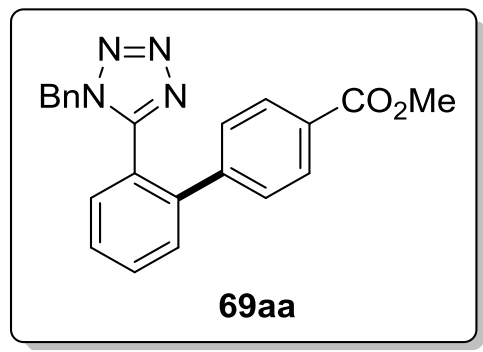

M. p.: $109-110{ }^{\circ} \mathrm{C}$.

${ }^{1} \mathbf{H}-\mathbf{N M R}\left(\mathrm{CDCl}_{3}, 500 \mathrm{MHz}\right): 7.90(\mathrm{~d}, J=8.4 \mathrm{~Hz}, 2 \mathrm{H}), 7.64(\mathrm{ddd}, J=7.6,7.6,1.4 \mathrm{~Hz}, 1 \mathrm{H})$, $7.56(\mathrm{dd}, J=7.9,0.9 \mathrm{~Hz}, 1 \mathrm{H}), 7.46(\mathrm{ddd}, J=7.6,7.6,1.4 \mathrm{~Hz}, 1 \mathrm{H}), 7.35$ (dd, $J=7.9,0.9 \mathrm{~Hz}$, 1H), 7.19 (tt, $J=7.4,1.8 \mathrm{~Hz}, 1 \mathrm{H}), 7.15-7.10(\mathrm{~m}, 4 \mathrm{H}), 6.75$ (d, $J=8.4 \mathrm{~Hz}, 2 \mathrm{H}), 4.83$ (s, 2H), $3.90(\mathrm{~s}, 3 \mathrm{H})$.

${ }^{13}$ C-NMR $\left(\mathrm{CDCl}_{3}, 126 \mathrm{MHz}\right): \delta=166.4\left(\mathrm{C}_{\mathrm{q}}\right), 154.2\left(\mathrm{C}_{\mathrm{q}}\right), 143.2\left(\mathrm{C}_{\mathrm{q}}\right), 140.7\left(\mathrm{C}_{\mathrm{q}}\right), 132.9\left(\mathrm{C}_{\mathrm{q}}\right)$, $131.6(\mathrm{CH}), 131.2(\mathrm{CH}), 130.2(\mathrm{CH}), 130.0(\mathrm{CH}), 129.6\left(\mathrm{C}_{\mathrm{q}}\right), 128.8(\mathrm{CH}), 128.7(\mathrm{CH}), 128.6$ $(\mathrm{CH}), 128.5(\mathrm{CH}), 127.7(\mathrm{CH}), 122.7\left(\mathrm{C}_{\mathrm{q}}\right), 52.3\left(\mathrm{CH}_{3}\right), 50.9\left(\mathrm{CH}_{2}\right)$.

IR (ATR): 2951, 1717, 1435, 1403, 1278, 1103, 1007, 911, 753, $723 \mathrm{~cm}^{-1}$

MS (EI) $m / z$ (relative intensity): 370 ([M+1 19), 369 (58), 341 (14), 164 (17), 91 (100), 65 (14).

HR-MS (ESI) $m / z$ for $\mathrm{C}_{22} \mathrm{H}_{19} \mathrm{~N}_{4} \mathrm{O}_{2}\left[\mathrm{M}+\mathrm{H}^{+}\right]$

calcd.: 371.1503 .

found: 371.1503 . 


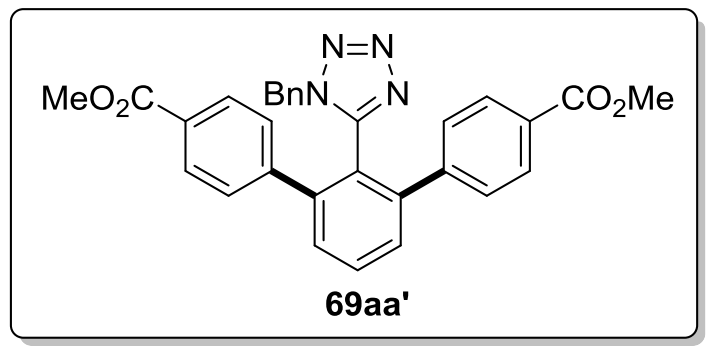

M. p.: $180-181^{\circ} \mathrm{C}$.

${ }^{1} \mathbf{H}-\mathbf{N M R}\left(\mathrm{CDCl}_{3}, 500 \mathrm{MHz}\right): 7.82(\mathrm{~d}, J=8.6 \mathrm{~Hz}, 4 \mathrm{H}), 7.73(\mathrm{t}, J=7.8 \mathrm{~Hz}, 1 \mathrm{H}), 7.52(\mathrm{~d}$, $J=7.8 \mathrm{~Hz}, 2 \mathrm{H}), 7.24(\mathrm{tt}, J=7.8,1.2 \mathrm{~Hz}, 1 \mathrm{H}), 7.13(\mathrm{dd}, J=7.8,7.8 \mathrm{~Hz}, 2 \mathrm{H}), 6.99$ (d, $J=8.6 \mathrm{~Hz}, 4 \mathrm{H}), 6.68(\mathrm{dd}, J=7.8,1.2 \mathrm{~Hz}, 2 \mathrm{H}), 4.69(\mathrm{~s}, 2 \mathrm{H}), 3.88(\mathrm{~s}, 6 \mathrm{H})$.

${ }^{13}$ C-NMR $\left(\mathrm{CDCl}_{3}, 126 \mathrm{MHz}\right): \delta=166.5\left(\mathrm{C}_{\mathrm{q}}\right), 152.3\left(\mathrm{C}_{\mathrm{q}}\right), 143.1\left(\mathrm{C}_{\mathrm{q}}\right), 142.7\left(\mathrm{C}_{\mathrm{q}}\right), 132.3\left(\mathrm{C}_{\mathrm{q}}\right)$, $131.5(\mathrm{CH}), 130.0(\mathrm{CH}), 129.6(\mathrm{CH}), 129.5\left(\mathrm{C}_{\mathrm{q}}\right), 129.0(\mathrm{CH}), 128.9(\mathrm{CH}), 128.8(\mathrm{CH}), 128.1$ $(\mathrm{CH}), 121.3\left(\mathrm{C}_{\mathrm{q}}\right), 52.2\left(\mathrm{CH}_{3}\right), 50.8\left(\mathrm{CH}_{2}\right)$.

IR (ATR): 2951, 1719, 1433, 1271, 1100, 1017, 864, 769, 721, $704 \mathrm{~cm}^{-1}$.

MS (EI) $m / z$ (relative intensity): 504 ([M+] 44), 503 (51), 325 (23), 239 (27), 91 (100), 58 (33).

HR-MS (ESI) $m / z$ for $\mathrm{C}_{30} \mathrm{H}_{25} \mathrm{~N}_{4} \mathrm{O}_{4}\left[\mathrm{M}+\mathrm{H}^{+}\right]$ calcd.: 505.1870 . found: 505.1868 . 
Synthesis of Methyl 2'-(1-benzyl-1H-tetrazol-5-yl)-4'-methyl-[1,1'-biphenyl]4-carboxylate (69ca)

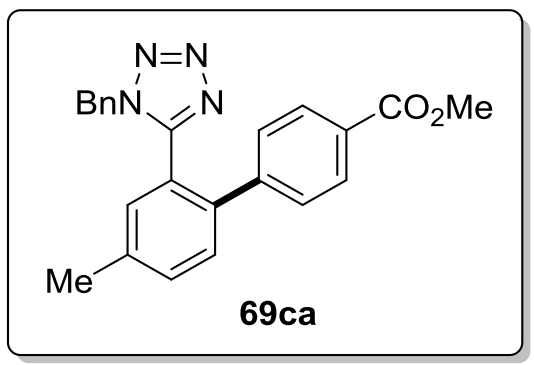

The general procedure $\mathbf{F}$ was followed using $\mathbf{6 8 c}(75.1 \mathrm{mg}, 0.30 \mathrm{mmol})$ and methyl 4-chlorobenzoate (59a) $(154 \mathrm{mg}, 0.90 \mathrm{mmol})$. Purification by column chromatography $\left(\mathrm{CH}_{2} \mathrm{Cl}_{2}\right.$ /EtOAc: $\left.24 / 1\right)$ yielded 69ca (103 mg, 89\%) as a colorless solid.

M. p.: $111-112^{\circ} \mathrm{C}$.

${ }^{1} \mathbf{H}-\mathbf{N M R}\left(\mathrm{CDCl}_{3}, 300 \mathrm{MHz}\right): \delta=7.87(\mathrm{~d}, J=8.4 \mathrm{~Hz}, 2 \mathrm{H}), 7.46-7.39(\mathrm{~m}, 2 \mathrm{H}), 7.21-7.05(\mathrm{~m}$, $6 \mathrm{H}), 6.73(\mathrm{~d}, J=8.4 \mathrm{~Hz}, 2 \mathrm{H}), 4.79(\mathrm{~s}, 2 \mathrm{H}), 3.87(\mathrm{~s}, 3 \mathrm{H}), 2.35(\mathrm{~s}, 3 \mathrm{H})$.

${ }^{13}$ C-NMR $\left(\mathrm{CDCl}_{3}, 126 \mathrm{MHz}\right): \delta=166.3\left(\mathrm{C}_{\mathrm{q}}\right), 154.3\left(\mathrm{C}_{\mathrm{q}}\right), 143.2\left(\mathrm{C}_{\mathrm{q}}\right), 138.6\left(\mathrm{C}_{\mathrm{q}}\right), 137.8\left(\mathrm{C}_{\mathrm{q}}\right)$, $132.9\left(\mathrm{C}_{\mathrm{q}}\right), 132.3(\mathrm{CH}), 131.7(\mathrm{CH}), 130.1(\mathrm{CH}), 129.9(\mathrm{CH}), 129.4\left(\mathrm{C}_{\mathrm{q}}\right), 128.6(\mathrm{CH}), 128.5$ $(\mathrm{CH}), 128.4(\mathrm{CH}), 127.6(\mathrm{CH}), 122.5\left(\mathrm{C}_{\mathrm{q}}\right), 52.2\left(\mathrm{CH}_{3}\right), 50.9\left(\mathrm{CH}_{2}\right), 20.9\left(\mathrm{CH}_{3}\right)$.

IR (ATR): 2951, 1712, 1606, 1434, 1275, 1185, 866, 823, 776, $727 \mathrm{~cm}^{-1}$.

MS (EI) $\mathrm{m} / z$ (relative intensity): 384 ([M+] 27), 383 (71), 355 (19), 178 (15), 91 (100), 65 (14).

HR-MS (EI) $m / z$ for $\mathrm{C}_{23} \mathrm{H}_{20} \mathrm{~N}_{4} \mathrm{O}_{2}\left[\mathrm{M}^{+}\right] \quad$ calcd.: 384.1586 .

found: 384.1574 . 
Synthesis of Methyl 2'-(1-benzyl-1H-tetrazol-5-yl)-5'-methyl-[1,1'-biphenyl]4-carboxylate (69da) and Dimethyl 2'-(1-benzyl-1H-tetrazol-5-yl)-5'-methyl-[1,1':3',1'"terphenyl]-4,4"'-dicarboxylate (69da')

The general procedure $\mathbf{F}$ was followed using $\mathbf{6 8 d}(75.1 \mathrm{mg}, 0.30 \mathrm{mmol})$ and methyl 4-chlorobenzoate (59a) (154 mg, $0.90 \mathrm{mmol})$. Purification by column chromatography $\left(\mathrm{CH}_{2} \mathrm{Cl}_{2}\right.$ /EtOAc: $\left.24 / 1\right)$ yielded 69da (72 mg, 62\%) and 69da' (24 mg, 15\%) as colorless solids.

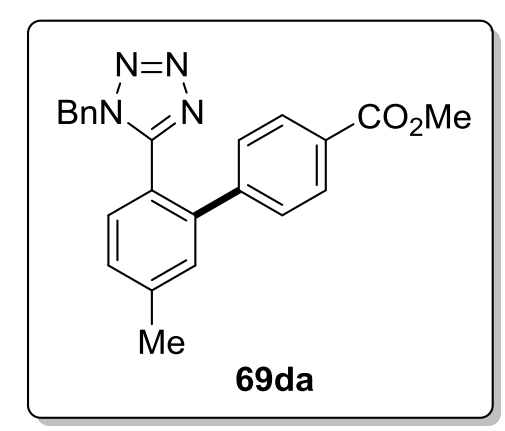

M. p.: $125-126^{\circ} \mathrm{C}$.

${ }^{1} \mathbf{H}-\mathbf{N M R}\left(\mathrm{CDCl}_{3}, 300 \mathrm{MHz}\right): 7.88(\mathrm{~d}, J=8.4 \mathrm{~Hz}, 2 \mathrm{H}), 7.36(\mathrm{~s}, 1 \mathrm{H}), 7.30-7.08(\mathrm{~m}, 7 \mathrm{H}), 7.16$ $(\mathrm{d}, J=8.4 \mathrm{~Hz}, 2 \mathrm{H}), 4.81(\mathrm{~s}, 2 \mathrm{H}), 3.89(\mathrm{~s}, 3 \mathrm{H}), 2.47$ (s, 3H).

${ }^{13} \mathrm{C}-\mathrm{NMR}\left(\mathrm{CDCl}_{3}, 126 \mathrm{MHz}\right): \delta=166.3\left(\mathrm{C}_{\mathrm{q}}\right), 154.2\left(\mathrm{C}_{\mathrm{q}}\right), 143.3\left(\mathrm{C}_{\mathrm{q}}\right), 141.9\left(\mathrm{C}_{\mathrm{q}}\right), 140.5\left(\mathrm{C}_{\mathrm{q}}\right)$, $132.9\left(\mathrm{C}_{\mathrm{q}}\right), 131.0(\mathrm{CH}), 130.9(\mathrm{CH}), 129.9(\mathrm{CH}), 129.5\left(\mathrm{C}_{\mathrm{q}}\right), 129.1(\mathrm{CH}), 128.6(\mathrm{CH}), 128.5$ $(\mathrm{CH}), 128.4(\mathrm{CH}), 127.6(\mathrm{CH}), 119.7\left(\mathrm{C}_{\mathrm{q}}\right), 52.2\left(\mathrm{CH}_{2}\right), 50.8\left(\mathrm{CH}_{3}\right), 21.5\left(\mathrm{CH}_{3}\right)$.

IR (ATR): 2951, 1718, 1435, 1277, 1182, 1102, 859, 823, 721, $705 \mathrm{~cm}^{-1}$.

MS (EI) $m / z$ (relative intensity): 384 ([ $\left.\mathrm{M}^{+}\right]$31), 383 (76), 355 (23), 178 (19), 91 (100), 65 (14), 43 (19).

HR-MS (ESI) $m / z$ for $\mathrm{C}_{23} \mathrm{H}_{21} \mathrm{~N}_{4} \mathrm{O}_{2}\left[\mathrm{M}+\mathrm{H}^{+}\right]$

calcd.: 385.1659 .

found: 385.1663 . 


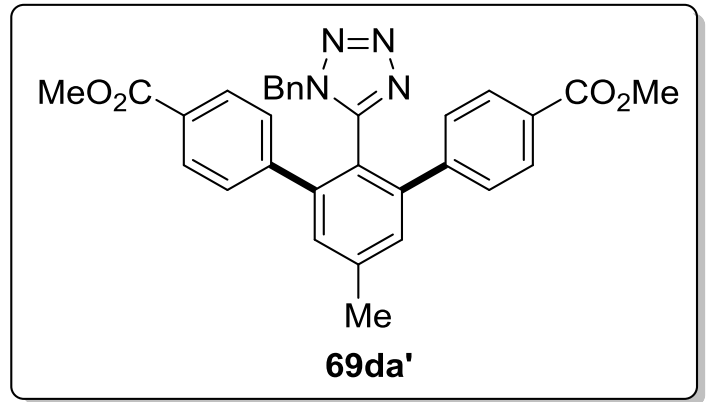

M. p.: $194-195^{\circ} \mathrm{C}$.

${ }^{1} \mathbf{H}-\mathbf{N M R}\left(\mathrm{CDCl}_{3}, 300 \mathrm{MHz}\right): 7.80(\mathrm{~d}, J=8.6 \mathrm{~Hz}, 4 \mathrm{H}), 7.33(\mathrm{~s}, 2 \mathrm{H}), 7.22(\mathrm{tt}, J=7.4,1.4 \mathrm{~Hz}$, 1H), $7.12(\mathrm{dd}, J=7.6,7.6 \mathrm{~Hz}, 2 \mathrm{H}), 6.99(\mathrm{~d}, J=8.6 \mathrm{~Hz}, 4 \mathrm{H}), 6.68(\mathrm{dd}, J=7.8,1.2 \mathrm{~Hz}, 2 \mathrm{H})$, $4.67(\mathrm{~s}, 2 \mathrm{H}), 3.87(\mathrm{~s}, 6 \mathrm{H}), 2.53(\mathrm{~s}, 3 \mathrm{H})$.

${ }^{13} \mathrm{C}-\mathrm{NMR}\left(\mathrm{CDCl}_{3}, 126 \mathrm{MHz}\right): \delta=166.3\left(\mathrm{C}_{\mathrm{q}}\right), 152.3\left(\mathrm{C}_{\mathrm{q}}\right), 143.2\left(\mathrm{C}_{\mathrm{q}}\right), 142.4\left(\mathrm{C}_{\mathrm{q}}\right), 141.7\left(\mathrm{C}_{\mathrm{q}}\right)$, $132.4\left(\mathrm{C}_{\mathrm{q}}\right), 130.6(\mathrm{CH}), 129.4(\mathrm{CH}), 129.3\left(\mathrm{C}_{\mathrm{q}}\right), 128.8(\mathrm{CH}), 128.7(\mathrm{CH}), 128.6(\mathrm{CH}), 127.9$ $(\mathrm{CH}), 118.3\left(\mathrm{C}_{\mathrm{q}}\right), 52.2\left(\mathrm{CH}_{3}\right), 50.7\left(\mathrm{CH}_{2}\right), 21.5\left(\mathrm{CH}_{3}\right)$.

IR (ATR): 2949, 1711, 1610, 1435, 1269, 1183, 1110, 1017, 856, $723 \mathrm{~cm}^{-1}$.

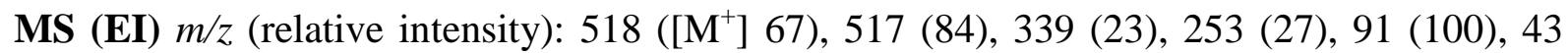
(51).

HR-MS (ESI) $m / z$ for $\mathrm{C}_{31} \mathrm{H}_{27} \mathrm{~N}_{4} \mathrm{O}_{4}\left[\mathrm{M}+\mathrm{H}^{+}\right]$

calcd.: 519.2027 .

found: 519.2015 . 
Synthesis of Methyl 2'-(1-benzyl-1H-tetrazol-5-yl)-4'-methoxy-[1,1'-biphenyl]4-carboxylate (69ea) and Methyl 2'-(1-benzyl-1H-tetrazol-5-yl)-6'-methoxy[1,1'-biphenyl]-4-carboxylate (69ea")

The general procedure $\mathbf{F}$ was followed using $68 \mathrm{e}(79.9 \mathrm{mg}, 0.30 \mathrm{mmol})$ and methyl 4-chlorobenzoate (59a) (154 mg, $0.90 \mathrm{mmol})$. Purification by column chromatography ( $n$-hexane/EtOAc: $7 / 3$ ) yielded 69ea $(71 \mathrm{mg}, 59 \%)$ and 69ea" (11 mg, 9\%) as colorless solids.

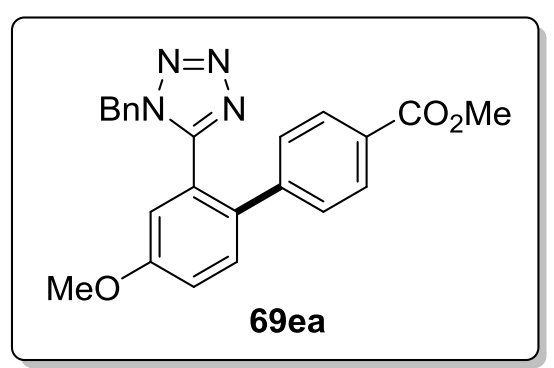

M. p.: $128-129^{\circ} \mathrm{C}$.

${ }^{\mathbf{1}} \mathbf{H}-\mathbf{N M R}\left(\mathrm{CDCl}_{3}, 300 \mathrm{MHz}\right): 7.89(\mathrm{~d}, J=8.4 \mathrm{~Hz}, 2 \mathrm{H}), 7.48(\mathrm{~d}, J=8.6 \mathrm{~Hz}, 1 \mathrm{H}), 7.20-7.08$ (m, 6H), $6.80(\mathrm{~d}, J=2.7 \mathrm{~Hz}, 1 \mathrm{H}), 6.75(\mathrm{~d}, J=8.4 \mathrm{~Hz}, 2 \mathrm{H}), 4.80(\mathrm{~s}, 2 \mathrm{H}), 3.88(\mathrm{~s}, 3 \mathrm{H}), 3.75$ (s, $3 \mathrm{H})$.

${ }^{13} \mathrm{C}-\mathrm{NMR}\left(\mathrm{CDCl}_{3}, 126 \mathrm{MHz}\right): \delta=166.5\left(\mathrm{C}_{\mathrm{q}}\right), 159.4\left(\mathrm{C}_{\mathrm{q}}\right), 154.2\left(\mathrm{C}_{\mathrm{q}}\right), 143.0\left(\mathrm{C}_{\mathrm{q}}\right), 132.9\left(\mathrm{C}_{\mathrm{q}}\right)$, $132.8\left(\mathrm{C}_{\mathrm{q}}\right), 131.5(\mathrm{CH}), 130.0(\mathrm{CH}), 129.1\left(\mathrm{C}_{\mathrm{q}}\right), 128.7(\mathrm{CH}), 128.6(\mathrm{CH}), 128.5(\mathrm{CH}), 127.7$ $(\mathrm{CH}), 123.7\left(\mathrm{C}_{\mathrm{q}}\right), 118.0(\mathrm{CH}), 115.7(\mathrm{CH}), 55.6\left(\mathrm{CH}_{3}\right), 52.2\left(\mathrm{CH}_{3}\right), 50.9\left(\mathrm{CH}_{2}\right)$.

IR (ATR): 2951, 1716, 1607, 1435, 1274, 1224, 1103, 1023, 826, $719 \mathrm{~cm}^{-1}$.

MS (EI) $m / z$ (relative intensity): 400 ([M+ $]$ 17), 399 (42), 371 (12), 91 (100), 65 (13).

HR-MS (ESI) $m / z$ for $\mathrm{C}_{23} \mathrm{H}_{21} \mathrm{~N}_{4} \mathrm{O}_{3}\left[\mathrm{M}+\mathrm{H}^{+}\right] \quad$ calcd.: 401.1608 .

found: 401.1610 . 


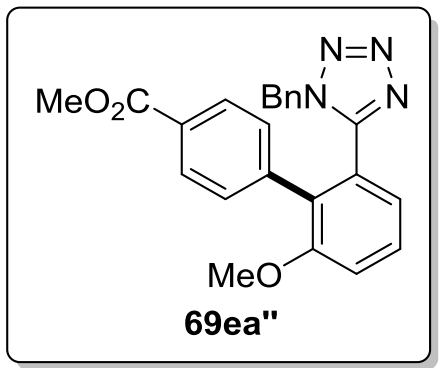

M. p.: $121-122^{\circ} \mathrm{C}$.

${ }^{1} \mathbf{H}-\mathbf{N M R}\left(\mathrm{CDCl}_{3}, 500 \mathrm{MHz}\right): 7.86(\mathrm{~d}, J=8.4 \mathrm{~Hz}, 2 \mathrm{H}), 7.43(\mathrm{dd}, J=8.4,7.7 \mathrm{~Hz}, 1 \mathrm{H}), 7.22$ (tt, $J=7.4,1.4 \mathrm{~Hz}, 1 \mathrm{H}), 7.20-7.15(\mathrm{~m}, 3 \mathrm{H}), 7.11(\mathrm{~d}, J=8.4 \mathrm{~Hz}, 2 \mathrm{H}), 6.93(\mathrm{dd}, J=7.7,1.0 \mathrm{~Hz}$, $1 \mathrm{H}), 6.83(\mathrm{dd}, J=8.4,1.4 \mathrm{~Hz}, 2 \mathrm{H}), 4.91(\mathrm{~s}, 2 \mathrm{H}), 3.88(\mathrm{~s}, 3 \mathrm{H}), 3.80$ (s, 3H).

${ }^{13}$ C-NMR $\left(\mathrm{CDCl}_{3}, 126 \mathrm{MHz}\right): \delta=166.6\left(\mathrm{C}_{\mathrm{q}}\right), 156.8\left(\mathrm{C}_{\mathrm{q}}\right), 153.8\left(\mathrm{C}_{\mathrm{q}}\right), 139.1\left(\mathrm{C}_{\mathrm{q}}\right), 133.1\left(\mathrm{C}_{\mathrm{q}}\right)$, $130.3(\mathrm{CH}), 130.0\left(\mathrm{C}_{\mathrm{q}}\right), 129.7(\mathrm{CH}), 129.3\left(\mathrm{C}_{\mathrm{q}}\right), 129.2(\mathrm{CH}), 128.8(\mathrm{CH}), 128.7(\mathrm{CH}), 127.8$ $(\mathrm{CH}), 124.8\left(\mathrm{C}_{\mathrm{q}}\right), 122.8(\mathrm{CH}), 113.8(\mathrm{CH}), 56.0\left(\mathrm{CH}_{3}\right), 52.2\left(\mathrm{CH}_{3}\right), 50.9\left(\mathrm{CH}_{2}\right)$.

IR (ATR): 2952, 1713, 1609, 1460, 1263, 1101, 1027, 801, 774, $754 \mathrm{~cm}^{-1}$

MS (EI) $m / z$ (relative intensity): 400 ([M+ $]$ 40), 399 (83), 371 (17), 91 (100), 65 (12).

HR-MS (ESI) $m / z$ for $\mathrm{C}_{23} \mathrm{H}_{21} \mathrm{~N}_{4} \mathrm{O}_{3}\left[\mathrm{M}+\mathrm{H}^{+}\right]$ calcd.: 401.1608 . found: 401.1600 . 
Synthesis of Methyl 2'-(1-benzyl-1H-tetrazol-5-yl)-5'-methoxy-[1,1'-biphenyl]-4carboxylate (69fa) and Dimethyl 2'-(1-benzyl-1H-tetrazol-5-yl)-5'-methoxy-[1,1':3',1'"terphenyl]-4,4"'-dicarboxylate (69fa')

The general procedure $\mathbf{F}$ was followed using $\mathbf{6 8 f}(79.9 \mathrm{mg}, 0.30 \mathrm{mmol})$ and methyl 4-chlorobenzoate (59a) (154 mg, $0.90 \mathrm{mmol})$. Purification by column chromatography $\left(\mathrm{CH}_{2} \mathrm{Cl}_{2}\right.$ /EtOAc: $\left.24 / 1\right)$ yielded 69fa (84 mg, 70\%) and 69fa' (19 mg, 12\%) as colorless solids.

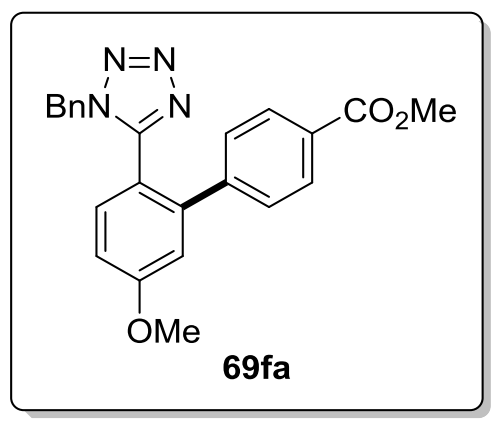

M. p.: $143-144{ }^{\circ} \mathrm{C}$.

${ }^{1} \mathbf{H}-\mathbf{N M R}\left(\mathrm{CDCl}_{3}, 300 \mathrm{MHz}\right): 7.88(\mathrm{~d}, J=8.4 \mathrm{~Hz}, 2 \mathrm{H}), 7.27(\mathrm{~d}, J=8.5 \mathrm{~Hz}, 1 \mathrm{H}), 7.18$ (tt, $J=7.4,1.4 \mathrm{~Hz}, 1 \mathrm{H}), 7.15-7.20(\mathrm{~m}, 4 \mathrm{H}), 7.04(\mathrm{~d}, J=2.6 \mathrm{~Hz}, 1 \mathrm{H}), 6.97$ (dd, $J=8.5,2.6 \mathrm{~Hz}$, $1 \mathrm{H}), 6.76(\mathrm{~d}, J=8.4 \mathrm{~Hz}, 2 \mathrm{H}), 4.81(\mathrm{~s}, 2 \mathrm{H}), 3.89(\mathrm{~s}, 3 \mathrm{H}), 3.88(\mathrm{~s}, 3 \mathrm{H})$.

${ }^{13} \mathrm{C}-\mathrm{NMR}\left(\mathrm{CDCl}_{3}, 126 \mathrm{MHz}\right): \delta=166.4\left(\mathrm{C}_{\mathrm{q}}\right), 161.8\left(\mathrm{C}_{\mathrm{q}}\right), 154.1\left(\mathrm{C}_{\mathrm{q}}\right), 143.2\left(\mathrm{C}_{\mathrm{q}}\right), 142.3\left(\mathrm{C}_{\mathrm{q}}\right)$, $133.0\left(\mathrm{C}_{\mathrm{q}}\right), 132.6(\mathrm{CH}), 130.0(\mathrm{CH}), 129.6\left(\mathrm{C}_{\mathrm{q}}\right), 128.7(\mathrm{CH}), 128.6(\mathrm{CH}), 128.5(\mathrm{CH}), 127.6$ $(\mathrm{CH}), 115.8(\mathrm{CH}), 114.5\left(\mathrm{C}_{\mathrm{q}}\right), 113.8(\mathrm{CH}), 55.6\left(\mathrm{CH}_{3}\right), 52.2\left(\mathrm{CH}_{3}\right), 50.7\left(\mathrm{CH}_{2}\right)$.

IR (ATR): 2947, 1720, 1607, 1436, 1288, 1213, 1107, 1012, 855, $725 \mathrm{~cm}^{-1}$.

MS (EI) $m / z$ (relative intensity): 400 ([ $\left.\mathrm{M}^{+}\right]$22), 399 (62), 371 (23), 91 (100), 65 (14).

HR-MS (ESI) $m / z$ for $\mathrm{C}_{23} \mathrm{H}_{21} \mathrm{~N}_{4} \mathrm{O}_{3}\left[\mathrm{M}+\mathrm{H}^{+}\right]$ calcd.: 401.1608 . found: 401.1610 . 


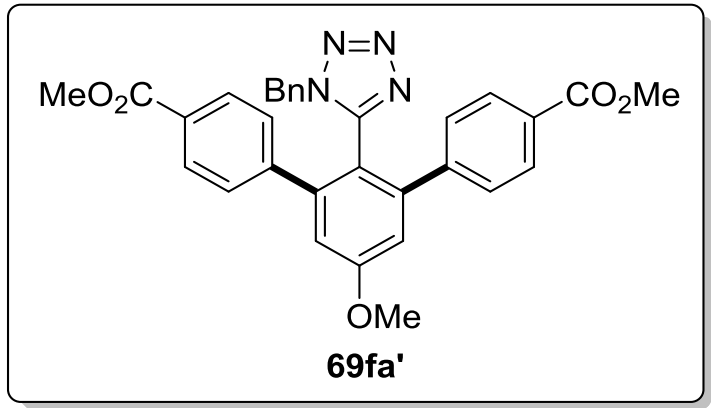

M. p.: $179-180{ }^{\circ} \mathrm{C}$.

${ }^{1} \mathbf{H}-\mathbf{N M R}\left(\mathrm{CDCl}_{3}, 300 \mathrm{MHz}\right): 7.81(\mathrm{~d}, J=8.6 \mathrm{~Hz}, 4 \mathrm{H}), 7.18-7.10(\mathrm{~m}, 3 \mathrm{H}), 7.02(\mathrm{~s}, 2 \mathrm{H})$, 7.00-6.97 (m, 4H), 6.70 (dd, $J=7.8,1.2 \mathrm{~Hz}, 2 \mathrm{H}), 4.67$ (s, 2H), 3.94 (s, 3H), 3.88 (s, 6H).

${ }^{13} \mathrm{C}-\mathrm{NMR}\left(\mathrm{CDCl}_{3}, 126 \mathrm{MHz}\right): \delta=166.3\left(\mathrm{C}_{\mathrm{q}}\right), 161.2\left(\mathrm{C}_{\mathrm{q}}\right), 152.3\left(\mathrm{C}_{\mathrm{q}}\right), 144.2\left(\mathrm{C}_{\mathrm{q}}\right), 143.1\left(\mathrm{C}_{\mathrm{q}}\right)$, $132.5\left(\mathrm{C}_{\mathrm{q}}\right), 129.5\left(\mathrm{C}_{\mathrm{q}}\right), 129.4(\mathrm{CH}), 128.8(\mathrm{CH}), 128.7(\mathrm{CH}), 128.5(\mathrm{CH}), 128.0(\mathrm{CH}), 115.4$ $(\mathrm{CH}), 113.3\left(\mathrm{C}_{\mathrm{q}}\right), 55.8\left(\mathrm{CH}_{3}\right), 52.2\left(\mathrm{CH}_{3}\right), 50.7\left(\mathrm{CH}_{2}\right)$.

IR (ATR): 2949, 1717, 1594, 1434, 1272, 1178, 1100, 1016, 854, $723 \mathrm{~cm}^{-1}$.

MS (EI) $m / z$ (relative intensity): 534 ([ $\left.\mathrm{M}^{+}\right]$51), 533 (73), 339 (13), 91 (100), 58 (55).

HR-MS (ESI) $m / z$ for $\mathrm{C}_{31} \mathrm{H}_{27} \mathrm{~N}_{4} \mathrm{O}_{5}\left[\mathrm{M}+\mathrm{H}^{+}\right]$

calcd.: 535.1976 .

found: 535.1975 . 
Synthesis of Methyl 4-\{3-(1-benzyl-1H-tetrazol-5-yl)naphthalen-2-yl\}benzoate (69ga)

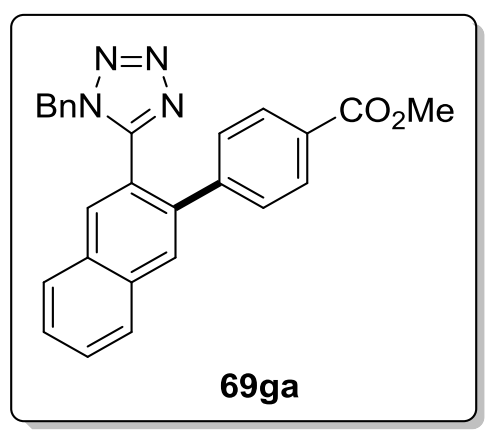

The general procedure $\mathbf{F}$ was followed using $\mathbf{6 8 g}(85.9 \mathrm{mg}, 0.30 \mathrm{mmol})$ and methyl 4-chlorobenzoate (59a) (154 mg, $0.90 \mathrm{mmol})$. Purification by column chromatography ( $n$-hexane/EtOAc: $7 / 3$ ) yielded 69ga (72 mg, 57\%) as a colorless solid.

M. p.: $162-163^{\circ} \mathrm{C}$.

${ }^{1} \mathbf{H}-\mathbf{N M R}\left(\mathrm{CDCl}_{3}, 500 \mathrm{MHz}\right): \delta=8.03(\mathrm{~s}, 1 \mathrm{H}), 7.96(\mathrm{dd}, J=8.3,1.2 \mathrm{~Hz}, 1 \mathrm{H}), 7.93(\mathrm{~d}$, $J=8.3 \mathrm{~Hz}, 2 \mathrm{H}), 7.91(\mathrm{~s}, 1 \mathrm{H}), 7.84(\mathrm{dd}, J=8.3,1.2 \mathrm{~Hz}, 1 \mathrm{H}), 7.65(\mathrm{ddd}, J=8.2,6.9,1.3 \mathrm{~Hz}$, $1 \mathrm{H}), 7.60$ (ddd, $J=8.2,6.9,1.3 \mathrm{~Hz}, 1 \mathrm{H}), 7.24$ (d, $J=8.3 \mathrm{~Hz}, 2 \mathrm{H}), 7.15$ (tt, $J=7.4,1.3 \mathrm{~Hz}$, 1H), $7.08(\mathrm{dd}, J=7.3,7.2 \mathrm{~Hz}, 2 \mathrm{H}), 6.75(\mathrm{dd}, J=8.1,1.3 \mathrm{~Hz}, 2 \mathrm{H}), 4.89$ (s, 2H), 3.91 (s, 3H).

${ }^{13}$ C-NMR $\left(\mathrm{CDCl}_{3}, 126 \mathrm{MHz}\right): \delta=166.5\left(\mathrm{C}_{\mathrm{q}}\right), 154.4\left(\mathrm{C}_{\mathrm{q}}\right), 143.4\left(\mathrm{C}_{\mathrm{q}}\right), 137.0\left(\mathrm{C}_{\mathrm{q}}\right), 134.2\left(\mathrm{C}_{\mathrm{q}}\right)$, $132.9\left(\mathrm{C}_{\mathrm{q}}\right), 132.1(\mathrm{CH}), 132.0\left(\mathrm{C}_{\mathrm{q}}\right), 130.1(\mathrm{CH}), 129.8(\mathrm{CH}), 129.5\left(\mathrm{C}_{\mathrm{q}}\right), 128.8(\mathrm{CH}), 128.7$ $(\mathrm{CH}), 128.6(\mathrm{CH}), 128.5(\mathrm{CH}), 128.2(\mathrm{CH}), 128.1(\mathrm{CH}), 127.7(\mathrm{CH}), 127.6(\mathrm{CH}), 120.5\left(\mathrm{C}_{\mathrm{q}}\right)$, $52.3\left(\mathrm{CH}_{3}\right), 51.0\left(\mathrm{CH}_{2}\right)$.

IR (ATR): 2951, 1708, 1606, 1430, 1277, 1100, 900, 777, 732, $477 \mathrm{~cm}^{-1}$.

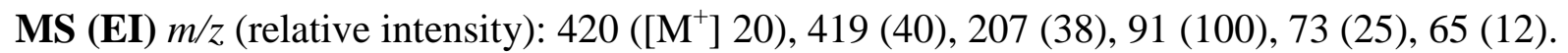

HR-MS (ESI) $m / z$ for $\mathrm{C}_{26} \mathrm{H}_{21} \mathrm{~N}_{4} \mathrm{O}_{2}\left[\mathrm{M}+\mathrm{H}^{+}\right] \quad$ calcd.: 421.1659 . found: 421.1655 . 
Synthesis of 1-\{2'-(1-Benzyl-1H-tetrazol-5-yl)-4'-methyl-[1,1'-biphenyl]-4-yl\}ethan-1-one (69cb)

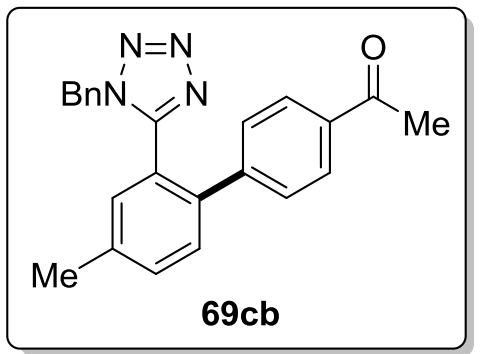

The general procedure $\mathbf{F}$ was followed using $\mathbf{6 8 c}(75.1 \mathrm{mg}, \quad 0.30 \mathrm{mmol})$ and 1-(4-chlorophenyl)ethan-1-one $\quad \mathbf{( 5 9 b )} \quad(139 \mathrm{mg}, \quad 0.90 \mathrm{mmol})$. Purification by column chromatography ( $n$-hexane/EtOAc: $4 / 1)$ yielded 69cb (92 mg, 83\%) as a colorless solid.

M. p.: $128-129^{\circ} \mathrm{C}$.

${ }^{1} \mathbf{H}-\mathbf{N M R}\left(\mathrm{CDCl}_{3}, 500 \mathrm{MHz}\right): \delta=7.79(\mathrm{~d}, J=8.5 \mathrm{~Hz}, 2 \mathrm{H}), 7.44(\mathrm{~s}, 1 \mathrm{H}), 7.44(\mathrm{~s}, 1 \mathrm{H}), 7.18(\mathrm{tt}$, $J=7.3,1.3 \mathrm{~Hz}, 1 \mathrm{H}), 7.16-7.10(\mathrm{~m}, 5 \mathrm{H}), 6.74(\mathrm{dd}, J=8.1,1.3 \mathrm{~Hz}, 2 \mathrm{H}), 4.83(\mathrm{~s}, 2 \mathrm{H}), 2.54(\mathrm{~s}$, $3 \mathrm{H}), 2.36(\mathrm{~s}, 3 \mathrm{H})$.

${ }^{13}$ C-NMR $\left(\mathrm{CDCl}_{3}, 126 \mathrm{MHz}\right): \delta=197.3\left(\mathrm{C}_{\mathrm{q}}\right), 154.3\left(\mathrm{C}_{\mathrm{q}}\right), 143.4\left(\mathrm{C}_{\mathrm{q}}\right), 138.7\left(\mathrm{C}_{\mathrm{q}}\right), 137.7\left(\mathrm{C}_{\mathrm{q}}\right)$, $136.0\left(\mathrm{C}_{\mathrm{q}}\right), 132.9\left(\mathrm{C}_{\mathrm{q}}\right), 132.4(\mathrm{CH}), 131.7(\mathrm{CH}), 130.1(\mathrm{CH}), 128.8(\mathrm{CH}), 128.7(\mathrm{CH}), 128.6$ $(\mathrm{CH}), 128.5(\mathrm{CH}), 127.7(\mathrm{CH}), 122.4\left(\mathrm{C}_{\mathrm{q}}\right), 50.9\left(\mathrm{CH}_{2}\right), 26.6\left(\mathrm{CH}_{3}\right), 20.9\left(\mathrm{CH}_{3}\right)$.

IR (ATR): 2921, 1679, 1605, 1403, 1357, 1265, 1101, 957, 821, $719 \mathrm{~cm}^{-1}$

MS (EI) $m / z$ (relative intensity): 368 ([M+] 35), 367 (87), 339 (22), 178 (17), 91 (100), 65 (12), 43 (19).

HR-MS (ESI) $m / z$ for $\mathrm{C}_{23} \mathrm{H}_{21} \mathrm{~N}_{4} \mathrm{O}\left[\mathrm{M}+\mathrm{H}^{+}\right] \quad$ calcd.: 369.1710 .

found: 369.1707 .

The analytical data are in accordance with those reported in the literature. ${ }^{[118]}$ 
Synthesis of 1-Benzyl-5-(4'-methoxy-4-methyl-[1,1'-biphenyl]-2-yl)-1H-tetrazole (69cc)

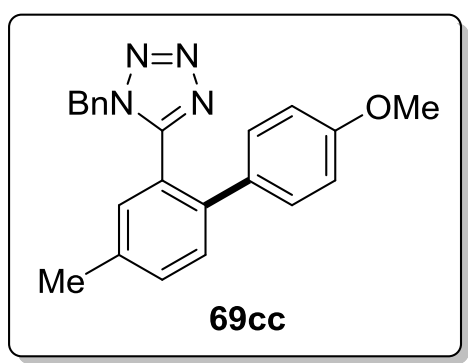

The general procedure $\mathbf{F}$ was followed using $\mathbf{6 8 c}(75.1 \mathrm{mg}, 0.30 \mathrm{mmol})$ and 1-chloro-4methoxybenzene $\mathbf{( 5 9 c )}(128 \mathrm{mg}, 0.90 \mathrm{mmol})$. Purification by column chromatography ( $n$-hexane/EtOAc: 4/1) yielded 69cc (90 mg, 84\%) as a colorless solid.

M. p.: $121-122^{\circ} \mathrm{C}$.

${ }^{1} \mathbf{H}-\mathbf{N M R}\left(\mathrm{CDCl}_{3}, 500 \mathrm{MHz}\right): \delta=7.40(\mathrm{~d}, J=7.9 \mathrm{~Hz}, 1 \mathrm{H}), 7.37(\mathrm{dd}, J=8.1,1.3 \mathrm{~Hz}, 1 \mathrm{H})$, $7.16(\mathrm{tt}, J=7.3,1.3 \mathrm{~Hz}, 1 \mathrm{H}), 7.12(\mathrm{~d}, J=7.6 \mathrm{~Hz}, 2 \mathrm{H}), 7.10(\mathrm{~s}, 1 \mathrm{H}), 7.02(\mathrm{~d}, J=8.7 \mathrm{~Hz}, 2 \mathrm{H})$, $6.77(\mathrm{~d}, J=8.7 \mathrm{~Hz}, 2 \mathrm{H}), 6.73(\mathrm{dd}, J=8.1,1.3 \mathrm{~Hz}, 2 \mathrm{H}), 4.74(\mathrm{~s}, 2 \mathrm{H}), 3.75(\mathrm{~s}, 3 \mathrm{H}), 2.32$ (s, $3 \mathrm{H})$.

${ }^{13} \mathbf{C}-\mathrm{NMR}\left(\mathrm{CDCl}_{3}, 126 \mathrm{MHz}\right): \delta=159.2\left(\mathrm{C}_{\mathrm{q}}\right), 154.9\left(\mathrm{C}_{\mathrm{q}}\right), 138.3\left(\mathrm{C}_{\mathrm{q}}\right), 137.3\left(\mathrm{C}_{\mathrm{q}}\right), 133.1\left(\mathrm{C}_{\mathrm{q}}\right)$, $132.2(\mathrm{CH}), 131.6(\mathrm{CH}), 131.0\left(\mathrm{C}_{\mathrm{q}}\right), 129.9(\mathrm{CH}), 129.6(\mathrm{CH}), 128.5(\mathrm{CH}), 128.3(\mathrm{CH}), 127.8$ $(\mathrm{CH}), 122.1\left(\mathrm{C}_{\mathrm{q}}\right), 114.3(\mathrm{CH}), 55.2\left(\mathrm{CH}_{3}\right), 50.7\left(\mathrm{CH}_{2}\right), 20.7\left(\mathrm{CH}_{3}\right)$.

IR (ATR): 2941, 1610, 1484, 1450, 1249, 1180, 1099, 1033, 852, $721 \mathrm{~cm}^{-1}$.

MS (EI) $m / z$ (relative intensity): 356 ([M+] 37), 355 (71), 327 (28), 165 (16), 91 (100), 65 (12).

HR-MS (ESI) $m / z$ for $\mathrm{C}_{22} \mathrm{H}_{21} \mathrm{~N}_{4} \mathrm{O}\left[\mathrm{M}+\mathrm{H}^{+}\right] \quad$ calcd.: 357.1710 . found: 357.1707 . 
Synthesis of 1-Benzyl-5-\{4-methyl-4'-(methylthio)-[1,1'-biphenyl]-2-yl\}-1H-tetrazole (69cd)

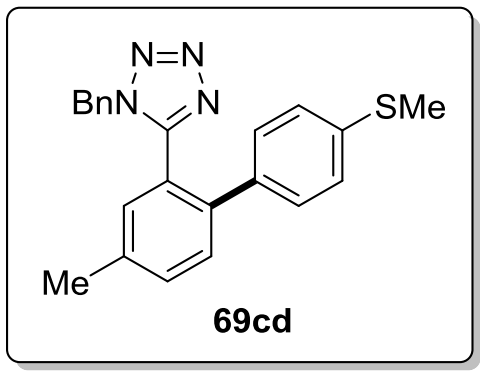

The general procedure $\mathbf{F}$ was followed using $\mathbf{6 8 c}(75.1 \mathrm{mg}, \quad 0.30 \mathrm{mmol})$ and (4-chlorophenyl)(methyl)sulfane $\quad$ (59d) $\quad(143 \mathrm{mg}, \quad 0.90 \mathrm{mmol})$. Purification by column chromatography $\left(\mathrm{CH}_{2} \mathrm{Cl}_{2} /\right.$ EtOAc: $\left.24 / 1\right)$ yielded $69 \mathrm{~cd}(71 \mathrm{mg}, 64 \%)$ as a pale yellow solid.

M. p.: $116-117^{\circ} \mathrm{C}$.

${ }^{1}$ H-NMR $\left(\mathrm{CDCl}_{3}, 400 \mathrm{MHz}\right): \delta=7.41(\mathrm{~d}, J=0.7 \mathrm{~Hz}, 1 \mathrm{H}), 7.40(\mathrm{dd}, J=1.7,0.6 \mathrm{~Hz}, 1 \mathrm{H})$, 7.18 (tt, $J=7.3,1.3 \mathrm{~Hz}, 1 \mathrm{H}), 7.14(\mathrm{dd}, J=7.4,5.6 \mathrm{~Hz}, 2 \mathrm{H}), 7.13-7.11(\mathrm{~m}, 1 \mathrm{H}), 7.10(\mathrm{~d}$, $J=8.7 \mathrm{~Hz}, 2 \mathrm{H}), 7.01(\mathrm{~d}, J=8.7 \mathrm{~Hz}, 2 \mathrm{H}), 6.73(\mathrm{dd}, J=8.1,1.3 \mathrm{~Hz}, 2 \mathrm{H}), 4.78(\mathrm{~s}, 2 \mathrm{H}), 2.44(\mathrm{~s}$, $3 \mathrm{H}), 2.34(\mathrm{~s}, 3 \mathrm{H})$.

${ }^{13}$ C-NMR $\left(\mathrm{CDCl}_{3}, 126 \mathrm{MHz}\right): \delta=154.7\left(\mathrm{C}_{\mathrm{q}}\right), 138.8\left(\mathrm{C}_{\mathrm{q}}\right), 138.1\left(\mathrm{C}_{\mathrm{q}}\right), 137.8\left(\mathrm{C}_{\mathrm{q}}\right), 135.1\left(\mathrm{C}_{\mathrm{q}}\right)$, $133.0\left(\mathrm{C}_{\mathrm{q}}\right), 132.3(\mathrm{CH}), 131.7(\mathrm{CH}), 129.9(\mathrm{CH}), 128.8(\mathrm{CH}), 128.6(\mathrm{CH}), 128.4(\mathrm{CH}), 127.8$ $(\mathrm{CH}), 126.3(\mathrm{CH}), 122.2\left(\mathrm{C}_{\mathrm{q}}\right), 50.8\left(\mathrm{CH}_{2}\right), 20.8\left(\mathrm{CH}_{3}\right), 15.2\left(\mathrm{CH}_{3}\right)$.

IR (ATR): 2921, 1477, 1439, 1241, 1092, 812, 722, 694, 548, $527 \mathrm{~cm}^{-1}$.

MS (EI) $\mathrm{m} / z$ (relative intensity): 372 ([M+] 61), 371 (42), 343 (20), 206 (14), 91 (100), 65 (11), 43 (11).

HR-MS (EI) $m / z$ for $\mathrm{C}_{22} \mathrm{H}_{20} \mathrm{~N}_{4} \mathrm{~S}\left[\mathrm{M}^{+}\right]$

calcd.: 372.1409 .

found: 372.1414 . 


\section{Synthesis of 1-Benzyl-5-\{5-methyl-2-(thiophen-3-yl)phenyl\}-1H-tetrazole (69ce)}

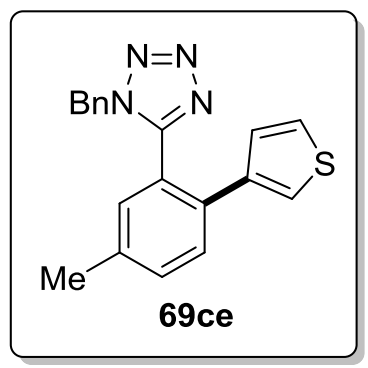

The general procedure $\mathbf{F}$ was followed using $\mathbf{6 8 c} \quad(75.1 \mathrm{mg}, \quad 0.30 \mathrm{mmol})$ and 3-chlorothiophene (59e) (107 mg, $0.90 \mathrm{mmol})$. Purification by column chromatography ( $n$-hexane/EtOAc: 6/1) yielded 69ce $(67 \mathrm{mg}, 67 \%)$ as a pale yellow solid.

M. p.: $96-97^{\circ} \mathrm{C}$.

${ }^{1} \mathbf{H}-\mathbf{N M R}\left(\mathrm{CDCl}_{3}, 500 \mathrm{MHz}\right): \delta=7.48(\mathrm{~d}, J=7.9 \mathrm{~Hz}, 1 \mathrm{H}), 7.37(\mathrm{dq}, J=7.9,0.8 \mathrm{~Hz}, 1 \mathrm{H})$, $7.24(\mathrm{q}, J=3.0 \mathrm{~Hz}, 1 \mathrm{H}), 7.18(\mathrm{tt}, J=7.3,1.3 \mathrm{~Hz}, 1 \mathrm{H}), 7.16-7.12(\mathrm{~m}, 2 \mathrm{H}), 7.09-7.07(\mathrm{~m}, 1 \mathrm{H})$, $6.95(\mathrm{dd}, J=3.0,1.4 \mathrm{~Hz}, 1 \mathrm{H}), 6.79-6.75(\mathrm{~m}, 3 \mathrm{H}), 4.81(\mathrm{~s}, 2 \mathrm{H}), 2.33(\mathrm{~s}, 3 \mathrm{H})$.

${ }^{13}$ C-NMR $\left(\mathrm{CDCl}_{3}, 126 \mathrm{MHz}\right): \delta=154.7\left(\mathrm{C}_{\mathrm{q}}\right), 139.4\left(\mathrm{C}_{\mathrm{q}}\right), 137.8\left(\mathrm{C}_{\mathrm{q}}\right), 133.5\left(\mathrm{C}_{\mathrm{q}}\right), 133.0\left(\mathrm{C}_{\mathrm{q}}\right)$, $132.3(\mathrm{CH}), 131.6(\mathrm{CH}), 129.6(\mathrm{CH}), 128.6(\mathrm{CH}), 128.5(\mathrm{CH}), 127.9(\mathrm{CH}), 127.4(\mathrm{CH}), 126.7$ $(\mathrm{CH}), 123.2(\mathrm{CH}), 122.1\left(\mathrm{C}_{\mathrm{q}}\right), 50.8\left(\mathrm{CH}_{2}\right), 20.8\left(\mathrm{CH}_{3}\right)$.

IR (ATR): 2954, 1482, 1409, 1243, 1103, 853, 802, 728, 695, $647 \mathrm{~cm}^{-1}$.

MS (EI) $\mathrm{m} / z$ (relative intensity): 332 ([M+] 26), 213 (24), 198 (20), 185 (42), 91 (100), 65 (25), 43 (18).

HR-MS (EI) $m / z$ for $\mathrm{C}_{19} \mathrm{H}_{16} \mathrm{~N}_{4} \mathrm{~S}\left[\mathrm{M}^{+}\right]$

calcd.: 332.1096.

found: 332.1097 . 
Synthesis of Methyl $N$-\{[2'-(1-benzyl-1H-tetrazol-5-yl)-[1,1'-biphenyl]-4-yl]methyl\}-

$N$-pentanoyl-L-valinate (69at)

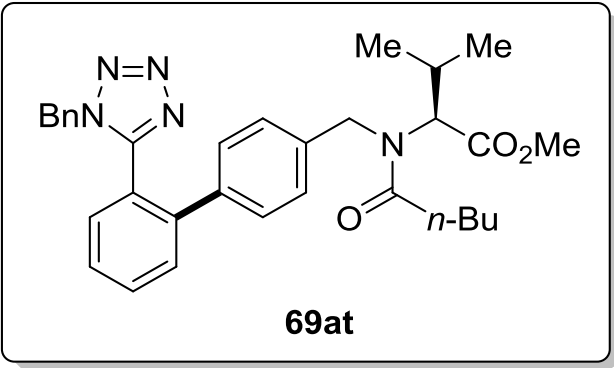

The general procedure $\mathbf{F}$ was followed using $\mathbf{6 8 a}(70.9 \mathrm{mg}, 0.30 \mathrm{mmol})$ and aryl chloride 59t (306 mg, $0.90 \mathrm{mmol}$ ). Purification by column chromatography ( -hexane/EtOAc: 4/1) yielded 69at (117 $\mathrm{mg}, 72 \%)$ as a colorless solid.

Alternatively the general procedure $\mathbf{F}$ was followed with $\mathbf{6 8 a}(70.9 \mathrm{mg}, 0.30 \mathrm{mmol})$ and aryl bromide $\mathbf{5 2 t} \quad(127 \mathrm{mg}, \quad 0.33 \mathrm{mmol})$. Purification by column chromatography ( $n$-hexane/EtOAc: 4/1) yielded 60at (144 mg, 89\%) as a colorless solid.

M. p.: $74-75{ }^{\circ} \mathrm{C}$.

${ }^{1} \mathbf{H}$-NMR (DMSO-d $\left.6,120{ }^{\circ} \mathrm{C}, 300 \mathrm{MHz}\right): \delta=7.70(\mathrm{ddd}, J=7.8,7.6,1.5 \mathrm{~Hz}, 1 \mathrm{H}), 7.58(\mathrm{dd}$, $J=7.8,1.3 \mathrm{~Hz}, 1 \mathrm{H}), 7.52(\mathrm{dd}, J=7.4,1.3 \mathrm{~Hz}, 1 \mathrm{H}), 7.45(\mathrm{dd}, J=7.6,1.3 \mathrm{~Hz}, 1 \mathrm{H}), 7.31-7.18$ $(\mathrm{m}, 3 \mathrm{H}), 7.11(\mathrm{~d}, J=8.2 \mathrm{~Hz}, 2 \mathrm{H}), 7.01(\mathrm{~d}, J=8.2 \mathrm{~Hz}, 2 \mathrm{H}), 6.93-6.85(\mathrm{~m}, 2 \mathrm{H}), 5.08(\mathrm{~s}, 2 \mathrm{H})$, $4.69(\mathrm{~d}, J=16.9 \mathrm{~Hz}, 1 \mathrm{H}), 4.50(\mathrm{~d}, J=16.9 \mathrm{~Hz}, 1 \mathrm{H}), 4.47-4.38(\mathrm{~m}, 1 \mathrm{H}), 3.40(\mathrm{~s}, 3 \mathrm{H})$, 2.45-2.20 (m, 3H), 1.63-1.48 (m, 2H), 1.38-1.23 (m, 2H), $0.96(\mathrm{~d}, J=6.5 \mathrm{~Hz}, 3 \mathrm{H})$, $0.90-0.80(\mathrm{~m}, 6 \mathrm{H})$.

${ }^{13}$ C-NMR (DMSO-d $\left.6,120{ }^{\circ} \mathrm{C}, 75 \mathrm{MHz}\right): \delta=172.8\left(\mathrm{C}_{\mathrm{q}}\right), 169.7\left(\mathrm{C}_{\mathrm{q}}\right), 153.5\left(\mathrm{C}_{\mathrm{q}}\right), 140.9\left(\mathrm{C}_{\mathrm{q}}\right)$, $137.3\left(\mathrm{C}_{\mathrm{q}}\right), 136.7\left(\mathrm{C}_{\mathrm{q}}\right), 133.0\left(\mathrm{C}_{\mathrm{q}}\right), 130.7(\mathrm{CH}), 130.1(\mathrm{CH}), 129.6(\mathrm{CH}), 127.9(\mathrm{CH}), 127.7$ $(\mathrm{CH}), 127.6(\mathrm{CH}), 127.1(\mathrm{CH}), 127.0(\mathrm{CH}), 126.1(\mathrm{CH}), 122.0\left(\mathrm{C}_{\mathrm{q}}\right), 50.5\left(\mathrm{CH}_{3}\right), 49.9\left(\mathrm{CH}_{2}\right)$, $47.0\left(\mathrm{CH}_{2}\right), 31.8\left(\mathrm{CH}_{2}\right), 26.9(\mathrm{CH}), 26.3\left(\mathrm{CH}_{2}\right), 21.0\left(\mathrm{CH}_{2}\right), 18.9\left(\mathrm{CH}_{3}\right), 17.9\left(\mathrm{CH}_{3}\right), 12.8$ $(\mathrm{CH})$.

IR (ATR): 2958, 1736, 1648, 1468, 1405, 1202, 1057, 1007, 820, $720 \mathrm{~cm}^{-1}$. 
MS (EI) $\mathrm{m} / z$ (relative intensity): 539 ([M+] 5), 454 (83), 396 (22), 340 (69), 325 (38), 192 (25), 91 (100), 57 (29).

HR-MS (EI) $m / z$ for $\mathrm{C}_{32} \mathrm{H}_{37} \mathrm{~N}_{5} \mathrm{O}_{3}\left[\mathrm{M}^{+}\right]$

calcd.: 539.2896 .

found: 539.2894 .

The analytical data are in accordance with those reported in the literature. ${ }^{[131]}$ 


\section{References}

[1] A. Kreimeyer, P. Eckes, C. Fischer, H. Lauke, P. Schuhmacher, Angew. Chem. Int. Ed. 2015, 54, 3178-3195.

[2] Q. Michaudel, Y. Ishihara, P. S. Baran, Acc. Chem. Res. 2015, 48, 712-721.

[3] G. M. Whitesides, Angew. Chem. Int. Ed. 2015, 54, 3196-3209.

[4] B. Sam, B. Breit, M. J. Krische, Angew. Chem. Int. Ed. 2015, 54, 3267-3274.

[5] L. Ackermann, Modern Arylation Methods, Wiley-VCH, Weinheim, 2009.

[6] J.-Q. Yu, Z. Shi, eds. C-H activation, 292, Springer, Heidelberg, 2010.

[7] L. Ackermann, Chem. Rev. 2011, 111, 1315-1345.

[8] L. Ackermann, R. Vicente, A. R. Kapdi, Angew. Chem. Int. Ed. 2009, 48, 9792-9826.

[9] J. Yamaguchi, A. D. Yamaguchi, K. Itami, Angew. Chem. Int. Ed. 2012, 51, 8960-9009.

[10] P. B. Arockiam, C. Bruneau, P. H. Dixneuf, Chem. Rev. 2012, 112, 5879-5918.

[11] T. W. Lyons, M. S. Sanford, Chem. Rev. 2010, 110, 1147-1169.

[12] O. Daugulis, H.-Q. Do, D. Shabashov, Acc. Chem. Res. 2009, 42, 1074-1086.

[13] D. Alberico, M. E. Scott, M. Lautens, Chem. Rev. 2007, 107, 174-238.

[14] (a) F. Diederich, P. J. Stang, Metal-catalyzed cross-coupling rections, Wiley-VCH, New York, 2004; (b) K. C. Nicolaou, P. G. Bulger, D. Sarlah, Angew. Chem. Int. Ed. 2005, 44, 4442-4489.

[15] L. Ackermann, Org. Process Res. Dev. 2015, 19, 260-269.

[16] L. Ackermann, J. Org. Chem. 2014, 79, 8948-8954.

[17] M. Seki, Org. Process Res. Dev. 2016, 20, 867-877.

[18] G. Bringmann, T. Gulder, T. A. M. Gulder, M. Breuning, Chem. Rev. 2011, 111, 563639.

[19] G. Bringmann, D. Menche, Acc. Chem. Res. 2001, 34, 615-624.

[20] F. Ullmann, J. Bielecki, Chem. Ber. 1901, 34, 2174-2185.

[21] J. Hassan, M. Svignon, C. Gozzi, E. Schulz, M. Lemaire, Chem. Rev. 2002, 102, 1359-1469.

[22] P. Kovacic, M. B. Jones, Chem. Rev. 1987, 87, 357-379.

[23] M. Gomberg, W. E. Bachmann, J. Am. Chem. Soc. 1924, 46, 2339-2343.

[24] http://www.nobelprize.org/nobel_prizes/chemistry/laureates/2010 (accessed July 26th, 2016).

[25] R. K. Chinnagolla, M. Jeganmohan, Org. Lett. 2012, 14, 5246-5249. 
[26] H. Li, W. Wie, Y. Xu, C. Zhang, X. Wan, Chem. Commun. 2011, 47, 1497-1499.

[27] S. Yang, B. Li, X. Wan, Z. Shi, J. Am. Chem. Soc. 2007, 129, 6066-6067.

[28] Z. Shi, B. Li, X. Wan, J. Cheng, Z. Fang, B. Cao, C. Qin, Y. Wang, Angew. Chem. Int. Ed. 2007, 46, 5554-5558.

[29] B.-J. Li, S.-L. Tian, Z. Fang, Z.-J. Shi, Angew. Chem. Int. Ed. 2008, 47, 1115-1118.

[30] G. Brasche, J. García-Fortanet, S. L. Buchwald, Org. Lett. 2008, 10, 2207-2210.

[31] C. S. Yeung, X. Zhao, N. Borduas, V. M. Dong, Chem. Sci. 2010, 1, 331-336.

[32] J. Wencel-Delord, C. Nimphius, H. Wang, F. Glorius, Angew. Chem. Int. Ed. 2012, $51,13001-13005$.

[33] F. Yang, F. Song, W. Li, J. Lan, J. You, RSC Adv. 2013, 3, 9649-9652.

[34] (a) M. Simonetti, G. J. P. Perry, X. C. Cambeiro, F. Juliá-Hernández, J. N. Arokianathar, I. Larrosa, J. Am. Chem. Soc. 2016, 138, 3596-3606; (b) B. Zhao, Synth. Commun. 2013, 43, 2110-2118; (c) J. Zhang, Q. Yang, Z. Zhu, M. L. Yuan, H. Y. Fu, X. L. Zheng, H. Chen, R. X. Li, Eur. J. Org. Chem. 2012, 6702-6706; (d) L. Ackermann, A. V. Lygin, Org. Lett. 2011, 13, 3332-3335; (e) S. G. Ouellet, A. Roy, C. Molinaro, R. Angelaud, J.-F. Marcoux, P. D. O’Shea, I. W. Davies, J. Org. Chem. 2011, 76, 1436-1439; (f) E. F. Flegeau, C. Bruneau, P. H. Dixneuf, A. Jutand, J. Am. Chem. Soc. 2011, 133, 10161-10170; (g) B. Štefane, J. Fabris, F. Požgan, Eur. J. Org. Chem. 2011, 3474-3481; (h) P. B. Arockiam, C. Fischmeister, C. Bruneau, P. H. Dixneuf, Angew. Chem. Int. Ed. 2010, 49, 6629-6632; (i) N. Luo, Z. Yu, Chem. Eur. J. 2010, 16, 787-791; (j) H. Miura, K. Wada, S. Hosokawa, M. Inoue, Chem. Eur. J. 2010, 16, 4186-4189; (k) A. Prades, M. Poyatos, E. Perisa, Adv. Synth. Catal. 2010, 352, 1155-1162; (1) P. Arockiam, V. Poirier, C. Fischmeister, C. Bruneau, P. H. Dixneuf, Green Chem. 2009, 11, 1871-1875; (m) K. Cheng, Y. Zhang, J. Zhao, C. Xie, Synlett 2008, 1325-1330; (n) K. Godula, B. Sezen, D. Sames, J. Am. Chem. Soc. 2005, 127, 3648-3649.

[35] D. Balcells, E. Clot, O. Eisenstein, Chem. Rev. 2010, 110, 749-823.

[36] Y. Boutadla, D. L. Davies, S. A. Macgregor, A. I. Poblador-Bahamonde, Dalton Trans. 2009, 5820-5831.

[37] S. R. Neufeldt, M. S. Sanford, Acc. Chem. Res. 2012, 45, 936-946.

[38] K. Shen, Y. Fu, J.-N. Li, L. Liu, Q.-X. Guo, Tetrahedron 2007, 63, 1568-1576.

[39] G. Rousseau, B. Breit, Angew. Chem. Int. Ed. 2011, 50, 2450-2494.

[40] L. Ackermann, E. Diers, A. Manvar, Org. Lett. 2012, 14, 1154-1157.

[41] N. Uhlig, C.-J. Li, Chem. Eur. J. 2014, 20, 12066-12070. 
[42] J. P. Kleinman, M. Dubeck, J. Am. Chem. Soc. 1963, 85, 1544-1545.

[43] F. Kakiuchi, N. Chatani, Adv. Synth. Catal. 2003, 345, 1077-1101.

[44] A. C. Cope, E. C. Friedrich, J. Am. Chem. Soc. 1968, 90, 909-913.

[45] A. C. Cope, R. W. Siekman, J. Am. Chem. Soc. 1965, 87, 3272-3273.

[46] M. I. Bruce, Angew. Chem. Int. Ed. 1977, 16, 73-86.

[47] M. I. Bruce, M. Z. Iqbal, F. G. A. Stone, J. Chem. Soc. A 1971, 2820-2828.

[48] M. I. Bruce, M. Z. Iqbal, F. G. A. Stone, J. Chem. Soc. A 1970, 3204-3209.

[49] J. Chatt, J. M. Davidson, J. Chem. Soc. 1965, 843-855.

[50] J. Chatt, H. R. Watson, J. Chem. Soc. 1962, 2545-2549.

[51] H. C. L. Abbenhuis, M. Pfeffer, J. P. Sutter, A. de Cian, J. Fischer, H. L. Ji, J. H. Nelson, Organometallics 1993, 12, 4464-4472.

[52] S. Fernández, M. Pfeffer, V. Ritleng, C. Sirlin, Organometallics 1999, 18, 2390-2394.

[53] W. H. Knoth, R. A. Schumn, J. Am. Chem. Soc. 1969, 91, 2400-2400.

[54] G. W. Parshall, W. H. Knoth, R. A. Schunn, J. Am. Chem. Soc. 1969, 91, 4990-4995.

[55] J. J. Levison, S. D. Robinson, J. Chem. Soc. A 1970, 639-643.

[56] E. W. Ainscough, S. D. Robinson, J. J. Levison, J. Chem. Soc. A 1971, 3413-3424.

[57] D. L. Davies, O. Al-Duaij, J. Fawcett, M. Giardello, S. T. Hilton, D. R. Russell, Dalton Trans. 2003, 4132-4138.

[58] S. J. Tremont, H. U. Rahman, J. Am. Chem. Soc. 1984, 106, 5759-5760.

[59] J. S. McCallum, J. R. Gasdaska, L. S. Liebeskind, S. J. Tremont, Tetrahedron Lett. 1989, 30, 4085-4088.

[60] O. Daugulis, V. G. Zaitsev, Angew. Chem. Int. Ed. 2005, 44, 4046-4048.

[61] D. Shabashov, O. Daugulis, J. Org. Chem. 2007, 72, 7720-7725.

[62] D. Kalyani, N. R. Deprez, L. V. Desai, M. S. Sanford, J. Am. Chem. Soc. 2005, 127, $7330-7331$.

[63] T. Nishikata, A. R. Abela, S. Huang, B. H. Lipshutz, J. Am. Chem. Soc. 2010, 132, 4978-4979.

[64] T. Nishikata, A. R. Abela, B. H. Lipshutz, Angew. Chem. Int. Ed. 2010, 49, 781-784.

[65] D. Li, N. Xu, Y. Zhang, L. Wang, Chem. Commun. 2014, 50, 14862-14865.

[66] R. Haridharan, K. Muralirajan, C.-H. Cheng, Adv. Synth. Catal. 2015, 357, 366-370.

[67] M. K. Lakshman, A. C. Deb, R. R. Chamala, P. Pradhan, R. Pratap, Angew. Chem. Int. Ed. 2011, 50, 11400-11404.

[68] H.-M. Guo, L.-L. Jiang, H.-Y. Niu, W.-H. Rao, L. Liang, R.-Z. Mao, D.-Y. Li, G.-R. Qu, Org. Lett. 2011, 13, 2008-2011. 
[69] L. N. Lewis, J. F. Smith, J. Am. Chem. Soc. 1986, 108, 2728-2735.

[70] S. Murai, F. Kakiuchi, S. Sekine, Y. Tanaka, A. Kamatani, M. Sonoda, N. Chatani, Nature 1993, 366, 529-531.

[71] F. Kakiuchi, Y. Yamamoto, N. Chatani, S. Murai, Chem. Lett. 1995, 681-682.

[72] F. Kakiuchi, S. Murai, Acc. Chem. Res. 2002, 35, 826-834.

[73] F. Kakiuchi, M. Matsumoto, M. Sonoda, T. Fukuyama, N. Chatani, S. Murai, N. Furukawa, Y. Seki, Chem. Lett. 2000, 750-751.

[74] F. Kakiuchi, K. Igi, M. Matsumoto, N. Chatani, S. Murai, Chem. Lett. 2001, 422-423.

[75] F. Kakiuchi, Y. Matsuura, S. Kan, N. Chatani, J. Am. Chem. Soc. 2005, 127, 5936-5945.

[76] F. Kakiuchi, S. Kan, K. Igi, N. Chatani, S. Murai, J. Am. Chem. Soc. 2003, 125, $1698-1699$.

[77] P. Nareddy, F. Jordan, S. E. Brenner-Moyer, M. Szostak, ACS Catal. 2016, 6, 4755-4759.

[78] D. J. Paymode, C. V. Ramana, J. Org. Chem. 2015, 80, 11551-11558.

[79] S. Miyamura, H. Tsurugi, T. Satoh, M. Miura, J. Organomet. Chem. 2008, 693, $2438-2442$.

[80] C. Qian, D. Lin, Y. Deng, X.-Q. Zhang, H. Jiang, G. Miao, X. Tang, W. Zeng, Org. Biomol. Chem. 2014, 12, 5866-5875.

[81] S. Sharma, S. H. Han, S. Han, W. Ji, J. Oh, S.-Y. Lee, J. S. Oh, Y. H. Jung, I. S. Kim, Org. Lett. 2015, 17, 2852-2855.

[82] D. Zhang, X. Cui, Q. Zhang, Y. Wu, J. Org. Chem. 2015, 80, 1517-1522.

[83] G. Hong, D. Mao, S. Wu, L. Wang, J. Org. Chem. 2014, 79, 10629-10635.

[84] B. Majhi, D. Kundu, S. Ahammed, B. C. Ranu, Chem. Eur. J. 2014, 20, 9862-9866.

[85] T. Ryu, J. Min, W. Choi, W. H. Jeon, P. H. Lee, Org. Lett. 2014, 16, 2810-2813.

[86] H. Song, D. Chen, C. Pi, X. Cui, Y. Wu, J. Org. Chem. 2014, 79, 2955-2962.

[87] H. Wang, Y. Yu, X. Hong, Q. Tan, B. Xu, J. Org. Chem. 2014, 79, 3279-3288.

[88] H. Tang, C. Qian, D. Lin, H. Jiang, W. Zeng, Adv. Synth. Catal. 2014, 356, 519-527.

[89] J. Han, C. Pan, X. Jia, C. Zhu, Org. Biomol. Chem. 2014, 12, 8603-8606.

[90] X. Jia, J. Han, J. Org. Chem. 2014, 79, 4180-4185.

[91] K. Muralirajan, C.-H. Cheng, Chem. Eur. J. 2013, 19, 6198-6202.

[92] H. Li, P. Li, L. Wang, Org. Lett. 2013, 15, 620-623.

[93] Y. Lian, R. G. Bergman, L. D. Lavis, J. A. Ellman, J. Am. Chem. Soc. 2013, 135, $7122-7125$. 
[94] F. Xiong, C. Qian, D. Lin, W. Zeng, X. Lu, Org. Lett. 2013, 15, 5444-5447.

[95] Z.-Y. Li, D.-D. Li, G.-W. Wang, J. Org. Chem. 2013, 78, 10414-10420.

[96] H. Li, P. Li, H. Tan, L. Wang, Chem. Eur. J. 2013, 19, 14432-14436.

[97] Z. Yin, X. Jiang, P. Sun, J. Org. Chem. 2013, 78, 10002-10007.

[98] X.-T. Ma, S.-K. Tian, Adv. Synth. Catal. 2013, 355, 337-340.

[99] S. Oi, S. Fukita, N. Hirata, N. Watanuki, S. Miyano, Y. Inoue, Org. Lett. 2001, 3, 2579-2581.

[100] S. Oi, Y. Ogino, S. Fukita, Y. Inoue, Org. Lett. 2002, 4, 1783-1785.

[101] S. Oi, E. Aizawa, Y. Ogino, Y. Inoue, J. Org. Chem. 2005, 70, 3113-3119.

[102] L. Ackermann, A. Althammer, R. Born, Synlett 2007, 2833-2836.

[103] L. Ackermann, Org. Lett. 2005, 7, 3123-3125.

[104] L. Ackermann, A. Althammer, R. Born, Angew. Chem. Int. Ed. 2006, 45, 2619-2622.

[105] S. I. Kozhushkov, H. K. Potukuchi, L. Ackermann, Catal. Sci. Technol. 2013, 3, $562-571$.

[106] L. Ackermann, J. Pospech, H. K. Potukuchi, Org. Lett. 2012, 14, 2146-2149.

[107] L. Ackermann, M. Mulzer, Org. Lett. 2008, 10, 5043-5045.

[108] L. Ackermann, P. Novák, R. Vicente, V. Pirovano, H. K. Potukuchi, Synthesis 2010, $2245-2253$.

[109] L. Ackermann, R. Born, R. Vicente, ChemSusChem 2009, 2, 546-549.

[110] L. Ackermann, R. Vicente, A. Althammer, Org. Lett. 2008, 10, 2299-2302.

[111] D. L. Davies, S. M. A. Donald, S. A. Macgregor, J. Am. Chem. Soc. 2005, 127, $13754-13755$.

[112] H.-Y. Sun, S. I. Gorelsky, D. R. Stuart, L.-C. Campeau, K. Fagnou, J. Org. Chem. 2010, 75, 8180-8189.

[113] S. I. Gorelsky, D. Lapointe, K. Fagnou, J. Am. Chem. Soc. 2008, 130, 10848-10849.

[114] D. García-Cuadrado, P. de Mendoza, A. A. C. Braga, F. Maseras, A. M. Echavarren, J. Am. Chem. Soc. 2007, 129, 6880-6886.

[115] M. Lafrance, S. I. Gorelsky, K. Fagnou, J. Am. Chem. Soc. 2007, 129, 14570-14571.

[116] D. García-Cuadrado, A. A. C. Braga, F. Maseras, A. M. Echavarren, J. Am. Chem. Soc. 2006, 128, 1066-1067.

[117] L. Ackermann, Acc. Chem. Res. 2014, 47, 281-295.

[118] E. Diers, N. Y. P. Kumar, T. Mejuch, I. Marek, L. Ackermann, Tetrahedron 2013, 69 4445-4453.

[119] M. Seki, RSC Adv. 2014, 4, 29131-29133. 
[120] M. Seki, Synthesis 2012, 3231-3237.

[121] M. Seki, ACS Catal. 2011, 1, 607-610.

[122] M. Seki, M. Nagahama, J. Org. Chem. 2011, 76, 10198-10206.

[123] S. Ghosh, A. S. Kumar, G. N. Mehta, Beilstein J. Org. Chem. 2010, 6, 1-4.

[124] L. J. Gooßen, B. Melzer, J. Org. Chem. 2007, 72, 7473-7476.

[125] R. D. Larsen, A. O. King, C. Y. Chen, E. G. Corley, B. S. Foster, F. E. Roberts, C. Yang, D. R. Lieberman, R. A. Reamer, D. M. Tschaen, T. R. Verhoeven, P. J. Reider, J. Org. Chem. 1994, 59, 6391-6394.

[126] J. Li, L. Ackermann, Chem. Eur. J. 2015, 21, 5718-5722.

[127] S. Aalla, G. Gilla, Y. Bojja, R. R. Anumula, P. R. Vummenthala, P. R. Padi, Org. Process Res. Dev. 2012, 16, 682-686.

[128] G.-X. Wang, B.-P. Sun, C.-H. Peng, Org. Process Res. Dev. 2011, 15, 986-988.

[129] S. Kumar, S. B. Reddy, B. K. Sinha, K. Mukkanti, R. Dandala, Org. Process Res. Dev. 2009, 13, 1185-1189.

[130] U. Beutler, M. Boehm, P. C. Fuenfschilling, T. Heinz, J.-P. Mutz, U. Onken, M. Mueller, W. Zaugg, Org. Process Res. Dev. 2007, 11, 892-898.

[131] D. Zell, S. Warratz, D. Gelman, S. J. Garden, L. Ackermann, Chem. Eur. J. 2016, 22, $1248-1252$.

[132] S. D. Sarkar, W. Liu, S. I. Kozhushkov, L. Ackermann, Adv. Synth. Catal. 2014, 356, 1461-1479.

[133] V. S. Thirunavukkarasu, S. I. Kozhushkov, L. Ackermann, Chem. Commun. 2014, 50, 29-39.

[134] R. Manikandan, M. Jeganmohan, Org. Lett. 2014, 16, 3568-3571.

[135] R. Manikandan, M. Jeganmohan, Org. Lett. 2014, 16, 912-915.

[136] X. Yang, G. Shan, Y. Rao, Org. Lett. 2013, 15, 2334-2337.

[137] G. Pratsch, T. Wallaschkowski, M. R. Heinrich, Chem. Eur. J. 2012, 18, 11555-11559.

[138] H. Jasch, J. Scheumann, M. R. Heinrich, J. Org. Chem. 2012, 77, 10699-10706.

[139] A. Wetzel, V. Ehrhardt, M. R. Heinrich, Angew. Chem. Int. Ed. 2008, 47, 9130-9133.

[140] K. Kitazawa, T. Kochi, M. Sato, F. Kakiuchi, Org. Lett. 2009, 11, 1951-1954.

[141] F. Kakiuchi, T. Kochi, Synthesis 2008, 3013-3039.

[142] G. A. Molander, N. Ellis, Acc. Chem. Res. 2007, 40, 275-286.

[143] M. Butters, J. N. Harvey, J. Jover, A. J. J. Lennox, G. C. Lloyd-Jones, P. M. Murray, Angew. Chem. Int. Ed. 2010, 49, 5156-5160. 
[144] M. Pucheault, S. Darses, J.-P. Genet, J. Am. Chem. Soc. 2004, 126, 15356-15357.

[145] S. Yanagisawa, K. Ueda, T. Taniguchi, K. Itami, Org. Lett. 2008, 10, 4673-4676.

[146] L. Ackermann, R. Vicente, H. K. Potukuchi, V. Pirovano, Org. Lett. 2010, 12, $5032-5035$.

[147] T. Schabel, C. Belger, B. Plietker, Org. Lett. 2013, 15, 2858-2861.

[148] R. V. Jagadeesh, G. Wienhöfer, F. A. Westerhaus, A.-E. Surkus, H. Junge, K. Junge, M. Beller, Chem. Eur. J. 2011, 17, 14375-14379.

[149] S. Chandrappa, K. Vinaya, T. Ramakrishnappa, K. S. Rangappa, Synlett 2010, 3019-3022.

[150] S. Gowda, K. Abiraj, D. C. Gowda, Tetrahedron Lett. 2002, 43, 1329-1331.

[151] S. K. Mohapatra, S. U. Sonavane, R. V. Jayaram, P. Selvam, Org. Lett. 2002, 4, $4297-4300$.

[152] L. P. Hammett, J. Am. Chem. Soc. 1937, 59, 96-103.

[153] C. Hansch, A. Leo, R. W. Taft, Chem. Rev. 1991, 91, 165-195.

[154] Y. Aihara, N. Chatani, Chem. Sci. 2013, 4, 664-670.

[155] J. Li, L. Ackermann, Angew. Chem. Int. Ed. 2015, 54, 3635-3638.

[156] Z. Ruan, S. Lackner, L. Ackermann, Angew. Chem. Int. Ed. 2016, 55, 3153-3157.

[157] J. Li, S. Warratz, D. Zell, S. D. Sarkar, E. E. Ishikawa, L. Ackermann, J. Am. Chem. Soc. 2015, 137, 13894-13901.

[158] B.-F. Shi, N. Maugel, Y.-H. Zhang, J.-Q. Yu, Angew. Chem. Int. Ed. 2008, 47, $4882-4886$.

[159] G.-J. Cheng, P. Chen, T.-Y. Sun, X. Zhang, J.-Q. Yu, Y.-D. Wu, Chem. Eur. J. 2015, $21,11180-11188$

[160] M. Lafrance, K. Fagnou, J. Am. Chem. Soc. 2006, 128, 16496-16497.

[161] C.-J. Li, Chem. Rev. 2005, 105, 3095-3165.

[162] X. Tian, F. Yang, D. Rasina, M. Bauer, S. Warratz, F. Ferlin, L. Vaccaro, L. Ackermann, Chem. Commun. 2016, 52, 9777-9780.

[163] (a) J. Hubrich, T. Himmler, L. Rodefeld, L. Ackermann, Adv. Synth. Catal. 2015, 357, 474-480; (b) During the course of our work, a related report on ruthenium(II)catalyzed $\mathrm{C}-\mathrm{H}$ arylation of anilides in THF as solvent was published, see: R. K. Chinnagolla, M. Jeganmohan, Chem. Commun. 2014, 50, 2442-2444.

[164] J. Hubrich, T. Himmler, L. Rodefeld, L. Ackermann, ACS Catal. 2015, 5, 4089-4093.

[165] J. Hubrich, L. Ackermann, Eur. J. Org. Chem. 2016, 3700-3704.

[166] H. E. Gottlieb, V. Kotlyar, A. Nudelman, J. Org. Chem. 1997, 62, 7512-7515. 
[167] L. Ackermann, L. Wang, R. Wolfram, A. V. Lygin, Org. Lett. 2012, 14, 728-731.

[168] C. Zhang, N. Jiao, Angew. Chem. Int. Ed. 2010, 49, 6174-6177.

[169] Y. Lian, R. G. Bergman, L. D. Lavis, J. A. Ellman, J. Am. Chem. Soc. 2013, 135, $7122-7125$.

[170] J. J. Mousseau, F. Vallèe, M. M. Lorion, A. B. Charette, J. Am. Chem. Soc. 2010, 132, $14412-14414$.

[171] S.-C. Zhao, X.-Z. Shu, K.-G. Ji, A.-X. Zhou, T. He, X.-Y. Liu, Y.-M. Liang, J. Org. Chem. 2011, 76, 1941-1944.

[172] B. S. Kim, C. Jang, D. J. Lee, S. W. Youn, Chem. Asian J. 2010, 5, 2336-2340.

[173] J. Xi, Q.-L. Dong, G.-S. Liu, S. Wang, L. Chen, Z.-J. Yao, Synlett 2010, 11, 16741678. 



\section{Danksagung}

Ausdrücklich bedanken möchte ich mich an erster Stelle bei Herrn Prof. Dr. Lutz Ackermann für die höchst interessante Themenstellung und die hervorragende fachliche Beratung, sowie für die freundliche Betreuung während dieser Arbeit.

Herrn Dr. Alexander Breder danke ich für die bereitwillige Übernahme des Zweitgutachtens, sowie den weiteren Mitgliedern der Prüfungskommission Prof. Dr. Manuel Alcarazo, Prof. Dr. Dietmar Stalke, Dr. Shoubhik Das und Dr. Franziska Thomas.

Darüber hinaus möchte ich mich für die exzellente Kooperation mit Bayer CropScience bedanken, insbesondere Herrn Dr. Thomas Himmler für die gute Zusammenarbeit.

Für das sorgfältige Korrekturlesen dieser Arbeit bedanke ich mich bei Dr. Alan James Reay, Daniel Zell, Dr. Gianpiero Cera, Thomas Müller, Joachim Loup und Torben Rogge.

Gabi danke ich für die freundliche Unterstützung bei administrativen und organisatorischen Angelegenheiten. Bei Karsten und Stefan bedanke ich mich für die vielen Kleinigkeiten, wie die Trennung verkeilter Glasgeräte, die Trocknung von Lösungsmitteln, die Beschaffung neuer Arbeitsgeräte, Chemikalien und vieles mehr.

Ein großes Dankeschön gilt gegenwärtigen als auch ehemaligen Mitgliedern des Arbeitskreises für das kollegiale Arbeitsklima, besonders Labor 309 für die gute Zusammenarbeit und die gute Atmosphäre.

Zuletzt möchte ich mich ganz herzlich bei meinen Freunden und vor allem bei meiner Familie bedanken, die mir in der ganzen Zeit viel Rückhalt gegeben haben. Speziell möchte ich meiner Freundin Vanessa für Ihre liebevolle Art danken, ein wundervoller Mensch in meinem Leben. 



\section{Curriculum Vitae}

\section{Persönliche Daten}

\begin{tabular}{ll}
\hline Vor- und Nachname: & Jonathan Hubrich \\
Geburtsdatum und -ort: & 15.10 .1986 in Bremen \\
Staatsangehörigkeit: & Deutsch
\end{tabular}

Akademische Ausbildung

11/2012-09/2016 Promotionsstudium der Chemie, Georg-August-Universität Göttingen

Dissertation „Ruthenium(II)-Catalyzed C-H Arylations of Arenes" unter der Leitung von Prof. Dr. Lutz Ackermann in Kooperation mit Bayer CropScience, Georg-August-Universität Göttingen

04/2011-11/2012 Master of Science in Chemie, Georg-August-Universität Göttingen (Gesamtnote: ,sehr gut ${ }^{\text {ee }}$ )

Masterarbeit „Ruthenium-Catalyzed Oxidative $\mathrm{C}-\mathrm{O}$ Bond Formation through $\mathrm{C}-\mathrm{H}$ Bond Cleavage", unter der Leitung von Prof. Dr. Lutz Ackermann (Note: ,sehr gut ${ }^{\mathrm{ee}}$ )

10/2007-02/2011 Bachelor of Science in Chemie, Georg-August-Universität Göttingen (Gesamtnote: ,gut ${ }^{\mathrm{e}}$ )

Bachelorarbeit ,, Synthese luftstabiler Sulfonate für katalytische direkte Arylierungen elektronenarmer Heterocyclen", unter der Leitung von Prof. Dr. Lutz. Ackermann (Note: „,sehr gut ${ }^{\mathrm{ee}}$ )

Wehrdienst

10/2006-06/2007 Grundwehrdienst im Heer in Lingen (Ems) und Lohheide (Leistungsabzeichen der Bundeswehr in Gold)

Schulische Ausbildung

$06 / 2006$

Abitur (Leistungskurse: Chemie, Mathematik)

$08 / 2001-07 / 2006$

Gymnasium „Lessing Gymnasium”, Uelzen

\section{Lehr- und Betreuungstätigkeit}

11/2012-09/2016 Tutor an der Georg-August-Universität Göttingen für die Organisation von Seminaren und praktischen Laborkursen. Verantwortlich für die Sicherheit und gute Laborpraxis im Großraumlabor. Betreuung von Bachelor- und Masterarbeiten. 


\section{Publikationen}

J. Hubrich, L. Ackermann, Eur. J. Org. Chem. 2016, 3700-3704.

J. Hubrich, T. Himmler, L. Rodefeld, L. Ackermann, ACS Catal. 2015, 5, 4089-4093.

J. Hubrich, T. Himmler, L. Rodefeld, L. Ackermann, Adv. Synth. Catal. 2015, 357, 474-480.

V. S. Thirunavukkarasu, J. Hubrich, L. Ackermann, Org. Lett. 2012, 14, 4210-4213.

\section{Patente}

T. Himmler, L. Rodefeld, J. Hubrich, L. Ackermann ,,Method for producing biphenylamines from azobenzoles by ruthenium catalysis" WO 2016071249 A1 20160512, 2016.

T. Himmler, L. Rodefeld, J. Hubrich, L. Ackermann, „Method for the production of biphenylamines from azobenzenes using ruthenium catalysis" EP 3015452 A1 20160504, 2016.

T. Himmler, L. Rodefeld, J. Hubrich, L. Ackermann, ,, Method for producing biphenylamines from anilides by ruthenium catalysis" WO 2015162144 A1 20151029, 2015.

\section{Konferenzen und Posterpräsentationen}

01/07/2015

$12 / 06 / 2015$

$16-17 / 10 / 2014$

$28-30 / 09 / 2014$

$28 / 06 / 2013$
Göttinger Chemie-Forum 2015, Göttingen

Heidelberg Forum of Molecular Catalysis, Heidelberg

Niedersächsisches Katalyse Symposium, Göttingen

Sustainability in Chemistry, Erlangen

Heidelberg Forum of Molecular Catalysis, Heidelberg

\section{Sprachen}

Muttersprache: Deutsch

Fremdsprachen: $\quad$ Englisch fließend in Wort und Schrift

Französisch 